\section{Pacific Northwest}

National Laboratory

Operated by Battelle for the

U.S. Department of Energy

\title{
Characterization of Direct Push Vadose Zone Sediments from the T and TY Waste Management Areas
}
C. F. Brown
K. N. Geiszler
M. M. Valenta
E. T. Clayton
R. J. Serne
I. V. Kutnyakov
B. N. Bjornstad
S. R. Baum
D. C. Lanigan
M. J. Lindberg
C. Iovin
R. D. Orr
R. E. Clayton

June 2007

Prepared for the U.S. Department of Energy under Contract DE-AC05-76RL01830 


\title{
DISCLAIMER
}

This report was prepared as an account of work sponsored by an agency of the United States Government. Neither the United States Government nor any agency thereof, nor Battelle Memorial Institute, nor any of their employees, makes any warranty, express or implied, or assumes any legal liability or responsibility for the accuracy, completeness, or usefulness of any information, apparatus, product, or process disclosed, or represents that its use would not infringe privately owned rights. Reference herein to any specific commercial product, process, or service by trade name, trademark, manufacturer, or otherwise does not necessarily constitute or imply its endorsement, recommendation, or favoring by the United States Government or any agency thereof, or Battelle Memorial Institute. The views and opinions of authors expressed herein do not necessarily state or reflect those of the United States Government or any agency thereof.

\author{
PACIFIC NORTHWEST NATIONAL LABORATORY \\ operated by \\ BATTELLE \\ for the \\ UNITED STATES DEPARTMENT OF ENERGY \\ under Contract DE-AC05-76RL01830
}

Printed in the United States of America

Available to DOE and DOE contractors from the

Office of Scientific and Technical Information,

P.O. Box 62, Oak Ridge, TN 37831-0062;

ph: (865) 576-8401

fax: (865) 576-5728

email: reports@adonis.osti.gov

\author{
Available to the public from the National Technical Information Service, \\ U.S. Department of Commerce, 5285 Port Royal Rd., Springfield, VA 22161 \\ ph: (800) 553-6847 \\ fax: $(703) 605-6900$ \\ email: orders@ntis.fedworld.gov \\ online ordering: http://www.ntis.gov/ordering.htm
}

This document was printed on recycled paper.

(9/2003) 
PNNL-16649

\section{Characterization of Vadose Zone Sediments from the $T$ and TY Waste Management Areas}
C. F. Brown
K. N. Geiszler
M. M. Valenta
E. T. Clayton
R. J. Serne
I. V. Kutnyakov
B. N. Bjornstad
S. R. Baum
D. C. Lanigan
M. J. Lindberg
C Iovin
R. D. Orr
R. E. Clayton

June 2007

Prepared for CH2M HILL Hanford Group, Inc. and the U.S. Department of Energy under Contract DE-AC05-76RL01830

Pacific Northwest National Laboratory

Richland, Washington 99352 



\section{Executive Summary}

The overall goals of the Tank Farm Vadose Zone Project, led by CH2M HILL Hanford Group, Inc., are: 1) to define risks from past and future single-shell tank farm activities, 2) to identify and evaluate the efficacy of interim measures, and 3) to aid, via collection of geochemical information and data, the future decisions that must be made by the U.S. Department of Energy (DOE) regarding the near-term operations, future waste retrieval, and final closure activities for the single-shell tank Waste Management Areas (WMAs). For a more complete discussion of the goals of the Tank Farm Vadose Zone Project, see the overall work plan, Phase 1 RCRA Facility Investigation/Corrective Measures Study Work Plan for the Single-Shell Tank Waste Management Areas (DOE 1999). Specific details on the rationale for activities performed at WMAs T and TX-TY are found in Crumpler (2002). To meet these goals, CH2M HILL Hanford Group, Inc., asked scientists from Pacific Northwest National Laboratory (PNNL) to perform detailed analyses of vadose zone sediment collected within the T and TY Tank Farms. Specifically, this report contains all the geologic, geochemical, and selected physicochemical characterization data compiled on vadose zone sediment recovered from direct push samples collected near tanks 241-TY-105 and 241-TY-106 in the TY single-shell tank farm and near tanks 241-T-101 and 241-T-104 in the T single-shell tank farm. Additionally, this report compiles data from direct push samples collected north of the T Tank Farm in support of interim measures.

A geochemical investigation in the vicinity of tanks 241-TY-105 and 241-TY-106 was performed using pairs of direct push probe holes. A total of 31 direct pushes were driven within the TY Tank Farm; 25 of these holes were logged for moisture, gross gamma, and spectral gamma using calibrated probes and six were driven for the purpose of retrieving vadose zone sediment for characterization and analysis. The samples were collected around tank 241-TY-105, which was estimated to have leaked 35,000 gal of tributyl phosphate (TBP) waste (UPR-200-W-152) from the uranium recovery process to the vadose zone in 1960 (Wood et al. 2001), and tank 241-TY-106, which was estimated to have leaked 20,000 gal of TBP-uranium recovery waste to the vadose zone in 1959 (UPR-W-153).

Additionally, this report contains all the geochemical and selected physical characterization data collected on vadose zone sediment recovered from seven direct push characterization holes emplaced to investigate vadose zone contamination associated with an leak from tank 241-T-101. Deaton (DOE 1992) postulated that a leak from tank 241-T-101 resulted in a loss of 28,390 liters (7,500 gallons) of tank waste to the subsurface. This event was the basis for placing tank 241-T-101 on the list of assumed/known leakers. It has been estimated that $1230 \mathrm{Ci}$ of cesium-137, $0.0434 \mathrm{Ci}$ of cobalt- 60 , and $0.382 \mathrm{Ci}$ of technetium-99 were lost to the vadose zone as a result of the 1992 leak event (Wood et al. 2001).

A total of 19 probe holes were emplaced around tanks 241-T-101 and 241-T-104. Fourteen of these holes were logged for moisture, gross gamma, and spectral gamma using calibrated probes. A zone or depth of interest was identified for sampling in each probe hole based on neutron moisture logging data. Once an appropriate sampling depth was identified, a second hole was pushed as close as possible to the logged hole for collection of 1.5 feet of core material at the depth of interest. Due to lack of contaminants found during logging, field limitations, and poor sample recoveries, only five holes were successfully driven for the purpose of collecting vadose zone sediment samples. 
A core log was generated for both sets of samples ( $\mathrm{T}$ and TY direct push campaigns, respectively) and a visual geologic evaluation of all sediment samples was performed at the time of liner processing. Aliquots of sediment from the liners were analyzed and characterized in the laboratory for the following parameters: moisture content, gamma-emitting radionuclides, one-to-one sediment:water extracts (which provided soil $\mathrm{pH}$, electrical conductivity, cation, trace metal, and anion data), total carbon and inorganic carbon content, and $8 \mathrm{M}$ nitric acid leaches (which provided a measure of the total leachable contaminant content in the sediment). Two key radioactive contaminants, technetium-99 and uranium-238, along with other trace metals, were determined in acid and water extracts using inductively coupled plasma-mass spectrometry (ICP-MS). All of the parameters were elevated in at least some of the samples analyzed as part of this study.

The distribution of the water-extractable major cations in the direct push sediment samples indicates that an ion-exchange process dominates the pore water/sediment interactions where tank fluid has passed by or currently exists. The depth profiles for the divalent alkaline earth cations (calcium, magnesium, and strontium) versus sodium show depleted alkaline earth cation concentrations in the shallow Hanford formation sediments at both locations to depths of up to $80 \mathrm{ft} \mathrm{bgs}$ (the terminal depth of the deepest samples collected). Conversely, the water-extractable sodium concentrations in these zones were elevated. These trends suggest that tank fluids that are high in sodium are present at these locations. The lack of a significant amount of nitrate in the TY Tank Farm direct push holes indicates that the contamination has been present for a sufficiently long period of time to facilitate the migration of more mobile contaminants (i.e., nitrate and technetium-99) deeper into the vadose zone. The observance of significantly elevated nitrate in the deepest direct push samples collected as part of the T Tank Farm campaign further support the premise that mobile contaminants reside much deeper in the vadose zone at both of these locations.

After evaluating all the characterization and analytical data, there is no question that the vadose zone surrounding tank 241-TY-106 has been contaminated by tank-related waste. The direct observance of elevated soil $\mathrm{pH}$ and cesium-137 in close proximity to tank 241-TY-106 indicates that the tank or infrastructure associated with the tank is responsible for the contamination. The poor sediment recovery associated with the direct push technique has made it difficult to estimate the lateral spread of the contamination, while the capabilities of the direct push technique has made it impossible to determine the vertical extent of the contamination. However, based on characterization of the three probe holes that were emplaced south of tank 241-TY-106, it does not appear that a significant amount of lateral migration has occurred at the depths sampled. Interpretation of the water extract data associated with these samples indicates that the mobile constituents associated with this leak event reside deeper in the vadose zone at this location; however, the lack of depth-discrete samples does not enable the confirmation of this hypothesis.

The vadose zone south tank 241-TY-105 has also been affected by a tank-related waste solution. The presence of sodium as the dominant water-extractable cation indicates that a high sodium-bearing waste stream has created a cation exchange front in this region that has pushed the prominent divalent cations (calcium and magnesium) off the surface exchange sites on the sediment. The lack of 1) elevated soil $\mathrm{pH}$ or 2) detection of gamma-emitting radionuclides indicates that the point source of contamination is not in the direct vicinity of the only sample probe hole emplaced near tank 241-TY-105. The lack of direct evidence of a point source waste signature near tank 241-TY-105 does not mean that the tank did not leak; rather, the vadose zone sediment collected as part of this investigation was not sufficient to either confirm or rebut the supposition that a leak from tank 241-TY-105 led to UPR 200-W-152. 
After evaluating all the characterization and analytical data associated with the T Tank Farm direct push campaign, there is no question that the vadose zone in the vicinity of tank 241-T-101 has been contaminated by tank-related waste. The direct observance of elevated soil $\mathrm{pH}$, porewater-corrected electrical conductivity, nitrate, technetium-99, elevated water-extractable sodium, and fission product isotopes of europium as well as cesium-137 in close proximity to tank 241-T-101 indicate that the tank or infrastructure associated with the tank is responsible for the contamination. The sparse sample coverage associated with the direct push technique has made it difficult to estimate the lateral spread of the contamination, while the nature of the direct push technique has made it impossible to determine the vertical extent of the contamination. However, based on characterization of the probe holes that were emplaced to the southeast of tank 241-T-101, it appears that waste from tank 241-T-101 migrated laterally several meters away from the tank. Interpretation of the water extract data associated with these samples indicates that the mobile constituents associated with this leak event reside deeper in the vadose zone at this location; however, the lack of depth-discrete samples does not enable the confirmation of this hypothesis.

The vadose zone directly northeast of tank 241-T-104 also has been found to be contaminated with tank waste constituents. It is not possible at this time to directly attribute the source of this contamination to a particular tank. Sufficient data does not exist to determine if the contamination observed in this region is a result of a loss from tank 241-T-104 or if it is a result of lateral spreading of waste from tank 241-T-101. 



\section{Acknowledgements}

This work was conducted as part of the Tank Farm Vadose Zone Project led by CH2M HILL Hanford Group, Inc., in support of the U.S. Department of Energy (DOE)'s Office of River Protection. The authors wish to thank John G. Kristofzski, Frank J. Anderson, Fredrick M. Mann, David A. Myers, Michael P. Connelly, and Harold A. Sydnor with CH2M HILL Hanford Group, Inc. and Dwayne Crumpler with Columbia Energy and Environmental Services for their planning support and technical review of this work, and Marcus I. Wood with Fluor Hanford, Inc., and Bill Deutsch and Wooyong Um, both with Pacific Northwest National Laboratory (PNNL), for their technical review of the report. We would also like to express our gratitude to Robert Lober with the DOE Office of River Protection for his support and interest.

We would especially like to thank Kent D. Reynolds, Dave Skoglie, Kelly Olson, and Mark Repko (Duratek Federal Services, Inc.) for their efforts in selecting depths to sample and executing the field work that obtained the samples.

Finally, the authors would also like to thank Theresa Gilbride (PNNL) for completing the editorial review (PNNL) and Michael Parker (PNNL) for the final formatting of this technical report. 



\section{Contents}

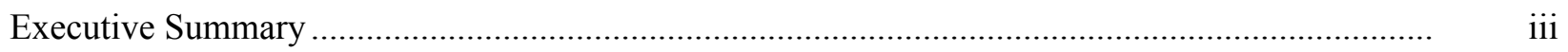

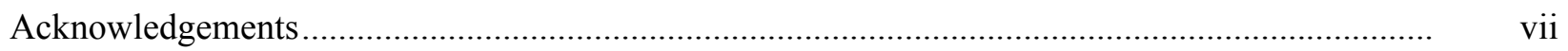

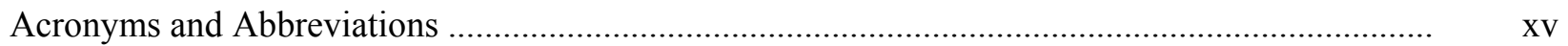

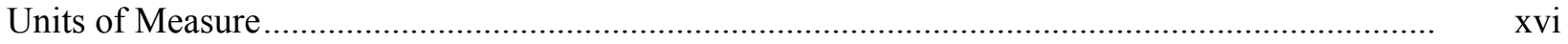

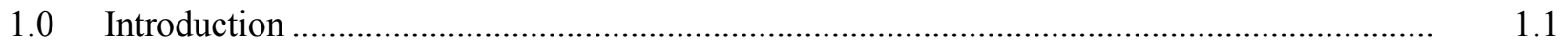

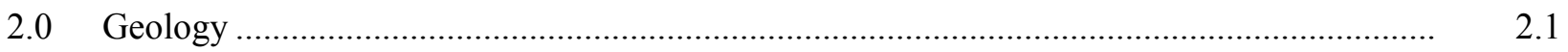

2.1 Characterization and Sampling Methods................................................................. 2.6

2.2 Interpreted Geology Related to Direct-Push Samples .............................................. 2.12

3.0 Geochemical Methods and Materials …........................................................................... 3.1

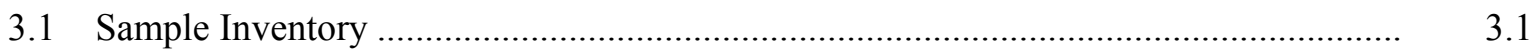

3.1.1 TY Tank Farm Direct Push Samples.......................................................... 3.1

3.1.2 T Tank Farm Direct Push Samples................................................................ 3.1

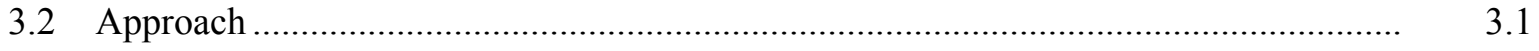

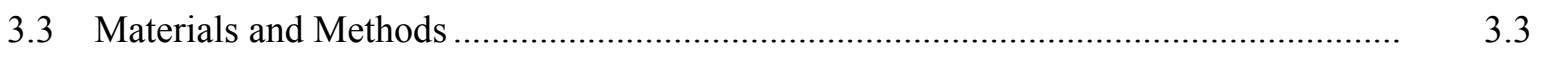

3.3.1 Moisture Content ..................................................................................... 3.3

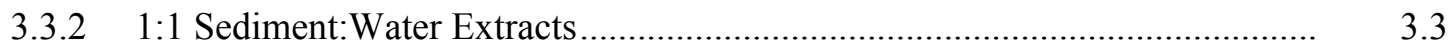

3.3.3 Technetium-99 Extraction and Analysis ..................................................... $\quad 3.5$

3.3.4 Stable Ruthenium Analysis ..................................................................... 3.6

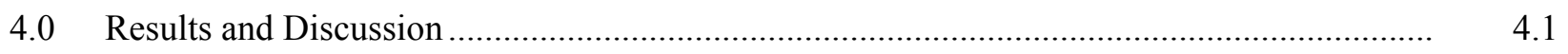

4.1 Vadose Zone Sediment from the TY Tank Farm Direct Push Samples ........................

4.1.1 Moisture Content................................................................................. 4.1

4.1.2 1:1 Sediment:Water Extracts................................................................. $\quad 4.2$

4.1.3 Vadose Zone Porewater Chemical Composition............................................. 4.11

4.1.4 8 M Nitric Acid-Extractable Amounts of Selected Elements in the TY Tank Farm Direct Push Sediments .................................................................... 4.18

4.1.5 Radionuclide Content in Vadose Zone Sediment from the TY Tank Farm Direct Push Holes ...................................................................................... $\quad 4.20$

4.1.6 Total Carbon, Calcium Carbonate, and Organic Carbon Content of Vadose Zone Sediment from the TY Tank Farm Direct Push Holes ............................ 4.22

4.2 Vadose Zone Sediment from the T Tank Farm Direct Push Samples............................ 4.22

4.2.1 Moisture Content ............................................................................................... $\quad 4.22$

4.2.2 1:1 Sediment:Water Extracts................................................................... 4.22

4.2.3 Vadose Zone Porewater Chemical Composition............................................ 4.37

4.2.4 8 M Nitric Acid-Extractable Amounts of Selected Elements in the TY Tank Farm Direct Push Sediments ......................................................................... 4.42

4.2.5 Radionuclide Content in Vadose Zone Sediment from the TY Tank Farm Direct Push Holes ....................................................................................... 4.46

4.2.6 Total Carbon, Calcium Carbonate, and Organic Carbon Content of Vadose Zone Sediment from the TY Tank Farm Direct Push Holes... 
4.3 Tier II Sample Investigations ………………………………………………….... 4.49

4.3.1 Technetium-99 Extraction and Analysis ....................................................... $\quad 4.50$

4.3.2 Stable Ruthenium Isotopic Analysis .............................................................. $\quad 4.55$

4.3.3 Estimating Recharge Using 1:1 Sediment:Water Extract Chloride Data .......... 4.61

5.0 Summary and Observations...............................................................................................

5.1 T and TX-TY Tank Farms Physical Geology Model .................................................... 5.1

5.2 TY Tank Farm Characterization Activities and Data.................................................. 5.1

5.2.1 Sampling Summary at the TY Tank Farm .................................................... 5.1

5.2.2 Moisture Content.................................................................................... 5.2

5.2.3 Contamination Profile around tanks 241-TY-105 and 241-TY-106 ................. 5.2

5.2.4 Source of Contamination around Tanks 241-TY-105 and 241-TY-106 ........... 5.3

5.3 T Tank Farm Characterization Activities and Data...................................................... 5.4

5.3.1 Sampling Summary at the T Tank Farm .................................................... 5.4

5.3.2 Moisture Content .................................................................................... 5.4

5.3.3 Contamination Profile around Tank 241-T-101 ……………………………... $\quad 5.5$

5.3.4 Tier II Activites Associated with the T Tank Farm Direct Push Samples ........ $\quad 5.6$

5.3.5 Source of Contamination around tanks 241-T-101 and 241-T-104 .................. 5.9

5.4 Detailed Characterization to Elucidate Controlling Geochemical Processes at the

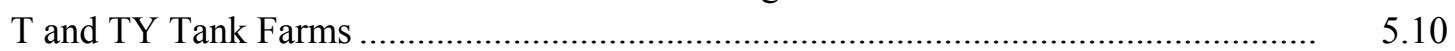

$6.0 \quad$ Interim Measures Support ...............................................................................................

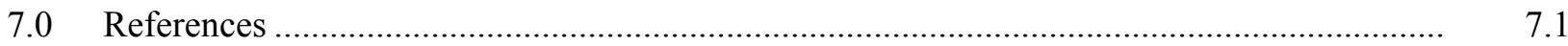

Appendix A - Photographs of Core and Grab Samples from the Direct Push Boreholes in the Vicinity of Single-Shell Tanks 241-TY-105 and 241-TY-106............................................ A.1

Appendix B - Logs of Core and Grab Samples from the Direct Push Boreholes in the Vicinity of Single-Shell Tanks 241-TY-105 and 241-TY-106

Appendix C - Photographs of Core and Grab Samples from the Direct Push Boreholes in the Vicinity of Single Shell Tanks 241-T-101 and 241-T-104.

Appendix D - Logs of Core and Grab Samples from the Direct Push Boreholes in the Vicinity of Single Shell Tanks 241-T-101 and 241-T-104 ............................................................. D.1

Appendix E - Photographs of Core and Grab Samples from the Interim Measures Direct Push Boreholes Collected North of the T Tank Farm .................................................................. E. E.1

Appendix F - Logs of Core and Grab Samples from the Interim Measures Direct Push Boreholes Emplaced North of the T Tank Farm............................................................................. F. F.

\section{Figures}

2.1 Generalized, Composite Stratigraphy for the Late-Cenozoic Sediments Overlying the Columbia River Basalt Group at the T-TY Tank Farm..

2.2 Borehole and Cross Section Location Map..

2.3 Hydrogeologic Cross Section Through the T and TY Tank Farms......................................... 2.5

2.4 Locations of Direct Push holes in Vicinity of the T Tank Farm .............................................. 2.7

2.5 Locations of Direct-Push holes in Vicinity of the TY Tank Farm .......................................... 2.8 
4.1 Moisture Content Data for the TY Tank Farm Direct Push Samples......

4.2 pH for 1:1 Sediment:Water Extracts and Dilution-Corrected EC Values from TY Tank Farm

4.3 1:1 Sediment:Water-Extractable Nitrate and Sulfate Data from the TY Tank Farm Direct Push Samples

4.4 1:1 Sediment:Water-Extractable Chloride and Fluoride Data from the TY Tank Farm Direct Push Samples

4.5 1:1 Sediment:Water-Extractable Sodium and Calcium Data from the TY Tank Farm Direct Push Samples

4.6 1:1 Sediment:Water-Extractable and 8M Nitric Acid Extractable Uranium-238 Data from the TY Tank Farm Direct Push Samples

4.7 1:1 Sediment:Water-Extractable Alkalinity Data from the TY Tank Farm Direct Push Samples

4.8 Gamma Energy Analysis Data from the TY Tank Farm Direct Push Samples .....................

4.9 Moisture Content Data for the T Tank Farm Direct Push Samples ......................................

$4.10 \mathrm{pH}$ for 1:1 Sediment:Water Extracts and Dilution-Corrected EC Values from T Tank Farm.

4.11 1:1 Sediment:Water-Extractable Nitrate and Sulfate data from the T Tank Farm Direct Push Samples

4.12 1:1 Sediment:Water-Extractable Chloride and Fluoride Data from the T Tank Farm Direct Push Samples

4.13 1:1 Sediment:Water-Extractable Sodium and Calcium data from the T Tank Farm Direct Push Samples

4.14 1:1 Sediment:Water-Extractable and 8M Nitric Acid Extractable Technetium-99 data from the T Tank Farm Direct Push Samples

4.15 1:1 Sediment:Water-Extractable and 8M Nitric Acid Extractable Uranium-238 data from the T Tank Farm Direct Push Samples.

4.16 1:1 Sediment:Water-Extractable Alkalinity Data from the T Tank Farm Direct Push Samples

4.17 Gamma Energy Analysis Data from the T Tank Farm Direct Push Samples .........................

4.18 Gamma Energy Analysis Data from the T Tank Farm Direct Push Samples

4.19 Ruthenium Isotopic Data from the T Tank Farm Direct Push Samples and Samples from Borehole C4104

4.20 Photograph of Fine-Grained Upper Cold Creek Unit Sediment Recovered from 81.0 to $81.5 \mathrm{ft}$ bgs in Probe Hole C5374

4.21 Photograph of Fine-Grained Upper Cold Creek Unit Sediment Recovered from 80.5 to $81.0 \mathrm{ft}$ bgs in Probe Hole C5374....

4.22 Photograph of Fine-Grained Upper Cold Creek Unit Sediment Recovered from 80.0 to $80.5 \mathrm{ft}$ bgs in Probe Hole C5374.

4.23 Photograph of Sediment Recovered from 75.1 to $75.7 \mathrm{ft}$ bgs in Borehole C4104 ................... 


\section{Tables}

2.1 Stratigraphic Terminology for the Vadose Zone Beneath T-TY Tank Farm ......................... 2.3

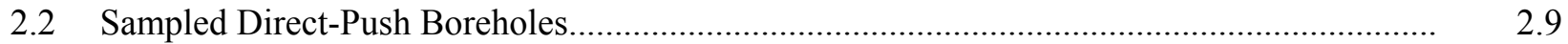

2.3 Analyzed Samples from the T and TY Tank Farms................................................................ 2.10

3.1 Sample Inventory from the TY Tank Farm Direct Push Probe Holes ................................... 3.2

3.2 Sample Inventory from the T Tank Farm Direct Push Probe Holes ..................................... 3.2

4.1 Gravimetric Moisture Content of Samples Obtained from the TY Tank Farm Direct Push Probe Holes

4.2 $\mathrm{pH}$ for 1:1 Sediment:Water Extracts and Dilution-Corrected EC Values from TY Tank Farm Core and Grab Samples .......................................................................................

4.3 Water-Extractable Anions in the TY Tank Farm Core and Grab Samples ........................... 4.6

4.4 Water-Extractable Major Cations in the TY Tank Farm Core and Grab Samples..................

4.5 Water-Extractable Cations in the TY Tank Farm Core and Grab Samples .......................... 4.11

4.6 Water-Extractable Mobile Metals in the TY Tank Farm Core and Grab Samples ................ 4.12

4.7 Calculated Pore Water Anion Concentrations in the TY Tank Farm Core and Grab Samples 4.15

4.8 Calculated Pore Water Cation Concentrations in the TY Tank Farm Direct Push Core and Grab Samples

4.9 Calculated Pore Water Metal Concentrations in the TY Tank Farm Direct Push Core and Grab Samples

4.10 Calculated Pore Water Mobile Metal Concentrations of Key Contaminants of Concern in the TY Tank Farm Direct Push Core and Grab Samples

4.11 Acid-Extractable Cations in the TY Tank Farm Direct Push Core and Grab Samples............

4.12 Acid-Leachable Cations in the TY Tank Farm Core and Grab Samples

4.13 Acid-Extractable Mobile Metals in the TY Tank Farm Direct Push Core and Grab Samples.

4.14 Gamma Emitting Radionuclides in the TY Tank Farm Direct Push Sediments ....................

4.15 Carbon Content of the TY Tank Farm Vadose Zone Samples.

4.20

4.23

4.16 Gravimetric Moisture Content of Samples Obtained from the T Tank Farm Direct Push Probe Holes

4.17 pH for 1:1 Sediment:Water Extracts and Dilution-Corrected EC Values from T Tank Farm Core and Grab Samples

4.18 Water-Extractable Anions in the T Tank Farm Core and Grab Samples

4.19 Water-Extractable Major Cations in the T Tank Farm Core and Grab Samples.....................

4.20 Water-Extractable Cations in the T Tank Farm Core and Grab Samples

4.21 Water-Extractable Mobile Metals in the T Tank Farm Core and Grab Samples .....................

4.34

4.22 Calculated Pore Water Anion Concentrations in the T Tank Farm Core and Grab Samples...

4.38

4.23 Calculated Pore Water Cation Concentrations in the T Tank Farm Direct Push Core and Grab Samples

4.24 Calculated Pore Water Mobile Metal Concentrations of Key Contaminants of Concern in the T Tank Farm Direct Push Core and Grab Samples

4.25 Acid-Extractable Cations in the T Tank Farm Direct Push Core and Grab Samples...............

4.26 Acid-Leachable Cations in the T Tank Farm Core Samples.....

4.27 Acid-Extractable Mobile Metals in the T Tank Farm Direct Push Core and Grab Samples ... 
4.30 Water Extractable Technetium-99 Concentrations in the T Tank Farm Vadose Zone Samples

4.31 Water Extractable Technetium-99 Concentrations in the T Tank Farm Vadose Zone Samples After Resin Treatment.

4.32 Acid Extractable Technetium-99 Concentrations in the T Tank Farm Vadose Zone

4.33 Acid Extractable Technetium-99 Concentrations in the T Tank Farm Vadose Zone After Resin Treatment

4.34 Microwave Digestible Technetium-99 Concentrations in the T Tank Farm Vadose Zone......

4.35 Microwave Digestible Technetium-99 Concentrations in the T Tank Farm Vadose Zone After Resin Treatment

5.1 Maximum Pore Water Concentrations in Sediments from the Hanford Formation Unit..........

6.1 Sample Inventory from the T Tank Farm Interim Measures Samples

6.2 Gravimetric Moisture Content of Samples Obtained from the T Tank Farm Interim Measures Activites

6.3 Sediment:Water Extractable Nitrate Data for Samples Obtained from the T Tank Farm Interim Measures Activities

6.4 1:1 Sediment:Water Extractable Technetium-99 Data for Samples Obtained from the $\mathrm{T}$ Tank Farm Interim Measures Activities . 



\section{Acronyms and Abbreviations}

\begin{tabular}{|c|c|}
\hline$\%$ RSD & percent relative standard deviation \\
\hline ASA & American Society of Agronomy \\
\hline ASTM & American Society for Testing and Materials \\
\hline bgs & below ground surface \\
\hline $\mathrm{CMB}$ & chloride mass balance \\
\hline DOE & U.S. Department of Energy \\
\hline $\mathrm{EC}$ & electrical conductivity \\
\hline EPA & U.S. Environmental Protection Agency \\
\hline GEA & gamma energy analysis \\
\hline H1 & Hanford formation - H1 unit \\
\hline $\mathrm{H} 2$ & Hanford formation $-\mathrm{H} 2$ unit \\
\hline $\mathrm{HCl}$ & hydrochloric acid \\
\hline $\mathrm{HF}$ & hydrofluoric acid \\
\hline $\mathrm{HNO}_{3}$ & nitric acid \\
\hline HPGe & high-purity germanium \\
\hline IC & ion chromatography or ion chromatograph \\
\hline ICP-MS & inductively coupled plasma-mass spectrometer \\
\hline ICP-OES & inductively coupled plasma-optical emission spectroscopy \\
\hline ILAW & Integrated Low Activity Waste \\
\hline $\mathrm{Kd}$ & distribution coefficient, or sorption partition coefficient, in units of $\mathrm{mL} / \mathrm{g}$ \\
\hline $\mathrm{MC}$ & moisture content \\
\hline MCL & maximum contamination level \\
\hline $\mathrm{mS}$ & millisiemen \\
\hline NDIR & non-dispersive infrared \\
\hline NIST & National Institute of Standards and Technology \\
\hline PNNL & Pacific Northwest National Laboratory \\
\hline QA & quality assurance \\
\hline QC & quality control \\
\hline RCRA & Resource Conservation and Recovery Act of 1976 \\
\hline REDOX & $\begin{array}{l}\text { Reduction Oxidation Process (the second fuel reprocessing process used at the Hanford } \\
\text { Site to extract plutonium) }\end{array}$ \\
\hline Rtf & Ringold Formation sand \\
\hline Rwi & Ringold fluvial gravel \\
\hline TBP & Tributyl phosphate \\
\hline UFA & unsaturated flow apparatus (ultracentrifuge for squeezing pore water out of sediment) \\
\hline UPR & unplanned release \\
\hline USGS & U.S. Geological Survey \\
\hline WMA & waste management area \\
\hline
\end{tabular}




\section{Units of Measure}

\begin{tabular}{|c|c|}
\hline$\%$ & percent \\
\hline $\mathrm{Bgs}$ & below ground surface \\
\hline${ }^{\circ} \mathrm{C}$ & temperature in degrees Celsius $\left.\left[\mathrm{T}\left({ }^{\circ} \mathrm{C}\right)=\mathrm{T}(\mathrm{K})-273.15\right)\right]$ \\
\hline $\mathrm{Ci}$ & curie \\
\hline $\mathrm{cm}$ & centimeter \\
\hline $\mathrm{ft}$ & foot \\
\hline g & gram \\
\hline $\mathrm{g}$ & acceleration due to gravity \\
\hline in. & inch \\
\hline$\mu$ & micro (prefix, 10-6) \\
\hline$\mu \mathrm{Ci}$ & microcurie \\
\hline$\mu \mathrm{eq}$ & microequivalent \\
\hline$\mu \mathrm{g}$ & microgram \\
\hline$\mu \mathrm{m}$ & micrometer \\
\hline $\mathrm{m}$ & meter \\
\hline M & molarity, $\mathrm{mol} / \mathrm{L}$ \\
\hline $\mathrm{meq} / \mathrm{L}$ & milli-equivalent per liter \\
\hline $\mathrm{mg}$ & milligram \\
\hline $\mathrm{mL}$ & milliliter \\
\hline $\mathrm{mm}$ & millimeter \\
\hline $\mathrm{mM}$ & millimolar \\
\hline $\mathrm{mN}$ & millinormal \\
\hline mol & mole \\
\hline $\mathrm{mS}$ & milliSiemen \\
\hline $\mathrm{N}$ & Normal \\
\hline $\mathrm{nCi}$ & nanocurie \\
\hline ng & nanogram \\
\hline $\mathrm{pCi}$ & picocurie \\
\hline wt $\%$ & weight percent \\
\hline
\end{tabular}




\subsection{Introduction}

The overall goals of the Tank Farm Vadose Zone Project, led by CH2M HILL Hanford Group, Inc., are 1) to define risks from past and future single-shell tank farm activities, 2) to identify and evaluate the efficacy of interim measures, and 3) to aid, via collection of geochemical information and data, the future decisions that must be made by the U.S. Department of Energy (DOE) regarding the near-term operations, future waste retrieval, and final closure activities for the single-shell tank Waste Management Areas (WMAs). For a more complete discussion of the goals of the Tank Farm Vadose Zone Project, see the overall work plan, Phase 1 RCRA Facility Investigation/Corrective Measures Study Work Plan for the Single-Shell Tank Waste Management Areas (DOE 1999). Specific details on the rationale for activities performed at WMAs T and TX-TY are found in Crumpler (2002). To meet these goals, CH2M HILL Hanford Group, Inc., asked scientists from Pacific Northwest National Laboratory (PNNL) to perform detailed analyses of vadose zone sediment collected within the T and TY Tank Farms (Serne et al. 2004a,b). Upon completion of these activities, additional sampling was performed in the T and TY Tank Farms to further investigate potential leak events.

This report contains all the geochemical and selected physical characterization data collected on vadose zone sediment recovered from five direct push characterization holes emplaced to investigate vadose zone contamination associated with leaks from tanks 241-TY-105 (UPR-200-W-152) and 241-TY-106 (UPR-200-W-153). Tank 241-TY-105 is estimated to have leaked 35,000 gal of tributyl phosphate (TBP) waste from the uranium recovery process to the vadose zone in 1960 (Wood et al. 2001). Wood et al. (2001) conceptualized the 241-TY-105 tank leak as having occurred either at the tank bottom or from a shallow depth somewhere in the vicinity of drywell 52-05-07. Cesium-137 contamination in drywell 52-05-07 occurred at a depth consistent with the bottom of tank 241-TY-105. Wood et al. (2001) and Myers (2005) estimated that the leaked fluid migrated horizontally to the north and southwest of tank 241-TY-105 once it had penetrated deeper than the tank bottom. Wood et al. (2001) further hypothesized that the waste could have flowed to the south, east, and southeast, but the lack of drywells in the region prevented confirmation of this migration pathway. Cobalt- 60 from the 241-TY-105 tank leak has migrated vertically at this location and was observed at concentrations in excess of $10 \mathrm{pCi} / \mathrm{g}$ at the bottom of drywell 52-03-06. Tank 241-TY-106 is estimated to have leaked 20,000 gal of TBP-uranium recovery waste to the vadose zone in 1959. Although several drywells in the vicinity of tank 241-TY-106 contain measurable quantities of cesium-137 and/or cobalt-60, their relatively low concentrations indicate that the contaminant inventory in the vadose zone around tank 241-TY-106 is quite small (Wood et al. 2001). A location map highlighting the area of interest is presented in Section 2 (Figure 2.1).

Additionally, this report contains all the geochemical and selected physical characterization data collected on vadose zone sediment recovered from seven direct push characterization holes emplaced to investigate vadose zone contamination associated with an overfill event and leak from tank 241-T-101. Deaton (DOE 1992) postulated that a leak from tank 241-T-101 occurred in 1992, resulting in a loss of 28,390 liters (7,500 gallons) of tank waste to the subsurface. This event was the basis for placing tank 241-T-101 on the list of assumed/known leakers. It has been estimated that $1230 \mathrm{Ci}$ of cesium-137, $0.0434 \mathrm{Ci}$ of cobalt-60, and $0.382 \mathrm{Ci}$ of technetium-99 were lost to the vadose zone as a result of the 1992 leak event (Wood et al. 2001). Wood et al. (2001) conceptualized the vadose zone contamination near tank 241-T-101 having occurred from leakage from a waste transfer or cascade line rather than a tank 
wall breach. Cesium-137 contamination in drywell 50-01-04 occurred at a depth beginning at approximately 25 feet below ground surface and extending intermittently to the terminus depth of the drywell (125 feet below ground surface). Wood et al. (2001) and Myers (2005) estimated that the leaked fluid migrated to the south and can be found in drywell 50-01-06. A location map highlighting the area of interest is presented in Section 2 (Figure 2.1).

This report is divided into sections that describe the geochemical characterization methods employed and the results of analysis of the T and TY Tank Farm direct push core samples. English units are used in this report for descriptions and discussions of drilling activities and samples because that is the system of units used by drillers to measure and report depths. To convert feet to meters, multiply by 0.3048 ; to convert inches to centimeters, multiply by 2.54 . The metric system is used in this report for all other purposes. 


\subsection{Geology}

The regional geologic setting and site-specific geology in the vicinity of the T-TX-TY Tank Farm has been covered extensively in a number of previous reports (Price and Fecht 1976; Brown et al. 1979;

Tallman et al. 1979; Last et al. 1989; Connelly et al. 1992; Freeman-Pollard et al. 1994; Wood et al. 2001; Lindsey et al. 2001; Williams et al. 2002; DOE/GJO 1998, 1999; Reidel and Chamness 2007).

In general, the geology of the vadose zone beneath the T and TY Tank Farms includes four stratigraphic units. From youngest to oldest these include 1) recent deposits of eolian sand or backfill material, 2) Ice-Age flood deposits of the Hanford formation, 3) the Cold Creek unit, formerly known as the Plio-Pleistocene unit (DOE 2002), and 4) the Ringold Formation. The varying character of these units is compared in Figure 2.1 and Table 2.1.

Figure 2.2 shows the location of T and TY Tank Farms where the direct-push samples reported in this document were collected. The general geology and stratigraphy of the T and TY Tank Farms is illustrated along cross section A-A’ (Figure 2.3).

Recent surficial deposits at the T and TY Tank Farms usually consist of a meter or less of recent windblown sand. In the Tank Farms there may be up to $50 \mathrm{ft}$ of backfill material used to bury and fill around the underground storage tanks (Figure 2.3). Below this is up to $80 \mathrm{ft}$ of mostly sand and gravel, deposited onto the giant Cold Creek bar, which formed during repeated Pleistocene cataclysmic floods (Bjornstad 2006). The upper part of the Hanford formation is dominated with gravel (H1 unit) while the lower part is predominantly sand (H2 unit), although there is a considerable amount of internal heterogeneity.

Beneath the Hanford formation is the Cold Creek unit, which consists of an upper fine sand to silt unit and a lower unit of variably cemented caliche, representing a buried paleosol sequence. Combined, the Cold Creek unit may be up to $40 \mathrm{ft}$ thick and its upper surface has a pronounced dip to the south. Below the Cold Creek unit is a discontinuous layer of Ringold Formation sand (Rtf) underlain by a thick sequence of variably cemented Ringold fluvial gravel (Rwi). 


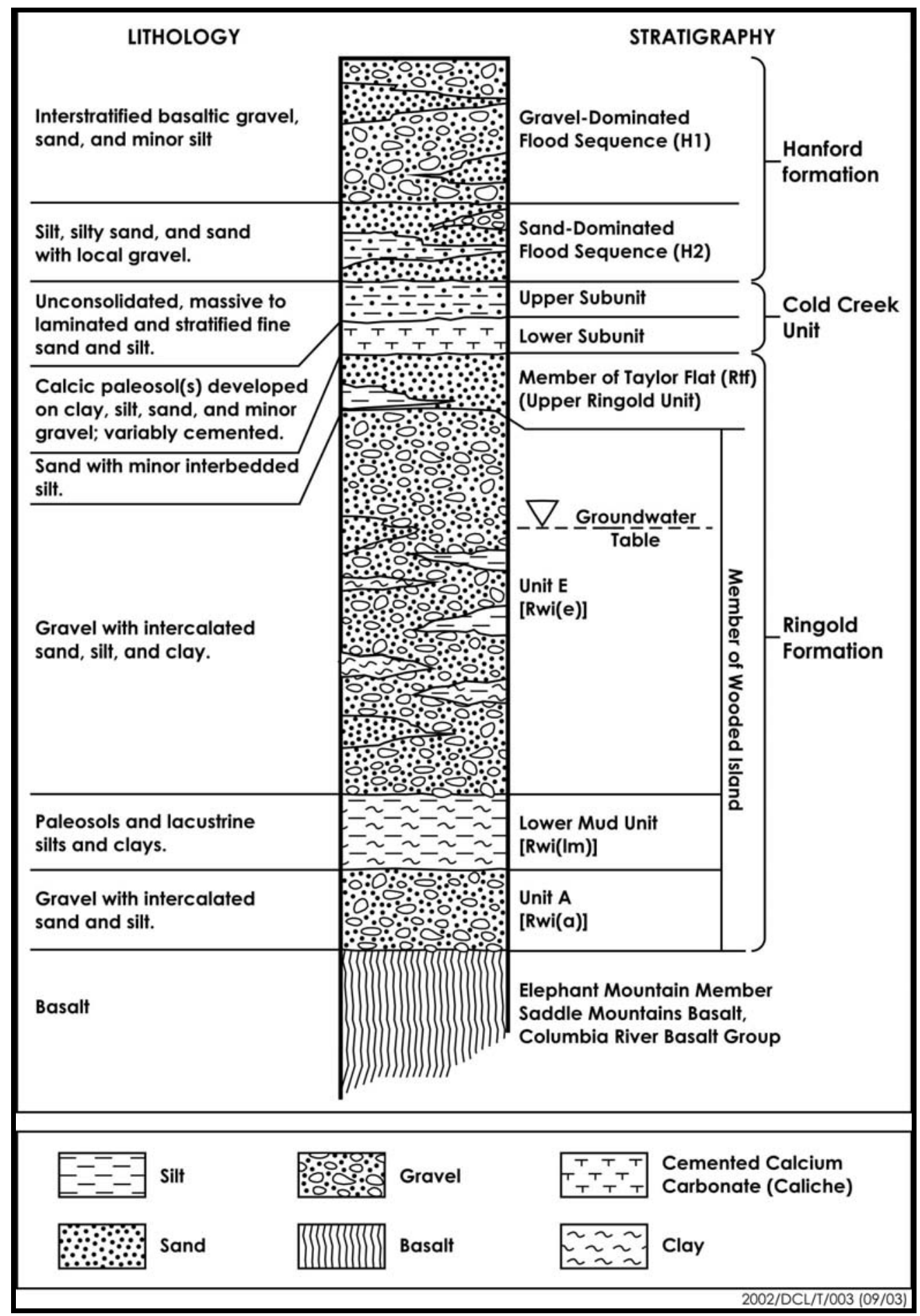

Figure 2.1. Generalized, Composite Stratigraphy for the Late-Cenozoic Sediments Overlying the Columbia River Basalt Group at the T-TY Tank Farm (modified after Wood et al. 2001) 
Table 2.1. Stratigraphic Terminology for the Vadose Zone Beneath T-TY Tank Farm

\begin{tabular}{|c|c|c|c|c|}
\hline $\begin{array}{c}\text { Stratigraphic } \\
\text { Symbol } \\
\end{array}$ & Formation & $\begin{array}{l}\text { Facies / } \\
\text { Subunit }\end{array}$ & Description & Genesis \\
\hline Backfill & NA & Backfill & $\begin{array}{l}\text { Gravel-dominated sequence consisting of poorly to } \\
\text { moderately sorted cobbles, pebbles, and coarse to } \\
\text { medium sand with some silt derived from coarse-grained } \\
\text { Hanford formation (H1 Unit) excavated around tanks } \\
\text { (Price and Fecht 1976; Wood et al. 2001). }\end{array}$ & Anthropogenic \\
\hline H1 & \multirow{2}{*}{$\begin{array}{l}\text { Hanford } \\
\text { formation }\end{array}$} & $\begin{array}{l}\text { Unit H1 } \\
\text { (Gravel- } \\
\text { dominated } \\
\text { facies } \\
\text { association) }\end{array}$ & $\begin{array}{l}\text { Gravel-dominated flood sequence composed of mostly } \\
\text { poorly sorted, basaltic, sandy gravel to silty sandy } \\
\text { gravel. Equivalent to the upper gravel sequence } \\
\text { discussed by Last et al. (1989), the Qfg documented by } \\
\text { Reidel and Fecht (1994), Hanford Gravel Unit A of } \\
\text { Johnson et al. (1999), coarse-grained sequence (H1 unit) } \\
\text { of Wood et al. (2001) and gravel facies of unit H1 of } \\
\text { Lindsey et al. (2001), and gravel-dominated facies } \\
\text { association of DOE (2002). The majority of this unit } \\
\text { was excavated out and is missing from beneath T Tank } \\
\text { Farm. }\end{array}$ & $\begin{array}{l}\text { Cataclysmic flood } \\
\text { deposits (high- } \\
\text { energy) }\end{array}$ \\
\hline H2 & & $\begin{array}{l}\text { Unit H2 (Sand- } \\
\text { dominated } \\
\text { facies } \\
\text { association) }\end{array}$ & $\begin{array}{l}\text { Sand-dominated flood sequence composed of mostly } \\
\text { horizontal to tabular cross-bedded sand to pebbly sand. } \\
\text { Some sand beds capped with thin layers of silty sand to } \\
\text { sandy silt. Equivalent to Hanford Sands of Johnson et } \\
\text { al. (1999), Fine-Grained Sequence (H2 unit) of Wood et } \\
\text { al. (2001) and unit H2 of Lindsey et al. (2001), the sandy } \\
\text { sequence of Last et al. (1989) and Lindsey et al. (1992), } \\
\text { and Qfs documented by Reidel and Fecht (1994), and } \\
\text { sand-dominated facies described in DOE (2002). The } \\
\text { H2 unit was subdivided into a lower and upper subunit } \\
\text { by Sobczyk (2001). }\end{array}$ & $\begin{array}{l}\text { Cataclysmic flood } \\
\text { deposits (moderate } \\
\text { energy) }\end{array}$ \\
\hline $\mathrm{CCU}_{\mathrm{u}}$ & \multirow{2}{*}{$\begin{array}{l}\text { Cold Creek } \\
\text { unit }\end{array}$} & $\begin{array}{l}\text { Upper } \\
\text { subunit }\end{array}$ & $\begin{array}{l}\text { Silty sequence consisting of massive to interstratified, } \\
\text { well sorted silt and fine sand. Uncemented but may be } \\
\text { moderately to strongly calcareous from detrital } \mathrm{CaCO}_{3} \text {. } \\
\text { Equivalent to the "early Palouse soil" (Brown 1970; } \\
\text { Tallman et al. 1979; DOE 1988; and DOE-GJO 1997) } \\
\text { and the Hanford Formation/Plio-Pleistocene deposits } \\
\text { (H/PP) of Wood et al. (2001). Also equivalent to the } \\
\text { upper Plio-Pleistocene unit (Lindsey et al. 2001; } \\
\text { Sobczyk 2001) and the fine-grained, laminated to } \\
\text { massive [CCUf(lam-msv)] lithofacies of the Cold Creek } \\
\text { unit (DOE 2002). Same as PPu of Lindsey et al. (2001). }\end{array}$ & $\begin{array}{l}\text { Post-Ringold Fm. } \\
\text { eolian and/or } \\
\text { overbank alluvial } \\
\text { deposits }\end{array}$ \\
\hline $\mathrm{CCU}_{1}$ & & $\begin{array}{l}\text { Lower } \\
\text { subunit }\end{array}$ & $\begin{array}{l}\text { Calcic paleosol sequence, consisting of interbedded } \\
\text { layers of pedogenically altered to unaltered gravel, sand, } \\
\text { silt, and/or clay, cemented together with one or more } \\
\text { layers of secondary } \mathrm{CaCO}_{3} \text {, originally referred to as } \\
\text { "caliche" (Brown 1959). Since then the name has } \\
\text { evolved from the Plio-Pleistocene unit (Bjornstad 1984, } \\
\text { DOE 1988, DOE-GJO 1997, Slate 2000), the Plio- } \\
\text { Pleistocene calcrete facies (DOE 1988, Wood et al. } \\
\text { 2001), the lower Plio-Pleistocene unit (Lindsey et al. } \\
\text { (2001), and the coarse- to fine-grained, CaCO } \text {-cemented }_{3} \text {-cem } \\
\text { lithofacies [CCUc-f(calc)] of the Cold Creek unit (DOE } \\
\text { 2002). Same as PPc of Lindsey et al. (2001). }\end{array}$ & $\begin{array}{l}\text { Calcic paleosols } \\
\text { developed on eroded } \\
\text { Ringold or post- } \\
\text { Ringold Fm. eolian } \\
\text { and/or fluvial } \\
\text { deposits }\end{array}$ \\
\hline
\end{tabular}


Table 2.1. (contd)

\begin{tabular}{|c|c|c|c|c|}
\hline $\begin{array}{c}\text { Stratigraphic } \\
\text { Symbol }\end{array}$ & Formation & $\begin{array}{l}\text { Facies / } \\
\text { Subunit }\end{array}$ & Description & Genesis \\
\hline Rtf & \multirow{2}{*}{$\begin{array}{l}\text { Ringold } \\
\text { Formation }\end{array}$} & $\begin{array}{l}\text { Member of } \\
\text { Taylor Flat }\end{array}$ & $\begin{array}{l}\text { Fine-grained Ringold Formation sequence consisting } \\
\text { of interstratified, well bedded fine to coarse sand to silt. } \\
\text { Equivalent to the upper Ringold unit (DOE 1988). }\end{array}$ & $\begin{array}{l}\text { Ancestral Columbia } \\
\text { River System fluvial } \\
\text { channel, crevasse } \\
\text { splay, and/or } \\
\text { overbank deposits }\end{array}$ \\
\hline Rwi & & $\begin{array}{l}\text { Member of } \\
\text { Wooded } \\
\text { Island }\end{array}$ & $\begin{array}{l}\text { Coarse-grained Ringold Formation sequence, } \\
\text { consisting of mostly moderately sorted, quartzitic sandy } \\
\text { gravel to silty sandy gravel. Equivalent to middle } \\
\text { Ringold unit (DOE 1988) and the Ringold Unit E } \\
\text { gravels (Wood et al. 2001; Lindsey et al. 2001) . }\end{array}$ & $\begin{array}{l}\text { Ancestral Columbia } \\
\text { River System fluvial, } \\
\text { braided-stream } \\
\text { deposits }\end{array}$ \\
\hline
\end{tabular}

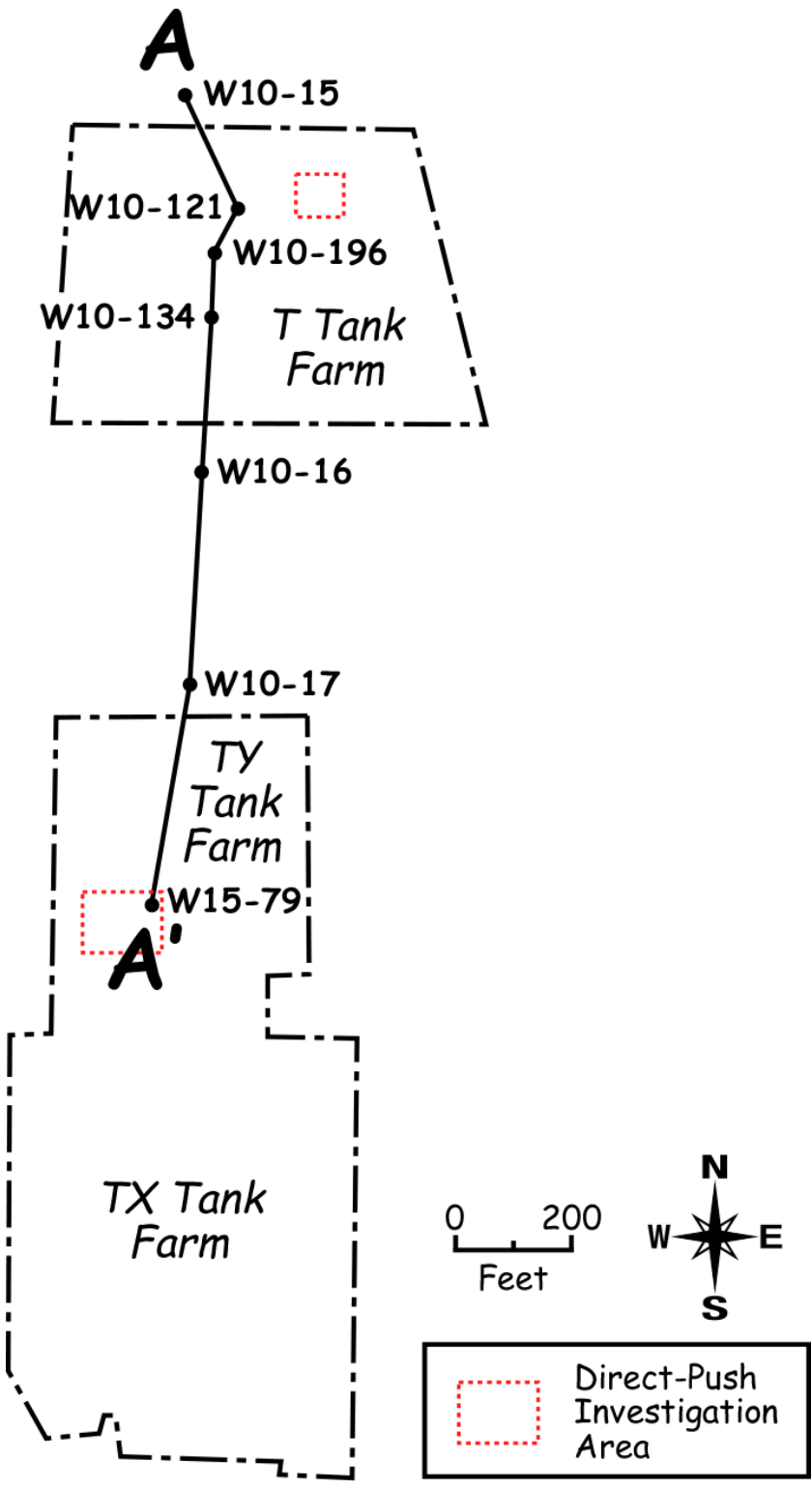

Figure 2.2. Borehole and Cross Section Location Map. Cross section A-A' is shown in Figure 2.3. 


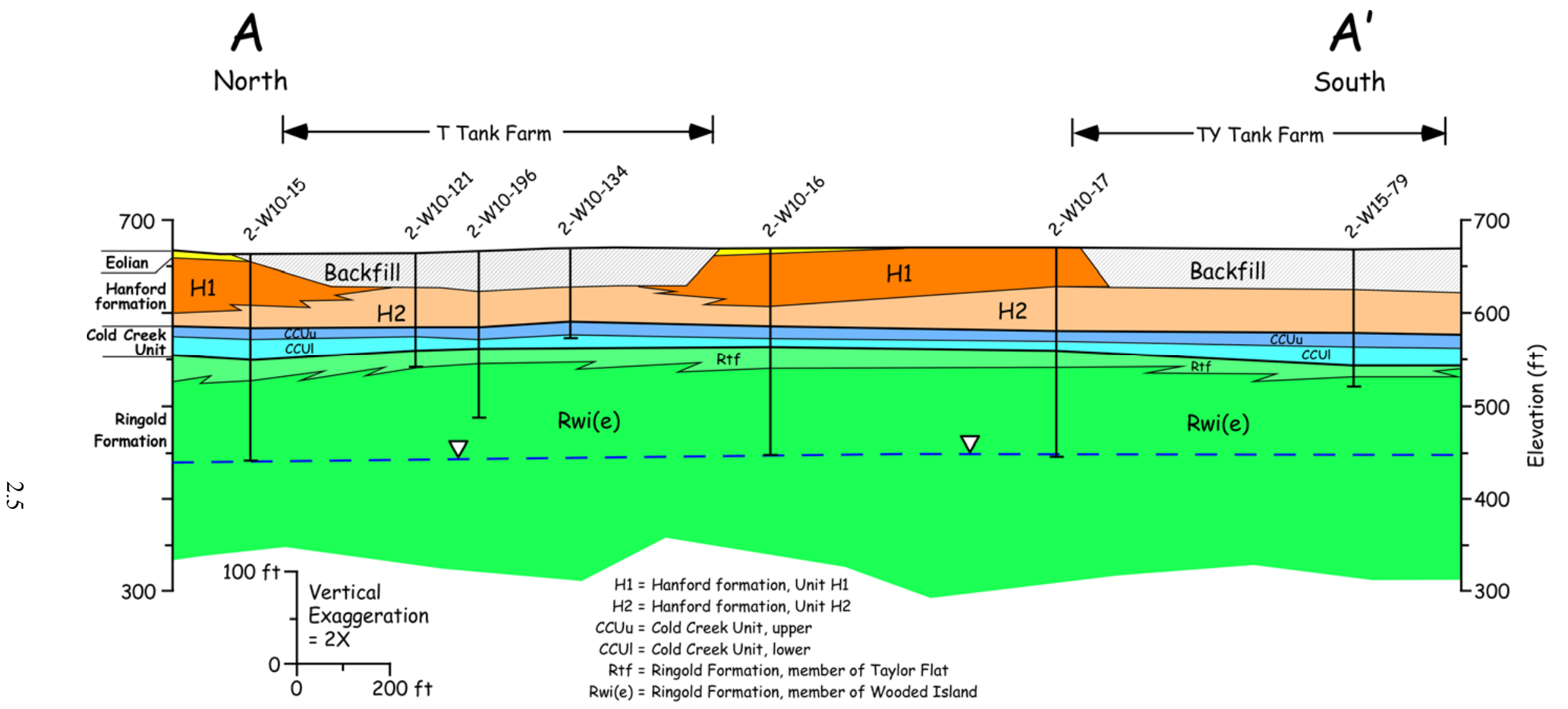

Figure 2.3. Hydrogeologic Cross Section Through the T and TY Tank Farms. See Figure 2.2 for location of cross section. 


\subsection{Characterization and Sampling Methods}

This document reports on the geologic/geochemical characterization of 11 recent vadose-zone, cone-penetrometer probe (direct push) holes drilled in the vicinity of the T and TY Tank Farms. Six of the holes were drilled in the T Tank Farm (Figure 2.4); the other five were drilled in the TY Tank Farm (Figure 2.5). Direct-push holes were drilled in two stages. First, 24 direct-push holes were advanced up to $85 \mathrm{ft}$ below ground surface for geophysical logging to target intervals for collection of core samples to be used for geological/geochemical characterization. Downhole geophysical logs measured gamma activity using up to three different detectors: 1) NaI (scintillation), 2) Geiger-Mueller (gross gamma), and 3) spectral gamma (Randall and Price 2006). Out of the 24 holes geophysically logged at the TY Tank Farm, only about $40 \%$ showed any significant gamma activity in the deep subsurface. Five direct push holes displayed a single gamma spike, usually at about $45 \mathrm{ft}$ depth below ground surface (bgs). Five other holes displayed multiple gamma spikes in the deep subsurface at $\geq 45 \mathrm{ft}$ depth bgs.

A second direct-push campaign was used to place holes near locations that showed elevated gamma activity in the first campaign for the purpose of collecting core samples. Core samples were collected from these secondary holes for geologic/geochemical characterization. In most holes, including all probe holes in the TY Tank Farm, only a single depth interval ( $\leq 2 \mathrm{ft}$ ) was sampled (Table 2.2); core recovery ranged from $15 \%$ to $110 \%$. Multiple intervals were core sampled in one of the holes in the T Tank Farm (C5378). From each interval, up to three continuous core segments were collected in 1.5-inch-diameter by 6-inch-long stainless-steel liners, and grab samples were also collected from the shoe at the base of some core intervals (Table 2.3).

In the laboratory, immediately upon extruding the cores from their liners, moisture samples were collected and high-resolution color photographs were obtained for each core or grab sample (Appendices A and C). Next, standard descriptions of grain size, sorting, color, structure, consolidation, moisture content, mineralogy, and reaction with hydrochloric acid were entered onto geologic core logs (Appendices B and D). Cores were also sub-sampled for laboratory characterization of physical and chemical properties at that time. 


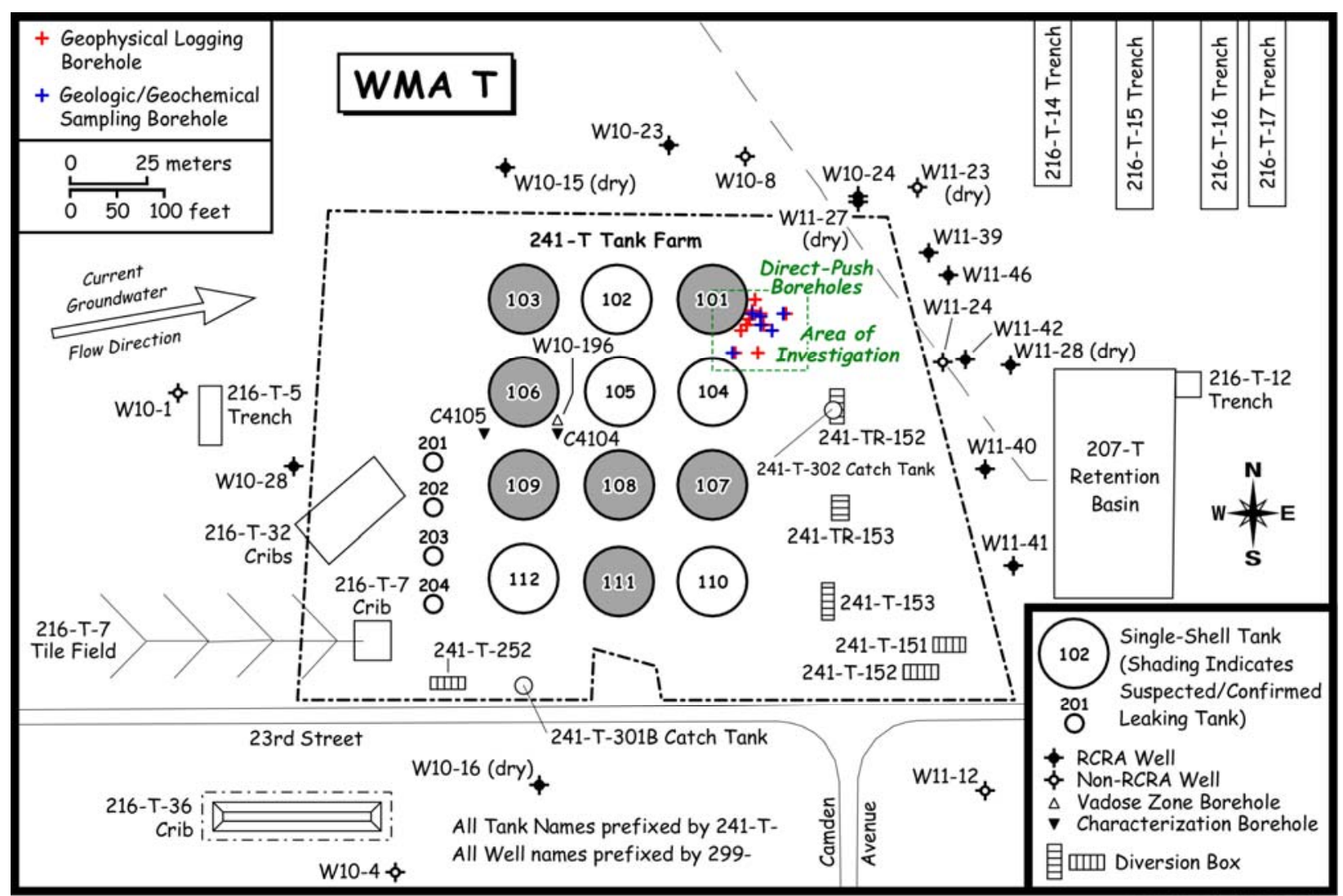

2007/DCL/T/002 (05/16)

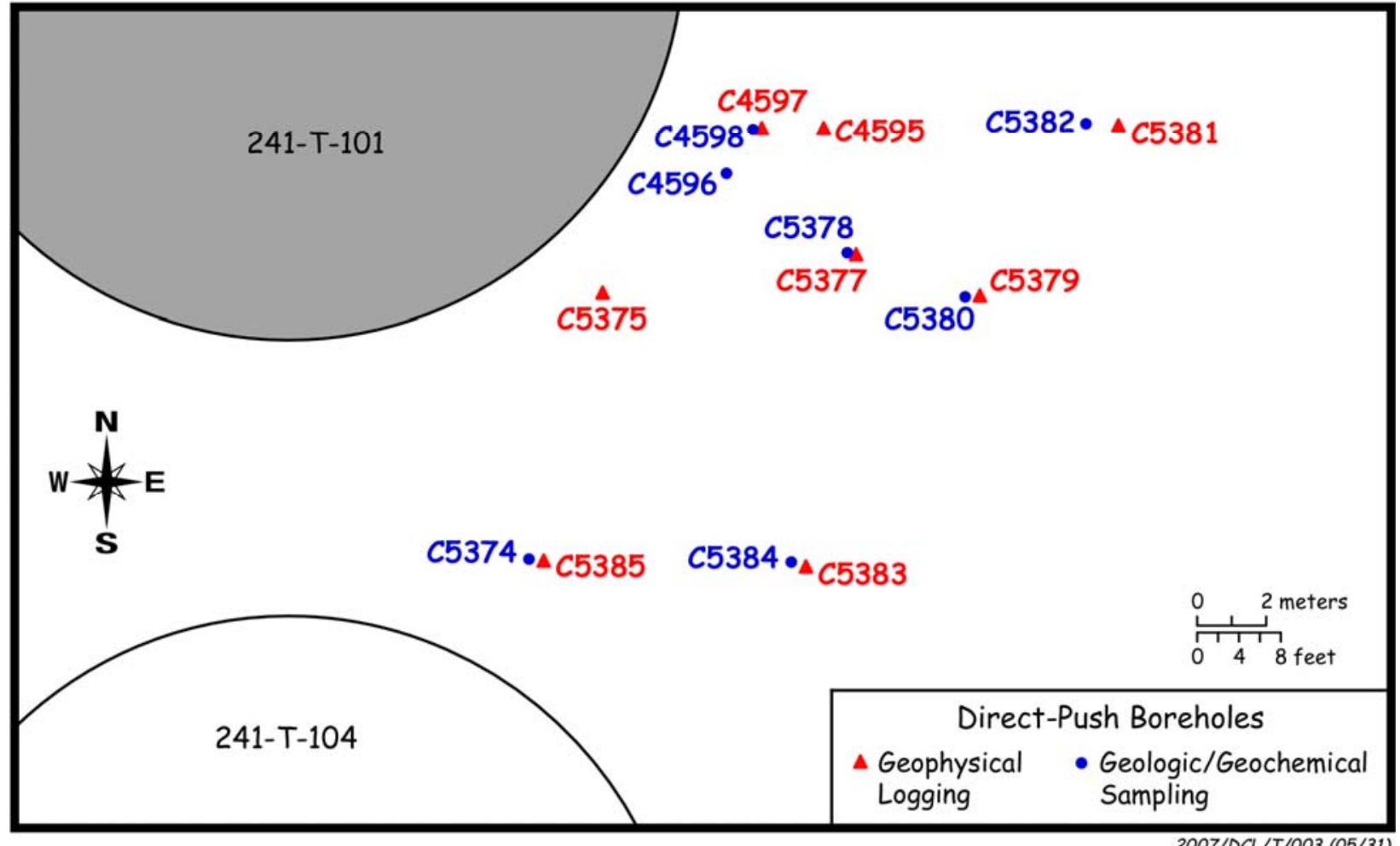

Figure 2.4. Locations of Direct Push holes in Vicinity of the T Tank Farm 


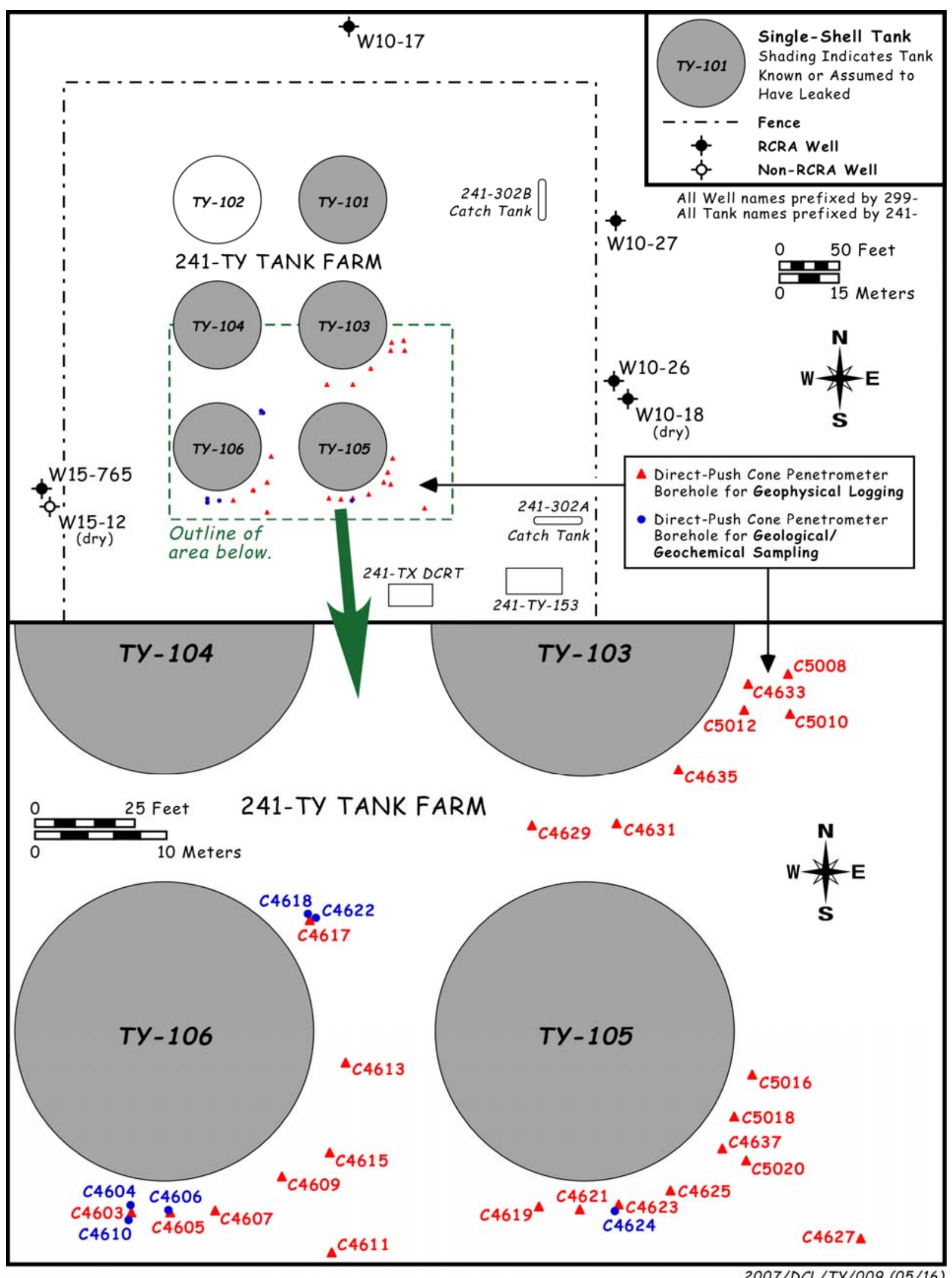

Figure 2.5. Locations of Direct-Push holes in Vicinity of the TY Tank Farm 
Table 2.2. Sampled Direct-Push Boreholes

\begin{tabular}{|c|c|c|c|c|c|c|c|c|}
\hline $\begin{array}{l}\text { Sampled Direct } \\
\text { Push Borehole }\end{array}$ & Easting & Northing & \begin{tabular}{|c|} 
Elevation at \\
Ground Surface \\
(m above mean \\
sea level)
\end{tabular} & Date Received & Date Opened & Lab Number & $\begin{array}{c}\text { Sampled } \\
\text { Depths ft bgs }\end{array}$ & $\begin{array}{c}\text { Total Length } \\
\text { Intact Core } \\
(\mathrm{ft})\end{array}$ \\
\hline \multicolumn{9}{|l|}{ 241-T Tank Farm } \\
\hline C4596 & 566853.5 & 136759.1 & 206.834 & $8 / 25 / 2006$ & $12 / 5 / 06$ & B1KC36 & $47.0-49.2$ & 2.2 \\
\hline C4598 & 566851.4 & 136759.7 & 206.552 & $8 / 18 / 2006$ & $12 / 5 / 06$ & B1KC35 & $43-44$ & 0.6 \\
\hline C5374 & 566844.9 & 136747.2 & 206.369 & $11 / 3 / 2006$ & $12 / 5 / 06$ & B1KC40 & $80-82$ & 2.0 \\
\hline C5378 & 566854.2 & 136756.1 & 206.885 & $10 / 25 / 06$ & $12 / 5 / 06$ & B1KC37 & $45-46.2$ & 1.0 \\
\hline C5378 & 566854.2 & 136756.1 & 206.885 & $10 / 27 / 06$ & $12 / 5 / 06$ & B1KC38 & $62-64$ & 2.0 \\
\hline C5384 & 566852.5 & 136747.1 & 206.704 & $10 / 27 / 06$ & $12 / 5 / 06$ & B1KC39 & $44.2-46$ & 1.8 \\
\hline C5380 & 566857.6 & 136754.8 & 207.139 & $11 / 16 / 06$ & $12 / 5 / 06$ & B1LB08 & $50-52$ & 2.0 \\
\hline C5382 & 566.861 .1 & 136759.9 & 207.341 & $11 / 16 / 06$ & $12 / 5 / 06$ & B1LB07 & $78-79.5$ & 1.5 \\
\hline \multicolumn{9}{|c|}{ 241-TY Tank Farm } \\
\hline C4604 & 566739.5 & 136370.8 & 205.631 & $11 / 3 / 05$ & $12 / 20 / 05$ & S06001-1 & $44.5-45.4$ & 0.3 \\
\hline C4606 & 566742.3 & 136370.4 & 205.653 & $11 / 3 / 05$ & $12 / 20 / 05$ & S06001-4 & $44.4-46.0$ & 1.6 \\
\hline $\mathrm{C} 4610$ & 566739.3 & 136369.7 & 205.590 & $11 / 3 / 05$ & $12 / 20 / 05$ & S06001-3 & $43.7-44.5$ & 0.8 \\
\hline C4618 & 566753.0 & 136393.0 & \multicolumn{6}{|c|}{ No sediment retrieved from borehole } \\
\hline C4622 & 566776.3 & 136392.7 & 205.653 & $11 / 11 / 05$ & $12 / 20 / 05$ & S06001-5 & $43.4-43.7$ & 0.3 \\
\hline C4624 & 566766.3 & 136370.4 & 205.780 & $11 / 3 / 05$ & $12 / 20 / 05$ & S06001-2 & $42.0-43.1$ & 1.1 \\
\hline
\end{tabular}


Table 2.3. Analyzed Samples from the T and TY Tank Farms

\begin{tabular}{|c|c|c|c|c|c|c|c|c|c|}
\hline $\begin{array}{c}\text { Sampled } \\
\text { Direct-Push } \\
\text { Borehole }\end{array}$ & Lab \# & $\begin{array}{l}\text { Sample } \\
\text { Type }\end{array}$ & $\begin{array}{l}\text { Depth } \\
\mathrm{ft} g \mathrm{gs}\end{array}$ & $\begin{array}{l}\text { Mid Depth } \\
\text { ft bgs }\end{array}$ & Lithology & $\begin{array}{l}\text { Stratigraphic } \\
\text { Unit }\end{array}$ & $\begin{array}{c}\text { Lab } \\
\text { Moisture }\end{array}$ & $\begin{array}{c}\text { Core } \\
\text { Moisture }\end{array}$ & Comments \\
\hline \multicolumn{10}{|c|}{ TY Tank Farm } \\
\hline C4604 & S06001-1A & core & $44.5-45.4$ & 44.95 & Silty sandy gravel & Hanford fm. & $5.09 \%$ & dry & pulverized \\
\hline C4604 & S06001-1 & grab & shoe & $\sim 45.3$ & Silty sandy gravel & Hanford fm. & $5.45 \%$ & moist & \\
\hline C4624 & S06001-2B & core & $42.0-42.2$ & 42.10 & $\begin{array}{c}\text { Silty sandy gravel, } \\
\text { calcareous }\end{array}$ & Hanford fm. & $5.64 \%$ & sl. moist & \\
\hline C4624 & S06001-2A & core & $42.2-42.8$ & 42.50 & $\begin{array}{c}\text { Silty sandy gravel, } \\
\text { calcareous }\end{array}$ & Hanford fm. & $8.29 \%$ & sl. moist & \\
\hline C4624 & S06001-2 & grab & $42.8-43.3$ & 43.05 & $\begin{array}{c}\text { Silty sandy gravel, } \\
\text { calcareous }\end{array}$ & Hanford fm. & $5.24 \%$ & sl. moist & \\
\hline C4610 & S06001-3A & core & $43.67-43.92$ & 43.80 & Silty sandy gravel & Hanford fm. & $5.50 \%$ & sl. moist & \\
\hline C4610 & S06001-3 & grab & $43.92-44.5$ & 44.21 & Gravelly sand & Hanford fm. & $6.18 \%$ & moist & \\
\hline C4606 & S06001-4C & core & $44.33-44.42$ & 44.38 & Silty sandy gravel & Hanford fm. & $4.26 \%$ & sl. moist & \\
\hline C4606 & S06001-4B & core & $44.42-44.92$ & 44.67 & Silty sandy gravel & Hanford fm. & $5.89 \%$ & moist & \\
\hline C4606 & S06001-4A & core & $44.92-45.42$ & 45.17 & Silty gravelly sand & Hanford fm. & $6.44 \%$ & moist & \\
\hline C4606 & $\begin{array}{c}\text { S06001-4A } \\
\text { DUP }\end{array}$ & core & $44.92-45.42$ & 45.17 & Silty gravelly sand & Hanford fm. & $6.57 \%$ & moist & \\
\hline C4606 & S06001-4 & grab & $45.42-46.0$ & 45.71 & Slightly gravelly sand & Hanford fm. & $9.73 \%$ & moist & \\
\hline C4622 & S06001-5 & grab & $43.5-43.8$ & 43.65 & $\begin{array}{c}\text { Silty sandy gravel, } \\
\text { calcareous }\end{array}$ & Hanford fm. & $4.53 \%$ & sl. moist & \\
\hline \multicolumn{10}{|l|}{ T Tank Farm } \\
\hline C4598 & B1KC35A & core & $43.5-44.0$ & 43.8 & $\begin{array}{c}\text { Slightly pebbly sand, } 1 \mathrm{t} \\
\text { gray }\end{array}$ & Hanford fm. & $3.97 \%$ & dry & \\
\hline C4598 & $\mathrm{B} 1 \mathrm{KC} 35 \mathrm{~B}$ & core & $43.0-43.5$ & 43.3 & $\begin{array}{l}\text { Slightly pebbly muddy } \\
\text { sand }\end{array}$ & Hanford fm. & $4.30 \%$ & dry & slough? \\
\hline C4596 & B1KC36 & grab & $48.5-49.2$ & 48.9 & Med-crs sand & Hanford fm. & $3.50 \%$ & sl. moist & High rad interval \\
\hline C4596 & $\mathrm{B} 1 \mathrm{KC} 36 \mathrm{~A}$ & core & $48.0-48.5$ & 48.3 & Fn-crs sand & Hanford fm. & $6.37 \%$ & sl. moist & \\
\hline $\mathrm{C} 4596$ & $\mathrm{~B} 1 \mathrm{KC} 36 \mathrm{~B}$ & core & $47.5-48.0$ & 47.8 & Med-crs sand & Hanford fm. & $4.21 \%$ & sl. moist & \\
\hline C4596 & $\mathrm{B} 1 \mathrm{KC} 36 \mathrm{C}$ & core & $47.0-47.5$ & 47.3 & Med-crs sand & Hanford fm. & $4.57 \%$ & sl. moist & \\
\hline C5378 & B1KC37A & core & $46.0-46.5$ & 46.3 & Crs sand & Hanford fm. & $2.58 \%$ & sl. moist & $\begin{array}{c}\text { Upper interval } \\
\text { from C5378 }\end{array}$ \\
\hline C5378 & $\mathrm{B} 1 \mathrm{KC} 37 \mathrm{~B}$ & core & $45.5-46.0$ & 45.8 & Med sand & Hanford fm. & $5.87 \%$ & sl. moist & \\
\hline C5378 & $\mathrm{B} 1 \mathrm{KC} 37 \mathrm{C}$ & core & $45.0-45.5$ & 45.3 & Med sand & Hanford fm. & $11.7 \%$ & sl. moist & \\
\hline
\end{tabular}


Table 2.3. (contd)

\begin{tabular}{|c|c|c|c|c|c|c|c|c|c|}
\hline \begin{tabular}{|c|} 
Sampled \\
Direct-Push \\
Borehole \\
\end{tabular} & $\mathrm{Lab} \#$ & $\begin{array}{l}\text { Sample } \\
\text { Type }\end{array}$ & $\begin{array}{l}\text { Depth } \\
\mathrm{ft} \text { gs }\end{array}$ & $\begin{array}{l}\text { Mid Depth } \\
\mathrm{ft} \text { bgs }\end{array}$ & Lithology & $\begin{array}{c}\text { Stratigraphic } \\
\text { Unit }\end{array}$ & $\begin{array}{c}\text { Lab } \\
\text { Moisture }\end{array}$ & $\begin{array}{c}\text { Core } \\
\text { Moisture }\end{array}$ & Comments \\
\hline C5378 & B1KC38 & grab & $63.5-64.0$ & 63.8 & Crs sand, basaltic & Hanford fm. & $\begin{array}{l}.40 \% \\
\end{array}$ & "sl. moist & $\begin{array}{c}\text { Lower interval } \\
\text { from C5378 }\end{array}$ \\
\hline C5378 & B1KC38A & core & $63.0-63.5$ & 63.3 & Gravelly sand, basaltic & Hanford fm. & $5.18 \%$ & sl. moist & \\
\hline C5378 & $\mathrm{B} 1 \mathrm{KC} 38 \mathrm{~B}$ & core & $62.5-63.0$ & 62.8 & Gravelly sand, basaltic & Hanford fm. & $5.48 \%$ & sl. moist & \\
\hline $\mathrm{C} 5378$ & B1KC38C & core & $62.0-62.5$ & 62.3 & Gravelly sand, basaltic & Hanford fm. & $6.51 \%$ & sl. moist & \\
\hline C5384 & B1KC39 & grab & $45.5-46.0$ & 45.8 & Med-crs sand, lt gray & Hanford fm. & $4.66 \%$ & sl. moist & $\begin{array}{l}\text { Hole \# changed } \\
\text { from C5380 }\end{array}$ \\
\hline C5384 & B1KC39A & core & $45.0-45.5$ & 45.3 & Fn-crs sand, yellowish & Hanford fm. & $3.56 \%$ & sl. moist & $\begin{array}{l}\text { Hole \# changed } \\
\text { from C5380 }\end{array}$ \\
\hline C5384 & B1KC39B & core & $44.5-45.0$ & 44.8 & Med-crs sand, lt gray & Hanford fm. & $4.54 \%$ & sl. moist & $\begin{array}{l}\text { Hole \# changed } \\
\text { from C5380 }\end{array}$ \\
\hline C5384 & B1KC39C & core & $44.0-44.5$ & 44.3 & Med-crs sand, lt gray & Hanford fm. & $6.10 \%$ & sl. moist & $\begin{array}{l}\text { Hole \# changed } \\
\text { from C5380 }\end{array}$ \\
\hline $\mathrm{C} 5380$ & B1LB08 & grab & $51.5-52.0$ & 51.8 & Gravelly sand & Hanford fm. & $5.65 \%$ & sl. moist & \\
\hline C5380 & B1LB08A & core & $51.0-51.5$ & 51.3 & Med-crs sand & Hanford fm. & $8.33 \%$ & sl. moist & \\
\hline C5380 & B1LB08B & core & $50.5-51.0$ & 50.8 & Med-crs sand & Hanford fm. & $9.14 \%$ & sl. moist & \\
\hline C5380 & B1LB08C & core & $50.0-50.5$ & 50.3 & Med-crs sand & Hanford fm. & $8.27 \%$ & sl. moist & \\
\hline $\mathrm{C} 5374$ & $\mathrm{~B} 1 \mathrm{KC} 40$ & grab & $81.5-82.0$ & 81.8 & $\begin{array}{l}\text { Fn-med sand, pale } \\
\text { yellow, laminated }\end{array}$ & $\begin{array}{l}\text { Upper Cold } \\
\text { Creek unit }\end{array}$ & $8.35 \%$ & sl. moist & \\
\hline C5374 & $\mathrm{B} 1 \mathrm{KC} 40 \mathrm{~A}$ & core & $81.0-81.5$ & 81.3 & $\begin{array}{c}\text { Fn sandy silt, yel. brn, } \\
\text { calcareous }\end{array}$ & $\begin{array}{l}\text { Upper Cold } \\
\text { Creek unit }\end{array}$ & $16.6 \%$ & moist & \\
\hline C5374 & B1KC40B & core & $80.5-81.0$ & 80.8 & $\begin{array}{l}\text { Silty fn sand, yel. brn, } \\
\text { calcareous }\end{array}$ & $\begin{array}{l}\text { Upper Cold } \\
\text { Creek unit }\end{array}$ & $18.2 \%$ & moist & \\
\hline $\mathrm{C} 5374$ & $\mathrm{~B} 1 \mathrm{KC} 40 \mathrm{C}$ & core & $80.0-80.5$ & 80.3 & $\begin{array}{l}\text { Silty fn sand, yel. brn, } \\
\text { calcareous }\end{array}$ & $\begin{array}{l}\text { Upper Cold } \\
\text { Creek unit }\end{array}$ & $14.9 \%$ & moist & \\
\hline C5382 & B1LB07A & core & $79.0-79.5$ & 79.3 & $\begin{array}{l}\text { Pale yellow silty sand, } \\
\text { laminated, calcareous }\end{array}$ & $\begin{array}{l}\text { Upper Cold } \\
\text { Creek unit }\end{array}$ & $22.7 \%$ & moist & \\
\hline C5382 & B1LB07B & core & $78.5-79.0$ & 78.8 & $\begin{array}{l}\text { Pale yellow silty sand, } \\
\text { laminated, calcareous }\end{array}$ & $\begin{array}{l}\text { Upper Cold } \\
\text { Creek unit }\end{array}$ & $14.9 \%$ & moist & \\
\hline C5382 & B1LB07C & core & $78.0-78.5$ & 78.3 & Med-crs sand & $\begin{array}{c}\text { Hanford } \\
\text { formation? }\end{array}$ & $5.98 \%$ & sl. moist & \\
\hline
\end{tabular}




\subsection{Interpreted Geology Related to Direct-Push Samples}

All the samples from the TY Tank Farm came from a depth between 43.5 and $45.5 \mathrm{ft}$ bgs within the gravel-dominated H1 unit of the Hanford formation. Samples from the T Tank Farm, on the other hand, came from a wider interval (43-82 ft bgs), which appears to include both gravel (H1)- and sanddominated (H2) units of the Hanford formation, as well as the upper Cold Creek subunit.

All the new direct push holes in the TY Tank Farm penetrated only coarse-grained cataclysmic flood deposits of the Hanford formation, while the deepest samples from the T Tank Farm reached into finegrained sediments of the upper Cold Creek unit. Except for the discrete core intervals, no direct geologic observations were made available by direct push holes. However, some indirect interpretation of lithology can be made based on the gamma logs.

Based on down-hole geophysical logs, a spike in gamma activity was often associated with the $\sim 45$-ft depth and less often at a depth of $\sim 55 \mathrm{ft}$ at the TY Tank Farm. The 45 - $\mathrm{ft}$ depth lies near the H1/H2 contact and, therefore, may reflect a capillary boundary that exists between highly contrasting lithologies along this boundary. Moisture and contaminants moving through the vadose zone have been shown to collect along highly contrasting lithologic boundaries (Serne et al. 2004a).

Unlike the C-152 direct push characterization study (Brown et al. 2007) in WMA C, which had lots of neutron geophysical log information and showed multiple moisture boundaries, there is much less information, with no moisture (neutron) logs for T and TY probe holes. Therefore, not much can be concluded about the geology penetrated by the T and TY direct push holes. 


\subsection{Geochemical Methods and Materials}

This chapter discusses the methods and philosophy used to characterize the T and TY Tank Farm probe samples and the parameters that were measured and analyzed in the laboratory. It also describes the materials and methods used to conduct analyses of the physical, geochemical, and radio-analytical properties of the sediments.

\subsection{Sample Inventory}

\subsubsection{TY Tank Farm Direct Push Samples}

Samples were numbered using a project-specific prefix, in this case S06001 for the samples collected from the TY Tank Farm, followed by a specific sample identification suffix, such as -1. At the TY Tank Farm, sediment samples were collected from five direct push probe holes (see Figure 2.5). Each direct push sampling campaign resulted in up to three depth-discrete cores $(3.8 \mathrm{~cm}$ in diameter by approximately $15.2 \mathrm{~cm}$ long) and one grab sample consisting of the material captured in the drive shoe. The core samples from each direct probe hole were further identified by the letters A, B, or C, where the A liner (the liner was the stainless steel sleeve that contained the sediment core sample) was always in the deeper position closest to the drive shoe (i.e., the protective end attached to the bottom of the drive casing). All core samples can be delineated from the grab samples by the additional A, B, or C nomenclature following the sample identification suffix, such as S06001-1A (Table 3.1). One laboratory duplicate sample was collected during core opening and is designated by the nomenclature DUP. Recovery of samples was poor, particularly for the core material: the A-sleeve from probe hole C4604 was approximately $1 / 6$ full, the $\mathrm{C}$-sleeve from probe hole $\mathrm{C} 4606$ was nearly empty, and the B-sleeve from C4624 and the A-sleeve from C4610 were approximately 1/2 full. For probe hole C4622, only sediment within the shoe was recovered.

\subsubsection{T Tank Farm Direct Push Samples}

At the T Tank Farm, sediment samples were collected from seven direct push holes (see Figure 2.4). Each direct push sampling campaign resulted in up to three depth-discrete cores (1.25 inches in diameter by 6 inches long) and one grab sample consisting of the material captured in the drive shoe. Each sample interval collected within the T Tank Farm was numbered using Hanford Environmental Information System (HEIS)- specific sample names. The core samples from each sample interval were further identified by the letters A, B, or C, where the A Liner was always in the deeper position closest to the drive shoe. Three laboratory duplicate samples were collected during core opening and are designated by the nomenclature DUP. Recovery of samples was fairly good in most of the probe holes. The one exception was probe hole $\mathrm{C} 4598$, which had no material recovered from the shoe, one full liner, and one partially full liner. Details about the T Tank Farm direct push samples are in Table 3.2.

\subsection{Approach}

During a past investigation at WMA SX, it was found that changes in sediment type and contaminant concentrations often occurred within a distance of a few inches within a given liner (Serne et al. 2002b). It was concluded that a more methodical scoping approach would be necessary to provide the technical 
Table 3.1. Sample Inventory from the TY Tank Farm Direct Push Probe Holes

\begin{tabular}{||l|c|c|c|c|c||}
\hline \multicolumn{1}{|c|}{$\begin{array}{c}\text { Sample } \\
\text { Number }\end{array}$} & $\begin{array}{c}\text { Probe Hole } \\
\text { Number }\end{array}$ & $\begin{array}{c}\text { Sample } \\
\text { Recovery (\%) }\end{array}$ & $\begin{array}{c}\text { Sample } \\
\text { Number }\end{array}$ & $\begin{array}{c}\text { Probe Hole } \\
\text { Number }\end{array}$ & $\begin{array}{c}\text { Sample } \\
\text { Recovery (\%) }\end{array}$ \\
\hline \hline S06001-1A & C4604 & 20 & S06001-3 & C4610 & NA \\
\hline S06001-1 & C4604 & NA & S06001-4C & C4606 & 10 \\
\hline S06001-2B & C4624 & 50 & S06001-4B & C4606 & 100 \\
\hline S06001-2A & C4624 & 90 & S06001-4A & C4606 & 100 \\
\hline S06001-2 & C4624 & NA & S06001-4 & C4606 & NA \\
\hline S06001-3A & C4610 & 50 & S06001-5 & C4622 & 65 \\
\hline $\begin{array}{l}\text { Shaded cells indicate grab samples. } \\
\text { NA indicates not applicable. }\end{array}$ \\
\hline
\end{tabular}

Table 3.2. Sample Inventory from the T Tank Farm Direct Push Probe Holes

\begin{tabular}{||l|c|c|c|c|c||}
\hline $\begin{array}{c}\text { Sample } \\
\text { Number }\end{array}$ & $\begin{array}{c}\text { Probe Hole } \\
\text { Number }\end{array}$ & $\begin{array}{c}\text { Sample } \\
\text { Recovery (\%) }\end{array}$ & $\begin{array}{c}\text { Sample } \\
\text { Number }\end{array}$ & $\begin{array}{c}\text { Probe Hole } \\
\text { Number }\end{array}$ & $\begin{array}{c}\text { Sample } \\
\text { Recovery (\%) }\end{array}$ \\
\hline \hline B1KC35B & C4598 & 20 & B1KC39B & C5384 & 95 \\
\hline B1KC35A & C4598 & 90 & B1KC39A & C5384 & 95 \\
\hline B1KC36C & C4596 & 100 & B1KC39 & C5384 & NA \\
\hline B1KC36B & C4596 & 95 & B1KC40C & C5374 & 100 \\
\hline B1KC36A & C4596 & 100 & B1KC40B & C5374 & 100 \\
\hline B1KC36 & C4596 & NA & B1KC40A & C5374 & 100 \\
\hline B1KC37C & C5378 & 70 & B1KC40 & C5374 & NA \\
\hline B1KC37B & C5378 & 95 & B1LB07C & C5382 & 100 \\
\hline B1KC37A & C5378 & 40 & B1LB07B & C5382 & 100 \\
\hline B1KC38C & C5378 & 95 & B1LB07A & C5382 & 85 \\
\hline B1KC38B & C5378 & 95 & B1LB08C & C5380 & 100 \\
\hline B1KC38A & C5378 & 75 & B1LB08B & C5380 & 100 \\
\hline B1KC38 & C5378 & NA & B1LB08A & C5380 & 100 \\
\hline B1KC39C & C5384 & 100 & B1LB08 & C5380 & NA \\
\hline $\begin{array}{l}\text { Shaded cells indicate grab samples. } \\
\text { NA indicates not applicable. }\end{array}$
\end{tabular}

justification for selecting samples for detailed characterization as defined in the data quality objectives process (DOE 1999). Subsequently, a method was developed to select samples that considered depth, geology (e.g., lithology, grain-size composition, and carbonate content, etc.), individual liner contaminant concentration (e.g., radionuclides, nitrate), moisture content, and overall sample quality. Extraction/ leaching procedures were performed and certain key parameters (i.e., moisture content, gamma energy analysis) were measured on sediment from each liner. Grab samples were only utilized as part of this study if sufficient sample material for characterization and analysis was not contained in the core samples.

During the geologic examination of the core samples, the liner contents were sub-sampled for moisture content, gamma-emission radiocounting, 1:1 water extracts (which provide soil $\mathrm{pH}$, electrical conductivity (EC), cation, and anion data), total carbon and inorganic carbon content, and $8 \mathrm{M}$ nitric acid extracts (which provide a measure of the total-leachable sediment content of contaminants). Sampling preference was always biased towards the finer-grained and/or wetter material contained in each liner. The remaining sediment from each liner was then sealed and placed in cold storage. 


\subsection{Materials and Methods}

During sub-sampling of each core liner, every effort was made to minimize moisture loss and prevent cross contamination between samples. Depending on the sample matrix, very coarse pebbles and larger material (i.e., $>32 \mathrm{~mm}$ ) were avoided during sub-sampling. Larger substrate was excluded to provide moisture contents representative of gamma energy analysis and 1:1 sediment:water extract samples. Therefore, the results from the sub-sample measurements may contain a possible bias toward higher concentrations for some analytes that would be preferentially associated with the smaller sized sediment fractions.

Procedures ASTM D2488-93 (1993) and PNL-MA-567-DO-1 (PNL 1990) were followed for visual descriptions and geological descriptions of all direct push samples. The sediment classification scheme used for geologic identification of the sediment types (used solely for graphing purposes in this report) was based on the modified Folk/Wentworth classification scheme (1968/1922).

\subsubsection{Moisture Content}

Gravimetric water contents of the sediment samples from each liner and shoe grab sample were determined using PNNL procedure PNNL-AGG-WC-001 (PNNL 2005). This procedure is based on the American Society for Testing and Materials procedure "Test Method for Laboratory Determination of Water (Moisture) Content of Soil and Rock by Mass" (ASTM D2216-98 [ASTM 1998]). One representative sub-sample of at least 15 to $70 \mathrm{~g}$ was used. Sediment aliquots were placed in tared containers, weighed, and dried in an oven at $105^{\circ} \mathrm{C}$ until constant weight was achieved, which took at least 24 hours. The containers were removed from the oven, sealed, cooled, and weighed. At least two weighings, each after a 24-hour heating period, were performed to ensure that all moisture was removed. All weighings were performed using a calibrated balance. A calibrated weight set was used to verify balance performance before weighing the samples. The gravimetric water content was computed as the percentage change in soil weight before and after oven drying.

\subsubsection{1:1 Sediment:Water Extracts}

Water-soluble inorganic constituents were determined using a 1:1 sediment:deionized-water extract method. This method was chosen because the sediment was too dry to easily extract vadose zone pore water. The extracts were prepared by adding an exact weight of deionized water to approximately 60 to $80 \mathrm{~g}$ of sediment sub-sampled from each liner or drive shoe grab sample. The weight of deionized water needed was calculated based on the weight of the field-moist samples and their previously determined moisture contents. The sum of the existing moisture (pore water) and the deionized water was fixed at the mass of the dry sediment. An appropriate amount of deionized water was added to screw cap jars containing the sediment samples. The jars were sealed and briefly shaken by hand, then placed on a mechanical orbital shaker for one hour. The samples were allowed to settle, generally overnight, until the supernatant liquid was fairly clear. The supernatant was carefully decanted and separated into unfiltered aliquots for conductivity and $\mathrm{pH}$ determinations and into filtered aliquots (passed through $0.45 \mu \mathrm{m}$ membranes) for anion, cation, alkalinity, and radionuclide analyses. More details can be found in Rhoades (1996) and within Methods of Soils Analysis - Part 3 (ASA 1996). 


\subsubsection{1 $\quad \mathrm{pH}$ and Conductivity}

Two approximately 3-mL aliquots of the unfiltered 1:1 sediment:water extract supernatants were used for $\mathrm{pH}$ and conductivity measurements. The $\mathrm{pH}$ of the extracts was measured with a solid-state $\mathrm{pH}$ electrode and a pH meter calibrated with buffers 4, 7, and 10. Electrical conductivity was measured and compared to potassium chloride standards with a range of $0.001 \mathrm{M}$ to $1.0 \mathrm{M}$.

\subsubsection{Anions}

The 1:1 sediment:water extracts were analyzed for anions using ion chromatography (IC). Fluoride, chloride, nitrite, bromide, nitrate, carbonate, phosphate, and sulfate were separated on a Dionex AS17 column with a gradient elution of $1 \mathrm{mM}$ to $35 \mathrm{mM}$ sodium hydroxide and measured using a conductivity detector. This methodology is based on U.S. Environmental Protection Agency (EPA) Method 300.0A (EPA 1984) with the exception of using the gradient elution of sodium hydroxide. Water extract chromatograms were visually scanned to ensure there were no unidentified peaks caused by other constituents.

\subsubsection{Cations and Trace Metals}

Major cation analysis was performed using an inductively coupled plasma-optical emission spectroscopy (ICP-OES) unit using high-purity calibration standards to generate calibration curves and verify continuing calibration during the analysis run. Multiple dilutions were made of each 1:1 water extract for analysis to investigate and correct for matrix interferences. Details of this method are found in EPA Method 6010B (EPA 2000b). The second instrument used to analyze trace metals, including technetium-99 and uranium-238, was an inductively coupled plasma-mass spectrometer (ICP-MS) using PNNL-AGG-415 method (PNNL 1998). This method is quite similar to EPA Method 6020 (EPA 2000c).

\subsubsection{Alkalinity}

The alkalinity of several of the 1:1 sediment:water extracts was measured using standard titration. The alkalinity procedure is equivalent to the U.S. Geological Survey (USGS) National Field Manual (USGS 2001) method.

\subsubsection{5 $\quad 8$ M Nitric Acid Extract}

Approximately $20 \mathrm{~g}$ of oven-dried sediment was contacted with $8 \mathrm{M}$ nitric acid at a ratio of approximately five parts acid to one part sediment. The slurries were heated to about $80^{\circ} \mathrm{C}$ for several hours, then the fluid was separated by filtration through $0.45 \mu \mathrm{m}$ membranes. The acid extracts were analyzed for major cations and trace metals using ICP-OES and ICP-MS techniques, respectively. The acid digestion procedure is based on EPA SW-846 Method 3050B (EPA 2000a).

\subsubsection{Gamma Energy Analysis}

Gamma energy analysis (GEA) was performed on sediment from the direct push liners. All samples for GEA were analyzed using 60\% efficient intrinsic germanium gamma detectors. All germanium counters were efficiency calibrated for distinct geometries using mixed gamma standards traceable to the National Institute of Standards and Technology (NIST). Field-moist samples were placed in $150-\mathrm{cm}^{3}$ counting containers and analyzed for 100 minutes in a fixed geometry. All spectra were background- 
subtracted. Spectral analysis was conducted using libraries containing most mixed fission products, activation products, and natural decay products. Control samples were run throughout the analysis to ensure correct operation of the detectors. The controls contained isotopes with photo peaks spanning the full detector range and were monitored for peak position, counting rate, and full-width half-maximum. Details are found in Gamma Energy Analysis, Operation, and Instrument Verification using Genie2000 Support Software (PNNL 1997).

\subsubsection{Carbon Content of Sediment}

The total carbon concentration in aliquots of sediment from the core liners was measured with a Shimadzu TOC-V CSN instrument with a SSM-5000A Total Organic Carbon Analyzer by combustion at approximately $900^{\circ} \mathrm{C}$ based on ASTM Method, Standard Test Methods for Analysis of Metal Bearing Ores and Related Materials by Combustion Infrared Absorption Spectrometry (ASTM E1915-01, 2001). Samples were placed into pre-combusted, tared, ceramic combustion sample holders and weighed on a calibrated balance. After the combustion sample holders were placed into the furnace introduction tube, an approximately 2-minute waiting period was allowed for the ultra-pure oxygen carrier gas to remove any carbon dioxide introduced to the system from the atmosphere during sample placement. After this sparging process, the sample was moved into the combustion furnace and the combustion was begun. The carrier gas then delivered the sample combustion products to the cell of a non-dispersive infrared (NDIR) gas analyzer where the carbon dioxide was detected and measured. The amount of $\mathrm{CO}_{2}$ measured is proportional to the total carbon content of the sample. Adequate system performance was confirmed by analyzing known quantities of a calcium carbonate standard.

Sediment samples were analyzed for inorganic carbon content by placing a sediment aliquot into a ceramic combustion boat. The combustion boat was placed into the sample introduction tube where it was sparged with ultra-pure oxygen for two minutes to remove atmospheric carbon dioxide. A small amount (usually $0.6 \mathrm{ml}$ ) of $3 \mathrm{M}$ phosphoric acid was then added to the sample in the combustion boat. The boat was moved into the combustion furnace where it was heated to $200^{\circ} \mathrm{C}$. Samples were completely covered by the acid to allow full reaction to occur. Ultra-pure oxygen swept the resulting carbon dioxide through a dehumidifier and scrubber into the cell of a NDIR gas analyzer where the carbon dioxide was detected and measured. The amount of $\mathrm{CO}_{2}$ measured is proportional to the inorganic carbon content of the sample.

Organic carbon content was determined by the difference between the inorganic carbon and total carbon concentrations.

\subsubsection{Technetium-99 Extraction and Analysis}

A subset of samples from the direct push probe holes emplaced with the T Tank Farm were selected for a comprehensive investigation of water vs. acid soluble technetium-99. The four deepest samples collected from probe hole $\mathrm{C} 5374$ (B1KC40, B1KC40A, B1KC40B, and $\mathrm{B} 1 \mathrm{KC} 40 \mathrm{C})$ as well as one uncontaminated sediment (C3177) were extracted in triplicate using either the 1:1 sediment:water or $8 \mathrm{M}$ nitric acid extractions described in the previous section. A third extraction technique, microwave-assisted digestion, was also performed. Using this technique, approximately $300 \mathrm{mg}$ of sediment was placed in a 100-mL Teflon microwave digestion vessel. Following this, $10 \mathrm{~mL}$ water, $5 \mathrm{~mL}$ of 16-M nitric acid $\left(\mathrm{HNO}_{3}\right), 2 \mathrm{~mL}$ of 12-M hydrochloric acid ( $\mathrm{HCl}$ ), and $1 \mathrm{~mL}$ of 29-M hydrofluoric acid (HF) were added, and the vessel was sealed and placed in a MARS5 ${ }^{\text {TM }}$ microwave-assisted digestion system (CEM 
Corporation, Matthews, NC). The samples were heated at the EPA-recommended temperatures and times. The samples were then allowed to cool, and $0.45 \mathrm{~g}$ of powdered boric acid was added to the digestate, which was then shaken by hand. Boric acid reacts with residual HF in the digestate to form a boron complex (preventing the residual HF from etching the sample introduction glassware in the ICP-MS instrument). Although there were no visible solids in the digestate, samples were filtered through a $0.45-\mu \mathrm{m}$-pore-size syringe filter prior to analysis.

Recoveries for technetium-99 during the respective extraction processes were evaluated using preparation blanks, blank spikes, and matrix spikes. Preparation blanks were composed of matrix appropriate solutions (i.e., deionized water, $8 \mathrm{M} \mathrm{HNO}_{3}$, or microwave digestion acids) known to be free of technetium-99. The blank spikes consisted of the same matrix appropriate solutions containing $0.3 \mu \mathrm{g} / \mathrm{L}$ technetium-99, while the matrix spikes consisted of actual samples spiked with $0.3 \mu \mathrm{g} / \mathrm{L}$ technetium-99. These quality control samples, as well as the $1: 1$ sediment:water extracts, $8 \mathrm{M}$ nitric acid extracts, and microwave assisted digestates were analyzed for technetium-99 using ICP-MS.

An aliquot of each filtered extract or digestate (from above) was further processed using TEVA® resin (Eichrom, Darien, IL) and reanalyzed for technetium-99 via ICP-MS. This additional step was performed to ensure that any matrix effects resulting from the extraction or digestion process could be removed prior to analysis of the samples. The samples were prepared for processing by drying $10 \mathrm{~mL}$ aliquots of the nitric acid extracts and microwave-digested samples under a heat lamp. Once dried, the samples were brought to $10 \mathrm{~mL}$ with $0.1-\mathrm{M} \mathrm{HNO}_{3}$. All three types of $10 \mathrm{~mL}$ aliquots of the $1: 1$ sediment:water extracts were acidified with concentrated $\mathrm{HNO}_{3}$ to a final concentration of $0.1 \mathrm{M}$. These $10 \mathrm{~mL}$ solutions were added to columns containing $2 \mathrm{~mL}$ of TEVA ${ }^{\circledR}$ resin that had been previously cleaned/conditioned using $5 \mathrm{~mL}$ of a $0.1-\mathrm{M} \mathrm{HNO}_{3}$ solution. Under these conditions the TEVA@resin selectively captures pertechnetate species but allows most other solutes to pass through the resins. After addition of the samples, the columns were further flushed by flowing $20 \mathrm{~mL}$ of a 1-M $\mathrm{HNO}_{3}$ solution through each column. The technetium-99 trapped in the columns was eluted using $10 \mathrm{~mL}$ of a $12-\mathrm{M}$ $\mathrm{HNO}_{3}$ solution. The eluted solution containing the technetium-99 was collected in a $20-\mathrm{mL}$ glass liquid scintillation vial and evaporated to dryness under a heat lamp. Once the solution was completely evaporated, $5 \mathrm{~mL}$ of a $2 \% \mathrm{HNO}_{3}$ solution was added to the vials, and the samples were analyzed for technetium-99 via ICP-MS.

\subsubsection{Stable Ruthenium Analysis}

A subset of samples from the direct push probe holes emplaced within the T Tank Farm was selected for stable ruthenium isotopic analysis. Aliquots of the 1:1 sediment:water extracts from the four deepest samples collected from probe hole C5374 (B1KC40, B1KC40A, B1KC40B, and B1KC40C) were further

processed using ion exchange resin. Specifically, $10 \mathrm{~mL}$ aliquots of the water extracts were acidified with $\mathrm{HCl}$ to a final concentration of $5 \%$ (by volume) and added to columns containing $1 \mathrm{~mL}$ of Dowex-1 100200 mesh anion exchange resin, which should have adsorbed anionic ruthenium species $\left[\mathrm{RuO}_{4}{ }^{2-}\right]$. The resin columns had been conditioned with $5 \% \mathrm{HCl}$ prior to addition of the acidified water extracts. After addition of the extracts, the columns were rinsed with $5 \mathrm{~mL}$ of $5 \% \mathrm{HCl}$. The columns were then flushed with $10 \mathrm{~mL}$ of deionized water. Finally, the ruthenium was eluted from the columns using $10 \mathrm{~mL}$ of $8 \mathrm{M}$ $\mathrm{HNO}_{3}$. All of the eluted ruthenium solutions that passed through the anion exchange columns, including the $5 \% \mathrm{HCl}$ rinsate, the deionized water rinsate, and the $8 \mathrm{M}$ nitric acid rinsate, were analyzed for ruthenium isotopes using ICP-MS after adjusting the nitric acid molarity to $0.3 \mathrm{M}$. 


\subsection{Results and Discussion}

This section presents the geochemical and physical characterization data collected on sediment from the direct push holes emplaced within the T and TY Tank Farms. These characterization activities emphasized tests that provided basic characterization data and were key to determining the distribution of mobile contaminants in the vadose zone sediments. Such information on the direct push sediments included moisture content, total and inorganic carbon content, and $\mathrm{pH}$, electrical conductivity (EC), and measurements of major cations, anions, and trace metals (including technetium-99 and uranium-238). Gamma energy analysis (GEA) of the sediments was also performed to search for any detectable manmade gamma-emitting radionuclides.

\subsection{Vadose Zone Sediment from the TY Tank Farm Direct Push Samples}

\subsubsection{Moisture Content}

The moisture contents of the seven core liners and five grab samples collected from the TY direct push holes are presented as a function of depth in Table 4.1 and Figure 4.1. Two samples displayed slightly elevated moisture contents: the A-sleeve of probe hole C4624 (8.29\%) and the shoe material from C4606 (9.73\%). The A and B liners from probe hole C4624 contained sediment with appreciably different moisture contents (greater than $30 \%$ difference), indicating that the contact for the zone of increased moisture was encountered within the $0.8 \mathrm{ft}$ sampling interval. Photographs of the sediment removed from each liner are included in Appendix A of this report. The average gravimetric moisture content of all of the TY direct push samples measured in this study was $6.1 \mathrm{wt} \%$, which was slightly higher than the average moisture content in core samples collected within the Hanford formation $\mathrm{H} 2$ unit (3.9\%) at the nearby TX Tank Farm characterization borehole (background borehole 299-W10-27 just east of the TY Tank Farm) (Serne et al. 2004b). However, the TY direct samples were collected at the interface between the backfill and Hanford formation; therefore, the elevated moisture measured in these samples could be an artifact of the compaction that occurred at this interface during construction of the tank farm or of the capillary boundary along this discontinuity.

Table 4.1. Gravimetric Moisture Content of Samples Obtained from the TY Tank Farm Direct Push Probe Holes

\begin{tabular}{||l|c|c|c||}
\hline \multicolumn{1}{|c|}{ Sample ID } & Probe Hole ID & Mid-Depth ft bgs & Moisture (\%) \\
\hline \hline S06001-1A & C4604 & 44.95 & $5.09 \%$ \\
\hline S06001-1 & C4604 & NR & $5.45 \%$ \\
\hline S06001-2B & C4624 & 42.10 & $5.64 \%$ \\
\hline S06001-2A & C4624 & 42.50 & $8.29 \%$ \\
\hline S06001-2 & C4624 & 43.05 & $5.24 \%$ \\
\hline S06001-3A & C4610 & 43.80 & $5.50 \%$ \\
\hline S06001-3 & C4610 & 44.21 & $6.18 \%$ \\
\hline S06001-4C & C4606 & 44.38 & $4.26 \%$ \\
\hline S06001-4B & C4606 & 44.67 & $5.89 \%$ \\
\hline S06001-4A & C4606 & 45.17 & $6.44 \%$ \\
\hline S06001-4A DUP & C4606 & 45.17 & $6.57 \%$ \\
\hline S06001-4 C4606 & 45.71 & $9.73 \%$ \\
\hline S06001-5 & C4622 & 43.65 & $4.53 \%$ \\
\hline $\begin{array}{l}\text { NR indicates the information was not recorded on the chain of custody. } \\
\text { Shaded cells indicate grab samples. }\end{array}$ \\
\hline
\end{tabular}




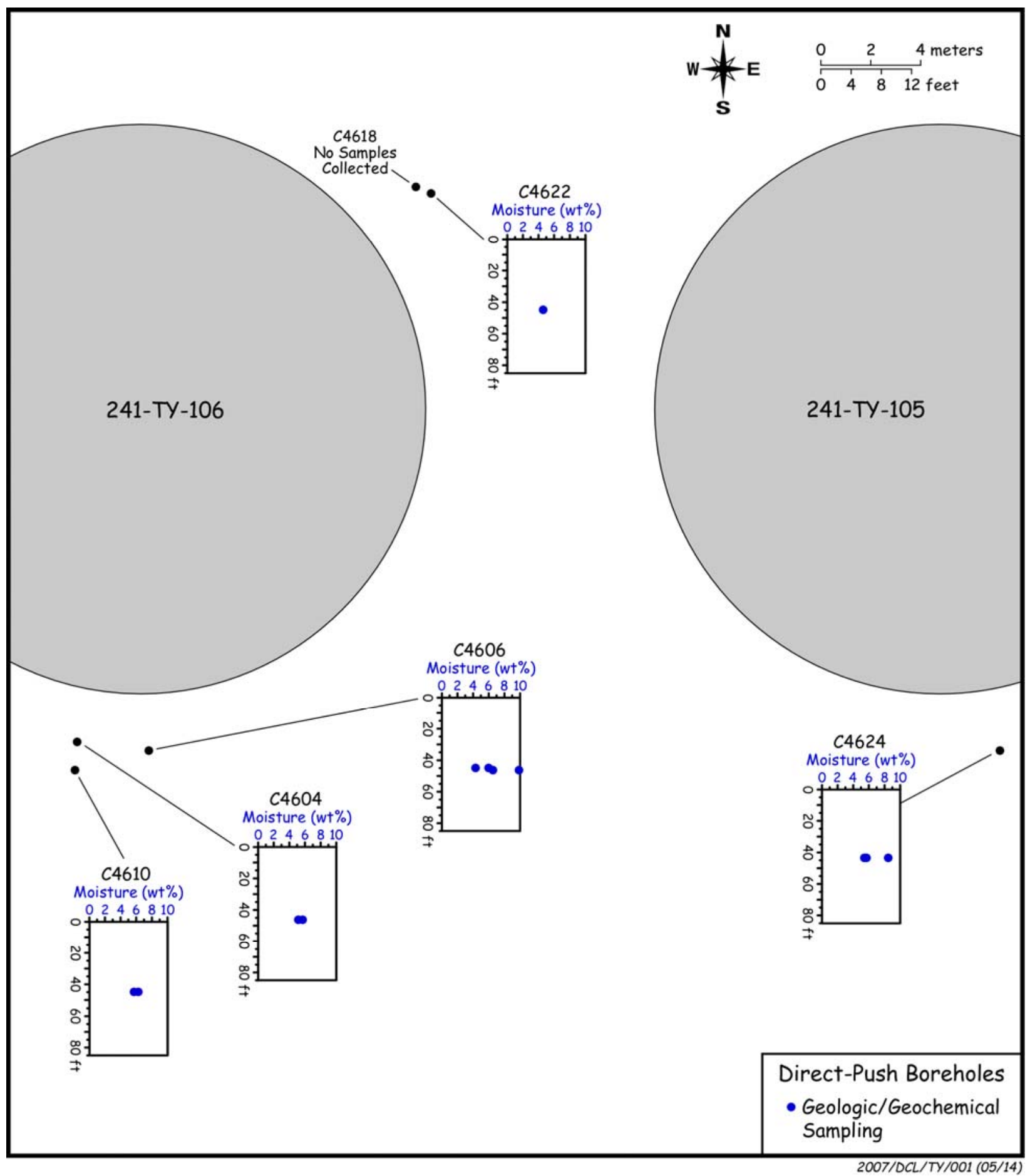

Figure 4.1. Moisture Content Data for the TY Tank Farm Direct Push Samples

\subsubsection{1:1 Sediment:Water Extracts}

The samples from the TY Tank Farm direct push were characterized by performing 1:1 sediment:water extracts. The following tables present the mass of a given constituent leached per gram of sediment as measured in the water extracts. Other tables show dilution-corrected values that represent 
concentrations in vadose zone pore water. As discussed in several other Vadose Zone Characterization Project reports, the dilution-corrected 1:1 sediment:water extracts are a reasonable estimate of the actual vadose zone pore water in contaminated sediments, but slightly over predict actual pore water concentrations in uncontaminated sediments (see Serne et al. 2002a, 2002b, 2002c, 2002e, 2002f).

\subsubsection{1 $\quad \mathrm{pH}$ and Electrical Conductivity}

The 1:1 sediment:water extract $\mathrm{pH}$ and EC data for the TY Tank Farm core and grab samples are shown in Table 4.2 and Figure 4.2. The $\mathrm{pH}$ is tabulated as measured in the 1:1 sediment:water extracts but the EC is corrected for dilution and tabulated as if it was actual pore water. Nearly all of the extract samples tested had $\mathrm{pH}$ values in the normal range for Hanford formation sediments (between 7.5 and 8.5). However, one of the core samples, S06001-1A from probe hole C4604, had a slightly elevated pH value of 8.63. In comparison, sample S06001-4C from probe hole C4610 (just south of C4604) had a pH of 7.61. Therefore, it is possible that the elevated $\mathrm{pH}$ data for sample S006001-A indicates the presence of caustic tank-related waste from tank 241-TY-106. Previous borehole reports have shown that regions of elevated soil $\mathrm{pH}$ are considered to be good indicators of the location of the original leak event or very near-field close to the initial tank waste entry zone (see Serne et al. 2002a, 2002b, 2002c, 2002e, 2002f).

The pore water-corrected EC data for all of the samples from TY Tank Farm were low, with a range of 1.71 to $4.62 \mathrm{mS} / \mathrm{cm}$. The average EC of the grab and core samples was $3.2 \mathrm{mS} / \mathrm{cm}$, which is significantly lower than the average calculated porewater EC $(20.4 \mathrm{mS} / \mathrm{cm})$ in samples from the background borehole 299-W10-27 emplaced east of the TY Tank Farm as part of the TX Tank Farm characterization effort. For comparison, two contaminated boreholes located near the TY Tank Farm, C4104 (near T-106) and C3831 (near TX-107), had average pore water-corrected EC values of 14.2 and $8.7 \mathrm{mS} / \mathrm{cm}$, with peak EC values of 33.4 and 43.3, respectively. Therefore, the porewater in the sediment samples collected around the TY Tank Farm appeared to be dilute with respect to the dissolved salts in comparison to contaminated core samples from C3831 (near TX-107) and C4104 (near T-106).

Table 4.2. $\mathrm{pH}$ for 1:1 Sediment:Water Extracts and Dilution-Corrected EC Values from TY Tank Farm Core and Grab Samples

\begin{tabular}{|c|c|c|c|c|}
\hline $\begin{array}{c}\text { Sample } \\
\text { ID }\end{array}$ & $\begin{array}{c}\text { Probe Hole } \\
\text { ID }\end{array}$ & $\begin{array}{l}\text { Mid-Depth } \\
\mathrm{ft} \text { bgs }\end{array}$ & $\mathrm{pH}$ & $\begin{array}{c}\text { Conductivity } \\
(\mathrm{mS} / \mathrm{cm})\end{array}$ \\
\hline S06001-1A & C4604 & 44.95 & 8.63 & 3.12 \\
\hline S06001-1 & C4604 & NR & 7.98 & 3.59 \\
\hline S06001-2B & C4624 & 42.10 & 8.12 & 3.68 \\
\hline S06001-2A & C4624 & 42.50 & 7.70 & 2.71 \\
\hline S06001-2 & C4624 & 43.05 & 7.64 & 3.13 \\
\hline S06001-3A & $\mathrm{C} 4610$ & 43.80 & 7.73 & 4.18 \\
\hline S06001-3 & C4610 & 44.21 & 7.65 & 2.75 \\
\hline S06001-4C & C4606 & 44.38 & 7.61 & 4.62 \\
\hline S06001-4B & $\mathrm{C} 4606$ & 44.67 & 7.59 & 2.75 \\
\hline S06001-4A & C4606 & 45.17 & 7.27 & 2.66 \\
\hline S06001-4A DUP & C4606 & 45.17 & 7.51 & 2.18 \\
\hline S06001-4 & C4606 & 45.71 & 7.63 & 1.71 \\
\hline S06001-5 & C4622 & 43.65 & 7.70 & 4.08 \\
\hline
\end{tabular}




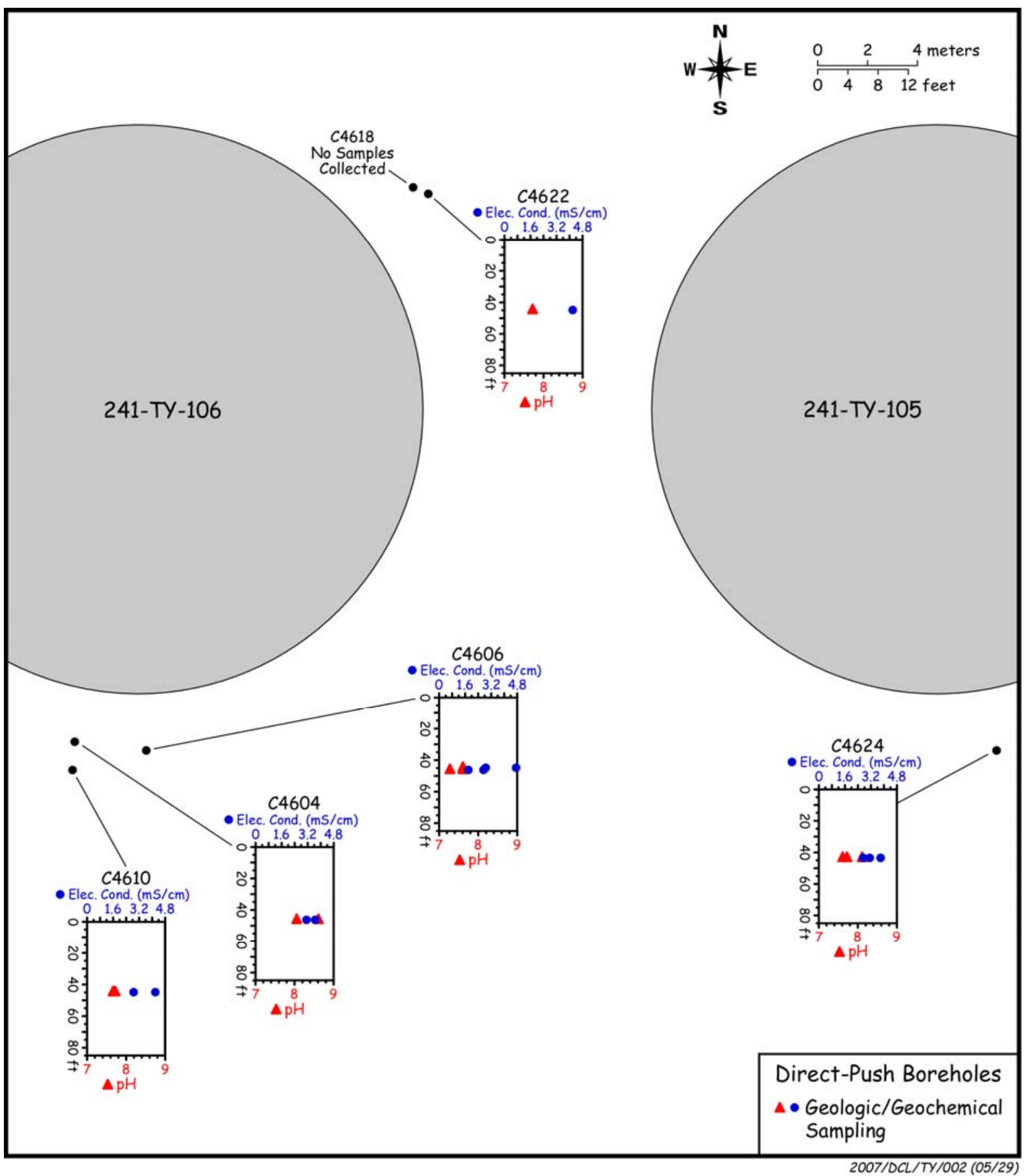

Figure 4.2. $\mathrm{pH}$ for 1:1 Sediment:Water Extracts and Dilution-Corrected EC Values from TY Tank Farm

\subsubsection{Composition of the 1:1 Sediment:Water Extracts from the TY Tank Farm Core and Grab Samples}

The water extract values for the major anions, cations, and several trace constituents are discussed in this section. The anion data are tabulated in Table 4.3 and Figures 4.3 through 4.4 in units of mass per gram of dry sediment. Two of the 1:1 sediment:water extracts contained slightly elevated concentrations 
of fluoride (greater than $1 \mu \mathrm{g} / \mathrm{g}$ ) compared to the average fluoride concentration of all 12 samples $(0.58 \mu \mathrm{g} / \mathrm{g})$. The average 1:1 sediment:water extract fluoride value for the TY Tank Farm probe holes was comparable to the average concentration of $0.60 \mu \mathrm{g} / \mathrm{g}$ found in borehole $299-\mathrm{W} 10-27$. The probe holes containing the samples with elevated fluoride were C4610 (A-sleeve) and C4606 (C-sleeve), which are both located at the south end of tank 241-TY-106. The A-sleeve is the first liner placed in the sampler behind the nose cone and represents the deepest core sample collected from the hole. Interestingly, tank 241-TY-103 was the only tank leak within the TY tank farm reported to contain significant fluoride $(0.123 \mathrm{M})$ (Cantrell et al. 2007). Two of the 1:1 sediment:water extracts contained elevated chloride concentrations (greater than $3 \mu \mathrm{g} / \mathrm{g}$ ) compared to the average chloride concentration of all 12 samples $(1.38 \mu \mathrm{g} / \mathrm{g})$, which was comparable to the average chloride concentration of $0.90 \mu \mathrm{g} / \mathrm{g}$ found in the background borehole (299-W10-27). These two samples were from probe holes C4604 (A-sleeve) and C4624 (A-sleeve), which are located south of tanks 241-TY-106 (C4604) and 241-TY-105 (C4624).

Both tanks 241-T-105 and 241-TY-106 held waste containing approximately $0.1 \mathrm{M}$ chloride, although the leak at tank TY-105 released approximately twice as much volume $(1.32 \mathrm{E}+05 \mathrm{~L})$ to the vadose zone than the leak from tank TY-106 (7.57E+04 L) (Cantrell et al. 2007). Water-extractable nitrate was highest (approximately $6 \mu \mathrm{g} / \mathrm{g}$ of dry sediment) in a sample from probe hole C4606, which is just south of tank 241-TY-106, compared to an average nitrate value for all 12 samples of $2.8 \mu \mathrm{g} / \mathrm{g}$. The nitrate values for the 1:1 sediment:water extracts for the TY Tank Farm direct push samples were, on average, slightly higher than values found in borehole 299-W10-27 $(1.5 \mu \mathrm{g} / \mathrm{g})$. All of the tank leaks within the TY tank farm contained in excess of $2 \mathrm{M}$ nitrate-nitrite (Cantrell et al. 2007). The A-sleeve 1:1 sediment:water extract from probe hole C4604 (located just south of 241-TY-106) contained elevated sulfate (greater than $90 \mu \mathrm{g} / \mathrm{g})$, compared to the average of all 12 samples $(24 \mu \mathrm{g} / \mathrm{g})$. The average sulfate concentration for the 1:1 sediment:water extracts from the TY Tank Farm direct push was approximately a factor of two higher than the average concentration from background borehole 299-W10-27 $(11 \mu \mathrm{g} / \mathrm{g})$. The majority of the samples did not contain quantifiable amounts of water-extractable phosphate.

The water-extractable major cations in the TY Tank Farm probe hole sediments are tabulated in Table 4.4 and Figure 4.5 in units of mass per gram of sediment on a dry weight basis. The A-sleeve from push hole C4604 (located south of tank 241-TY-106) contained elevated levels of several water-extractable cations. Specifically, the calcium concentration $(82 \mu \mathrm{g} / \mathrm{g}))$ in the A-sleeve from C4604 was significantly higher than the average calcium concentration of all the samples measured $(15 \mu \mathrm{g} / \mathrm{g})$; potassium $(21 \mu \mathrm{g} / \mathrm{g})$ was elevated compared to the average potassium concentration of all the samples measured $(6.4 \mu \mathrm{g} / \mathrm{g})$; strontium $(0.3 \mu \mathrm{g} / \mathrm{g})$, was a factor of five higher than the average strontium concentration of all the samples measured $(0.06 \mu \mathrm{g} / \mathrm{g})$ and sodium $(79 \mu \mathrm{g} / \mathrm{g})$ was elevated compared to the average sodium concentration of all the samples measured $(26 \mu \mathrm{g} / \mathrm{g})$. All of the TY farm tank leaks contained in excess of $4 \mathrm{M}$ sodium and insignificant concentrations of calcium, magnesium, and potassium (Cantrell et al. 2007). It was surprising to find elevated calcium, magnesium, and sodium together in the same sample, since the sodium would typically drive the divalent cations off the exchange sites. The concentrations of these cations from the A-sleeve material of push hole C4604 were significantly higher than those found in the shoe material from the same push hole. Further, this disparity was consistent with the $\mathrm{pH}$ and $\mathrm{EC}$ measurements from these two samples and was likely an artifact of sampling limitations (i.e., poor recovery in combination with slough). Conversely, water-extractable magnesium was low for the A-sleeve $(0.01 \mu \mathrm{g} / \mathrm{g})$ and shoe $(0.6 \mu \mathrm{g} / \mathrm{g})$ materials from push hole C4604, as well as for the B-sleeve $(0.6 \mu \mathrm{g} / \mathrm{g})$ material from push hole $\mathrm{C} 4624$. The A-sleeve material from push hole C4624 contained an elevated concentration of magnesium $(2.4 \mu \mathrm{g} / \mathrm{g})$, as did the shoe material for push hole C4606 $(2.2 \mu \mathrm{g} / \mathrm{g})$. With the exception of the A-liner sample from direct push hole C4604, sodium was the dominant water extractable cation in the Sediment:water extract samples; however, the 
A-liner from push hole C4604 still contained significantly elevated water-extractable sodium. Based on these data, there are signs of cation exchange by high sodium containing tank waste in all of the probe holes emplaced around tank 241-TY-106.

Table 4.3. Water-Extractable Anions in the TY Tank Farm Core and Grab Samples ( $\mu \mathrm{g} / \mathrm{g}$ dry sediment)

\begin{tabular}{|c|c|c|c|c|c|c|c|}
\hline $\begin{array}{c}\text { Sample } \\
\text { ID }\end{array}$ & $\begin{array}{c}\text { Probe Hole } \\
\text { ID } \\
\end{array}$ & $\begin{array}{c}\text { Mid-Depth } \\
\text { ft bgs }\end{array}$ & $\begin{array}{c}\text { Fluoride } \\
\mu \mathrm{g} / \mathrm{g}\end{array}$ & $\begin{array}{c}\text { Chloride } \\
\mu \mathrm{g} / \mathrm{g}\end{array}$ & $\begin{array}{c}\text { Nitrate } \\
\mu \mathrm{g} / \mathrm{g}\end{array}$ & $\begin{array}{c}\text { Sulfate } \\
\mu \mathrm{g} / \mathrm{g}\end{array}$ & $\begin{array}{c}\text { Phosphate } \\
\mu \mathrm{g} / \mathrm{g}\end{array}$ \\
\hline S06001-1A & C4604 & 44.95 & $6.14 \mathrm{E}-01$ & $3.78 \mathrm{E}+00$ & $3.16 \mathrm{E}+00$ & $9.43 E+01$ & 6.80E-01 \\
\hline S06001-1 & C4604 & Not Reported & $2.89 \mathrm{E}-01$ & $5.38 \mathrm{E}-01$ & $2.15 \mathrm{E}+00$ & $5.42 \mathrm{E}+00$ & $<5.62 \mathrm{E}-01$ \\
\hline S06001-2B & C4624 & 42.10 & $9.90 \mathrm{E}-01$ & $1.36 \mathrm{E}+00$ & $<4.33 E-01$ & $3.63 \mathrm{E}+01$ & $<5.05 \mathrm{E}-01$ \\
\hline S06001-2A & C4624 & 42.50 & $3.50 \mathrm{E}-01$ & $3.46 \mathrm{E}+00$ & $3.04 \mathrm{E}+00$ & $4.49 \mathrm{E}+01$ & $<5.05 \mathrm{E}-01$ \\
\hline S06001-2 & C4624 & 43.05 & $2.80 \mathrm{E}-01$ & $6.85 \mathrm{E}-01$ & $2.49 \mathrm{E}+00$ & $1.98 \mathrm{E}+01$ & $<5.05 \mathrm{E}-01$ \\
\hline S06001-3A & $\mathrm{C} 4610$ & 43.80 & $1.30 \mathrm{E}+00$ & $1.68 \mathrm{E}+00$ & $2.96 \mathrm{E}+00$ & $3.40 \mathrm{E}+01$ & $<5.05 \mathrm{E}-01$ \\
\hline S06001-3 & C4610 & 44.21 & $6.10 \mathrm{E}-01$ & $8.06 \mathrm{E}-01$ & $2.76 \mathrm{E}+00$ & $1.94 \mathrm{E}+01$ & $<5.05 \mathrm{E}-01$ \\
\hline S06001-4C & C4606 & 44.38 & $1.09 \mathrm{E}+00$ & $1.18 \mathrm{E}+00$ & $1.54 \mathrm{E}+00$ & $1.50 \mathrm{E}+01$ & $<5.05 \mathrm{E}-01$ \\
\hline S06001-4B & C4606 & 44.67 & $3.93 \mathrm{E}-01$ & $8.82 \mathrm{E}-01$ & $2.98 \mathrm{E}+00$ & $8.78 \mathrm{E}+00$ & $<5.05 \mathrm{E}-01$ \\
\hline S06001-4A & C4606 & 45.17 & $3.74 \mathrm{E}-01$ & $7.23 \mathrm{E}-01$ & $3.76 \mathrm{E}+00$ & $1.11 \mathrm{E}+01$ & $<5.05 \mathrm{E}-01$ \\
\hline S06001-4A DUP & C4606 & 45.17 & $3.58 \mathrm{E}-01$ & $6.48 \mathrm{E}-01$ & $3.22 \mathrm{E}+00$ & $6.93 \mathrm{E}+00$ & $<5.05 \mathrm{E}-01$ \\
\hline S06001-4 & $\mathrm{C} 4606$ & 45.71 & $3.49 \mathrm{E}-01$ & $1.09 \mathrm{E}+00$ & $6.15 E+00$ & $8.72 \mathrm{E}+00$ & $<5.05 \mathrm{E}-01$ \\
\hline S06001-5 & C4622 & 43.65 & $5.46 \mathrm{E}-01$ & $1.12 \mathrm{E}+00$ & $1.23 \mathrm{E}+00$ & $1.25 \mathrm{E}+01$ & $<5.05 \mathrm{E}-01$ \\
\hline \multicolumn{8}{|c|}{$\begin{array}{l}\text { Bold values denote elevated concentrations. } \\
\text { Italicized values denote low concentrations. } \\
\text { Less than values indicate the instrument returned a negative value. } \\
\text { NR indicates the information was not reported on the chain of custody. } \\
\text { Shaded cells indicate grab samples. }\end{array}$} \\
\hline
\end{tabular}

Table 4.4. Water-Extractable Major Cations in the TY Tank Farm Core and Grab Samples $(\mu \mathrm{g} / \mathrm{g}$ dry sediment)

\begin{tabular}{|c|c|c|c|c|c|c|c|}
\hline $\begin{array}{l}\text { Sample } \\
\text { ID }\end{array}$ & $\begin{array}{c}\text { Probe Hole } \\
\text { ID }\end{array}$ & $\begin{array}{c}\text { Mid-Depth } \\
\text { ft bgs }\end{array}$ & $\begin{array}{c}\text { Calcium } \\
\mu \mathrm{g} / \mathrm{g}\end{array}$ & $\begin{array}{c}\text { Potassium } \\
\mu \mathrm{g} / \mathrm{g}\end{array}$ & $\begin{array}{c}\text { Magnesium } \\
\mu \mathrm{g} / \mathrm{g}\end{array}$ & $\begin{array}{c}\text { Strontium } \\
\mu \mathrm{g} / \mathrm{g}\end{array}$ & $\begin{array}{c}\text { Sodium } \\
\mu \mathrm{g} / \mathrm{g}\end{array}$ \\
\hline S06001-1A & $\mathrm{C} 4604$ & 44.95 & $8.22 \mathrm{E}+01$ & $2.12 \mathrm{E}+01$ & $(1.35 \mathrm{E}-02)$ & $2.86 \mathrm{E}-01$ & $7.87 \mathrm{E}+01$ \\
\hline S06001-1 & C4604 & NR & $3.46 E+00$ & $(6.65 \mathrm{E}+00)$ & $6.20 E-01$ & $(1.76 \mathrm{E}-02)$ & $3.49 \mathrm{E}+01$ \\
\hline S06001-2B & C4624 & 42.10 & $5.88 \mathrm{E}+00$ & $(4.66 \mathrm{E}+00)$ & $6.49 E-01$ & $(2.76 \mathrm{E}-02)$ & $2.92 \mathrm{E}+01$ \\
\hline S06001-2A & C4624 & 42.50 & $1.55 \mathrm{E}+01$ & $(5.74 \mathrm{E}+00)$ & $2.42 \mathrm{E}+00$ & $7.55 \mathrm{E}-02$ & $1.89 \mathrm{E}+01$ \\
\hline S06001-2 & $\mathrm{C} 4624$ & 43.05 & $1.01 \mathrm{E}+01$ & $(5.53 \mathrm{E}+00)$ & $1.68 \mathrm{E}+00$ & $6.07 \mathrm{E}-02$ & $1.43 \mathrm{E}+01$ \\
\hline S06001-3A & $\mathrm{C} 4610$ & 43.80 & $7.49 \mathrm{E}+00$ & $(5.72 \mathrm{E}+00)$ & $1.53 \mathrm{E}+00$ & $(4.08 \mathrm{E}-02)$ & $3.31 \mathrm{E}+01$ \\
\hline S06001-3 & $\mathrm{C} 4610$ & 44.21 & $8.68 \mathrm{E}+00$ & $(4.53 \mathrm{E}+00)$ & $1.56 \mathrm{E}+00$ & $(4.37 \mathrm{E}-02)$ & $1.73 \mathrm{E}+01$ \\
\hline S06001-4C & $\mathrm{C} 4606$ & 44.38 & $8.02 \mathrm{E}+00$ & $(5.50 \mathrm{E}+00)$ & $1.50 \mathrm{E}+00$ & $(3.91 \mathrm{E}-02)$ & $2.65 \mathrm{E}+01$ \\
\hline S06001-4B & C4606 & 44.67 & $9.61 \mathrm{E}+00$ & $(4.84 \mathrm{E}+00)$ & $1.42 \mathrm{E}+00$ & $5.24 \mathrm{E}-02$ & $1.54 \mathrm{E}+01$ \\
\hline S06001-4A & $\mathrm{C} 4606$ & 45.17 & $1.03 \mathrm{E}+01$ & $(4.38 \mathrm{E}+00)$ & $1.84 \mathrm{E}+00$ & $5.68 \mathrm{E}-02$ & $1.36 \mathrm{E}+01$ \\
\hline \begin{tabular}{|l|} 
S06001-4A DUP \\
\end{tabular} & $\mathrm{C} 4606$ & 45.17 & $8.37 \mathrm{E}+00$ & $(4.14 \mathrm{E}+00)$ & $1.41 \mathrm{E}+00$ & (4.48E-02) & $1.32 \mathrm{E}+01$ \\
\hline S06001-4 & $\mathrm{C} 4606$ & 45.71 & $1.19 \mathrm{E}+01$ & $(4.64 \mathrm{E}+00)$ & $2.23 E+00$ & $6.18 \mathrm{E}-02$ & $1.41 \mathrm{E}+01$ \\
\hline S06001-5 & C4622 & 43.65 & $7.11 \mathrm{E}+00$ & $(5.87 \mathrm{E}+00)$ & $1.18 \mathrm{E}+00$ & $(3.35 \mathrm{E}-02)$ & $2.47 \mathrm{E}+01$ \\
\hline \multicolumn{8}{|c|}{$\begin{array}{l}\text { Bold values denote elevated concentrations. } \\
\text { Italicized values denote low concentrations. } \\
\text { Parentheses indicate reported value was less than the limit of quantification for the analysis. } \\
\text { NR indicates that the information was not reported on the chain of custody. } \\
\text { Shaded cells indicate grab samples. }\end{array}$} \\
\hline
\end{tabular}




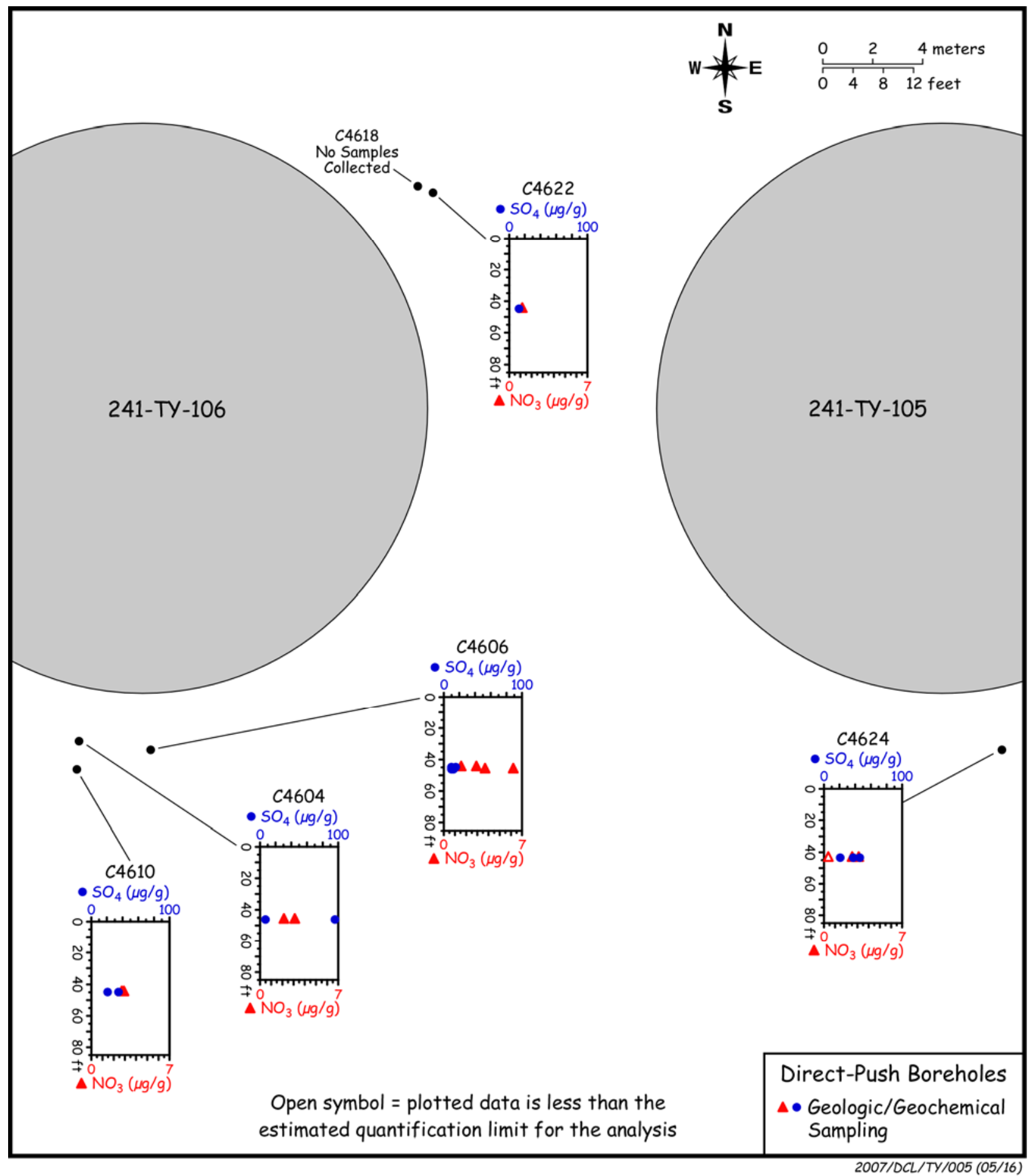

Figure 4.3. 1:1 Sediment:Water-Extractable Nitrate and Sulfate Data from the TY Tank Farm Direct Push Samples 


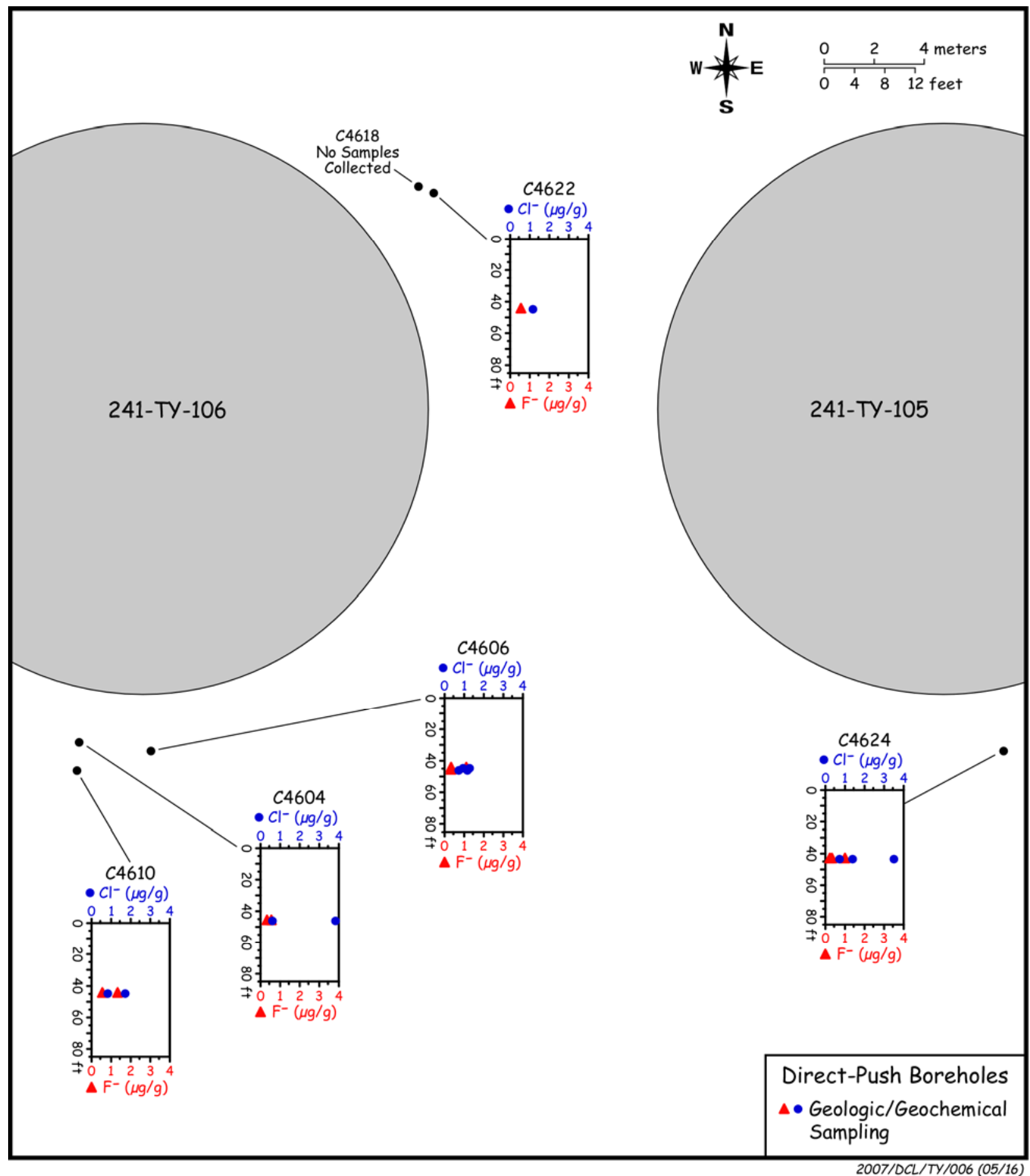

Figure 4.4. 1:1 Sediment:Water-Extractable Chloride and Fluoride Data from the TY Tank Farm Direct Push Samples 


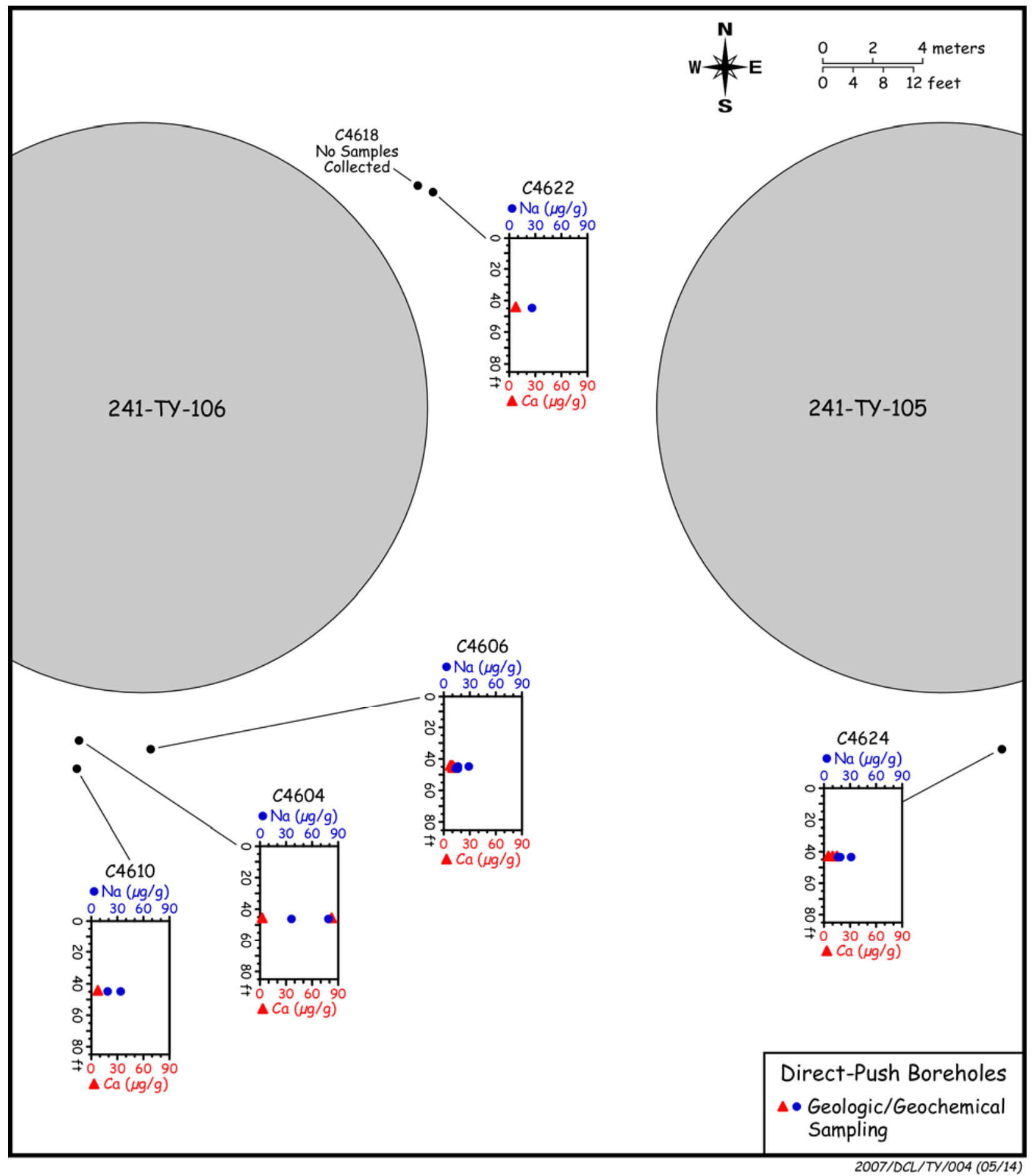

Figure 4.5. 1:1 Sediment:Water-Extractable Sodium and Calcium Data from the TY Tank Farm Direct Push Samples 
The water-extractable aluminum, iron, silicon, and sulfur in the TY direct push sediments are shown in Table 4.5. The sulfur data were converted to water-extractable sulfur as sulfate so that the results could be compared to the IC data presented in Table 4.3. The water-soluble aluminum was elevated (above the limit of detection) in samples from probe holes C4604 and C4610, which were both emplaced to the south of tank 241-TY-106. It appears that these elevated values of aluminum are a result of some chemical reactions (dissolution/precipitation) between alkaline tank fluids and native sediments that formed precipitates of amorphous aluminum phases that are more water soluble than crystalline aluminum-rich mineral phases in the native sediments. The A-sleeve material from borehole $\mathrm{C} 4606$ also contained elevated water-extractable sulfur (reported as sulfate in Table 4.5) and silicon. These results further support the hypothesis that the vadose zone sediments in the vicinity of this probe hole have been chemically altered due to interaction with tank-related waste. The agreement between directly measured sulfate in the water extracts using ion chromatography and indirectly by converting the ICP measurements for sulfur to sulfate was very good (Tables 4.3 and 4.5). Besides validating the ion chromatography data, we can state that the water-extractable sulfur was in fact sulfate.

The water extract data for potentially mobile metals, such as technetium-99, uranium-238, chromium, molybdenum, and ruthenium $(\mathrm{Ru})$ are shown in Table 4.6. Additionally, the water-extractable uranium238 is plotted as a function of depth in Figure 4.6. Not a single sample collected from the five probe holes (twelve samples total) contained water-leachable technetium-99. Elevated water-leachable uranium-238 was only found in a single sample (S06001-1) from probe hole C4604, which was emplaced just south of tank $241-\mathrm{TY}-106$. At only $7.20 \mathrm{E}-03 \mu \mathrm{g} / \mathrm{g}$, this sample was elevated by approximately a factor of 10 when compared to the average water-extractable uranium concentration found in sediment from borehole 299-W10-27 (9.97E-4 $\mu \mathrm{g} / \mathrm{g})$. This sample did not have an elevated porewater alkalinity; however, sample S06001-1A, which was collected just shallower than sample S06001-1, had a porewater alkalinity of $113 \mathrm{meq} / \mathrm{L}$, which was elevated by a factor of three above the average porewater alkalinity measured in all of the TY direct push samples, as well as the highest measured $\mathrm{pH}$ value (8.63). Therefore, it is possible that the slightly elevated uranium observed in sample S06001-1 could be an artifact of uranyl-carbonate complexation of naturally occurring labile uranium rather than soluble tankwaste-related contaminant uranium.

Elevated water-leachable chromium $(2.64 \mathrm{E}-01 \mu \mathrm{g} / \mathrm{g})$ was only observed in sample S06001-1A collected from probe hole C4604. For comparative purposes, the average water-leachable chromium value for all of the remaining TY direct push samples was below the limit of quantification for the analysis (less than $1.25 \mathrm{E}-2 \mu \mathrm{g} / \mathrm{g}$ ). Four samples appeared to have slightly elevated concentrations of water-leachable molybdenum (1.17E-01 to $1.66 \mathrm{E}-01 \mu \mathrm{g} / \mathrm{g}$ ) compared to the average water-leachable molybdenum concentration in samples from borehole 299-10-27 (5.72E-03 $\mu \mathrm{g} / \mathrm{g})$. The samples containing elevated molybdenum came from probe holes C4604, C4610, and C4626, and could be a result of the dissolution of naturally present minerals via an alkaline tank waste solution. Once dissolved, the molybdenum would be quite mobile and could travel a significant distance from the point of discharge. None of the samples analyzed contained quantifiable concentrations of water-extractable ruthenium. However, this was not surprising given the lack of measurable technetium-99 in these samples. 
Table 4.5. Water-Extractable Cations in the TY Tank Farm Core and Grab Samples ( $\mu \mathrm{g} / \mathrm{g}$ dry sediment)

\begin{tabular}{|c|c|c|c|c|c|c|}
\hline $\begin{array}{l}\text { Sample } \\
\text { ID }\end{array}$ & $\begin{array}{c}\text { Probe Hole } \\
\text { ID }\end{array}$ & $\begin{array}{c}\text { Mid-Depth } \\
\text { ft bgs }\end{array}$ & $\begin{array}{c}\text { Aluminum } \\
\mu \mathrm{g} / \mathrm{g}\end{array}$ & $\begin{array}{l}\text { Iron } \\
\mu \mathrm{g} / \mathrm{g}\end{array}$ & $\begin{array}{c}\text { Sulfur as } \mathrm{SO}_{4}{ }^{2-} \\
\mu \mathrm{g} / \mathrm{g}\end{array}$ & $\begin{array}{c}\text { Silicon } \\
\mu \mathrm{g} / \mathrm{g}\end{array}$ \\
\hline S06001-1A & C4604 & 44.95 & 3.68E-01 & $(2.07 E-03)$ & $9.69 \mathrm{E}+01$ & $3.80 \mathrm{E}+01$ \\
\hline S06001-1 & $\mathrm{C} 4604$ & NR & $(5.46 \mathrm{E}-02)$ & $6.34 \mathrm{E}-02$ & $6.09 \mathrm{E}+00$ & $1.71 \mathrm{E}+01$ \\
\hline S06001-2B & $\mathrm{C} 4624$ & 42.10 & $(5.85 \mathrm{E}-02)$ & $6.32 \mathrm{E}-02$ & $3.69 \mathrm{E}+01$ & $1.42 \mathrm{E}+01$ \\
\hline S06001-2A & C4624 & 42.50 & $(2.73 \mathrm{E}-02)$ & $(2.06 E-02)$ & $4.62 \mathrm{E}+01$ & $2.21 \mathrm{E}+01$ \\
\hline S06001-2 & C4624 & 43.05 & $(3.25 \mathrm{E}-02)$ & $3.91 \mathrm{E}-02$ & $2.21 \mathrm{E}+01$ & $1.40 \mathrm{E}+01$ \\
\hline S06001-3A & $\mathrm{C} 4610$ & 43.80 & 2.08E-01 & $1.51 \mathrm{E}-01$ & $3.66 \mathrm{E}+01$ & $1.06 \mathrm{E}+01$ \\
\hline S06001-3 & $\mathrm{C} 4610$ & 44.21 & $(8.88 \mathrm{E}-02)$ & $7.88 \mathrm{E}-02$ & $2.07 \mathrm{E}+01$ & $1.07 \mathrm{E}+01$ \\
\hline S06001-4C & $\mathrm{C} 4606$ & 44.38 & $(9.73 \mathrm{E}-02)$ & $1.03 \mathrm{E}-01$ & $1.70 \mathrm{E}+01$ & $1.18 \mathrm{E}+01$ \\
\hline S06001-4B & $\mathrm{C} 4606$ & 44.67 & $(5.94 \mathrm{E}-02)$ & $6.65 \mathrm{E}-02$ & $9.90 \mathrm{E}+00$ & $1.41 \mathrm{E}+01$ \\
\hline S06001-4A & $\mathrm{C} 4606$ & 45.17 & $(5.29 \mathrm{E}-02)$ & $5.58 \mathrm{E}-02$ & $1.13 \mathrm{E}+01$ & $1.36 \mathrm{E}+01$ \\
\hline S06001-4A DUP & $\mathrm{C} 4606$ & 45.17 & $(3.55 \mathrm{E}-02)$ & $4.35 \mathrm{E}-02$ & $6.99 \mathrm{E}+00$ & $1.33 \mathrm{E}+01$ \\
\hline S06001-4 & C4606 & 45.71 & $(8.59 \mathrm{E}-02)$ & $1.25 \mathrm{E}-01$ & $9.03 \mathrm{E}+00$ & $1.28 \mathrm{E}+01$ \\
\hline S06001-5 & C4622 & 43.65 & (5.18E-02) & $5.58 \mathrm{E}-02$ & $1.35 \mathrm{E}+01$ & $1.67 \mathrm{E}+01$ \\
\hline \multicolumn{7}{|c|}{$\begin{array}{l}\text { Bold values denote elevated concentrations. } \\
\text { Italicized values denote low concentrations. } \\
\text { Parentheses indicate reported value was less than the limit of quantification for the analysis. } \\
\text { NR indicates the information was not reported on the chain of custody. } \\
\text { Shaded cells indicate grab samples. }\end{array}$} \\
\hline
\end{tabular}

The mobile metal data do not indicate the presence of a significant amount of tank-related waste constituents in any of the TY direct push probe holes. Given the considerable amount of time that has elapsed since the 241-TY-105 and 241-TY-106 tanks were purported to have leaked, natural recharge could have pushed the mobile contaminants deep into the vadose, making their detection via shallow direct push sampling difficult.

\subsubsection{Vadose Zone Porewater Chemical Composition}

The 1:1 water extract data was processed to derive the pore water composition of the existing moisture in vadose zone sediments so that electrical balances (anions vs. cation) of the porewater could be evaluated. From knowledge of the moisture content of the sediment samples taken from the liners of each direct push sampler and the grab samples, the amount of de-ionized water that would be needed to make the water extract exactly one part water (total of native pore water and added de-ionized water) to one part by weight dry sediment was calculated. The ratio of the total volume of water in the extract to the native mass of pore water is the dilution factor. An assumption was made that the de-ionized water acted solely as a diluent of the existing pore water and that the de-ionized water did not dissolve any of the solids in the sediments. Thus by correcting for the dilution, an estimate of the actual chemical composition of the native pore-water in the vadose zone sediments could be derived.

The assumption that none of the solid is dissolved during the water extraction process is simplistic. In comparisons of actual vadose zone sediment pore water, which was obtained via ultracentrifugation of sediments, to the dilution-corrected calculated pore waters from both contaminated and uncontaminated sediments from the SX and B-BX Tank Farms (see Serne et al. 2002b, 2002c, 2002d, 2002e, 2002f), it was found that for highly contaminated sediments, the comparison is quite good. For slightly contaminated or uncontaminated sediments, the dilution-corrected water extract data is biased high by a factor of 2 to 7 for many constituents such that the true pore water is less saline. For the TY 
Table 4.6. Water-Extractable Mobile Metals in the TY Tank Farm Core and Grab Samples ( $\mu \mathrm{g} / \mathrm{g}$ dry sediment)

\begin{tabular}{|c|c|c|c|c|c|c|c|c|}
\hline $\begin{array}{c}\text { Sample } \\
\text { ID }\end{array}$ & $\begin{array}{c}\text { Probe Hole } \\
\text { ID }\end{array}$ & $\begin{array}{c}\text { Mid-Depth } \\
\text { ft bgs }\end{array}$ & $\begin{array}{c}\text { Technetium-99 } \\
\text { pCi/g }\end{array}$ & $\begin{array}{c}\text { Uranium-238 } \\
\mu \mathrm{g} / \mathrm{g}\end{array}$ & $\begin{array}{c}\text { Chromium } \\
\mu \mathrm{g} / \mathrm{g}\end{array}$ & $\begin{array}{c}\text { Molybdenum-95 } \\
\mu \mathrm{g} / \mathrm{g}\end{array}$ & $\begin{array}{c}\text { Ruthenium-101 } \\
\mu \mathrm{g} / \mathrm{g}\end{array}$ & $\begin{array}{c}\text { Ruthenium-102 } \\
\mu \mathrm{g} / \mathrm{g}\end{array}$ \\
\hline S06001-1A & C4604 & 44.95 & $<1.70 \mathrm{E}-01$ & $(2.83 \mathrm{E}-06)$ & $2.64 \mathrm{E}-01$ & 1.39E-01 & $(6.69 \mathrm{E}-05)$ & $<5.08 \mathrm{E}-03$ \\
\hline S06001-1 & C4604 & NR & $<1.89 \mathrm{E}-01$ & $7.20 \mathrm{E}-03$ & $(3.35 \mathrm{E}-03)$ & $9.81 \mathrm{E}-03$ & $(4.52 \mathrm{E}-05)$ & $<6.52 \mathrm{E}-03$ \\
\hline S06001-2B & $\mathrm{C} 4624$ & 42.10 & $<1.70 \mathrm{E}-01$ & $3.26 \mathrm{E}-04$ & $(1.25 \mathrm{E}-02)$ & 1.17E-01 & $<1.25 \mathrm{E}-04$ & $<5.20 \mathrm{E}-03$ \\
\hline S06001-2A & $\mathrm{C} 4624$ & 42.50 & $<1.70 \mathrm{E}-01$ & $1.01 \mathrm{E}-03$ & $(1.04 \mathrm{E}-02)$ & $2.78 \mathrm{E}-02$ & $<1.25 \mathrm{E}-04$ & $<5.70 \mathrm{E}-03$ \\
\hline S06001-2 & $\mathrm{C} 4624$ & 43.05 & $<1.70 \mathrm{E}-01$ & $9.50 \mathrm{E}-04$ & $(2.67 \mathrm{E}-03)$ & $1.61 \mathrm{E}-02$ & $(2.19 \mathrm{E}-06)$ & $<5.31 \mathrm{E}-03$ \\
\hline S06001-3A & $\mathrm{C} 4610$ & 43.80 & $<1.70 \mathrm{E}-01$ & $6.66 \mathrm{E}-04$ & $(3.21 \mathrm{E}-03)$ & $1.66 \mathrm{E}-01$ & $(9.17 \mathrm{E}-07)$ & $<5.98 \mathrm{E}-03$ \\
\hline S06001-3 & C4610 & 44.21 & $<1.70 \mathrm{E}-01$ & $7.82 \mathrm{E}-04$ & $(2.70 \mathrm{E}-03)$ & $1.36 \mathrm{E}-01$ & $(9.07 \mathrm{E}-07)$ & $<6.05 \mathrm{E}-03$ \\
\hline S06001-4C & $\mathrm{C} 4606$ & 44.38 & $<1.70 \mathrm{E}-01$ & $1.45 \mathrm{E}-03$ & $(1.08 \mathrm{E}-03)$ & $8.09 \mathrm{E}-02$ & $(6.78 \mathrm{E}-07)$ & $<6.61 \mathrm{E}-03$ \\
\hline S06001-4B & C4606 & 44.67 & $<1.70 \mathrm{E}-01$ & $1.29 \mathrm{E}-03$ & $(1.59 \mathrm{E}-03)$ & $1.64 \mathrm{E}-02$ & $<1.25 \mathrm{E}-04$ & $<5.72 \mathrm{E}-03$ \\
\hline S06001-4A & C4606 & 45.17 & $<1.70 \mathrm{E}-01$ & $2.01 \mathrm{E}-03$ & $(4.60 \mathrm{E}-03)$ & $1.60 \mathrm{E}-02$ & $<1.25 \mathrm{E}-04$ & $<5.44 \mathrm{E}-03$ \\
\hline S06001-4A DUP & C4606 & 45.17 & $<1.70 \mathrm{E}-01$ & $1.29 \mathrm{E}-03$ & $(2.18 \mathrm{E}-03)$ & $1.48 \mathrm{E}-02$ & $(6.15 \mathrm{E}-07)$ & $<5.92 \mathrm{E}-03$ \\
\hline S06001-4 & C4606 & 45.71 & $<1.70 \mathrm{E}-01$ & $1.76 \mathrm{E}-03$ & $(5.47 \mathrm{E}-03)$ & $1.97 \mathrm{E}-02$ & $(1.61 \mathrm{E}-06)$ & $<6.57 \mathrm{E}-03$ \\
\hline S06001-5 & $\mathrm{C} 4622$ & 43.65 & $<1.70 \mathrm{E}-01$ & $1.18 \mathrm{E}-03$ & $(7.06 \mathrm{E}-03)$ & $6.09 \mathrm{E}-02$ & $<1.25 \mathrm{E}-04$ & $<5.22 \mathrm{E}-03$ \\
\hline
\end{tabular}

Bold values denote elevated concentrations.

Parentheses indicate reported value was less than the limit of quantification for the analysis.

Less than values indicate the instrument returned a negative value.

NR indicates the information was not reported on the chain of custody.

Shaded cells indicate grab samples. 


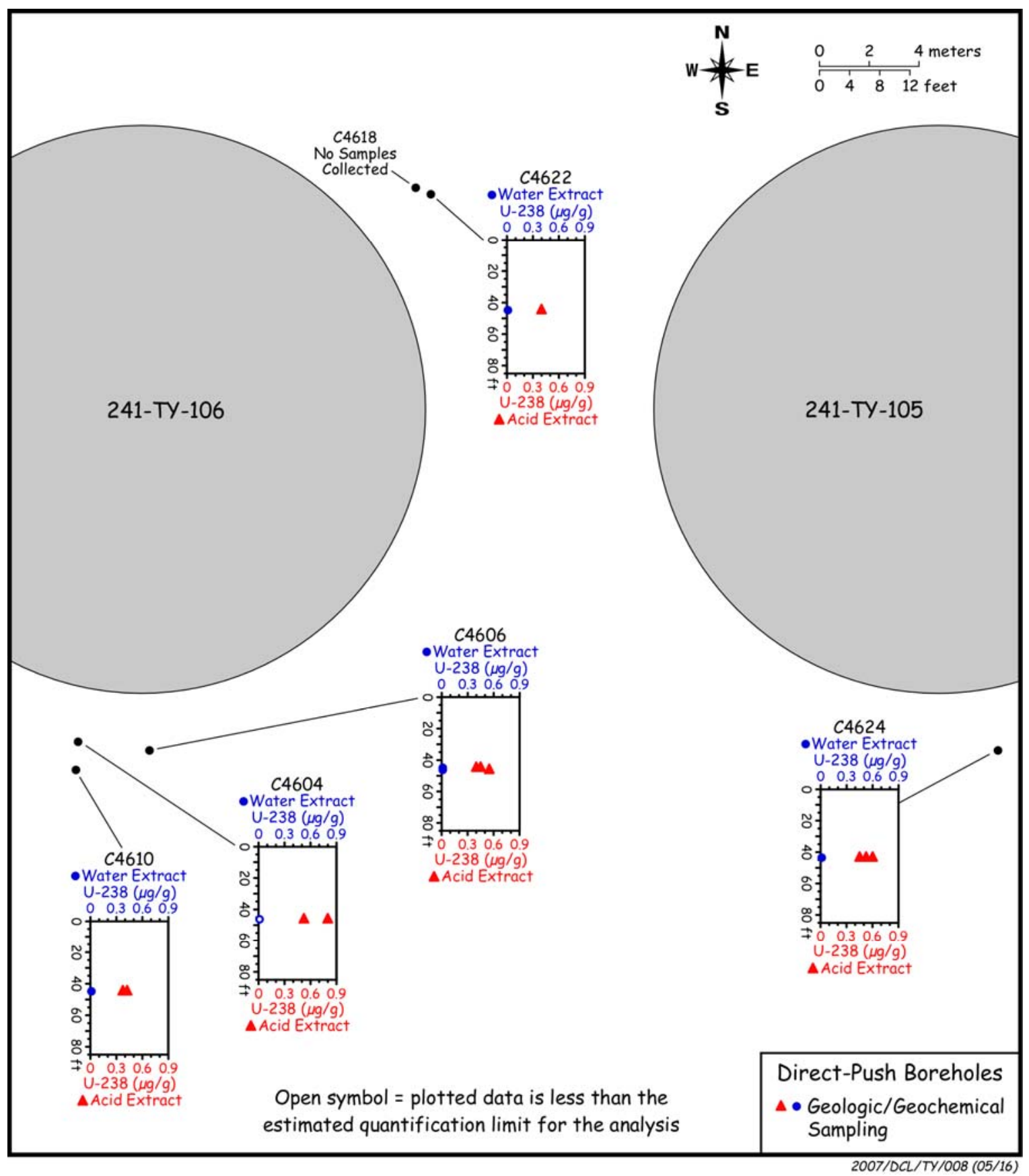

Figure 4.6. 1:1 Sediment:Water-Extractable and 8M Nitric Acid Extractable Uranium-238 Data from the TY Tank Farm Direct Push Samples

direct push data set, sufficient sample material was not available to enable the collection of actual porewater via ultracentrifugation. Therefore, it is assumed that the derived pore water concentrations for the TY direct push samples are slightly biased toward higher concentrations.

Tables 4.7 through 4.10 show the derived pore water composition of key constituents in meq/L and Figure 4.7 shows the porewater corrected alkalinity as $\mathrm{CaCO}_{3}$ in units of $\mathrm{mg} / \mathrm{L}$. Sample S06001-1A was the only sediment sample tested that contained significantly more dissolved salts (approximately four 
times more than the average for all of the samples measured) than the rest of the samples analyzed as part of this study. This sample, which was collected directly south of tank 241-TY-106, contained $155 \mathrm{meq} / \mathrm{L}$ anions vs. $158 \mathrm{meq} / \mathrm{L}$ cations. Sample S06001-1A consisted of $80.5 \mathrm{meq} / \mathrm{L}$ calcium, $67.2 \mathrm{meq} / \mathrm{L}$ sodium, $10.6 \mathrm{meq} / \mathrm{L}$ potassium, and trace amounts of magnesium $(0.022 \mathrm{meq} / \mathrm{L})$. The cation charge for this sample was compensated primarily by bicarbonate $(113 \mathrm{meq} / \mathrm{L})$ with lesser amounts of sulfate (38.6 meq $/ \mathrm{L})$, chloride $(2.12 \mathrm{meq} / \mathrm{L})$, nitrate $(0.999 \mathrm{meq} / \mathrm{L})$, fluoride $(0.635 \mathrm{meq} / \mathrm{L})$ and phosphate $(0.422 \mathrm{meq} / \mathrm{L})$. These concentrations are very dilute compared to the vadose zone pore waters found at the SX and BX tank farms, where the total dissolved salt loads were as high as 7,000 to 17,000 and $1,000 \mathrm{meq} / \mathrm{L}$, respectively. The most concentrated pore waters below tank T-106 ranged from 200 to $250 \mathrm{meq} / \mathrm{L}$ each for cations and anions (total $\sim 450$ to $500 \mathrm{meq} / \mathrm{L}$ ) and below tank TX-107, the most concentrated pore water had 850 total $\mathrm{meq} / \mathrm{L}$.

The remaining TY direct push sediments contained relatively low dissolved salt loads, which ranged from a low of $33.2 \mathrm{meq} / \mathrm{L}$ total (anions and cations) for sample S06001-4 to a high of $88.2 \mathrm{meq} / \mathrm{L}$ for sample S06001-4C. Both of these samples were collected south of tank 241-TY-106 and west of probe hole C4604. Probe hole C4606 was the only location where material was retrieved from the shoe and all three of the liners. Considering that the shoe was collected furthest below ground surface, while the S06001-4C was the shallowest sample collected, it appears that a depth-dependent dissolved salt profile could be present at this location. However, when the relatively dilute dissolved salt loads in these samples are compared with the average total dissolved salt load in the ostensibly uncontaminated 299-W10-27 (366 meq/L), it is difficult to claim that the observed depth-dependent total pore water salt profile is real and not an artifact of sampling depth (i.e., at the interface between the backfill and Hanford formation).

Overall, the calculated charge balance between cations and anions for all of the samples was quite good (less than 15\% difference for most of the samples analyzed). However, samples S06001-2, S06001-4A, and S06001-4A Dup all contained approximately 20\% less dissolved cations than anions. Based on comparison of this data, it appears that either the bicarbonate measurement for these samples is biased high, or analyses have not accounted for a dissolved metal that is present in sufficient quantity to properly balance the electrical charge of these samples.

Sodium was present as the dominant cation in all but two of the samples analyzed. Samples S06001-1A and S06001-1, both from probe hole C4606, contained calcium as the dominant cation. Bicarbonate (measured via titration) was the primary anionic species in all of the samples analyzed. The lack of samples containing calcium as the dominant cation indicates that the samples in this region have been impacted by a sodium-bearing waste fluid. The source(s) appears to be a moderately concentrated sodium-bearing waste solution that has displaced the natural divalent cations from the sediment cation exchange sites in the sediments. The total vertical extent of the ion exchange front is unknown due to the lack of sediment samples from deeper in the vadose zone.

As mentioned previously, none of the TY direct push sediment samples contained measurable concentrations of technetium-99. Three of the samples (S06001-1, S06001-4C, and S06001-4A) contained calculated uranium-238 porewater concentrations in excess of the drinking water standard. The maximum concentration of dissolved uranium was found in a sample from borehole C4604 at a concentration of $132 \mu \mathrm{g} / \mathrm{L}$. The other two direct push samples (S06001-4A and S06001-4C), both collected from probe hole $\mathrm{C} 4606$, contained derived pore water uranium concentrations of 31.2 and $34.0 \mu \mathrm{g} / \mathrm{L}$, respectively. 
Table 4.7. Calculated Pore Water Anion Concentrations in the TY Tank Farm Core and Grab Samples

\begin{tabular}{|c|c|c|c|c|c|c|c|c|}
\hline $\begin{array}{c}\text { Sample } \\
\text { ID }\end{array}$ & $\begin{array}{l}\text { Probe } \\
\text { Hole } \\
\text { ID }\end{array}$ & $\begin{array}{l}\text { Mid- } \\
\text { Depth } \\
\text { ft bgs }\end{array}$ & $\begin{array}{l}\text { Fluoride } \\
\text { meq/L }\end{array}$ & $\begin{array}{l}\text { Chloride } \\
\text { meq/L }\end{array}$ & $\begin{array}{l}\text { Nitrate } \\
\mathrm{meq} / \mathrm{L}\end{array}$ & $\begin{array}{l}\text { Sulfate } \\
\mathrm{meq} / \mathrm{L}\end{array}$ & $\begin{array}{c}\text { Phosphate } \\
\text { meq/L }\end{array}$ & $\begin{array}{c}\text { Alkalinity } \\
\text { meq/L }\end{array}$ \\
\hline S06001-1A & C4604 & 44.95 & $6.35 \mathrm{E}-01$ & $2.09 E+00$ & $9.99 \mathrm{E}-01$ & $3.85 \mathrm{E}+01$ & $4.22 \mathrm{E}-01$ & $1.13 \mathrm{E}+02$ \\
\hline S06001-1 & C4604 & NR & $2.79 \mathrm{E}-01$ & $2.79 \mathrm{E}-01$ & $6.35 \mathrm{E}-01$ & $2.07 \mathrm{E}+00$ & $<3.26 \mathrm{E}-01$ & $3.69 \mathrm{E}+01$ \\
\hline S06001-2B & $\mathrm{C} 4624$ & 42.10 & $9.23 \mathrm{E}-01$ & $6.80 \mathrm{E}-01$ & $<1.24 \mathrm{E}-01$ & $1.34 \mathrm{E}+01$ & $<2.83 \mathrm{E}-01$ & $2.02 \mathrm{E}+01$ \\
\hline S06001-2A & C4624 & 42.50 & $2.22 \mathrm{E}-01$ & $1.18 E+00$ & $5.92 \mathrm{E}-01$ & $1.13 \mathrm{E}+01$ & $<1.92 \mathrm{E}-01$ & $1.23 \mathrm{E}+01$ \\
\hline S06001-2 & C4624 & 43.05 & $2.81 \mathrm{E}-01$ & $3.69 \mathrm{E}-01$ & $7.65 \mathrm{E}-01$ & $7.88 \mathrm{E}+00$ & $<3.04 \mathrm{E}-01$ & $2.42 \mathrm{E}+01$ \\
\hline S06001-3A & C4610 & 43.80 & $1.25 \mathrm{E}+00$ & $8.63 \mathrm{E}-01$ & $8.67 \mathrm{E}-01$ & $1.29 \mathrm{E}+01$ & $<2.90 \mathrm{E}-01$ & $2.58 \mathrm{E}+01$ \\
\hline S06001-3 & C4610 & 44.21 & $5.20 \mathrm{E}-01$ & $3.68 \mathrm{E}-01$ & $7.21 \mathrm{E}-01$ & $6.53 \mathrm{E}+00$ & $<2.58 \mathrm{E}-01$ & $1.80 \mathrm{E}+01$ \\
\hline S06001-4C & C4606 & 44.38 & $1.34 \mathrm{E}+00$ & $7.84 \mathrm{E}-01$ & $5.82 \mathrm{E}-01$ & $7.33 \mathrm{E}+00$ & $<3.74 \mathrm{E}-01$ & $3.51 \mathrm{E}+01$ \\
\hline S06001-4B & $\mathrm{C} 4606$ & 44.67 & $3.51 \mathrm{E}-01$ & 4.22E-01 & $8.15 \mathrm{E}-01$ & $3.10 \mathrm{E}+00$ & $<2.71 \mathrm{E}-01$ & $2.17 \mathrm{E}+01$ \\
\hline S06001-4A & C4606 & 45.17 & $3.06 \mathrm{E}-01$ & $3.17 \mathrm{E}-01$ & $9.43 \mathrm{E}-01$ & $3.60 \mathrm{E}+00$ & $<2.48 \mathrm{E}-01$ & $2.06 \mathrm{E}+01$ \\
\hline S06001-4A DUP & C4606 & 45.17 & $2.87 \mathrm{E}-01$ & $2.78 \mathrm{E}-01$ & $7.90 \mathrm{E}-01$ & $2.20 \mathrm{E}+00$ & $<2.43 \mathrm{E}-01$ & $1.95 \mathrm{E}+01$ \\
\hline S06001-4 & C4606 & 45.71 & $1.89 \mathrm{E}-01$ & $3.15 \mathrm{E}-01$ & $1.02 \mathrm{E}+00$ & $1.87 \mathrm{E}+00$ & $<1.64 \mathrm{E}-01$ & $1.41 \mathrm{E}+01$ \\
\hline S06001-5 & C4622 & 43.65 & $6.34 \mathrm{E}-01$ & $6.94 \mathrm{E}-01$ & $4.37 \mathrm{E}-01$ & $5.75 \mathrm{E}+00$ & $<3.52 \mathrm{E}-01$ & $3.27 \mathrm{E}+01$ \\
\hline \multicolumn{9}{|c|}{$\begin{array}{l}\text { Bold values denote elevated concentrations. } \\
\text { Less than values indicate the instrument returned a negative value. } \\
\text { NR indicates the information was not reported on the chain of custody. } \\
\text { Shaded cells indicate grab samples. }\end{array}$} \\
\hline
\end{tabular}

Table 4.8. Calculated Pore Water Cation Concentrations in the TY Tank Farm Direct Push Core and Grab Samples

\begin{tabular}{|c|c|c|c|c|c|c|}
\hline $\begin{array}{l}\text { Sample } \\
\text { ID }\end{array}$ & $\begin{array}{c}\text { Probe Hole } \\
\text { ID }\end{array}$ & $\begin{array}{c}\text { Mid-Depth } \\
\text { ft bgs }\end{array}$ & $\begin{array}{l}\text { Calcium } \\
\text { meq/L }\end{array}$ & $\begin{array}{c}\text { Potassium } \\
\text { meq/L }\end{array}$ & $\begin{array}{c}\text { Magnesium } \\
\text { meq/L }\end{array}$ & $\begin{array}{l}\text { Sodium } \\
\text { meq/L }\end{array}$ \\
\hline S06001-1A & C4604 & 44.95 & 8.05E+01 & $1.06 \mathrm{E}+01$ & $(2.19 \mathrm{E}-02)$ & $6.72 \mathrm{E}+01$ \\
\hline S06001-1 & C4604 & NR & $3.17 \mathrm{E}+00$ & $(3.12 \mathrm{E}+00)$ & $9.36 \mathrm{E}-01$ & $2.79 \mathrm{E}+01$ \\
\hline S06001-2B & C4624 & 42.10 & $5.20 \mathrm{E}+00$ & $(2.11 \mathrm{E}+00)$ & $9.46 \mathrm{E}-01$ & $2.25 \mathrm{E}+01$ \\
\hline \begin{tabular}{|l|} 
S06001-2A \\
\end{tabular} & C4624 & 42.50 & $9.31 \mathrm{E}+00$ & $(1.77 \mathrm{E}+00)$ & $2.40 \mathrm{E}+00$ & $9.93 E+00$ \\
\hline S06001-2 & C4624 & 43.05 & $9.64 \mathrm{E}+00$ & $(2.70 \mathrm{E}+00)$ & $2.63 \mathrm{E}+00$ & $1.19 \mathrm{E}+01$ \\
\hline S06001-3A & C4610 & 43.80 & $6.79 \mathrm{E}+00$ & $(2.66 \mathrm{E}+00)$ & $2.29 \mathrm{E}+00$ & $2.62 \mathrm{E}+01$ \\
\hline S06001-3 & $\mathrm{C} 4610$ & 44.21 & $7.01 \mathrm{E}+00$ & $(1.88 \mathrm{E}+00)$ & $2.08 \mathrm{E}+00$ & $1.22 \mathrm{E}+01$ \\
\hline S06001-4C & C4606 & 44.38 & $9.38 \mathrm{E}+00$ & $(3.30 \mathrm{E}+00)$ & $2.89 \mathrm{E}+00$ & $2.71 \mathrm{E}+01$ \\
\hline S06001-4B & C4606 & 44.67 & $8.13 \mathrm{E}+00$ & $(2.10 \mathrm{E}+00)$ & $1.98 \mathrm{E}+00$ & $1.13 \mathrm{E}+01$ \\
\hline S06001-4A & C4606 & 45.17 & $7.98 \mathrm{E}+00$ & $(1.74 \mathrm{E}+00)$ & $2.35 \mathrm{E}+00$ & $9.18 E+00$ \\
\hline S06001-4A DUP & C4606 & 45.17 & $6.36 \mathrm{E}+00$ & $(1.61 \mathrm{E}+00)$ & $1.76 \mathrm{E}+00$ & $8.72 E+00$ \\
\hline S06001-4 & C4606 & 45.71 & $6.10 \mathrm{E}+00$ & $(1.22 \mathrm{E}+00)$ & $1.88 \mathrm{E}+00$ & $6.30 \mathrm{E}+00$ \\
\hline S06001-5 & C4622 & 43.65 & $7.83 \mathrm{E}+00$ & $(3.31 \mathrm{E}+00)$ & $2.14 \mathrm{E}+00$ & $2.37 \mathrm{E}+01$ \\
\hline \multicolumn{7}{|c|}{$\begin{array}{l}\text { Bold values denote elevated concentrations. } \\
\text { Parentheses indicate reported value was less than the limit of quantification for the analysis. } \\
\text { NR indicates the information was not reported on the chain of custody. } \\
\text { Shaded cells indicate grab samples. }\end{array}$} \\
\hline
\end{tabular}


Table 4.9. Calculated Pore Water Metal Concentrations in the TY Tank Farm Direct Push Core and Grab Samples

\begin{tabular}{|c|c|c|c|c|c|c|}
\hline $\begin{array}{l}\text { Sample } \\
\text { ID }\end{array}$ & $\begin{array}{c}\text { Probe Hole } \\
\text { ID }\end{array}$ & $\begin{array}{l}\text { Mid-Depth } \\
\text { ft bgs }\end{array}$ & $\begin{array}{c}\text { Aluminum } \\
\text { meq/L }\end{array}$ & $\begin{array}{c}\text { Iron } \\
\mathrm{meq} / \mathrm{L}\end{array}$ & $\begin{array}{l}\text { Sulfur } \\
\mathrm{meq} / \mathrm{L}\end{array}$ & $\begin{array}{l}\text { Silicon } \\
\mathrm{meq} / \mathrm{L}\end{array}$ \\
\hline "S06001-1A & בC4604 & 44.95 & 8.02E-01 & (1.46E-03) & "1.19E+02 & $\overline{1.06 E+02}$ \\
\hline S06001-1 & C4604 & NR & $(1.11 \mathrm{E}-01)$ & $4.17 \mathrm{E}-02$ & $6.98 \mathrm{E}+00$ & $4.47 \mathrm{E}+01$ \\
\hline S06001-2B & C4624 & 42.10 & $(1.15 \mathrm{E}-01)$ & $4.01 \mathrm{E}-02$ & $4.08 \mathrm{E}+01$ & $3.59 \mathrm{E}+01$ \\
\hline S06001-2A & C4624 & 42.50 & (3.66E-02) & $(8.88 \mathrm{E}-03)$ & $3.47 \mathrm{E}+01$ & $3.79 \mathrm{E}+01$ \\
\hline S06001-2 & C4624 & 43.05 & $(6.90 \mathrm{E}-02)$ & $2.67 \mathrm{E}-02$ & $2.63 \mathrm{E}+01$ & $3.81 \mathrm{E}+01$ \\
\hline S06001-3A & C4610 & 43.80 & $4.21 \mathrm{E}-01$ & $9.85 E-02$ & $4.14 \mathrm{E}+01$ & $2.74 \mathrm{E}+01$ \\
\hline S06001-3 & C4610 & 44.21 & $(1.60 \mathrm{E}-01)$ & $4.56 \mathrm{E}-02$ & $2.09 \mathrm{E}+01$ & $2.47 \mathrm{E}+01$ \\
\hline S06001-4C & C4606 & 44.38 & $(2.54 \mathrm{E}-01)$ & 8.61E-02 & $2.48 \mathrm{E}+01$ & $3.94 \mathrm{E}+01$ \\
\hline S06001-4B & $\mathrm{C} 4606$ & 44.67 & $(1.12 \mathrm{E}-01)$ & $4.04 \mathrm{E}-02$ & $1.05 \mathrm{E}+01$ & $3.41 \mathrm{E}+01$ \\
\hline S06001-4A & C4606 & 45.17 & $(9.13 \mathrm{E}-02)$ & $3.10 \mathrm{E}-02$ & $1.10 \mathrm{E}+01$ & $3.00 \mathrm{E}+01$ \\
\hline S06001-4A DUP & C4606 & 45.17 & $(6.01 \mathrm{E}-02)$ & $2.37 \mathrm{E}-02$ & $6.65 \mathrm{E}+00$ & $2.89 \mathrm{E}+01$ \\
\hline S06001-4 & C4606 & 45.71 & $(9.82 \mathrm{E}-02)$ & $4.61 \mathrm{E}-02$ & $5.80 \mathrm{E}+00$ & $1.87 \mathrm{E}+01$ \\
\hline S06001-5 & C4622 & 43.65 & $(1.27 \mathrm{E}-01)$ & $4.41 \mathrm{E}-02$ & $1.86 \mathrm{E}+01$ & $5.26 \mathrm{E}+01$ \\
\hline \multicolumn{7}{|c|}{$\begin{array}{l}\text { Bold values denote elevated concentrations. } \\
\text { Parentheses indicate reported value was less than the limit of quantification for the analysis. } \\
\text { NR indicates the information was not reported on the chain of custody. } \\
\text { Shaded cells indicate grab samples. }\end{array}$} \\
\hline
\end{tabular}

Table 4.10. Calculated Pore Water Mobile Metal Concentrations of Key Contaminants of Concern in the TY Tank Farm Direct Push Core and Grab Samples

\begin{tabular}{|c|c|c|c|c|c|c|}
\hline $\begin{array}{l}\text { Sample } \\
\text { ID }\end{array}$ & $\begin{array}{l}\text { Probe } \\
\text { Hole ID }\end{array}$ & $\begin{array}{l}\text { Mid-Depth } \\
\text { ft bgs }\end{array}$ & $\begin{array}{c}\text { Technetium-99 } \\
\text { pCi/L }\end{array}$ & $\begin{array}{c}\text { Uranium-238 } \\
\mu \mathrm{g} / \mathrm{L}\end{array}$ & $\begin{array}{l}\begin{array}{l}\text { Chromium } \\
\mu \mathrm{g} / \mathrm{L}\end{array} \\
\text { Com }\end{array}$ & $\begin{array}{c}\text { Molybdenum- } \\
95 \mu \mathrm{g} / \mathrm{L}\end{array}$ \\
\hline S06001-1A & C4604 & "44.95 & $\angle 3.33 \mathrm{E}+03$ & (5.56E-02) & $5.18 \mathrm{E}+03$ & $2.73 \mathrm{E}+03$ \\
\hline S06001-1 & C4604 & NR & $<3.46 \mathrm{E}+03$ & $1.32 \mathrm{E}+02$ & $(6.16 \mathrm{E}+01)$ & $1.80 \mathrm{E}+02$ \\
\hline S06001-2B & $\mathrm{C} 4624$ & 42.10 & $<3.00 \mathrm{E}+03$ & $5.78 \mathrm{E}+00$ & $(2.22 \mathrm{E}+02)$ & $2.07 \mathrm{E}+03$ \\
\hline S06001-2A & $\mathrm{C} 4624$ & 42.50 & $<2.05 \mathrm{E}+03$ & $1.22 \mathrm{E}+01$ & $(1.26 \mathrm{E}+02)$ & $3.36 \mathrm{E}+02$ \\
\hline S06001-2 & C4624 & 43.05 & $<3.24 \mathrm{E}+03$ & $1.81 \mathrm{E}+01$ & $(5.09 \mathrm{E}+01)$ & $3.07 \mathrm{E}+02$ \\
\hline S06001-3A & C4610 & 43.80 & $<3.08 \mathrm{E}+03$ & $1.21 \mathrm{E}+01$ & $(5.83 \mathrm{E}+01)$ & $3.03 \mathrm{E}+03$ \\
\hline S06001-3 & C4610 & 44.21 & $<2.74 \mathrm{E}+03$ & $1.27 \mathrm{E}+01$ & $(4.38 \mathrm{E}+01)$ & $2.21 \mathrm{E}+03$ \\
\hline S06001-4C & C4606 & 44.38 & $<3.98 \mathrm{E}+03$ & $3.40 \mathrm{E}+01$ & $(2.54 \mathrm{E}+01)$ & $1.90 \mathrm{E}+03$ \\
\hline S06001-4B & $\mathrm{C} 4606$ & 44.67 & $<2.88 \mathrm{E}+03$ & $2.19 \mathrm{E}+01$ & $(2.70 \mathrm{E}+01)$ & $2.79 \mathrm{E}+02$ \\
\hline S06001-4A & $\mathrm{C} 4606$ & 45.17 & $<2.63 \mathrm{E}+03$ & $3.12 \mathrm{E}+01$ & $(7.15 \mathrm{E}+01)$ & $2.48 \mathrm{E}+02$ \\
\hline S06001-4A DUP & $\mathrm{C} 4606$ & 45.17 & $<2.58 \mathrm{E}+03$ & $1.97 \mathrm{E}+01$ & $(3.33 \mathrm{E}+01)$ & $2.25 \mathrm{E}+02$ \\
\hline S06001-4 & C4606 & 45.71 & $<1.74 \mathrm{E}+03$ & $1.81 \mathrm{E}+01$ & $(5.62 \mathrm{E}+01)$ & $2.03 \mathrm{E}+02$ \\
\hline S06001-5 & C4622 & 43.65 & $<3.74 \mathrm{E}+03$ & $2.61 \mathrm{E}+01$ & $(1.56 \mathrm{E}+02)$ & $1.34 \mathrm{E}+03$ \\
\hline \multicolumn{7}{|c|}{$\begin{array}{l}\text { Bold values denote elevated concentrations. } \\
\text { Parentheses indicate reported value was less than the limit of quantification for the analysis. } \\
\text { Less than symbols indicate the instrument returned a negative value. } \\
\text { NR indicates the information was not contained on the chain of custody. } \\
\text { Shaded cells indicate grab samples. }\end{array}$} \\
\hline
\end{tabular}




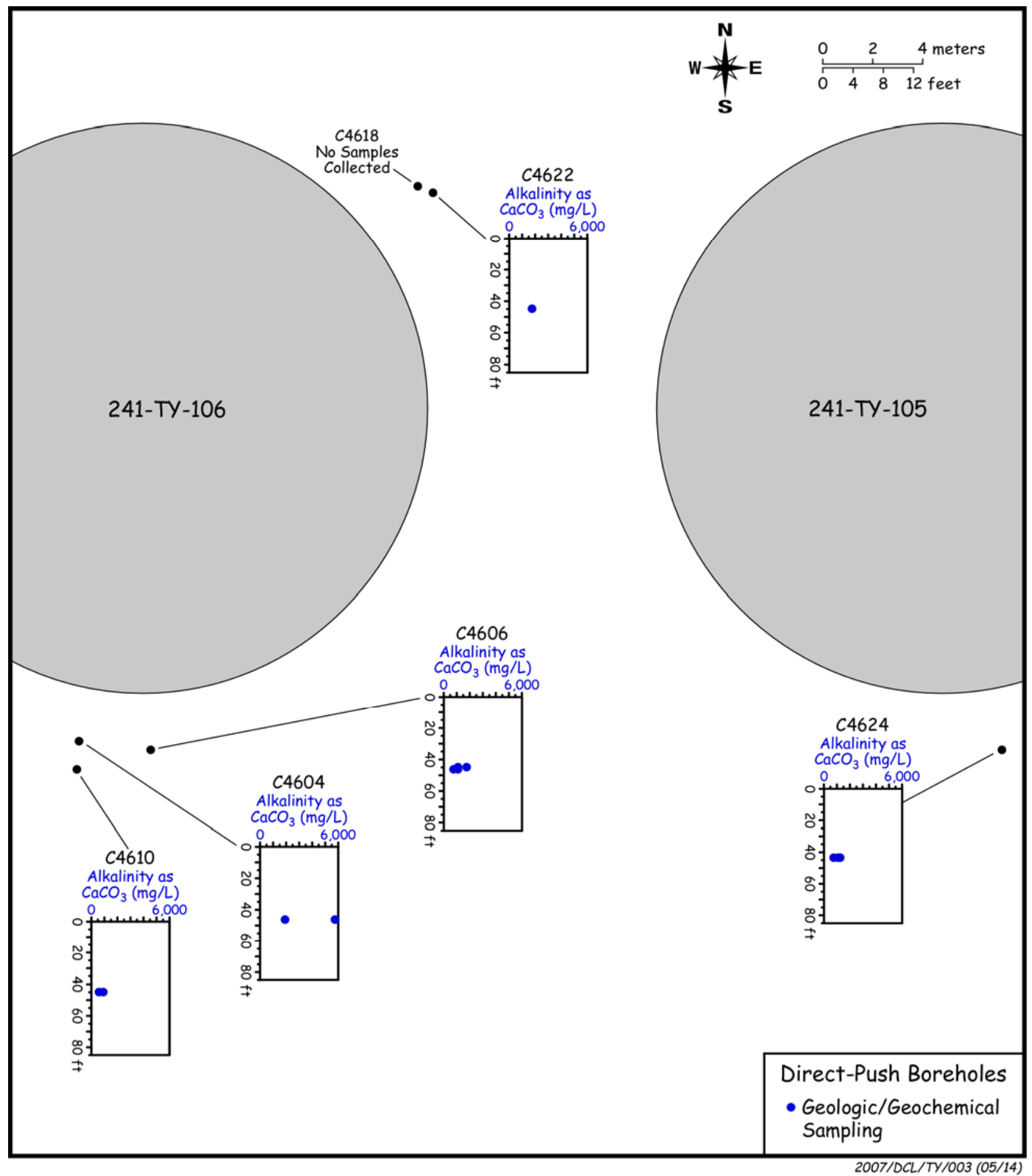

Figure 4.7. 1:1 Sediment:Water-Extractable Alkalinity Data from the TY Tank Farm Direct Push Samples 


\subsubsection{M Nitric Acid-Extractable Amounts of Selected Elements in the TY Tank Farm Direct Push Sediments}

The same cores and grab samples that were characterized for water-leachable constituents were also characterized to see how much of the various constituents could be extracted with hot $8 \mathrm{M}$ nitric acid. A comparison between the quantities that were acid extractable with those that are water-extractable often indicates the relative mobility of a given constituent and can sometimes differentiate man-disposed from naturally occurring constituents. The acid extractable concentrations are shown in Tables 4.11 through 4.13. For a majority of the constituents, there were no significantly elevated acid-extractable values in the TY Tank Farm direct push sediments, with the exception of chromium, molybdenum, and ruthenium.

Elevated acid-extractable chromium was found in the shoe material from direct push hole C4624. The chromium concentration in this sample was more than three times greater than that of the other direct push sediment samples. The same sample from the $\mathrm{C} 4624$ probe hole contained elevated molybdenum, which could be another indication of residual waste material in the sample. An alternate explanation is that the elevated chromium and molybdenum are from shavings lost from the sampler, which was composed of stainless steel, as it was being driven into the ground. Ruthenium was elevated in one of the direct push samples from probe hole C4606 and one sample from probe hole C4624.

Table 4.11. Acid-Extractable Cations in the TY Tank Farm Direct Push Core and Grab Samples $(\mu \mathrm{g} / \mathrm{g}$ dry sediment)

\begin{tabular}{||l|c|c|c|c|c||}
\hline $\begin{array}{c}\text { Sample } \\
\text { ID }\end{array}$ & $\begin{array}{c}\text { Probe Hole } \\
\text { ID }\end{array}$ & $\begin{array}{c}\text { Mid-Depth } \\
\mathrm{ft} \text { bgs }\end{array}$ & $\begin{array}{c}\text { Calcium } \\
\mu \mathrm{g} / \mathrm{g}\end{array}$ & $\begin{array}{c}\text { Potassium } \\
\mu \mathrm{g} / \mathrm{g}\end{array}$ & $\begin{array}{c}\text { Magnesium } \\
\mu \mathrm{g} / \mathrm{g}\end{array}$ \\
\hline \hline S06001-1A & C4604 & 44.95 & $\mathbf{1 . 6 7 E}+\mathbf{0 4}$ & $1.06 \mathrm{E}+03$ & $3.98 \mathrm{E}+03$ \\
\hline S06001-1 & C4604 & NR & $7.70 \mathrm{E}+03$ & $1.30 \mathrm{E}+03$ & $4.12 \mathrm{E}+03$ \\
\hline S06001-2B & C4624 & 42.10 & $7.95 \mathrm{E}+03$ & $1.01 \mathrm{E}+03$ & $4.01 \mathrm{E}+03$ \\
\hline S06001-2A & C4624 & 42.50 & $\mathbf{1 . 4 0 E}+\mathbf{0 4}$ & $8.76 \mathrm{E}+02$ & $4.34 \mathrm{E}+03$ \\
\hline S06001-2 & C4624 & 43.05 & $9.39 \mathrm{E}+03$ & $8.52 \mathrm{E}+02$ & $4.47 \mathrm{E}+03$ \\
\hline S06001-3A & C4610 & 43.80 & $6.53 \mathrm{E}+03$ & $8.48 \mathrm{E}+02$ & $3.30 \mathrm{E}+03$ \\
\hline S06001-3 & C4610 & 44.21 & $6.11 \mathrm{E}+03$ & $9.46 \mathrm{E}+02$ & $3.32 \mathrm{E}+03$ \\
\hline S06001-4C & C4606 & 44.38 & $6.73 \mathrm{E}+03$ & $(8.25 \mathrm{E}+02)$ & $3.32 \mathrm{E}+03$ \\
\hline S06001-4B & C4606 & 44.67 & $6.35 \mathrm{E}+03$ & $7.70 \mathrm{E}+02$ & $2.95 \mathrm{E}+03$ \\
\hline S06001-4A & C4606 & 45.17 & $6.48 \mathrm{E}+03$ & $9.91 \mathrm{E}+02$ & $3.76 \mathrm{E}+03$ \\
\hline S06001-4A DUP & C4606 & 45.17 & $7.58 \mathrm{E}+03$ & $1.09 \mathrm{E}+03$ & $4.00 \mathrm{E}+03$ \\
\hline S06001-4 & C4606 & 45.71 & $8.21 \mathrm{E}+03$ & $1.38 \mathrm{E}+03$ & $4.98 \mathrm{E}+03$ \\
\hline S06001-5 & C4622 & 43.65 & $(5.57 \mathrm{E}+02)$ & $2.40 \mathrm{E}+03$ \\
\hline $\begin{array}{l}\text { Bold values denote elevated concentrations. } \\
\text { Parentheses indicate the reported value is below the limit of quantification for the analysis. }\end{array}$ \\
$\begin{array}{l}\text { NR indicates the information was not contained on the chain of custody. } \\
\text { Shaded cells indicate grab samples. }\end{array}$ \\
\hline
\end{tabular}


Table 4.12. Acid-Leachable Cations in the TY Tank Farm Core and Grab Samples ( $\mu \mathrm{g} / \mathrm{g}$ dry sediment)

\begin{tabular}{|c|c|c|c|c|c|c|}
\hline $\begin{array}{l}\text { Sample } \\
\text { ID }\end{array}$ & $\begin{array}{l}\text { Probe Hole } \\
\text { ID }\end{array}$ & $\begin{array}{l}\text { Mid-Depth } \\
\text { ft bgs }\end{array}$ & $\begin{array}{l}\text { Aluminum } \\
\mu \mathrm{g} / \mathrm{g}\end{array}$ & $\begin{array}{l}\text { Iron } \\
\mu \mathrm{g} / \mathrm{g}\end{array}$ & $\begin{array}{c}\text { Phosphorus } \\
\mu \mathrm{g} / \mathrm{g}\end{array}$ & $\begin{array}{l}\text { Sulfur } \\
\mu \mathrm{g} / \mathrm{g}\end{array}$ \\
\hline S06001-1A & C4604 & 44.95 & $8.03 \mathrm{E}+03$ & $2.49 \mathrm{E}+04$ & $1.00 \mathrm{E}+03$ & $4.18 E+02$ \\
\hline S06001-1 & $\mathrm{C} 4604$ & NR & $7.25 \mathrm{E}+03$ & $2.31 \mathrm{E}+04$ & $1.11 \mathrm{E}+03$ & $(4.30 \mathrm{E}+01)$ \\
\hline S06001-2B & C4624 & 42.10 & $6.94 \mathrm{E}+03$ & $2.45 \mathrm{E}+04$ & $1.08 \mathrm{E}+03$ & $(6.67 \mathrm{E}+01)$ \\
\hline S06001-2A & $\mathrm{C} 4624$ & 42.50 & $7.76 \mathrm{E}+03$ & $2.51 \mathrm{E}+04$ & $1.06 \mathrm{E}+03$ & $2.21 \mathrm{E}+02$ \\
\hline S06001-2 & C4624 & 43.05 & $8.73 \mathrm{E}+03$ & $4.31 \mathrm{E}+04$ & $9.57 \mathrm{E}+02$ & $2.14 \mathrm{E}+02$ \\
\hline S06001-3A & $\mathrm{C} 4610$ & 43.80 & $4.68 \mathrm{E}+03$ & $1.50 \mathrm{E}+04$ & $8.99 \mathrm{E}+02$ & $(4.36 \mathrm{E}+01)$ \\
\hline S06001-3 & $\mathrm{C} 4610$ & 44.21 & $4.45 \mathrm{E}+03$ & $1.72 \mathrm{E}+04$ & $7.32 \mathrm{E}+02$ & $(3.54 \mathrm{E}+01)$ \\
\hline S06001-4C & $\mathrm{C} 4606$ & 44.38 & $6.13 \mathrm{E}+03$ & $2.08 \mathrm{E}+04$ & $8.86 \mathrm{E}+02$ & $(4.07 \mathrm{E}+01)$ \\
\hline S06001-4B & $\mathrm{C} 4606$ & 44.67 & $3.90 \mathrm{E}+03$ & $1.49 \mathrm{E}+04$ & $1.01 \mathrm{E}+03$ & $(3.99 \mathrm{E}+01)$ \\
\hline S06001-4A & $\mathrm{C} 4606$ & 45.17 & $6.11 \mathrm{E}+03$ & $1.94 \mathrm{E}+04$ & $9.14 \mathrm{E}+02$ & $(3.72 \mathrm{E}+01)$ \\
\hline S06001-4A DUP & $\mathrm{C} 4606$ & 45.17 & $6.80 \mathrm{E}+03$ & $2.16 \mathrm{E}+04$ & $1.03 \mathrm{E}+03$ & $(3.97 \mathrm{E}+01)$ \\
\hline S06001-4 & $\mathrm{C} 4606$ & 45.71 & $8.27 \mathrm{E}+03$ & $1.90 \mathrm{E}+04$ & $6.08 \mathrm{E}+02$ & $(3.30 \mathrm{E}+01)$ \\
\hline S06001-5 & C4622 & 43.65 & $3.24 \mathrm{E}+03$ & $1.20 \mathrm{E}+04$ & $8.80 \mathrm{E}+02$ & $(9.02 \mathrm{E}+01)$ \\
\hline \multicolumn{7}{|c|}{$\begin{array}{l}\text { Bold values denote elevated concentrations. } \\
\text { Parentheses indicated the reported value is below the limit of quantification for the analysis. } \\
\text { NR indicates the information was not contained on the chain of custody. } \\
\text { Shaded cells indicate grab samples. }\end{array}$} \\
\hline
\end{tabular}

Table 4.13. Acid-Extractable Mobile Metals in the TY Tank Farm Direct Push Core and Grab Samples ( $\mu \mathrm{g} / \mathrm{g}$ dry sediment)

\begin{tabular}{|c|c|c|c|c|c|c|c|}
\hline $\begin{array}{l}\text { Sample } \\
\text { ID }\end{array}$ & $\begin{array}{c}\text { Probe } \\
\text { Hole } \\
\text { ID }\end{array}$ & $\begin{array}{l}\text { Mid- } \\
\text { Depth } \\
\mathrm{ft} \text { bgs }\end{array}$ & $\begin{array}{c}\text { Technetium- } \\
99 \\
\text { pCi/g }\end{array}$ & $\begin{array}{c}\text { Uranium- } \\
238 \\
\mu \mathrm{g} / \mathrm{g}\end{array}$ & $\begin{array}{c}\text { Molybdenum- } \\
95 \\
\mu \mathrm{g} / \mathrm{g}\end{array}$ & $\begin{array}{c}\text { Ruthenium- } \\
101 \\
\mu \mathrm{g} / \mathrm{g}\end{array}$ & $\begin{array}{c}\text { Ruthenium- } \\
102 \\
\mu \mathrm{g} / \mathrm{g}\end{array}$ \\
\hline S06001-1A & C4604 & 44.95 & $<4.31 \mathrm{E}+01$ & $5.29 \mathrm{E}-01$ & $4.16 \mathrm{E}+00$ & $(2.50 \mathrm{E}-03)$ & $<<5.08 \mathrm{E}-03$ \\
\hline S06001-1 & C4604 & NR & $<5.53 \mathrm{E}+01$ & $8.04 \mathrm{E}-01$ & $5.57 \mathrm{E}-01$ & $2.55 \mathrm{E}-02$ & $<6.52 \mathrm{E}-03$ \\
\hline S06001-2B & C4624 & 42.10 & $<4.41 \mathrm{E}+01$ & $5.25 \mathrm{E}-01$ & $1.55 \mathrm{E}+00$ & $<5.20 \mathrm{E}-03$ & $<5.20 \mathrm{E}-03$ \\
\hline S06001-2A & C4624 & 42.50 & $(1.01 \mathrm{E}-01)$ & $6.00 \mathrm{E}-01$ & $2.39 \mathrm{E}+00$ & $<5.70 \mathrm{E}-03$ & $<5.70 \mathrm{E}-03$ \\
\hline S06001-2 & C4624 & 43.05 & $(1.50 \mathrm{E}+00)$ & $4.45 \mathrm{E}-01$ & $2.57 \mathrm{E}+01$ & 8.21E-05 & $<<5.31 \mathrm{E}-03$ \\
\hline S06001-3A & C4610 & 43.80 & $<5.07 \mathrm{E}+01$ & $4.34 \mathrm{E}-01$ & $1.86 \mathrm{E}+00$ & $<<5.98 \mathrm{E}-03$ & $<<5.98 \mathrm{E}-03$ \\
\hline S06001-3 & C4610 & 44.21 & $<5.13 \mathrm{E}+01$ & $3.81 \mathrm{E}-01$ & $6.83 \mathrm{E}+00$ & $<6.05 \mathrm{E}-03$ & $<6.05 \mathrm{E}-03$ \\
\hline S06001-4C & $\mathrm{C} 4606$ & 44.38 & $<5.60 \mathrm{E}+01$ & $4.47 \mathrm{E}-01$ & $1.32 \mathrm{E}+00$ & $<6.61 \mathrm{E}-03$ & $<6.61 \mathrm{E}-03$ \\
\hline S06001-4B & C4606 & 44.67 & $<4.85 \mathrm{E}+01$ & $4.10 \mathrm{E}-01$ & $4.28 \mathrm{E}-01$ & $<<5.72 \mathrm{E}-03$ & $<<5.72 \mathrm{E}-03$ \\
\hline S06001-4A & C4606 & 45.17 & $<4.61 \mathrm{E}+01$ & $5.45 \mathrm{E}-01$ & $3.84 \mathrm{E}-01$ & $<<5.44 \mathrm{E}-03$ & $<<5.44 \mathrm{E}-03$ \\
\hline S06001-4A DUP & C4606 & 45.17 & $<5.02 \mathrm{E}+01$ & $5.75 \mathrm{E}-01$ & $3.72 \mathrm{E}-01$ & $<<5.92 \mathrm{E}-03$ & $<<5.92 \mathrm{E}-03$ \\
\hline S06001-4 & C4606 & 45.71 & $<5.57 \mathrm{E}+01$ & $5.43 \mathrm{E}-01$ & $2.92 \mathrm{E}-01$ & $<6.57 \mathrm{E}-03$ & $<6.57 \mathrm{E}-03$ \\
\hline S06001-5 & $\mathrm{C} 4622$ & 43.65 & $<4.42 \mathrm{E}+01$ & $4.15 \mathrm{E}-01$ & $1.37 \mathrm{E}+00$ & $<5.22 \mathrm{E}-03$ & $<5.22 \mathrm{E}-03$ \\
\hline \multicolumn{8}{|c|}{$\begin{array}{l}\text { Bold values denote elevated concentrations. } \\
\text { Parentheses indicate reported value is less than the limit of quantification for the analysis. } \\
\text { Less than symbol indicates the instrument returned a negative value. } \\
\text { NR indicates the information was not contained on the chain of custody. } \\
\text { Less than symbols indicate the instrument returned a negative value. } \\
\text { Shaded cells indicate grab samples. }\end{array}$} \\
\hline
\end{tabular}


Comparison of the water to acid-extractable quantities of each constituent was performed by taking the data in Tables 4.3 through 4.6 and dividing them by the data in Tables 4.11 through 4.13 . The data are not presented herein, but show that less than $0.1 \%$ of the acid-extractable quantities of the following elements were water leachable: aluminum, barium, iron, lead, magnesium, manganese, phosphorous as phosphate, titanium, and zirconium. Less than $0.5 \%$ of the acid-extractable quantities of the following elements were water leachable: calcium, chromium, copper, nickel, and zinc. Less than $5 \%$ of the acidextractable potassium, strontium, and uranium were water-extractable. Finally, less than $30 \%$ of the acidextractable sulfur, as sulfate, was water-extractable.

\subsubsection{Radionuclide Content in Vadose Zone Sediment from the TY Tank Farm Direct Push Holes}

Data from the gamma energy analysis of the samples are shown in Table 4.14 and Figure 4.8. The direct measurement of sediment for gamma-emitting radionuclides showed that the sediments contained natural potassium-40 in all of the direct push probe holes except C4622, which is located northeast of tank 241-TY-106. The fission product isotope cesium-137 was found in both of the samples retrieved from probe hole $\mathrm{C} 4604$. The shoe material from probe hole $\mathrm{C} 4604$ contained $1.5 \mathrm{pCi} / \mathrm{g}$ cesium- 137 while the A-sleeve sample contained $0.6 \mathrm{pCi} / \mathrm{g}$ cesium-137. The A-sleeve sediment from probe hole $\mathrm{C} 4604$ was the only sample with an elevated soil $\mathrm{pH}$. Based on this, it seems likely that the slightly elevated $\mathrm{pH}$ in this sample coupled with the cesium-137 contamination is a result of contamination from a tank-related waste source. The most probable source of the contamination is the proposed leak from tank 241-TY-106.

Table 4.14. Gamma Emitting Radionuclides in the TY Tank Farm Direct Push Sediments

\begin{tabular}{|c|c|c|c|c|}
\hline $\begin{array}{l}\text { Sample } \\
\text { ID }\end{array}$ & $\begin{array}{l}\text { Probe Hole } \\
\text { ID }\end{array}$ & $\begin{array}{l}\text { Mid-Depth } \\
\mathrm{ft} \text { bgs }\end{array}$ & $\begin{array}{c}\text { Potassium- } 40 \\
\text { pCi } / \mathrm{g}\end{array}$ & $\begin{array}{c}\text { Cesium-137 } \\
\text { pCi/g }\end{array}$ \\
\hline S06001-1A & C4604 & 44.95 & $1.13 \mathrm{E}+01$ & "5.90E-01 \\
\hline S06001-1 & C4604 & NR & $9.72 \mathrm{E}+00$ & $1.53 E+00$ \\
\hline S06001-2B & $\mathrm{C} 4624$ & 42.10 & $<7.35 \mathrm{E}+00$ & $<4.22 \mathrm{E}-01$ \\
\hline S06001-2A & C4624 & 42.50 & $2.07 \mathrm{E}+00$ & $<4.11 \mathrm{E}-01$ \\
\hline S06001-2 & C4624 & 43.05 & $1.34 \mathrm{E}+01$ & $<2.45 \mathrm{E}-01$ \\
\hline S06001-3A & $\mathrm{C} 4610$ & 43.80 & $<7.64 \mathrm{E}+00$ & $<3.87 \mathrm{E}-01$ \\
\hline S06001-3 & $\mathrm{C} 4610$ & 44.21 & $1.69 \mathrm{E}+01$ & $<4.43 \mathrm{E}-01$ \\
\hline S06001-4C & $\mathrm{C} 4606$ & 44.38 & $8.85 \mathrm{E}+00$ & $<2.24 \mathrm{E}-01$ \\
\hline S06001-4B & $\mathrm{C} 4606$ & 44.67 & $<8.68 \mathrm{E}+00$ & $<2.16 \mathrm{E}-01$ \\
\hline S06001-4A & C4606 & 45.17 & $1.40 \mathrm{E}+01$ & $<4.05 \mathrm{E}-01$ \\
\hline S06001-4A DUP & $\mathrm{C} 4606$ & 45.17 & $1.33 \mathrm{E}+01$ & $<3.34 \mathrm{E}-01$ \\
\hline S06001-4 & $\mathrm{C} 4606$ & 45.71 & $<6.85 \mathrm{E}+00$ & $<2.23 \mathrm{E}-01$ \\
\hline S06001-5 & $\mathrm{C} 4622$ & 43.65 & $1.13 \mathrm{E}+01$ & $5.90 \mathrm{E}-01$ \\
\hline \multicolumn{5}{|c|}{$\begin{array}{l}\text { Bold values denote elevated concentrations. } \\
\text { ND indicates the analyte was not detected in the sample. } \\
\text { NR indicates the information was not contained on the chain of custody. } \\
\text { Shaded cells indicate grab samples. }\end{array}$} \\
\hline
\end{tabular}




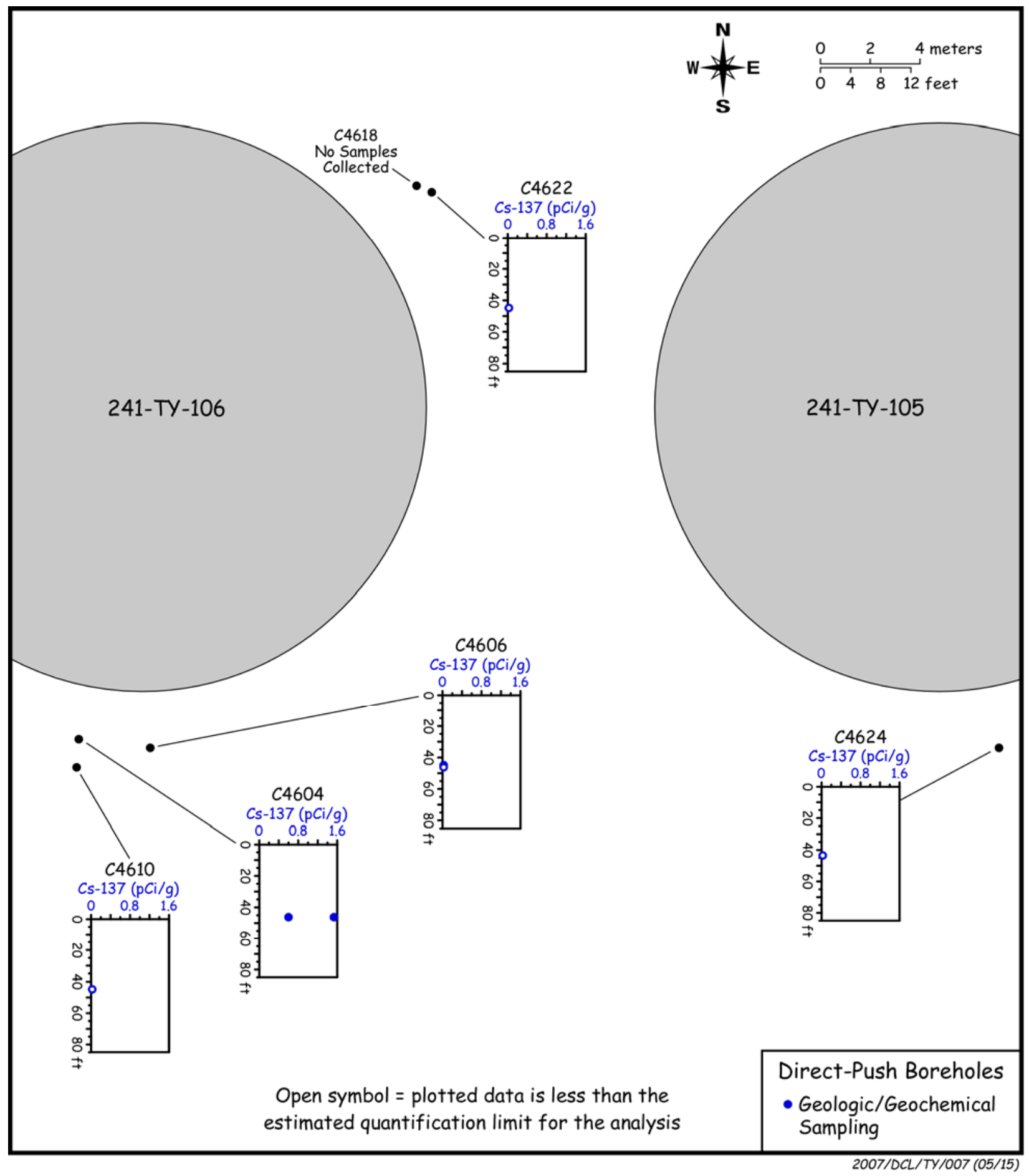

Figure 4.8. Gamma Energy Analysis Data (Cesium-137) from the TY Tank Farm Direct Push Samples 


\subsubsection{Total Carbon, Calcium Carbonate, and Organic Carbon Content of Vadose Zone Sediment from the TY Tank Farm Direct Push Holes}

Data from the total carbon, inorganic carbon, and organic carbon (calculated by difference) contents of the TY Tank Farm direct push sediments are shown in Table 4.15. The inorganic carbon was converted to the equivalent calcium carbonate content. In general, the sediments were low in organic carbon $(<0.15 \%$ by weight) which is typical of Hanford Site sediments. As a comparison, the average amount of organic carbon in sediments collected from the background borehole (299-W10-27) was 0.05\% by weight, while the average for all of the TY Tank Farm direct push samples was $0.07 \%$ by weight. Inorganic carbon, as $\mathrm{CaCO}_{3}$, was also present at concentrations that are typical for Hanford formation sediments ( 0.5 to $3.7 \mathrm{wt} \%$ as $\mathrm{CaCO}_{3}$ ) and compare well with other Hanford formation samples from uncontaminated locations (Serne et al. 2004a,b).

\subsection{Vadose Zone Sediment from the T Tank Farm Direct Push Samples}

\subsubsection{Moisture Content}

The moisture contents of the 23 core liners and 5 grab samples collected from the T direct push holes are presented as a function of depth in Table 4.16 and Figure 4.9. Several of the samples contained high soil moisture contents: the C-liner collected in probe hole C5378 at approximately $45 \mathrm{ft}$ bgs (11.7\%), all three liners collected from probe hole $\mathrm{C} 5374$ at depths ranging from approximately 80 to $81.5 \mathrm{ft}$ bgs (14.9-18.2\%), and the A- and B-liners collected from probe hole C5382 from a depth of approximately $79 \mathrm{ft}$ bgs (22.7\% and 14.9\%). The B and C liners from probe hole C5378 (collected at approximately $45 \mathrm{ft} \mathrm{bgs}$ ) contained sediment with appreciably different moisture contents (approximately a 50\% difference), indicating that the contact for the zone of increased moisture was encountered within the interval comprising the two liners $(1 \mathrm{ft})$. Photographs of the sediment removed from each liner, which are contained in Appendix $\mathrm{C}$ of this report, confirm the presence of finer-grained particles in the sediment contained within the $\mathrm{C}$ liner. The $\mathrm{B}$ and $\mathrm{C}$ liners from probe hole $\mathrm{C} 5382$ (collected at approximately $78 \mathrm{ft}$ bgs) also appeared to capture the contact between the Hanford formation and Cold Creek Unit. Photographs of the material taken from these two cores confirm the transition from a silt-dominated material to coarse-grained sand over the 12-inch span captured by the two liners.

The average gravimetric moisture content of all of the samples measured in this study was $7.9 \mathrm{wt} \%$, which was slightly higher than the average moisture content in core samples collected within the Hanford formation $\mathrm{H} 2$ unit (3.9\%) at the nearby TX Tank Farm characterization site (background borehole 299-W10-27 just east of the TY Tank Farm). However, the Cold Creek Unit was intercepted by several of the $\mathrm{T}$ direct samples, which caused the average moisture content for all of the samples to be biased high when compared to the coarse-grained materials comprising the Hanford formation H2 unit.

\subsubsection{1:1 Sediment:Water Extracts}

The samples from the T Tank Farm direct push were characterized by performing 1:1 sediment:water extracts. The following tables present the mass of a given constituent leached per gram of sediment as measured in the water extracts. Other tables show dilution-corrected values that represent concentrations in vadose zone pore water. As discussed in several other Vadose Zone Characterization Project reports, the dilution-corrected 1:1 sediment:water extracts are a reasonable estimate of the actual vadose zone pore water (see Serne et al. 2002a, 2002b, 2002c, 2002e, 2002f). 
Table 4.15. Carbon Content of the TY Tank Farm Vadose Zone Samples

\begin{tabular}{||l|c|c|c|c|c|c||}
\hline $\begin{array}{c}\text { Sample } \\
\text { ID }\end{array}$ & $\begin{array}{c}\text { Probe Hole } \\
\text { ID }\end{array}$ & $\begin{array}{c}\text { Mid-Depth } \\
\text { ft bgs }\end{array}$ & $\begin{array}{c}\text { Total Carbon } \\
(\%)\end{array}$ & $\begin{array}{c}\text { Inorganic } \\
\text { Carbon } \\
(\%)\end{array}$ & $\begin{array}{c}\text { Inorganic Carbon } \\
\text { as CaCO3 } \\
(\%)\end{array}$ & $\begin{array}{c}\text { Organic } \\
\text { Carbon } \\
(\%)\end{array}$ \\
\hline \hline S06001-1A & C4604 & 44.95 & $3.54 \mathrm{E}-01$ & $2.47 \mathrm{E}-01$ & $2.06 \mathrm{E}+00$ & $1.08 \mathrm{E}-01$ \\
\hline S06001-1 & $\mathrm{C} 4604$ & NR & $1.63 \mathrm{E}-01$ & $1.12 \mathrm{E}-01$ & $9.33 \mathrm{E}-01$ & $5.10 \mathrm{E}-02$ \\
\hline S06001-2B & $\mathrm{C} 4624$ & 42.10 & $2.04 \mathrm{E}-01$ & $1.14 \mathrm{E}-01$ & $9.53 \mathrm{E}-01$ & $8.96 \mathrm{E}-02$ \\
\hline S06001-2A & $\mathrm{C} 4624$ & 42.50 & $5.75 \mathrm{E}-01$ & $4.38 \mathrm{E}-01$ & $3.65 \mathrm{E}+00$ & $1.37 \mathrm{E}-01$ \\
\hline S06001-2 & $\mathrm{C} 4624$ & 43.05 & $1.78 \mathrm{E}-01$ & $1.05 \mathrm{E}-01$ & $8.73 \mathrm{E}-01$ & $7.36 \mathrm{E}-02$ \\
\hline S06001-3A & $\mathrm{C} 4610$ & 43.80 & $1.76 \mathrm{E}-01$ & $9.38 \mathrm{E}-02$ & $7.82 \mathrm{E}-01$ & $8.18 \mathrm{E}-02$ \\
\hline S06001-3 & $\mathrm{C} 4610$ & 44.21 & $2.08 \mathrm{E}-01$ & $1.58 \mathrm{E}-01$ & $1.32 \mathrm{E}+00$ & $5.05 \mathrm{E}-02$ \\
\hline S06001-4C & $\mathrm{C} 4606$ & 44.38 & $1.20 \mathrm{E}-01$ & $5.52 \mathrm{E}-02$ & $4.60 \mathrm{E}-01$ & $6.52 \mathrm{E}-02$ \\
\hline S06001-4B & $\mathrm{C} 4606$ & 44.67 & $1.93 \mathrm{E}-01$ & $1.42 \mathrm{E}-01$ & $1.19 \mathrm{E}+00$ & $5.07 \mathrm{E}-02$ \\
\hline S06001-4A & C4606 & 45.17 & $2.24 \mathrm{E}-01$ & $1.71 \mathrm{E}-01$ & $1.43 \mathrm{E}+00$ & $5.30 \mathrm{E}-02$ \\
\hline S06001-4A DUP & C4606 & 45.17 & $2.40 \mathrm{E}-01$ & $1.80 \mathrm{E}-01$ & $1.50 \mathrm{E}+00$ & $5.99 \mathrm{E}-02$ \\
\hline S06001-4 & $\mathrm{C} 4606$ & 45.71 & $2.78 \mathrm{E}-01$ & $1.92 \mathrm{E}-01$ & $1.60 \mathrm{E}+00$ & $8.62 \mathrm{E}-02$ \\
\hline S06001-5 & C4622 & 43.65 & $3.44 \mathrm{E}-01$ & $2.92 \mathrm{E}-01$ & $2.44 \mathrm{E}+00$ & $5.13 \mathrm{E}-02$ \\
\hline $\begin{array}{l}\text { NR indicates the information was not contained on the chain of custody. } \\
\text { Shaded cells indicate grab samples. }\end{array}$ \\
\hline
\end{tabular}

Table 4.16. Gravimetric Moisture Content of Samples Obtained from the T Tank Farm Direct Push Probe Holes

\begin{tabular}{||l|c|c|c||}
\hline \multicolumn{1}{|c|}{$\begin{array}{c}\text { Sample } \\
\text { ID }\end{array}$} & $\begin{array}{c}\text { Probe Hole } \\
\text { ID }\end{array}$ & $\begin{array}{c}\text { Mid-Depth } \\
\mathrm{ft} \text { bgs }\end{array}$ & $\begin{array}{c}\text { Moisture } \\
(\%)\end{array}$ \\
\hline \hline B1KC35A & C4598 & 43.8 & $3.97 \%$ \\
\hline B1KC35B & C4598 & 43.3 & $4.30 \%$ \\
\hline B1KC36 & C4596 & 48.9 & $3.50 \%$ \\
\hline B1KC36A & C4596 & 48.3 & $6.37 \%$ \\
\hline B1KC36B & C4596 & 47.8 & $4.21 \%$ \\
\hline B1KC36C & C4596 & 47.3 & $4.57 \%$ \\
\hline B1KC37A & C5378 & 46.3 & $2.58 \%$ \\
\hline B1KC37B & C5378 & 45.8 & $5.87 \%$ \\
\hline B1KC37C & C5378 & 45.3 & $11.7 \%$ \\
\hline B1KC38 & C5378 & 63.8 & $4.40 \%$ \\
\hline B1KC38A & C5378 & 63.3 & $5.18 \%$ \\
\hline B1KC38B & C5378 & 62.8 & $5.48 \%$ \\
\hline B1KC38C & C5378 & 62.3 & $6.51 \%$ \\
\hline B1KC39 & C5384 & 45.8 & $4.66 \%$ \\
\hline B1KC39A & C5384 & 45.3 & $3.56 \%$ \\
\hline B1KC39B & C5384 & 44.8 & $4.54 \%$ \\
\hline B1KC39C & C5384 & 44.3 & $6.10 \%$ \\
\hline B1KC40 & C5374 & 81.8 & $8.35 \%$ \\
\hline B1KC40A & C5374 & 81.3 & $16.6 \%$ \\
\hline B1KC40B & C5374 & 80.8 & $18.2 \%$ \\
\hline B1KC40C & C5374 & 80.3 & $14.9 \%$ \\
\hline B1LB07A & C5382 & 79.3 & $22.7 \%$ \\
\hline B1LB07B & C5382 & 78.8 & $14.9 \%$ \\
\hline B1LB07C & C5382 & 78.3 & $5.98 \%$ \\
\hline B1LB08 & C5380 & 51.8 & $5.65 \%$ \\
\hline B1LB08A & C5380 & 51.3 & $8.33 \%$ \\
\hline B1LB08B & C5380 & 50.8 & $9.14 \%$ \\
\hline B1LB08C & C5380 & 50.3 & $8.27 \%$ \\
\hline Shaded cells indicate grab samples. & & \\
\hline
\end{tabular}




\subsubsection{1 $\quad \mathrm{pH}$ and Electrical Conductivity}

The 1:1 sediment:water extract $\mathrm{pH}$ and $\mathrm{EC}$ data for the $\mathrm{T}$ Tank Farm core and grab samples are shown in Table 4.17 and Figure 4.10. The $\mathrm{pH}$ is tabulated as measured in the 1:1 sediment:water extracts but the EC is corrected for dilution and tabulated as if it was actual pore water. Several of the 1:1 sediment:water extracts were elevated in $\mathrm{pH}$ (greater than 8.5). The sediments characterized as having an elevated $\mathrm{pH}(>8.5)$ were collected from probe holes C4598, C4596, and C5378 at depths ranging from approximately 43 to $63 \mathrm{ft}$ bgs. Previous borehole reports have shown that regions of elevated soil $\mathrm{pH}$ are considered to be good indicators of the location of the original leak event or very near-field close to the initial tank waste entry zone (see Serne et al. 2002a, 2002b, 2002c, 2002e, 2002f). Therefore, we can conclude that the elevated $\mathrm{pH}$ data indicates the presence of caustic tank-related waste from tank 241-T-101.

The pore water-corrected EC data for many of the samples were low, with a range of 1.26 to $6.58 \mathrm{mS} / \mathrm{cm}$. However, all of the samples that exhibited elevated sediment $\mathrm{pH}$ 's also had elevated porewater conductivities because of more abundant water-dissolvable salts remaining on the sediment after tank-waste contact. For example, the core samples taken from probe hole C4598 had the highest porewater-corrected conductivities (at 19.2 and $21.1 \mathrm{mS} / \mathrm{cm}$ ) measured as part of the T Tank Farm direct push study. Not surprisingly, probe hole C4598 was the closest sampling hole in proximity to tank

Table 4.17. $\quad \mathrm{pH}$ for 1:1 Sediment:Water Extracts and Dilution-Corrected EC Values from T Tank Farm Core and Grab Samples

\begin{tabular}{||l|c|c|c|c||}
\hline $\begin{array}{c}\text { Sample } \\
\text { ID }\end{array}$ & $\begin{array}{c}\text { Probe Hole } \\
\text { ID }\end{array}$ & $\begin{array}{c}\text { Mid-Depth } \\
\mathrm{ft} \text { bgs }\end{array}$ & $\mathrm{pH}$ & $\begin{array}{c}\text { Conductivity } \\
(\mathrm{mS} / \mathrm{cm})\end{array}$ \\
\hline \hline B1KC35A & C4598 & 43.8 & $\mathbf{9 . 5 1}$ & $\mathbf{2 1 . 1}$ \\
\hline B1KC35B & C4598 & 43.3 & $\mathbf{9 . 4 6}$ & $\mathbf{1 9 . 2}$ \\
\hline B1KC36A & C4596 & 48.3 & $\mathbf{9 . 0 7}$ & $\mathbf{1 2 . 2}$ \\
\hline B1KC36B & C4596 & 47.8 & $\mathbf{9 . 1 6}$ & $\mathbf{1 6 . 1}$ \\
\hline B1KC36C & C4596 & 47.3 & $\mathbf{8 . 7 7}$ & $\mathbf{1 3 . 9}$ \\
\hline B1KC37A & C5378 & 46.3 & 8.23 & $\mathbf{1 2 . 4}$ \\
\hline B1KC37B & C5378 & 45.8 & 8.28 & 6.22 \\
\hline B1KC37C & C5378 & 45.3 & 7.83 & 2.09 \\
\hline B1KC38A & C5378 & 63.3 & $\mathbf{9 . 6 4}$ & $\mathbf{1 6 . 8}$ \\
\hline B1KC38B & C5378 & 62.8 & $\mathbf{9 . 2 9}$ & $\mathbf{1 6 . 3}$ \\
\hline B1KC38C & C5378 & 62.3 & $\mathbf{9 . 1 3}$ & $\mathbf{1 6 . 9}$ \\
\hline B1KC39A & C5384 & 45.3 & 7.82 & 5.45 \\
\hline B1KC39B & C5384 & 44.8 & 7.82 & 4.63 \\
\hline B1KC39C & C5384 & 44.3 & 7.94 & 3.93 \\
\hline B1KC40A & C5374 & 81.3 & 7.65 & 6.01 \\
\hline B1KC40B & C5374 & 80.8 & 7.55 & 4.22 \\
\hline B1KC40C & C5374 & 80.3 & 7.49 & 6.58 \\
\hline B1LB07A & C5382 & 79.3 & 7.95 & 1.26 \\
\hline B1LB07B & C5382 & 78.8 & 7.92 & 1.71 \\
\hline B1LB07C & C5382 & 78.3 & 7.64 & 3.70 \\
\hline B1LB08A & C5380 & 51.3 & 8.10 & 3.76 \\
\hline B1LB08B & C5380 & 50.8 & 8.09 & 3.53 \\
\hline B1LB08C & C5380 & 50.3 & 8.26 & 3.69 \\
\hline Bold values denote elevated concentrations. \\
EC values are dilution corrected and represent pore water concentrations not 1:1 extract values. \\
\hline
\end{tabular}




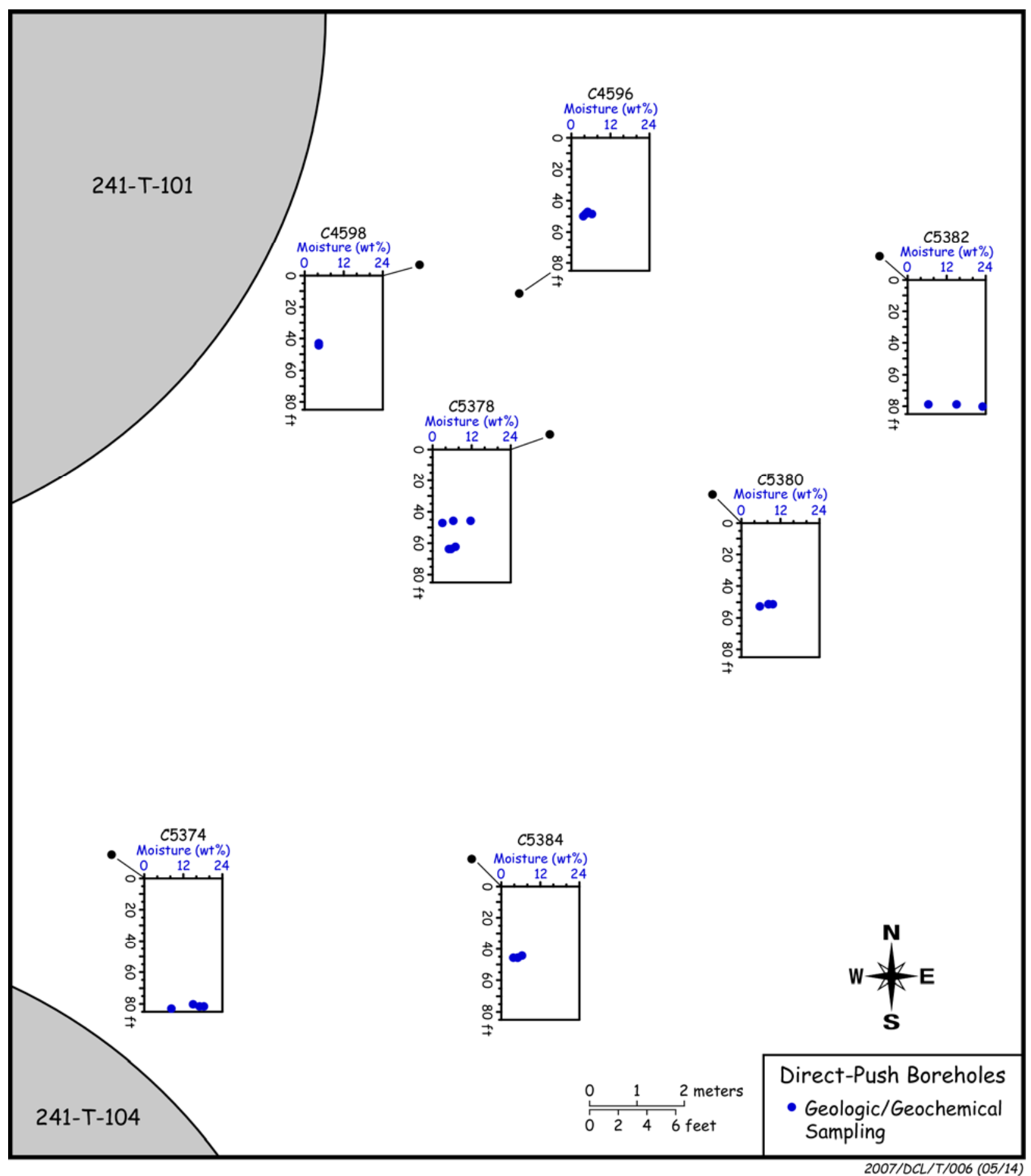

Figure 4.9. Moisture Content Data for the T Tank Farm Direct Push Samples

241-T-101. The next highest conductivity was found in samples from probe hole C5378, which was located approximately $5 \mathrm{~m}$ to the southeast of tank 241-T-101. These samples were collected at a depth of approximately $63 \mathrm{ft}$ bgs, which was $20 \mathrm{ft}$ deeper than the depth of the $\mathrm{C} 4598$ samples. These results indicate that the initial impact zone from waste released from tank 241-T-101 migrated to the southeast of the tank to at least the location and depth intercepted by probe hole C5378. 


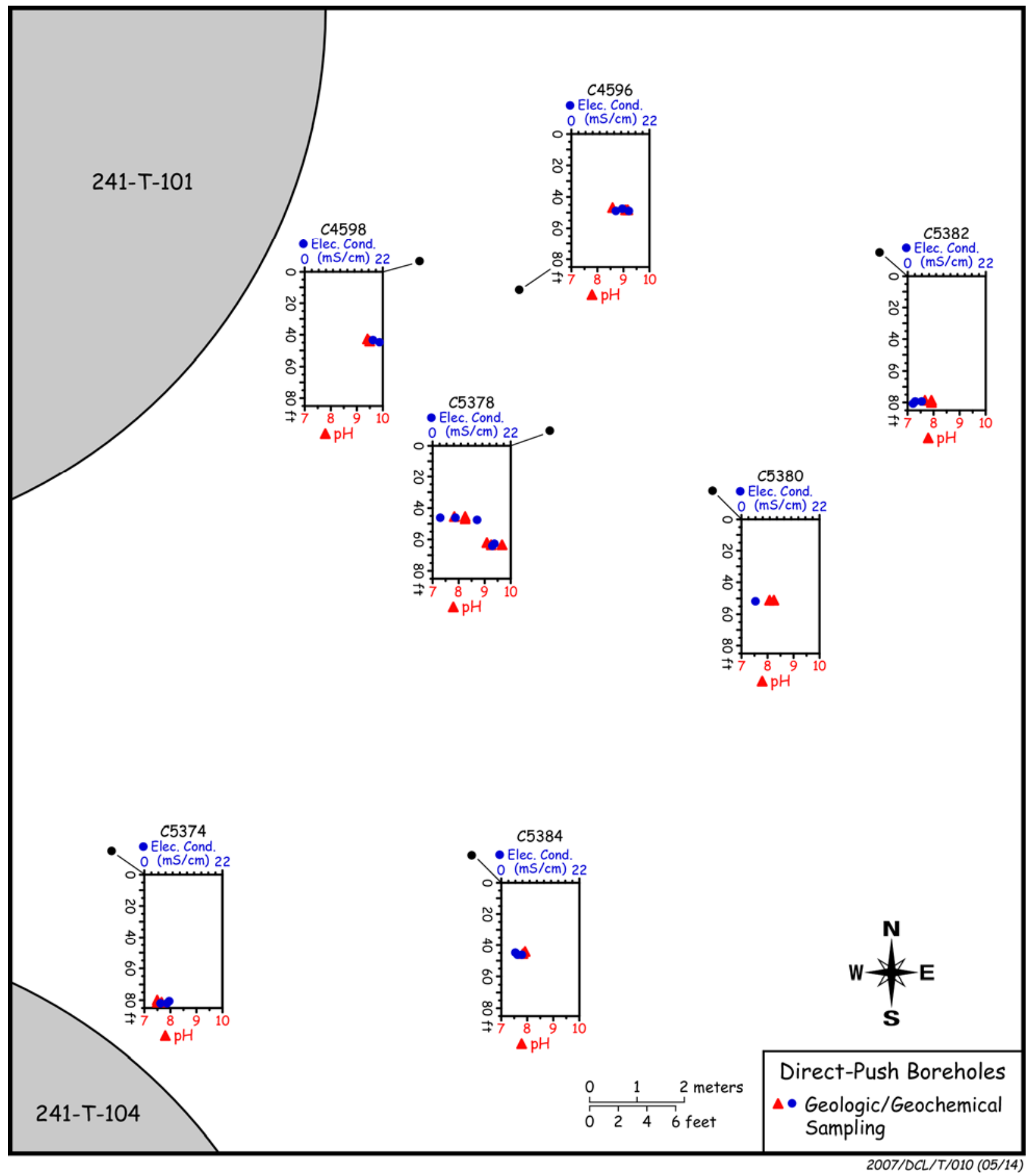

Figure 4.10. $\mathrm{pH}$ for 1:1 Sediment:Water Extracts and Dilution-Corrected EC Values from $\mathrm{T}$ Tank Farm 


\subsubsection{Composition of the 1:1 Sediment:Water Extracts from the T Tank Farm Core and Grab Samples}

The water extract values for the major anions, cations, and several trace constituents are discussed in this section. The anion data are tabulated in Table 4.18 and Figures 4.11 and 4.12 in units of mass per gram of dry sediment. Several of the 1:1 sediment:water extracts contained slightly elevated concentrations of fluoride (greater than $1 \mu \mathrm{g} / \mathrm{g}$ ). Unfortunately, there was an unidentified chromatographic interference that precluded the quantification of fluoride in most of the direct push samples. The average 1:1 sediment:water extract fluoride value for the $\mathrm{T}$ Tank Farm probe holes that could be resolved $(1.34 \mu \mathrm{g} / \mathrm{g})$ was approximately a factor of two higher than the average fluoride concentration $(0.60 \mu \mathrm{g} / \mathrm{g})$ measured in the background borehole 299-W10-27. Elevated water-extractable chloride was found in one core sample from probe hole C5382. Probe hole C5382 was emplaced the furthest eastward with respect to tank 241-T-101. Additionally, the sample was collected at approximately $78 \mathrm{ft}$ bgs. The combination of its location relative to the tank and its depth in the vadose zone can potentially provide insight on the migration pathway of mobile contaminants. Water-extractable nitrate was significantly elevated (in excess of $250 \mu \mathrm{g} / \mathrm{g}$ ) in the string of cores collected from probe hole C5374 from approximately $80 \mathrm{ft}$ bgs within the fine-grained Upper Cold Creek Unit. Probe hole C5374 was emplaced to the south of tank 241-T-101 and adjacent to tank 241-T-104. It is obvious that tank waste has impacted the vadose zone at this location; however, this single set of data does not permit the source of the contamination to be identified. The same samples that contained significantly elevated water-extractable nitrate also contained elevated sulfate $(93.9$ to $117 \mu \mathrm{g} / \mathrm{g})$. It is possible that the elevated sulfate in these samples is natural sulfate present in the sediments that has been displaced by the nitrate plume in the area. The majority of the samples did not contain quantifiable amounts of water-extractable phosphate; however, a few of the samples collected shallower in the vadose zone contained water-extractable phosphate in excess of $1 \mu \mathrm{g} / \mathrm{g}$. Interestingly, none of the waste streams purported to have been part of the composition of the leak from tank T-101 contained phosphate (Serne et al. 2007)

The water-extractable major cations in the T Tank Farm probe hole sediments are tabulated in Table 4.19 and Figure 4.13 in units of mass per gram of sediment on a dry weight basis. All three cores from probe hole $\mathrm{C} 5374$ contained elevated concentrations of calcium, potassium, magnesium, strontium, and sodium. Although the sediments from this probe hole contained elevated concentrations of water-extractable sodium, they were the only samples analyzed that had calcium as the dominant water-extractable cation. It was surprising to find elevated calcium, magnesium, and sodium together in the same sample, since the sodium would typically drive the divalent cations off the exchange sites; this phenomenon could indicate that the samples were collected near the leading edge of the ion exchange front. However, it is impossible to confirm this hypothesis given the lack of sample coverage (particularly with respect to depth) in the area. All of the remaining core samples analyzed contained sodium as the dominant water-extractable cation, including those collected from probe hole C5382. Probe hole C5382 was emplaced to the same approximate depth as probe hole C5374, but was located much further to the northeast. If the tank waste residuals found in these two probe holes are a result of the same leak event, it appears that the ion exchange front resides deeper in the vadose zone to the east of tank 241-T-101 than it does to the southeast. However, given the overall lack of sample coverage, it is not possible to determine if the two probe holes have intercepted the same leak event. Either way, based on the water-extractable concentrations of sodium, calcium, and magnesium, there are signs of cation exchange in all of the probe holes emplaced around tanks 241-T-101 and 241-T-104. 
Table 4.18. Water-Extractable Anions in the T Tank Farm Core and Grab Samples ( $\mu \mathrm{g} / \mathrm{g}$ dry sediment)

\begin{tabular}{|c|c|c|c|c|c|c|c|}
\hline $\begin{array}{l}\text { Sample } \\
\text { ID }\end{array}$ & $\begin{array}{c}\text { Probe Hole } \\
\text { ID }\end{array}$ & $\begin{array}{c}\text { Mid-Depth } \\
\text { ft bgs }\end{array}$ & $\begin{array}{c}\text { Fluoride } \\
\mu \mathrm{g} / \mathrm{g}\end{array}$ & $\begin{array}{c}\text { Chloride } \\
\mu \mathrm{g} / \mathrm{g}\end{array}$ & $\begin{array}{c}\text { Nitrate } \\
\mu \mathrm{g} / \mathrm{g}\end{array}$ & $\begin{array}{c}\text { Sulfate } \\
\mu \mathrm{g} / \mathrm{g}\end{array}$ & $\begin{array}{c}\text { Phosphate } \\
\mu \mathrm{g} / \mathrm{g}\end{array}$ \\
\hline B1KC35A & C4598 & 43.8 & $\mathrm{ND}$ & $<5.02 \mathrm{E}-01$ & $4.49 \mathrm{E}+00$ & $5.81 \mathrm{E}+00$ & $2.08 E+00$ \\
\hline B1KC35B & C4598 & 43.3 & $\mathrm{ND}$ & $2.30 \mathrm{E}+00$ & $5.90 \mathrm{E}+00$ & $1.24 \mathrm{E}+01$ & $\mathrm{ND}$ \\
\hline B1KC36A & C4596 & 48.3 & ND & $<5.05 \mathrm{E}-01$ & $4.52 \mathrm{E}+00$ & $1.11 \mathrm{E}+01$ & $2.64 \mathrm{E}+00$ \\
\hline B1KC36B & C4596 & 47.8 & $\mathrm{ND}$ & $<5.18 \mathrm{E}-01$ & $2.11 \mathrm{E}+00$ & $8.05 \mathrm{E}+00$ & $<1.56 \mathrm{E}+00$ \\
\hline B1KC36C & C4596 & 47.3 & ND & $<5.33 \mathrm{E}-01$ & $2.06 \mathrm{E}+00$ & $8.10 \mathrm{E}+00$ & $1.64 \mathrm{E}+00$ \\
\hline B1KC37A & C5378 & 46.3 & ND & $<5.19 \mathrm{E}-01$ & $1.21 \mathrm{E}+00$ & $7.00 \mathrm{E}+00$ & $<1.56 \mathrm{E}+00$ \\
\hline $\mathrm{B} 1 \mathrm{KC} 37 \mathrm{~B}$ & $\mathrm{C} 5378$ & 45.8 & $1.41 E+00$ & $<5.00 \mathrm{E}-01$ & $2.02 \mathrm{E}+00$ & $8.12 \mathrm{E}+00$ & $<1.50 \mathrm{E}+00$ \\
\hline B1KC37C & C5378 & 45.3 & $1.34 \mathrm{E}+00$ & $1.54 \mathrm{E}+00$ & $3.59 \mathrm{E}+00$ & $1.59 \mathrm{E}+01$ & ND \\
\hline B1KC38A & $\mathrm{C} 5378$ & 63.3 & ND & $<5.16 \mathrm{E}-01$ & $8.33 E+00$ & $5.78 \mathrm{E}+00$ & $<1.55 \mathrm{E}+00$ \\
\hline B1KC38B & C5378 & 62.8 & ND & $<5.06 \mathrm{E}-01$ & $6.47 E+00$ & $6.93 \mathrm{E}+00$ & $1.50 \mathrm{E}+00$ \\
\hline B1KC38C & C5378 & 62.3 & $3.31 E+00$ & $<5.14 \mathrm{E}-01$ & $4.45 \mathrm{E}+00$ & $1.30 \mathrm{E}+01$ & $1.94 \mathrm{E}+00$ \\
\hline B1KC39A & C5384 & 45.3 & 4.94E-01 & $<5.05 \mathrm{E}-01$ & $2.06 \mathrm{E}+00$ & $8.02 \mathrm{E}+00$ & $2.58 \mathrm{E}+00$ \\
\hline B1KC39B & C5384 & 44.8 & $6.47 \mathrm{E}-01$ & $<5.10 \mathrm{E}-01$ & $2.74 \mathrm{E}+00$ & $7.73 \mathrm{E}+00$ & $<1.52 \mathrm{E}+00$ \\
\hline B1KC39C & C5384 & 44.3 & $1.10 \mathrm{E}+00$ & $9.24 \mathrm{E}-01$ & $1.83 \mathrm{E}+00$ & $1.46 \mathrm{E}+01$ & $<1.53 \mathrm{E}+00$ \\
\hline $\mathrm{B} 1 \mathrm{KC} 40 \mathrm{~A}$ & C5374 & 81.3 & $\mathrm{ND}$ & $1.69 \mathrm{E}+01$ & $2.94 E+02$ & $1.17 \mathrm{E}+02$ & ND \\
\hline $\mathrm{B} 1 \mathrm{KC} 40 \mathrm{~B}$ & C5374 & 80.8 & ND & $1.52 \mathrm{E}+01$ & $2.65 E+02$ & $1.04 \mathrm{E}+02$ & $<1.52 \mathrm{E}+00$ \\
\hline $\mathrm{B} 1 \mathrm{KC} 40 \mathrm{C}$ & $\mathrm{C} 5374$ & 80.3 & $\mathrm{ND}$ & $1.79 \mathrm{E}+01$ & $3.31 E+02$ & $9.39 \mathrm{E}+01$ & $<1.52 \mathrm{E}+00$ \\
\hline B1LB07A & C5382 & 79.3 & ND & $2.12 \mathrm{E}+00$ & $1.12 \mathrm{E}+01$ & $2.50 \mathrm{E}+01$ & $<1.51 \mathrm{E}+00$ \\
\hline B1LB07B & C5382 & 78.8 & ND & $2.54 \mathrm{E}+00$ & $6.70 \mathrm{E}+00$ & $1.64 \mathrm{E}+01$ & $<1.51 \mathrm{E}+00$ \\
\hline B1LB07C & C5382 & 78.3 & ND & $5.60 \mathrm{E}+00$ & $1.65 \mathrm{E}+00$ & $1.21 \mathrm{E}+01$ & $<1.51 \mathrm{E}+00$ \\
\hline B1LB08A & C5380 & 51.3 & $\mathrm{ND}$ & $6.48 \mathrm{E}-01$ & $<1.03 \mathrm{E}+00$ & $9.50 \mathrm{E}+00$ & ND \\
\hline B1LB08B & C5380 & 50.8 & ND & 7.94E-01 & $1.66 \mathrm{E}+00$ & $6.49 \mathrm{E}+00$ & ND \\
\hline B1LB08C & C5380 & 50.3 & $1.08 \mathrm{E}+00$ & $9.60 \mathrm{E}-01$ & $<1.02 \mathrm{E}+00$ & $5.58 \mathrm{E}+00$ & $<1.51 \mathrm{E}+00$ \\
\hline
\end{tabular}

The water-extractable aluminum, iron, silicon, and sulfur in the T Tank Farm direct push sediments are shown in Table 4.20. The sulfur data were converted to water-extractable sulfur as sulfate so that the results could be compared to the IC data presented in Table 4.18. The agreement between measuring the water extracts for sulfate directly with the ion chromatograph and indirectly by converting the ICP measurements for sulfur to sulfate was very good. Besides validating the ion chromatography data, we can state that the water-extractable sulfur was in fact sulfate. Water-soluble aluminum was elevated (above the limit of detection) in sediment from all of the probe holes except that from probe hole C5374. It appears that these elevated values are a result of some chemical reaction, such as dissolution or precipitation, between alkaline tank fluids and native sediments that formed precipitates of amorphous aluminum phases that are more water soluble than aluminum-rich crystalline mineral phases in the native sediments.

The water extract data for potentially mobile metals, such as technetium-99, uranium-238, chromium, molybdenum and ruthenium are shown in Table 4.21. Additionally, the water-extractable technetium-99 and uranium-238 are plotted as a function of depth in Figures 4.14 and 4.15. Water-extractable 


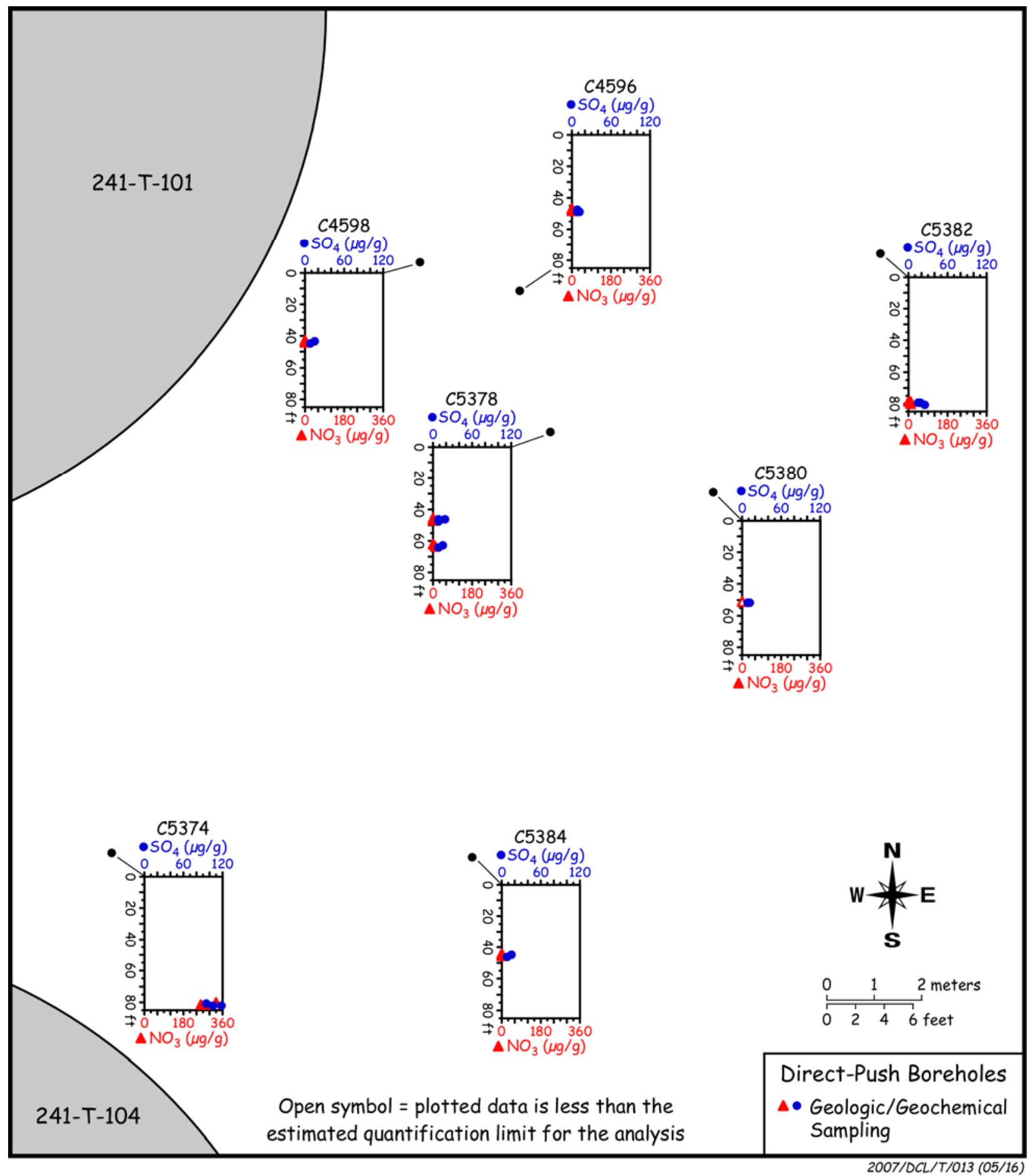

Figure 4.11. 1:1 Sediment:Water-Extractable Nitrate and Sulfate data from the T Tank Farm Direct Push Samples 


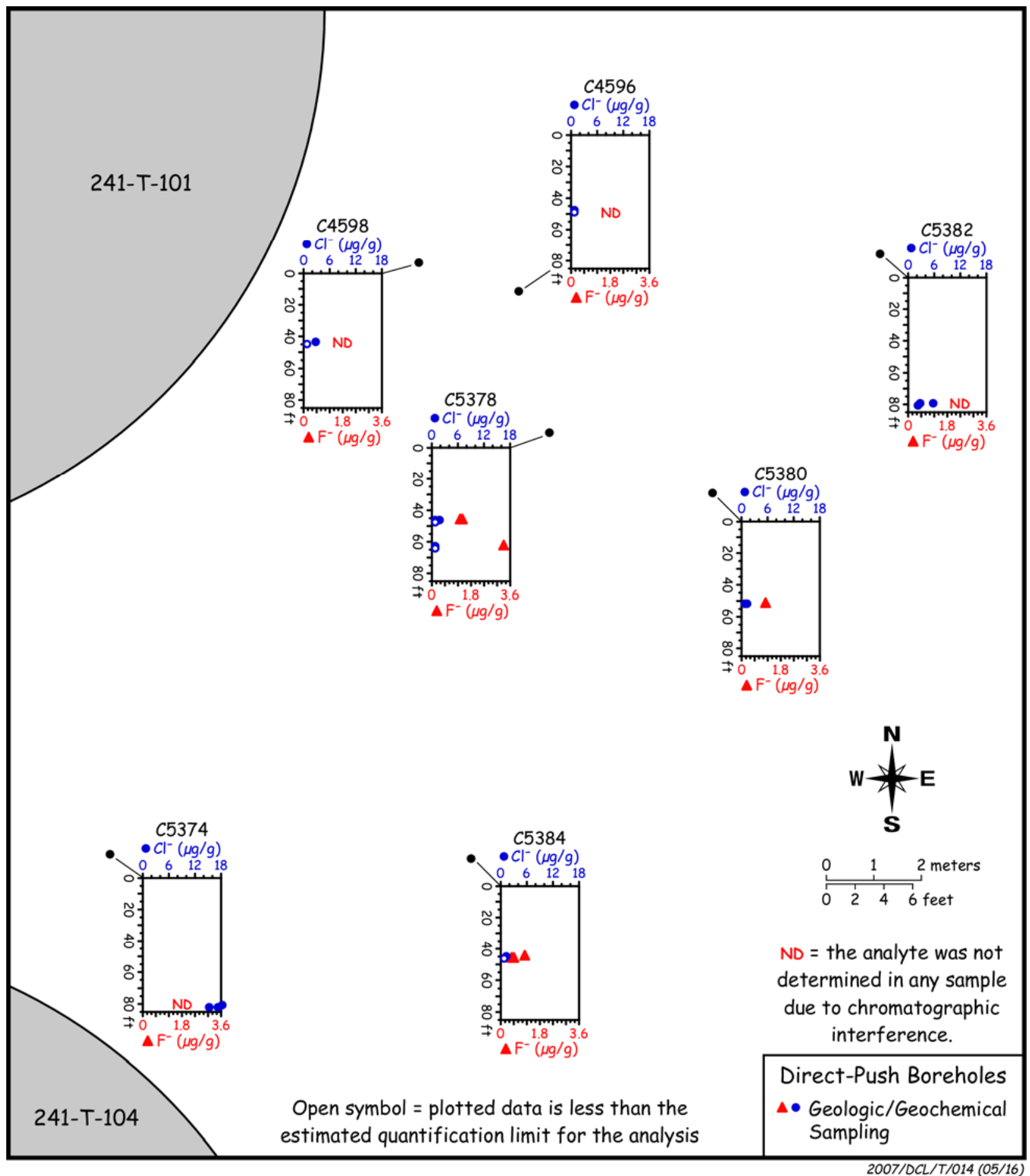

Figure 4.12. 1:1 Sediment:Water-Extractable Chloride and Fluoride Data from the T Tank Farm Direct Push Samples 
Table 4.19. Water-Extractable Major Cations in the T Tank Farm Core and Grab Samples ( $\mu \mathrm{g} / \mathrm{g}$ dry sediment)

\begin{tabular}{|c|c|c|c|c|c|c|c|}
\hline $\begin{array}{l}\text { Sample } \\
\text { ID }\end{array}$ & $\begin{array}{c}\text { Probe Hole } \\
\text { ID }\end{array}$ & $\begin{array}{c}\text { Mid-Depth } \\
\mathrm{ft} \text { bgs }\end{array}$ & $\begin{array}{c}\text { Calcium } \\
\mu \mathrm{g} / \mathrm{g}\end{array}$ & $\begin{array}{c}\text { Potassium } \\
\mu \mathrm{g} / \mathrm{g}\end{array}$ & $\begin{array}{c}\text { Magnesium } \\
\mu \mathrm{g} / \mathrm{g}\end{array}$ & $\begin{array}{c}\text { Strontium } \\
\mu \mathrm{g} / \mathrm{g}\end{array}$ & $\begin{array}{c}\text { Sodium } \\
\mu \mathrm{g} / \mathrm{g}\end{array}$ \\
\hline B1KC35A & C4598 & 43.8 & $4.59 E-01$ & $(2.48 \mathrm{E}+00)$ & $(8.05 \mathrm{E}-02)$ & (3.04E-03) & $1.76 \mathrm{E}+02$ \\
\hline $\mathrm{B} 1 \mathrm{KC} 35 \mathrm{~B}$ & C4598 & 43.3 & $5.49 E-01$ & $(3.49 \mathrm{E}+00)$ & $(1.02 \mathrm{E}-01)$ & $(3.25 \mathrm{E}-03)$ & $1.82 E+02$ \\
\hline B1KC36A & C4596 & 48.3 & $8.54 E-01$ & $(2.01 \mathrm{E}+00)$ & $(1.94 \mathrm{E}-01)$ & $(5.15 \mathrm{E}-03)$ & $1.79 \mathrm{E}+02$ \\
\hline $\mathrm{B} 1 \mathrm{KC} 36 \mathrm{~B}$ & C4596 & 47.8 & $9.48 E-01$ & $(1.65 \mathrm{E}+00)$ & $(9.04 \mathrm{E}-02)$ & $(5.01 \mathrm{E}-03)$ & $1.48 \mathrm{E}+02$ \\
\hline B1KC36C & C4596 & 47.3 & $5.23 E-01$ & $(1.66 \mathrm{E}+00)$ & $\begin{array}{l}(7.72 \mathrm{E}-02) \\
\end{array}$ & (3.30E-03) & $1.43 E+02$ \\
\hline B1KC37A & C5378 & 46.3 & $7.25 E-01$ & $(1.73 \mathrm{E}+00)$ & $\begin{array}{l}(1.95 \mathrm{E}-01) \\
\end{array}$ & (5.29E-03) & $6.52 E+01$ \\
\hline B1KC37B & C5378 & 45.8 & $7.01 E-01$ & $(1.84 \mathrm{E}+00)$ & $(1.58 \mathrm{E}-01)$ & $(4.30 \mathrm{E}-03)$ & $7.40 \mathrm{E}+01$ \\
\hline B1KC37C & C5378 & 45.3 & $1.79 E+00$ & $(3.14 \mathrm{E}+00)$ & $5.58 E-01$ & (8.07E-03) & $4.06 \mathrm{E}+01$ \\
\hline B1KC38A & C5378 & 63.3 & $6.52 E-01$ & $(1.84 \mathrm{E}+00)$ & $(6.51 \mathrm{E}-02)$ & $(3.72 \mathrm{E}-03)$ & $1.91 \mathrm{E}+02$ \\
\hline $\mathrm{B} 1 \mathrm{KC} 38 \mathrm{~B}$ & C5378 & 62.8 & $6.01 E-01$ & $(1.66 \mathrm{E}+00)$ & $(6.25 \mathrm{E}-02)$ & $(3.10 \mathrm{E}-03)$ & $2.11 E+02$ \\
\hline $\mathrm{B} 1 \mathrm{KC} 38 \mathrm{C}$ & C5378 & 62.3 & $1.08 E+00$ & $(2.25 \mathrm{E}+00)$ & $(1.03 \mathrm{E}-01)$ & $(5.41 \mathrm{E}-03)$ & $2.55 E+02$ \\
\hline B1KC39A & C5384 & 45.3 & $2.02 E+00$ & $(2.82 \mathrm{E}+00)$ & $5.02 E-01$ & $(1.16 \mathrm{E}-02)$ & $3.18 \mathrm{E}+01$ \\
\hline B1KC39B & C5384 & 44.8 & $2.25 E+00$ & $(2.90 \mathrm{E}+00)$ & $5.63 E-01$ & $(1.29 \mathrm{E}-02)$ & $3.30 \mathrm{E}+01$ \\
\hline B1KC39C & C5384 & 44.3 & $3.71 E+00$ & $(4.58 \mathrm{E}+00)$ & $9.71 E-01$ & $(1.99 \mathrm{E}-02)$ & $4.09 \mathrm{E}+01$ \\
\hline $\mathrm{B} 1 \mathrm{KC} 40 \mathrm{~A}$ & C5374 & 81.3 & $1.05 E+02$ & 8.77E+00 & $2.30 \mathrm{E}+01$ & 4.80E-01 & $3.91 \mathrm{E}+01$ \\
\hline $\mathrm{B} 1 \mathrm{KC} 40 \mathrm{~B}$ & C5374 & 80.8 & $9.19 \mathrm{E}+01$ & 8.14E+00 & 2.03E+01 & 4.26E-01 & $3.22 \mathrm{E}+01$ \\
\hline $\mathrm{B} 1 \mathrm{KC} 40 \mathrm{C}$ & C5374 & 80.3 & $1.06 \mathrm{E}+02$ & $1.08 \mathrm{E}+01$ & $2.52 \mathrm{E}+01$ & 5.17E-01 & $2.66 \mathrm{E}+01$ \\
\hline B1LB07A & C5382 & 79.3 & $1.51 E+01$ & $(4.92 \mathrm{E}+00)$ & $3.35 E+00$ & $8.00 E-02$ & $3.00 \mathrm{E}+01$ \\
\hline B1LB07B & C5382 & 78.8 & $1.10 E+01$ & $(4.28 \mathrm{E}+00)$ & $2.35 E+00$ & $5.34 E-02$ & $2.94 \mathrm{E}+01$ \\
\hline B1LB07C & C5382 & 78.3 & $7.56 E+00$ & $(3.82 \mathrm{E}+00)$ & $1.68 E+00$ & $4.11 E-02$ & $2.70 \mathrm{E}+01$ \\
\hline B1LB08A & C5380 & 51.3 & $9.82 E-01$ & $(3.91 \mathrm{E}+00)$ & $(1.73 \mathrm{E}-01)$ & $(4.84 \mathrm{E}-03)$ & $6.10 \mathrm{E}+01$ \\
\hline B1LB08B & C5380 & 50.8 & $9.23 E-01$ & $(4.62 \mathrm{E}+00)$ & $(1.63 \mathrm{E}-01)$ & $(4.52 \mathrm{E}-03)$ & $6.17 E+01$ \\
\hline B1LB08C & C5380 & 50.3 & $1.08 E+00$ & $(4.31 \mathrm{E}+00)$ & $(2.49 \mathrm{E}-01)$ & (5.32E-03) & $6.36 \mathrm{E}+01$ \\
\hline
\end{tabular}

The water extract data for potentially mobile metals, such as technetium-99, uranium-238, chromium, molybdenum, and ruthenium, are shown in Table 4.21. Additionally, the water-extractable technetium-99 and uranium-238 are plotted as a function of depth in Figures 4.14 and 4.15. Water-extractable technetium-99 was found in most of the direct push core samples analyzed; however, it was only significantly elevated $(79.5 \mathrm{pCi} / \mathrm{g})$ in the sediments collected from probe hole C5374. Not surprisingly, these were some of the deepest direct push samples collected as part of the T Tank Farm sampling campaign. Technetium-99 is generally considered quite mobile in the subsurface, and as such, peak concentrations in the vadose zone are often found well below $115 \mathrm{ft}$ bgs in regions that have been contaminated by tank loss events (Serne et al. 2004b, Brown et al. 2006). Water-leachable uranium-238 was all less than $0.2 \mu \mathrm{g} / \mathrm{g}$, indicating that there is not a significant amount of contaminant uranium in the vadose zone at these sampling locations. However, uranium was not estimated to be a significant component of the waste that was allegedly lost during the tank 241-T-101 leak event (Wood et al. 2001).

Elevated water-leachable chromium (nearly $4 \mu \mathrm{g} / \mathrm{g}$ ) was also found in sediments from probe hole C5374. For comparative purposes, the average water-leachable chromium values for all of the remaining $\mathrm{T}$ Tank Farm direct push samples were less than $0.1 \mu \mathrm{g} / \mathrm{g}$. The three core samples from probe hole C5374 also had elevated water-extractable ruthenium. Furthermore, differences between the measured ruthenium-101 and ruthenium-102 concentrations indicate that the ruthenium is present as a fission product produced during the fuel burn-up cycle. These three samples are excellent candidates for performing ruthenium isotopic analysis for source identification. 


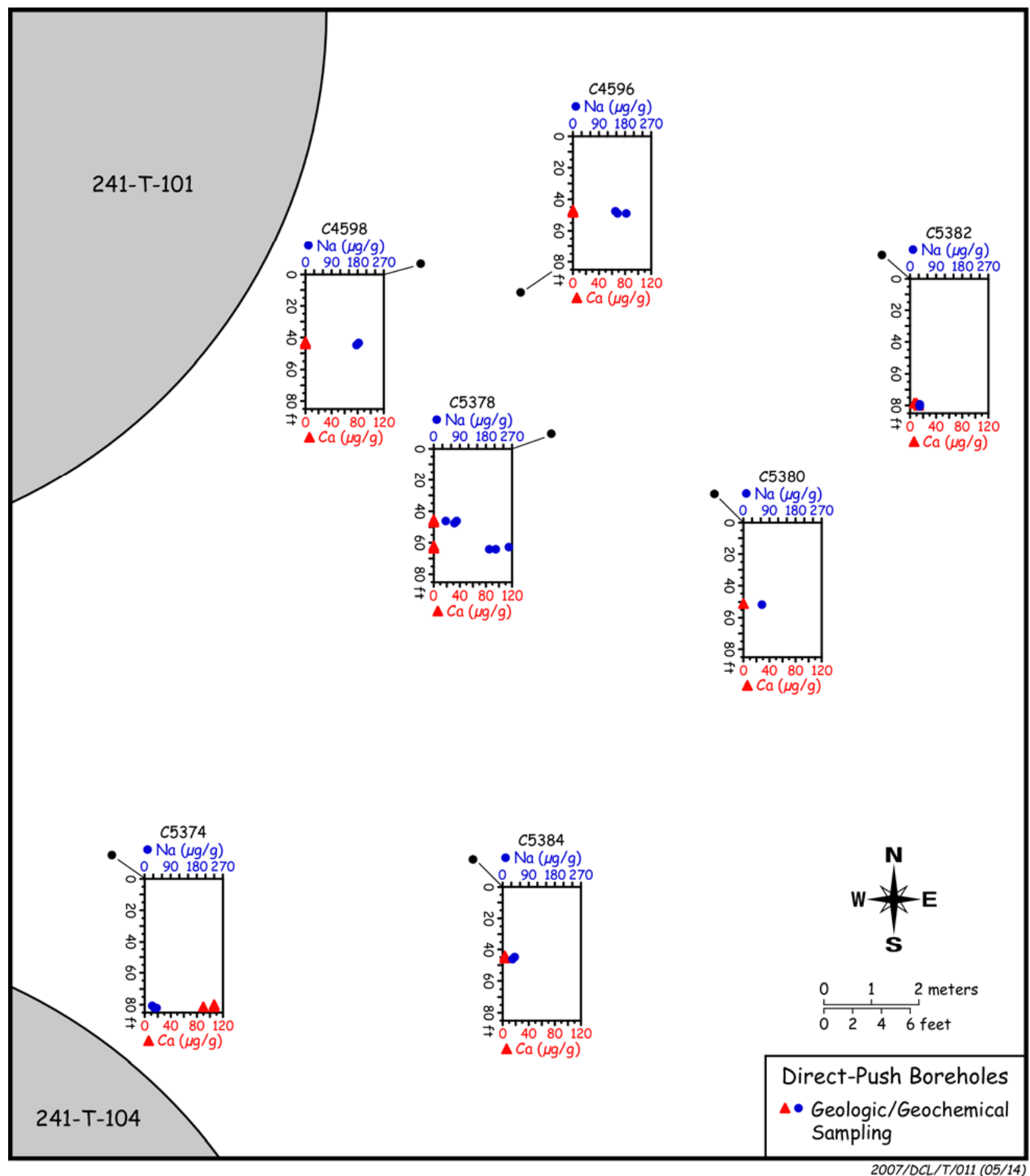

Figure 4.13. 1:1 Sediment:Water-Extractable Sodium and Calcium data from the T Tank Farm Direct Push Samples 
Table 4.20. Water-Extractable Cations in the T Tank Farm Core and Grab Samples ( $\mu \mathrm{g} / \mathrm{g}$ dry sediment)

\begin{tabular}{|c|c|c|c|c|c|c|}
\hline $\begin{array}{l}\text { Sample } \\
\text { ID }\end{array}$ & $\begin{array}{l}\text { Probe Hole } \\
\text { ID }\end{array}$ & $\begin{array}{l}\text { Mid-Depth } \\
\mathrm{ft} \text { bgs }\end{array}$ & $\begin{array}{c}\text { Aluminum } \\
\mu \mathrm{g} / \mathrm{g}\end{array}$ & $\begin{array}{l}\text { Iron } \\
\mu \mathrm{g} / \mathrm{g}\end{array}$ & $\begin{array}{c}\text { Sulfur as } \mathrm{SO}_{4}^{2-} \\
\mu \mathrm{g} / \mathrm{g}\end{array}$ & $\begin{array}{c}\text { Silicon } \\
\mu \mathrm{g} / \mathrm{g}\end{array}$ \\
\hline "B1KC35A & C4598 & "43.8 & $2.71 \mathrm{E}-01$ & "3.34E-01 & 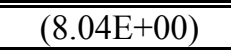 & $2.19 \mathrm{E}+01$ \\
\hline B1KC35B & C4598 & 43.3 & $2.76 \mathrm{E}-01$ & $3.08 \mathrm{E}-01$ & $1.96 \mathrm{E}+01$ & $1.51 \mathrm{E}+01$ \\
\hline B1KC36A & C4596 & 48.3 & $3.30 \mathrm{E}-01$ & $2.11 \mathrm{E}-01$ & $(1.28 \mathrm{E}+01)$ & $1.25 \mathrm{E}+01$ \\
\hline $\mathrm{B} 1 \mathrm{KC} 36 \mathrm{~B}$ & C4596 & 47.8 & $2.25 \mathrm{E}-01$ & $2.41 \mathrm{E}-01$ & $(1.08 \mathrm{E}+01)$ & $1.82 \mathrm{E}+01$ \\
\hline $\mathrm{B} 1 \mathrm{KC} 36 \mathrm{C}$ & C4596 & 47.3 & $2.45 \mathrm{E}-01$ & $2.85 \mathrm{E}-01$ & $(8.71 \mathrm{E}+00)$ & $2.17 \mathrm{E}+01$ \\
\hline B1KC37A & C5378 & 46.3 & $3.92 \mathrm{E}-01$ & $4.62 \mathrm{E}-01$ & $(8.54 \mathrm{E}+00)$ & $1.61 \mathrm{E}+01$ \\
\hline B1KC37B & $\begin{array}{l}\mathrm{C} 5378 \\
\end{array}$ & 45.8 & $1.82 \mathrm{E}-01$ & $1.65 \mathrm{E}-01$ & $(9.49 \mathrm{E}+00)$ & $1.51 \mathrm{E}+01$ \\
\hline $\mathrm{B} 1 \mathrm{KC} 37 \mathrm{C}$ & C5378 & 45.3 & $1.53 \mathrm{E}-01$ & $1.92 \mathrm{E}-01$ & $1.75 \mathrm{E}+01$ & $1.55 \mathrm{E}+01$ \\
\hline B1KC38A & C5378 & 63.3 & $1.98 \mathrm{E}-01$ & $2.33 \mathrm{E}-01$ & $(7.79 \mathrm{E}+00)$ & $1.82 \mathrm{E}+01$ \\
\hline B1KC38B & C5378 & 62.8 & $1.68 \mathrm{E}-01$ & $2.20 \mathrm{E}-01$ & $(1.00 \mathrm{E}+01)$ & $2.05 \mathrm{E}+01$ \\
\hline B1KC38C & C5378 & 62.3 & $1.62 \mathrm{E}-01$ & $2.62 \mathrm{E}-01$ & $1.64 \mathrm{E}+01$ & $1.85 \mathrm{E}+01$ \\
\hline B1KC39A & C5384 & 45.3 & $1.38 \mathrm{E}-01$ & $1.29 \mathrm{E}-01$ & $(8.84 \mathrm{E}+00)$ & $9.82 \mathrm{E}+00$ \\
\hline B1KC39B & C5384 & 44.8 & $1.29 \mathrm{E}-01$ & $1.36 \mathrm{E}-01$ & $(9.02 \mathrm{E}+00)$ & $1.08 \mathrm{E}+01$ \\
\hline B1KC39C & C5384 & 44.3 & $9.67 \mathrm{E}-02$ & $9.27 \mathrm{E}-02$ & $1.66 \mathrm{E}+01$ & $8.41 \mathrm{E}+00$ \\
\hline $\mathrm{B} 1 \mathrm{KC} 40 \mathrm{~A}$ & C5374 & 81.3 & $<2.54 E-02$ & $(2.24 E-03)$ & $1.12 E+02$ & $1.08 \mathrm{E}+01$ \\
\hline $\mathrm{B} 1 \mathrm{KC} 40 \mathrm{~B}$ & C5374 & 80.8 & $<2.54 E-02$ & $(4.24 E-03)$ & $1.00 \mathrm{E}+02$ & $1.05 \mathrm{E}+01$ \\
\hline $\mathrm{B} 1 \mathrm{KC} 40 \mathrm{C}$ & C5374 & 80.3 & $<2.52 E-02$ & $(3.10 E-03)$ & $9.09 \mathrm{E}+01$ & $9.59 \mathrm{E}+00$ \\
\hline$\overline{B 1 L B 07 A}$ & C5382 & 79.3 & $(1.78 \mathrm{E}-02)$ & $3.41 \mathrm{E}-02$ & $2.62 \mathrm{E}+01$ & $1.34 \mathrm{E}+01$ \\
\hline B1LB07B & C5382 & 78.8 & $7.43 \mathrm{E}-02$ & $6.81 \mathrm{E}-02$ & $1.78 \mathrm{E}+01$ & $1.34 \mathrm{E}+01$ \\
\hline B1LB07C & C5382 & 78.3 & $3.86 \mathrm{E}-02$ & $3.82 \mathrm{E}-02$ & $(1.33 \mathrm{E}+01)$ & $1.14 \mathrm{E}+01$ \\
\hline B1LB08A & C5380 & 51.3 & $1.35 \mathrm{E}-01$ & $1.52 \mathrm{E}-01$ & $(1.20 \mathrm{E}+01)$ & $1.33 \mathrm{E}+01$ \\
\hline B1LB08B & C5380 & 50.8 & $2.15 \mathrm{E}-01$ & $2.78 \mathrm{E}-01$ & $(8.56 \mathrm{E}+00)$ & $1.24 \mathrm{E}+01$ \\
\hline B1LB08C & C5380 & 50.3 & $2.40 \mathrm{E}-01$ & $2.87 \mathrm{E}-01$ & $(7.47 \mathrm{E}+00)$ & $1.12 \mathrm{E}+01$ \\
\hline
\end{tabular}


Table 4.21. Water-Extractable Mobile Metals in the T Tank Farm Core and Grab Samples ( $\mu \mathrm{g} / \mathrm{g}$ dry sediment)

\begin{tabular}{|c|c|c|c|c|c|c|c|c|}
\hline $\begin{array}{l}\text { Sample } \\
\text { ID }\end{array}$ & $\begin{array}{l}\text { Probe Hole } \\
\text { ID }\end{array}$ & $\begin{array}{l}\text { Mid-Depth } \\
\text { ft bgs }\end{array}$ & $\begin{array}{c}\text { Technetium-99 } \\
\text { pCi/g }\end{array}$ & $\begin{array}{c}\text { Uranium-238 } \\
\mu \mathrm{g} / \mathrm{g}\end{array}$ & $\begin{array}{c}\text { Chromium-52 } \\
\mu \mathrm{g} / \mathrm{g}\end{array}$ & $\begin{array}{c} \\
\mathrm{g} / \mathrm{g}\end{array}$ & $\begin{array}{c}\text { Ruthenium-101 } \\
\mu \mathrm{g} / \mathrm{g}\end{array}$ & $\begin{array}{c}\text { Ruthenium-102 } \\
\mu \mathrm{g} / \mathrm{g}\end{array}$ \\
\hline B1KC35A & בC4598 & 43.8 & 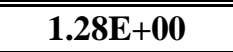 & $\begin{array}{l}1.10 \mathrm{E}-01 \\
\end{array}$ & $\begin{array}{l}1.16 \mathrm{E}-02 \\
\end{array}$ & 3.06E-02 & (1.25E-04) & (2.71E-05) \\
\hline B1KC35B & C4598 & 43.3 & $1.75 E+00$ & $1.40 \mathrm{E}-01$ & $6.48 \mathrm{E}-03$ & $2.21 \mathrm{E}-01$ & $(1.07 \mathrm{E}-04)$ & $(4.03 \mathrm{E}-06)$ \\
\hline B1KC36A & C4596 & 48.3 & 4.87E-01 & 3.04E-02 & 3.64E-02 & $6.81 \mathrm{E}-02$ & (3.66E-04) & $(1.54 \mathrm{E}-04)$ \\
\hline B1KC36B & C4596 & 47.8 & 2.95E-01 & $1.63 \mathrm{E}-02$ & $3.46 \mathrm{E}-02$ & $3.44 \mathrm{E}-02$ & $(3.56 \mathrm{E}-04)$ & $(1.26 \mathrm{E}-04)$ \\
\hline B1KC36C & C4596 & 47.3 & 5.93E-01 & $1.66 \mathrm{E}-02$ & $8.22 \mathrm{E}-03$ & $3.12 \mathrm{E}-02$ & (7.04E-05) & $(9.60 \mathrm{E}-06)$ \\
\hline $\mathrm{B} 1 \mathrm{KC} 37 \mathrm{~A}$ & C5378 & 46.3 & 9.86E-02 & $1.81 \mathrm{E}-02$ & $7.87 \mathrm{E}-03$ & $2.50 \mathrm{E}-02$ & $(6.23 \mathrm{E}-05)$ & $<1.04 \mathrm{E}-03$ \\
\hline B1KC37B & C5378 & 45.8 & 1.19E-01 & $1.93 \mathrm{E}-02$ & $1.45 \mathrm{E}-02$ & $2.83 \mathrm{E}-02$ & $(1.75 \mathrm{E}-04)$ & $(7.20 \mathrm{E}-05)$ \\
\hline $\mathrm{B} 1 \mathrm{KC} 37 \mathrm{C}$ & C5378 & 45.3 & $5.48 \mathrm{E}-02$ & $2.73 \mathrm{E}-03$ & $2.06 \mathrm{E}-02$ & $7.69 \mathrm{E}-02$ & $(2.42 \mathrm{E}-05)$ & $<1.01 \mathrm{E}-03$ \\
\hline B1KC38A & C5378 & 63.3 & $2.26 \mathrm{E}+00$ & $1.07 \mathrm{E}-01$ & $6.15 \mathrm{E}-02$ & 1.99E-02 & $(5.95 \mathrm{E}-04)$ & $(2.56 \mathrm{E}-04)$ \\
\hline B1KC38B & $\begin{array}{l}\mathrm{C} 5378 \\
\end{array}$ & 62.8 & $1.48 \mathrm{E}+00$ & $1.23 \mathrm{E}-01$ & $7.90 \mathrm{E}-02$ & $3.21 \mathrm{E}-02$ & $(4.26 \mathrm{E}-04)$ & $\begin{array}{l}(1.45 \mathrm{E}-04) \\
\end{array}$ \\
\hline B1KC38C & C5378 & 62.3 & $1.41 E+00$ & $1.84 \mathrm{E}-01$ & $8.28 \mathrm{E}-02$ & $9.43 \mathrm{E}-02$ & (7.61E-04) & (3.04E-04) \\
\hline B1KC39A & C5384 & 45.3 & $<3.43 \mathrm{E}-02$ & $2.07 \mathrm{E}-03$ & $(1.56 \mathrm{E}-03)$ & $2.17 \mathrm{E}-02$ & $<1.01 \mathrm{E}-03$ & $<1.01 \mathrm{E}-03$ \\
\hline B1KC39B & C5384 & 44.8 & $<3.46 \mathrm{E}-02$ & $2.47 \mathrm{E}-03$ & $(1.25 \mathrm{E}-03)$ & $2.43 \mathrm{E}-02$ & $(1.43 \mathrm{E}-05)$ & $<1.02 \mathrm{E}-03$ \\
\hline B1KC39C & C5384 & 44.3 & $(2.04 \mathrm{E}-02)$ & $2.11 \mathrm{E}-03$ & $(1.41 \mathrm{E}-03)$ & $1.67 \mathrm{E}-01$ & $<1.00 \mathrm{E}-03$ & $<1.00 \mathrm{E}-03$ \\
\hline B1KC40A & C5374 & 81.3 & $7.91 \mathrm{E}+01$ & $2.08 \mathrm{E}-03$ & $3.88 \mathrm{E}+00$ & 1.79E-02 & 3.35E-03 & 1.72E-03 \\
\hline $\mathrm{B} 1 \mathrm{KC} 40 \mathrm{~B}$ & C5374 & 80.8 & $7.95 \mathrm{E}+01$ & $1.86 \mathrm{E}-03$ & $3.94 \mathrm{E}+00$ & $1.52 \mathrm{E}-02$ & 4.02E-03 & 2.06E-03 \\
\hline $\mathrm{B} 1 \mathrm{KC} 40 \mathrm{C}$ & C5374 & 80.3 & $1.74 \mathrm{E}+01$ & $1.65 \mathrm{E}-03$ & $9.60 \mathrm{E}-02$ & $6.93 \mathrm{E}-02$ & 3.87E-03 & 2.11E-03 \\
\hline B1LB07A & C5382 & 79.3 & 1.12E-01 & 3.70E-03 & (4.02E-03) & $7.30 \mathrm{E}-02$ & $<1.00 \mathrm{E}-03$ & $<1.00 \mathrm{E}-03$ \\
\hline B1LB07B & C5382 & 78.8 & 2.82E-02 & $3.47 \mathrm{E}-03$ & (3.09E-03) & $8.62 \mathrm{E}-02$ & $<1.04 \mathrm{E}-03$ & $<1.04 \mathrm{E}-03$ \\
\hline B1LB07C & C5382 & 78.3 & $<3.41 \mathrm{E}-02$ & $2.35 \mathrm{E}-03$ & $(6.57 \mathrm{E}-04)$ & $6.56 \mathrm{E}-02$ & $<1.00 \mathrm{E}-03$ & $<1.00 \mathrm{E}-03$ \\
\hline B1LB08A & C5380 & 51.3 & $(1.75 \mathrm{E}-02)$ & $1.25 \mathrm{E}-02$ & $(1.71 \mathrm{E}-03)$ & 7.31E-02 & $(4.23 \mathrm{E}-05)$ & $<1.03 \mathrm{E}-03$ \\
\hline B1LB08B & C5380 & 50.8 & 2.84E-02 & $1.68 \mathrm{E}-02$ & $(2.55 \mathrm{E}-03)$ & $8.10 \mathrm{E}-02$ & $(5.03 \mathrm{E}-05)$ & $<1.05 \mathrm{E}-03$ \\
\hline B1LB08C & C5380 & 50.3 & 6.57E-02 & $1.33 \mathrm{E}-02$ & $(2.22 \mathrm{E}-03)$ & $1.08 \mathrm{E}-01$ & (7.14E-05) & $<1.02 \mathrm{E}-03$ \\
\hline
\end{tabular}




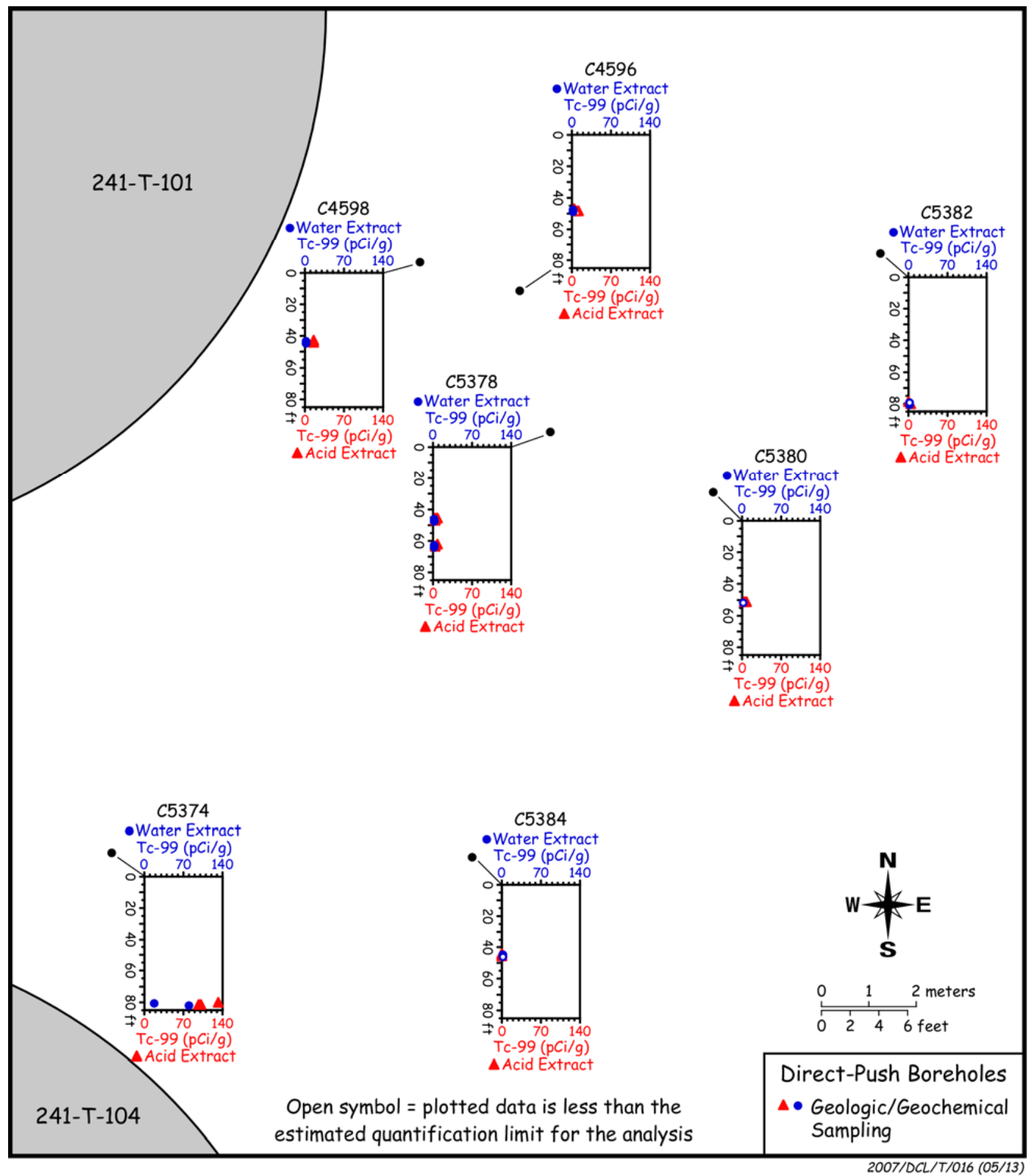

Figure 4.14. 1:1 Sediment:Water-Extractable and 8M Nitric Acid Extractable Technetium-99 data from the T Tank Farm Direct Push Samples 


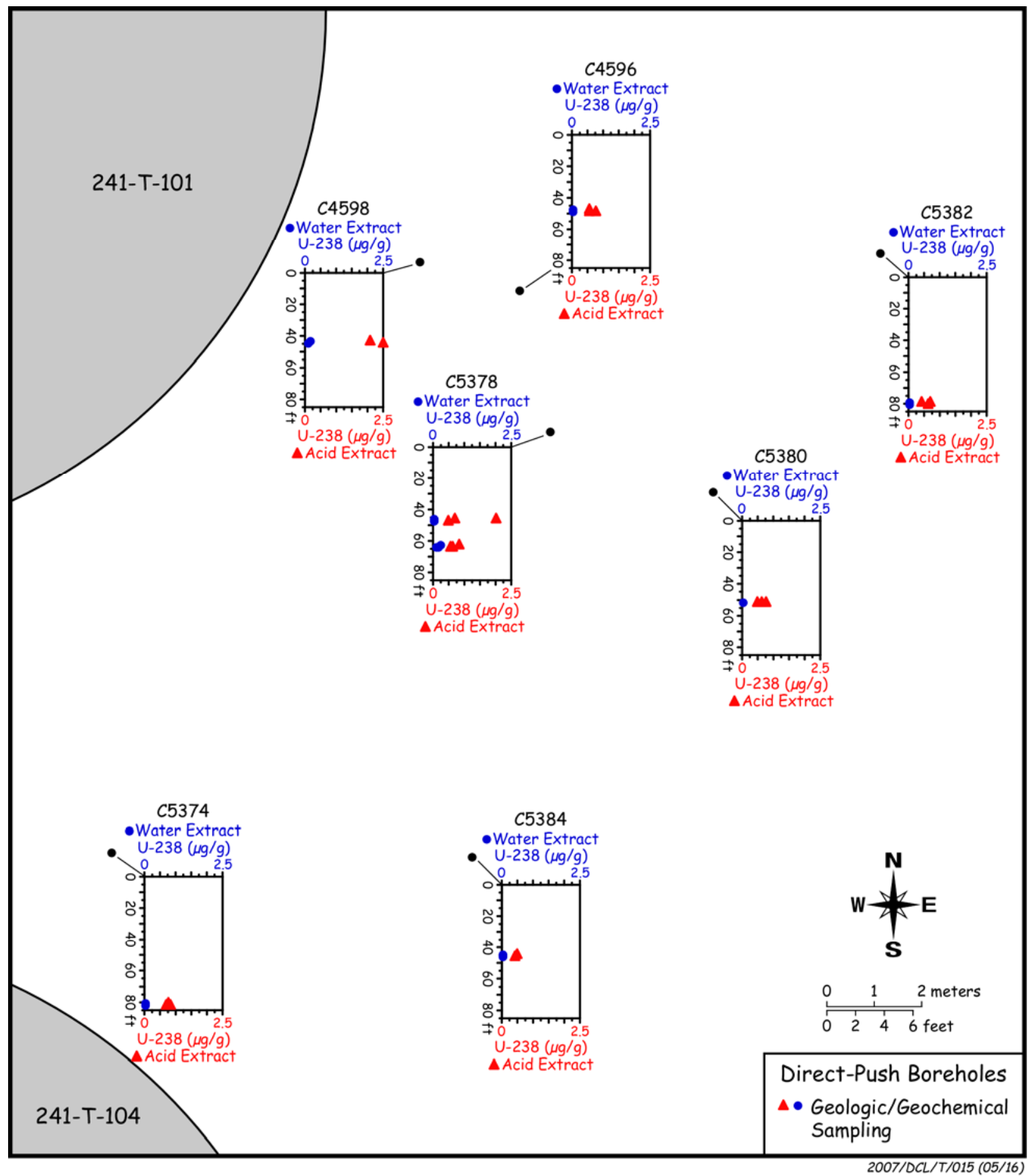

Figure 4.15. 1:1 Sediment:Water-Extractable and 8M Nitric Acid Extractable Uranium-238 data from the T Tank Farm Direct Push Samples 


\subsubsection{Vadose Zone Porewater Chemical Composition}

The 1:1 water extract data was manipulated to derive the pore water composition of the vadose zone sediments so that electrical balances (anions vs. cations) of the samples could be evaluated. From knowledge of the moisture content of the sediment samples taken from the liners of each direct push sample and the grab samples, the amount of de-ionized water that would be needed to make the water extract exactly one part water (total of native pore water and added de-ionized water) to one part by weight dry sediment was calculated. The ratio of the total volume of water in the extract to the native mass of pore water is the dilution factor. An assumption was made that the de-ionized water acted solely as a diluent of the existing pore water and that the de-ionized water did not dissolve any of the solids in the sediments. Thus by correcting for the dilution, an estimate of the actual chemical composition of the native pore-water in the vadose zone sediments could be derived.

Tables 4.22 and 4.23 show the derived pore water composition of key constituents in meq/L and Figure 4.16 shows the porewater corrected alkalinity $\left(\mathrm{as}_{\mathrm{CaCO}}\right)$ in units of $\mathrm{mg} / \mathrm{L}$. The highest dissolved salt loads were found in the sediment collected within probe hole $\mathrm{C} 4598$, which was one of the closest locations to the side of T-101 sampled. The sediment was collected from approximately $43 \mathrm{ft}$ bgs and had some of the highest $\mathrm{pH}$ values measured in the T Tank Farm direct push samples. As a result of the high $\mathrm{pH}$, carbon dioxide was absorbed by the porewater present in the sediment and resulted in the majority of the anionic charge being attributed to alkalinity $(192 \mathrm{meq} / \mathrm{L})$. The remainder of the dissolved anionic species were sulfate $(3.05 \mathrm{meq} / \mathrm{L})$, nitrate $(1.82 \mathrm{meq} / \mathrm{L})$, and phosphate $(1.65 \mathrm{meq} / \mathrm{L})$, for a total anionic charge of $199 \mathrm{meq} / \mathrm{L}$. The anions in this samples were primarily balanced by sodium $(193 \mathrm{meq} / \mathrm{L})$, with trace amounts of calcium $(0.576 \mathrm{meq} / \mathrm{L})$. These concentrations are very dilute compared to the vadose zone pore waters found at the SX and BX tank farms, where the total dissolved slat loads were as high as 7,000 to 17,000 and $1,000 \mathrm{meq} / \mathrm{L}$, respectively. The most concentrated pore waters below tank T-106 ranged from 200 to $250 \mathrm{meq} / \mathrm{L}$ each for cations and anions (total $\sim 450$ to $500 \mathrm{meq} / \mathrm{L}$ ) and below tank TX-107, the most concentrated pore water had 850 total meq/L.

The samples that had the highest concentrations of mobile tank waste constituents (namely technetium-99 and nitrate) were found in probe hole C5374. The sample with the peak dissolved salt load in the three liners from probe hole $\mathrm{C} 5374$ contained $62 \mathrm{meq} / \mathrm{L}$ anions and $59 \mathrm{meq} / \mathrm{L}$ cations. The dissolved anions included nitrate $(35.9 \mathrm{meq} / \mathrm{L})$, sulfate $(13.2 \mathrm{meq} / \mathrm{L})$, alkalinity $(9.27 \mathrm{meq} / \mathrm{L})$, and chloride $(3.10 \mathrm{meq} / \mathrm{L})$. The dissolved anions were balanced by calcium $(35.4 \mathrm{meq} / \mathrm{L})$, magnesium $(19.2 \mathrm{meq} / \mathrm{L})$, sodium $(7.79 \mathrm{meq} / \mathrm{L})$, and potassium $1.92 \mathrm{meq} / \mathrm{L})$. Again, these samples were quite dilute when compared to contaminated sediments collected during other characterization campaigns; including the T-106 boreholes C4104 and C4105 (see Serne et al. (2004b).

Overall, the calculated charge balance between cations and anions for all of the samples was quite good (less than $10 \%$ difference for most of the samples analyzed). However, samples from probe holes C5378, C5380, C5382, and C5384 contained in general 10-20\% less dissolved cations than anions. Based on comparison of this data, it appears that either the bicarbonate measurement for these samples is biased high, or analyses have not accounted for a dissolved metal that is present in sufficient quantity to properly balance the electrical charge of these samples.

As mentioned previously, sodium was present as the dominant cation in all of the samples except those from probe hole $\mathrm{C} 5374$, which contained calcium as the dominant cation. Bicarbonate (measured as alkalinity via titration) was the primary anionic species in all of the samples except those from probe 
hole $\mathrm{C} 5374$, which contained nitrate as the dominant anion. The lack of samples containing calcium as the dominant cation indicates that the samples in this region have been impacted by a sodium-bearing waste fluid. The source(s) appears to be a moderately concentrated sodium-bearing waste solution that has displaced the natural divalent cations from the sediment cation exchange sites in the sediments. The total vertical extent of the ion exchange front is unknown due to the lack of sediment samples from deeper in the vadose zone.

The porewater-corrected concentrations of mobile metals are presented in Table 4.24 in units of pCi/L (for teachnetium-99) or $\mu \mathrm{g} / \mathrm{L}$ (for all other constituents). A porewater-corrected technetium-99 activity in excess of 45,000 $\mathrm{pCi} / \mathrm{L}$ was measured in one sample from probe hole $\mathrm{C} 5374$. Although an activity of $45,000 \mathrm{pCi} / \mathrm{L}$ is 50 times the maximum contaminant level (MCL) for technetium-99, it is important to note that this value represents a porewater concentration and would be diluted significantly should the solution make it to the water table. The other thing to note is that while there was a relatively small amount of water-extractable uranium-238 present in these samples, the porewater-corrected uranium-238 concentrations exceeded the MCL of $30 \mu \mathrm{g} / \mathrm{L}$ in nearly all of the samples analyzed. Again, these porewater-corrected concentrations would be significantly diluted should these solutions ever reach the water table.

Table 4.22. Calculated Pore Water Anion Concentrations in the T Tank Farm Core and Grab Samples

\begin{tabular}{|c|c|c|c|c|c|c|c|c|}
\hline $\begin{array}{l}\text { Sample } \\
\text { ID } \\
\end{array}$ & \begin{tabular}{|c|} 
Probe Hole \\
ID
\end{tabular} & $\begin{array}{c}\text { Mid-Depth } \\
\mathrm{ft} \text { bgs }\end{array}$ & $\begin{array}{c}\text { Fluoride } \\
\text { meq/L }\end{array}$ & $\begin{array}{c}\text { Chloride } \\
\text { meq/L }\end{array}$ & $\begin{array}{l}\text { Nitrate } \\
\mathrm{meq} / \mathrm{L}\end{array}$ & $\begin{array}{l}\text { Sulfate } \\
\mathrm{meq} / \mathrm{L}\end{array}$ & $\begin{array}{c}\text { Phosphate } \\
\text { meq/L }\end{array}$ & $\begin{array}{c}\text { Alkalinity } \\
\text { meq/L }\end{array}$ \\
\hline B1KC35A & C4598 & 43.8 & ND & $<3.56 \mathrm{E}-01$ & $1.82 \mathrm{E}+00$ & $3.05 \mathrm{E}+00$ & $1.65 \mathrm{E}+00$ & $1.92 \mathrm{E}+02$ \\
\hline $\mathrm{B} 1 \mathrm{KC} 35 \mathrm{~B}$ & C4598 & 43.3 & ND & $1.51 \mathrm{E}+00$ & $2.21 \mathrm{E}+00$ & $6.03 \mathrm{E}+00$ & ND & $1.71 \mathrm{E}+02$ \\
\hline B1KC36A & C4596 & 48.3 & ND & $<2.23 \mathrm{E}-01$ & $1.14 \mathrm{E}+00$ & $3.63 \mathrm{E}+00$ & $1.31 \mathrm{E}+00$ & $1.25 \mathrm{E}+02$ \\
\hline B1KC36B & C4596 & 47.8 & ND & $<3.48 \mathrm{E}-01$ & $8.10 \mathrm{E}-01$ & $3.99 \mathrm{E}+00$ & $<1.17 \mathrm{E}+00$ & $1.62 \mathrm{E}+02$ \\
\hline $\mathrm{B} 1 \mathrm{KC} 36 \mathrm{C}$ & C4596 & 47.3 & ND & $<3.29 \mathrm{E}-01$ & $7.28 \mathrm{E}-01$ & $3.69 \mathrm{E}+00$ & $1.13 \mathrm{E}+00$ & $1.44 \mathrm{E}+02$ \\
\hline B1KC37A & C5378 & 46.3 & ND & $<5.67 \mathrm{E}-01$ & $7.59 \mathrm{E}-01$ & $5.65 \mathrm{E}+00$ & $<1.90 \mathrm{E}+00$ & $1.22 \mathrm{E}+02$ \\
\hline B1KC37B & C5378 & 45.8 & $1.27 \mathrm{E}+00$ & $<2.40 \mathrm{E}-01$ & $5.55 \mathrm{E}-01$ & $2.88 \mathrm{E}+00$ & $<8.07 \mathrm{E}-01$ & $6.37 \mathrm{E}+01$ \\
\hline $\mathrm{B} 1 \mathrm{KC} 37 \mathrm{C}$ & C5378 & 45.3 & $6.05 \mathrm{E}-01$ & $3.73 \mathrm{E}-01$ & $4.96 \mathrm{E}-01$ & $2.84 \mathrm{E}+00$ & ND & $1.79 \mathrm{E}+01$ \\
\hline B1KC38A & C5378 & 63.3 & ND & $<2.81 \mathrm{E}-01$ & $2.60 \mathrm{E}+00$ & $2.32 \mathrm{E}+00$ & $<9.44 \mathrm{E}-01$ & $1.66 \mathrm{E}+02$ \\
\hline B1KC38B & C5378 & 62.8 & ND & $<2.60 \mathrm{E}-01$ & $1.91 \mathrm{E}+00$ & $2.64 \mathrm{E}+00$ & $1.12 \mathrm{E}+00$ & $1.69 \mathrm{E}+02$ \\
\hline B1KC38C & C5378 & 62.3 & $2.67 \mathrm{E}+00$ & $<2.23 \mathrm{E}-01$ & $1.10 \mathrm{E}+00$ & $4.16 \mathrm{E}+00$ & $1.25 \mathrm{E}+00$ & $1.68 \mathrm{E}+02$ \\
\hline B1KC39A & C5384 & 45.3 & 7.29E-01 & $<4.00 \mathrm{E}-01$ & $9.31 \mathrm{E}-01$ & $4.69 \mathrm{E}+00$ & $<1.34 \mathrm{E}+00$ & $4.91 \mathrm{E}+01$ \\
\hline B1KC39B & C5384 & 44.8 & $7.51 \mathrm{E}-01$ & $<3.17 \mathrm{E}-01$ & 9.74E-01 & $3.55 \mathrm{E}+00$ & $<1.07 \mathrm{E}+00$ & $4.58 \mathrm{E}+01$ \\
\hline B1KC39C & C5384 & 44.3 & $9.49 \mathrm{E}-01$ & 4.27E-01 & 4.83E-01 & $4.98 \mathrm{E}+00$ & ND & $3.60 \mathrm{E}+01$ \\
\hline B1KC40A & C5374 & 81.3 & ND & $2.88 \mathrm{E}+00$ & $2.86 \mathrm{E}+01$ & $1.47 \mathrm{E}+01$ & $<2.90 \mathrm{E}-01$ & $1.12 \mathrm{E}+01$ \\
\hline $\mathrm{B} 1 \mathrm{KC} 40 \mathrm{~B}$ & C5374 & 80.8 & ND & $2.36 \mathrm{E}+00$ & $2.35 \mathrm{E}+01$ & $1.19 \mathrm{E}+01$ & $<2.64 \mathrm{E}-01$ & $7.63 \mathrm{E}+00$ \\
\hline $\mathrm{B} 1 \mathrm{KC} 40 \mathrm{C}$ & C5374 & 80.3 & ND & $3.40 \mathrm{E}+00$ & $3.59 \mathrm{E}+01$ & $1.32 \mathrm{E}+01$ & $<3.21 \mathrm{E}-01$ & $9.27 \mathrm{E}+00$ \\
\hline B1LB07A & C5382 & 79.3 & ND & $2.64 \mathrm{E}-01$ & 7.98E-01 & $2.29 \mathrm{E}+00$ & $<2.10 \mathrm{E}-01$ & $9.15 \mathrm{E}+00$ \\
\hline B1LB07B & C5382 & 78.8 & ND & $4.82 \mathrm{E}-01$ & 7.26E-01 & $2.29 \mathrm{E}+00$ & ND & $1.42 \mathrm{E}+01$ \\
\hline B1LB07C & C5382 & 78.3 & ND & $2.64 \mathrm{E}+00$ & $4.45 \mathrm{E}-01$ & $4.22 \mathrm{E}+00$ & $<7.96 \mathrm{E}-01$ & $3.17 \mathrm{E}+01$ \\
\hline B1LB08A & C5380 & 51.3 & ND & $2.19 \mathrm{E}-01$ & $<2.00 \mathrm{E}-01$ & $2.38 \mathrm{E}+00$ & ND & $3.72 \mathrm{E}+01$ \\
\hline B1LB08B & C5380 & 50.8 & ND & $2.45 \mathrm{E}-01$ & $2.92 \mathrm{E}-01$ & $1.48 \mathrm{E}+00$ & ND & $3.38 \mathrm{E}+01$ \\
\hline B1LB08C & C5380 & 50.3 & $6.88 \mathrm{E}-01$ & $3.28 \mathrm{E}-01$ & $<1.99 \mathrm{E}-01$ & $1.41 \mathrm{E}+00$ & ND & $4.50 \mathrm{E}+01$ \\
\hline
\end{tabular}


Table 4.23. Calculated Pore Water Cation Concentrations in the T Tank Farm Direct Push Core and Grab Samples

\begin{tabular}{|c|c|c|c|c|c|c|}
\hline $\begin{array}{c}\text { Sample } \\
\text { ID }\end{array}$ & $\begin{array}{l}\text { Probe Hole } \\
\text { ID }\end{array}$ & $\begin{array}{l}\text { Mid-Depth } \\
\text { ft bgs }\end{array}$ & $\begin{array}{c}\begin{array}{c}\text { Calcium } \\
\text { meq/L }\end{array} \\
\text {. }\end{array}$ & $\begin{array}{c}\begin{array}{c}\text { Potassium } \\
\text { meq/L }\end{array} \\
\text {. }\end{array}$ & $\begin{array}{l}\text { Magnesium } \\
\text { meq/L }\end{array}$ & $\begin{array}{c}\begin{array}{c}\text { Sodium } \\
\text { meq/L }\end{array} \\
\end{array}$ \\
\hline B1KC35A & $\begin{array}{l}\text { C4598 } \\
\end{array}$ & 43.8 & $5.76 \mathrm{E}-01$ & 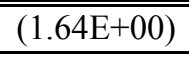 & 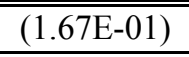 & $1.93 \mathrm{E}+02$ \\
\hline B1KC35B & C4598 & 43.3 & $6.38 \mathrm{E}-01$ & $(2.14 \mathrm{E}+00)$ & $\begin{array}{l}(1.95 \mathrm{E}-01) \\
\end{array}$ & $1.84 \mathrm{E}+02$ \\
\hline B1KC36A & C4596 & 48.3 & $6.69 \mathrm{E}-01$ & $(8.31 \mathrm{E}-01)$ & $(2.51 \mathrm{E}-01)$ & $1.22 \mathrm{E}+02$ \\
\hline B1KC36B & C4596 & 47.8 & $1.12 \mathrm{E}+00$ & $(1.03 \mathrm{E}+00)$ & $(1.77 \mathrm{E}-01)$ & $1.53 \mathrm{E}+02$ \\
\hline $\mathrm{B} 1 \mathrm{KC} 36 \mathrm{C}$ & C4596 & 47.3 & $5.71 \mathrm{E}-01$ & $(9.54 \mathrm{E}-01)$ & $(1.39 \mathrm{E}-01)$ & $1.36 \mathrm{E}+02$ \\
\hline B1KC37A & C5378 & 46.3 & $1.40 \mathrm{E}+00$ & $(1.76 \mathrm{E}+00)$ & $(6.20 \mathrm{E}-01)$ & $1.10 \mathrm{E}+02$ \\
\hline B1KC37B & C5378 & 45.8 & $5.96 \mathrm{E}-01$ & $(8.25 \mathrm{E}-01)$ & $(2.22 \mathrm{E}-01)$ & $5.48 \mathrm{E}+01$ \\
\hline $\mathrm{B} 1 \mathrm{KC} 37 \mathrm{C}$ & C5378 & 45.3 & $7.64 \mathrm{E}-01$ & $(7.07 \mathrm{E}-01)$ & $3.93 \mathrm{E}-01$ & $1.51 \mathrm{E}+01$ \\
\hline B1KC38A & C5378 & 63.3 & $6.28 \mathrm{E}-01$ & $(9.32 \mathrm{E}-01)$ & $(1.03 \mathrm{E}-01)$ & $1.60 \mathrm{E}+02$ \\
\hline B1KC38B & C5378 & 62.8 & $5.48 \mathrm{E}-01$ & $(7.96 \mathrm{E}-01)$ & $(9.40 \mathrm{E}-02)$ & $1.67 \mathrm{E}+02$ \\
\hline $\mathrm{B} 1 \mathrm{KC} 38 \mathrm{C}$ & C5378 & 62.3 & $8.32 \mathrm{E}-01$ & $(9.10 \mathrm{E}-01)$ & $(1.30 \mathrm{E}-01)$ & $1.70 \mathrm{E}+02$ \\
\hline B1KC39A & C5384 & 45.3 & $2.83 \mathrm{E}+00$ & $(2.08 \mathrm{E}+00)$ & $1.16 \mathrm{E}+00$ & $3.88 \mathrm{E}+01$ \\
\hline B1KC39B & C5384 & 44.8 & $2.48 \mathrm{E}+00$ & $(1.66 \mathrm{E}+00)$ & $1.02 \mathrm{E}+00$ & $3.16 \mathrm{E}+01$ \\
\hline B1KC39C & C5384 & 44.3 & $3.03 \mathrm{E}+00$ & $(1.97 \mathrm{E}+00)$ & $1.31 \mathrm{E}+00$ & $2.91 \mathrm{E}+01$ \\
\hline B1KC40A & C5374 & 81.3 & $3.17 \mathrm{E}+01$ & $1.39 \mathrm{E}+00$ & $1.14 \mathrm{E}+01$ & $1.02 \mathrm{E}+01$ \\
\hline $\mathrm{B} 1 \mathrm{KC} 40 \mathrm{~B}$ & C5374 & 80.8 & $2.52 \mathrm{E}+01$ & $1.18 \mathrm{E}+00$ & $9.19 \mathrm{E}+00$ & $7.68 \mathrm{E}+00$ \\
\hline $\mathrm{B} 1 \mathrm{KC} 40 \mathrm{C}$ & C5374 & 80.3 & $3.54 \mathrm{E}+01$ & $1.92 \mathrm{E}+00$ & $1.40 \mathrm{E}+01$ & $7.79 \mathrm{E}+00$ \\
\hline B1LB07A & C5382 & 79.3 & $3.32 \mathrm{E}+00$ & $(5.71 \mathrm{E}-01)$ & $1.21 \mathrm{E}+00$ & $5.74 \mathrm{E}+00$ \\
\hline B1LB07B & C5382 & 78.8 & $3.68 \mathrm{E}+00$ & $(7.56 \mathrm{E}-01)$ & $1.30 \mathrm{E}+00$ & $8.58 \mathrm{E}+00$ \\
\hline B1LB07C & C5382 & 78.3 & $6.31 \mathrm{E}+00$ & $(1.68 \mathrm{E}+00)$ & $2.31 \mathrm{E}+00$ & $1.97 \mathrm{E}+01$ \\
\hline B1LB08A & C5380 & 51.3 & $5.88 \mathrm{E}-01$ & $(1.24 \mathrm{E}+00)$ & $(1.71 \mathrm{E}-01)$ & $3.18 \mathrm{E}+01$ \\
\hline B1LB08B & C5380 & 50.8 & $5.04 \mathrm{E}-01$ & $(1.33 \mathrm{E}+00)$ & $(1.47 \mathrm{E}-01)$ & $2.93 \mathrm{E}+01$ \\
\hline B1LB08C & C5380 & 50.3 & $6.49 \mathrm{E}-01$ & $(1.37 \mathrm{E}+00)$ & $(2.48 \mathrm{E}-01)$ & $3.34 \mathrm{E}+01$ \\
\hline
\end{tabular}


Table 4.24. Calculated Pore Water Mobile Metal Concentrations of Key Contaminants of Concern in the T Tank Farm Direct Push Core and Grab Samples

\begin{tabular}{|c|c|c|c|c|c|c|}
\hline $\begin{array}{l}\text { Sample } \\
\text { ID }\end{array}$ & $\begin{array}{c}\text { Probe Hole } \\
\text { ID }\end{array}$ & $\begin{array}{l}\text { Mid-Depth } \\
\text { ft bgs }\end{array}$ & $\begin{array}{c}\text { Technetium-99 } \\
\text { pCi/L }\end{array}$ & $\begin{array}{c}\text { Uranium-238 } \\
\mu \mathrm{g} / \mathrm{L}\end{array}$ & $\begin{array}{c}\text { Chromium-52 } \\
\mu \mathrm{g} / \mathrm{L}\end{array}$ & $\begin{array}{c}\text { Molybdenum-95 } \\
\mu \mathrm{g} / \mathrm{L}\end{array}$ \\
\hline B1KC35A & C4598 & 43.8 & $3.22 \mathrm{E}+04$ & $2.77 \mathrm{E}+03$ & $2.93 \mathrm{E}+02$ & $7.69 \mathrm{E}+02$ \\
\hline B1KC35B & C4598 & 43.3 & $4.08 E+04$ & $3.26 \mathrm{E}+03$ & $1.51 \mathrm{E}+02$ & $5.15 \mathrm{E}+03$ \\
\hline B1KC36A & C4596 & 48.3 & $7.64 \mathrm{E}+03$ & $4.76 \mathrm{E}+02$ & $5.72 \mathrm{E}+02$ & $1.07 \mathrm{E}+03$ \\
\hline B1KC36B & C4596 & 47.8 & $7.02 E+03$ & $3.87 \mathrm{E}+02$ & $8.24 \mathrm{E}+02$ & $8.18 \mathrm{E}+02$ \\
\hline $\mathrm{B} 1 \mathrm{KC} 36 \mathrm{C}$ & C4596 & 47.3 & $1.30 \mathrm{E}+04$ & $3.64 \mathrm{E}+02$ & $1.80 \mathrm{E}+02$ & $6.83 \mathrm{E}+02$ \\
\hline B1KC37A & C5378 & 46.3 & $3.82 \mathrm{E}+03$ & $6.99 \mathrm{E}+02$ & $3.05 \mathrm{E}+02$ & $9.69 \mathrm{E}+02$ \\
\hline B1KC37B & C5378 & 45.8 & $2.02 E+03$ & $3.28 \mathrm{E}+02$ & $2.47 \mathrm{E}+02$ & $4.82 \mathrm{E}+02$ \\
\hline B1KC37C & C5378 & 45.3 & $4.69 \mathrm{E}+02$ & $2.33 \mathrm{E}+01$ & $1.76 \mathrm{E}+02$ & $6.58 \mathrm{E}+02$ \\
\hline B1KC38A & C5378 & 63.3 & $4.36 \mathrm{E}+04$ & $2.06 \mathrm{E}+03$ & $1.19 \mathrm{E}+03$ & $3.84 \mathrm{E}+02$ \\
\hline B1KC38B & C5378 & 62.8 & $2.69 \mathrm{E}+04$ & $2.24 \mathrm{E}+03$ & $1.44 \mathrm{E}+03$ & $5.85 \mathrm{E}+02$ \\
\hline B1KC38C & C5378 & 62.3 & $2.17 E+04$ & $2.82 \mathrm{E}+03$ & $1.27 \mathrm{E}+03$ & $1.45 \mathrm{E}+03$ \\
\hline B1KC39A & C5384 & 45.3 & $<9.62 \mathrm{E}+02$ & $5.81 \mathrm{E}+01$ & $(4.37 \mathrm{E}+01)$ & $6.08 \mathrm{E}+02$ \\
\hline B1KC39B & C5384 & 44.8 & $<7.63 \mathrm{E}+02$ & $5.44 \mathrm{E}+01$ & $(2.77 \mathrm{E}+01)$ & $5.36 \mathrm{E}+02$ \\
\hline B1KC39C & C5384 & 44.3 & $(3.34 \mathrm{E}+02)$ & $3.47 \mathrm{E}+01$ & $(2.31 \mathrm{E}+01)$ & $2.74 \mathrm{E}+03$ \\
\hline B1KC40A & C5374 & 81.3 & $4.77 E+05$ & $1.26 \mathrm{E}+01$ & $2.34 \mathrm{E}+04$ & $1.08 \mathrm{E}+02$ \\
\hline $\mathrm{B} 1 \mathrm{KC} 40 \mathrm{~B}$ & C5374 & 80.8 & $4.36 \mathrm{E}+05$ & $1.02 \mathrm{E}+01$ & $2.16 \mathrm{E}+04$ & $8.35 \mathrm{E}+01$ \\
\hline $\mathrm{B} 1 \mathrm{KC} 40 \mathrm{C}$ & C5374 & 80.3 & $1.17 \mathrm{E}+05$ & $1.11 \mathrm{E}+01$ & $6.45 \mathrm{E}+02$ & $4.66 \mathrm{E}+02$ \\
\hline B1LB07A & C5382 & 79.3 & $4.96 \mathrm{E}+02$ & $1.63 \mathrm{E}+01$ & $(1.77 \mathrm{E}+01)$ & $3.22 \mathrm{E}+02$ \\
\hline B1LB07B & C5382 & 78.8 & $1.89 \mathrm{E}+02$ & $2.33 \mathrm{E}+01$ & $(2.07 \mathrm{E}+01)$ & $5.79 \mathrm{E}+02$ \\
\hline B1LB07C & C5382 & 78.3 & $<5.70 \mathrm{E}+02$ & $3.92 \mathrm{E}+01$ & $(1.10 \mathrm{E}+01)$ & $1.10 \mathrm{E}+03$ \\
\hline B1LB08A & C5380 & 51.3 & $(2.10 \mathrm{E}+02)$ & $1.50 \mathrm{E}+02$ & $(2.05 \mathrm{E}+01)$ & $8.77 \mathrm{E}+02$ \\
\hline B1LB08B & C5380 & 50.8 & $3.11 \mathrm{E}+02$ & $1.84 \mathrm{E}+02$ & $(2.79 \mathrm{E}+01)$ & $8.86 \mathrm{E}+02$ \\
\hline B1LB08C & C5380 & 50.3 & $7.95 \mathrm{E}+02$ & $1.61 \mathrm{E}+02$ & $(2.68 \mathrm{E}+01)$ & $1.31 \mathrm{E}+03$ \\
\hline
\end{tabular}




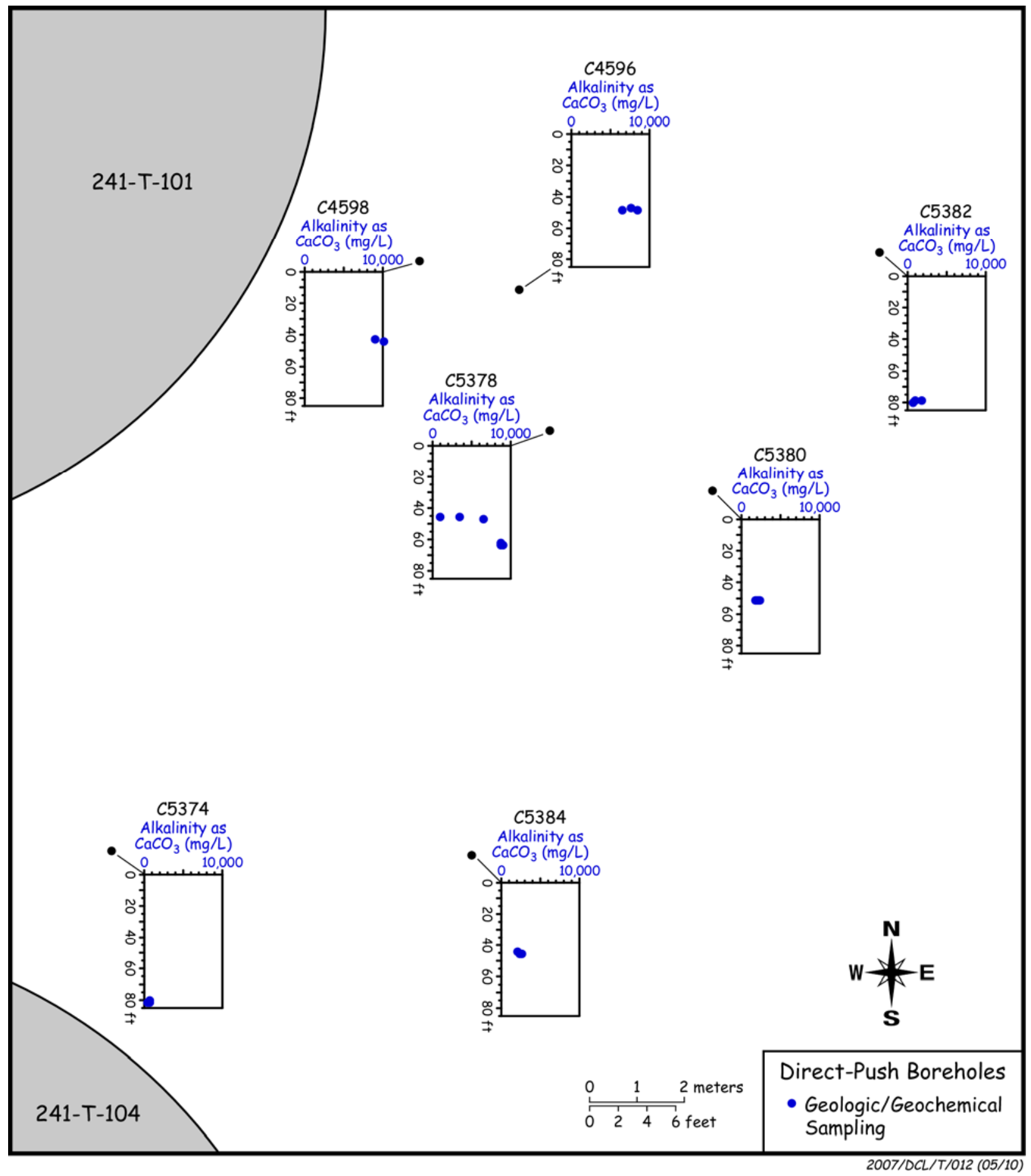

Figure 4.16. 1:1 Sediment:Water-Extractable Alkalinity Data from the T Tank Farm Direct Push Samples 


\subsubsection{M Nitric Acid-Extractable Amounts of Selected Elements in the T Tank Farm Direct Push Sediments}

The same cores and grab samples that were characterized for water-leachable constituents were also characterized to see how much of the various constituents could be extracted with hot $8 \mathrm{M}$ nitric acid. A comparison between the quantities that were acid extractable with those that are water-extractable often indicates the relative mobility of a given constituent and can sometimes differentiate man-disposed from naturally occurring constituents. The acid extractable concentrations are shown in Tables 4.25 through Table 4.27. For a majority of the constituents, there were no significantly elevated acid-extractable values from the T Tank Farm direct push sediments with the exception of technetium-99 and possibly small amounts of uranium-238 in a few of the samples. Quantifiable concentrations of acid extractable technetium-99 were detected in probe holes C4598, C4596, C5378, and C5374. Furthermore, when these concentrations were compared to the water-extractable technetium-99 concentrations, it was found that in most cases the amount of technetium-99 that was acid extractable was significantly higher. The difference in measured technetium-99 values between the acid leaches and water extracts ranged from a low of $124 \%$ for sample B1KC40A (probe hole C5374) to a high of 2,700\% for sample B1KC36A (probe hole C4596). In previous borehole reports, the acid-leachable technetium-99 has been considered to be less valid than the water-extractable technetium-99 data, and as such, has been reported as qualitative. However, this trend, in which acid-leachable concentrations of technetium-99 are significantly higher than water-extractable technetium-99 concentrations from separate aliquots from the same homogenized sample, has occurred in many of the contaminated boreholes measured as part of the Single Shell Tank Vadose Zone Project, as well as in many of the residual tank sludge samples analyzed as part of the Geochemical Testing and Residual Tank Waste Model Development Project. A current hypothesis is that some of the technetium-99 is being sequestered with iron oxides that result from the interaction of caustic tank waste with the vadose zone sediment or tank sludge. From a long-term risk standpoint, it is imperative to quantify the total concentration of technetium-99 present in these samples; therefore, additional analyses were preformed (presented in Section 4.3) in order to determine if these elevated values of technetium-99 were real, or just artifacts of analysis.

Three of the acid extracts contained approximately $2 \mu \mathrm{g} / \mathrm{g}$ uranium-238. The three sediments were collected from probe holes C4598 and C5378, respectively. Although Hanford sediment contains $3-5 \mu \mathrm{g} / \mathrm{g}$ natural uranium, it is doubtful the uanium-238 measured in these three samples was solely natural uranium. Natural uranium minerals present in Hanford sediments are very recalcitrant to leaching; generally less than $5 \%$ of the uranium present in the minerals can be leached using $8 \mathrm{M}$ nitric acid. Therefore, it appears that trace amounts of process uranium are present in a few of the direct push sediment samples collected near tank 241-T-101. 
Table 4.25. Acid-Extractable Cations in the T Tank Farm Direct Push Core and Grab Samples ( $\mu \mathrm{g} / \mathrm{g}$ dry sediment)

\begin{tabular}{||l|c|c|c|c|c|c||}
\hline $\begin{array}{c}\text { Sample } \\
\text { ID }\end{array}$ & $\begin{array}{c}\text { Probe Hole } \\
\text { ID }\end{array}$ & $\begin{array}{c}\text { Mid-Depth } \\
\mathrm{ft} \text { bgs }\end{array}$ & $\begin{array}{c}\text { Calcium } \\
\mu \mathrm{g} / \mathrm{g}\end{array}$ & $\begin{array}{c}\text { Potassium } \\
\mu \mathrm{g} / \mathrm{g}\end{array}$ & $\begin{array}{c}\text { Magnesium } \\
\mu \mathrm{g} / \mathrm{g}\end{array}$ & $\begin{array}{c}\text { Strontium } \\
\mu \mathrm{g} / \mathrm{g}\end{array}$ \\
\hline \hline B1KC35A & C4598 & 43.8 & $8.56 \mathrm{E}+03$ & $1.10 \mathrm{E}+03$ & $5.42 \mathrm{E}+03$ & $3.62 \mathrm{E}+01$ \\
\hline B1KC35B & C4598 & 43.3 & $9.08 \mathrm{E}+03$ & $1.21 \mathrm{E}+03$ & $5.38 \mathrm{E}+03$ & $4.14 \mathrm{E}+01$ \\
\hline B1KC36A & C4596 & 48.3 & $9.10 \mathrm{E}+03$ & $1.23 \mathrm{E}+03$ & $6.14 \mathrm{E}+03$ & $4.10 \mathrm{E}+01$ \\
\hline B1KC36B & C4596 & 47.8 & $8.16 \mathrm{E}+03$ & $1.01 \mathrm{E}+03$ & $5.55 \mathrm{E}+03$ & $3.45 \mathrm{E}+01$ \\
\hline B1KC36C & C4596 & 47.3 & $7.66 \mathrm{E}+03$ & $9.79 \mathrm{E}+02$ & $5.41 \mathrm{E}+03$ & $3.56 \mathrm{E}+01$ \\
\hline B1KC37A & C5378 & 46.3 & $8.32 \mathrm{E}+03$ & $8.23 \mathrm{E}+02$ & $4.91 \mathrm{E}+03$ & $3.38 \mathrm{E}+01$ \\
\hline B1KC37B & C5378 & 45.8 & $7.62 \mathrm{E}+03$ & $9.14 \mathrm{E}+02$ & $5.19 \mathrm{E}+03$ & $3.43 \mathrm{E}+01$ \\
\hline B1KC37C & C5378 & 45.3 & $1.07 \mathrm{E}+04$ & $1.81 \mathrm{E}+03$ & $6.79 \mathrm{E}+03$ & $4.34 \mathrm{E}+01$ \\
\hline B1KC38A & C5378 & 63.3 & $9.62 \mathrm{E}+03$ & $7.04 \mathrm{E}+02$ & $4.85 \mathrm{E}+03$ & $3.44 \mathrm{E}+01$ \\
\hline B1KC38B & C5378 & 62.8 & $1.04 \mathrm{E}+04$ & $6.67 \mathrm{E}+02$ & $4.71 \mathrm{E}+03$ & $3.50 \mathrm{E}+01$ \\
\hline B1KC38C & C5378 & 62.3 & $1.06 \mathrm{E}+04$ & $6.47 \mathrm{E}+02$ & $4.40 \mathrm{E}+03$ & $4.21 \mathrm{E}+01$ \\
\hline B1KC39A & C5384 & 45.3 & $8.55 \mathrm{E}+03$ & $9.50 \mathrm{E}+02$ & $5.45 \mathrm{E}+03$ & $3.68 \mathrm{E}+01$ \\
\hline B1KC39B & C5384 & 44.8 & $8.58 \mathrm{E}+03$ & $9.83 \mathrm{E}+02$ & $5.18 \mathrm{E}+03$ & $3.47 \mathrm{E}+01$ \\
\hline B1KC39C & C5384 & 44.3 & $9.10 \mathrm{E}+03$ & $9.62 \mathrm{E}+02$ & $5.71 \mathrm{E}+03$ & $4.00 \mathrm{E}+01$ \\
\hline B1KC40A & C5374 & 81.3 & $1.41 \mathrm{E}+04$ & $2.03 \mathrm{E}+03$ & $8.91 \mathrm{E}+03$ & $5.07 \mathrm{E}+01$ \\
\hline B1KC40B & C5374 & 80.8 & $1.29 \mathrm{E}+04$ & $1.62 \mathrm{E}+03$ & $7.84 \mathrm{E}+03$ & $4.66 \mathrm{E}+01$ \\
\hline B1KC40C & C5374 & 80.3 & $1.33 \mathrm{E}+04$ & $1.56 \mathrm{E}+03$ & $7.51 \mathrm{E}+03$ & $4.89 \mathrm{E}+01$ \\
\hline B1LB07A & C5382 & 79.3 & $1.48 \mathrm{E}+04$ & $1.70 \mathrm{E}+03$ & $7.75 \mathrm{E}+03$ & $4.65 \mathrm{E}+01$ \\
\hline B1LB07B & C5382 & 78.8 & $2.23 \mathrm{E}+04$ & $1.59 \mathrm{E}+03$ & $7.90 \mathrm{E}+03$ & $6.12 \mathrm{E}+01$ \\
\hline B1LB07C & C5382 & 78.3 & $1.37 \mathrm{E}+04$ & $7.51 \mathrm{E}+02$ & $5.31 \mathrm{E}+03$ & $4.37 \mathrm{E}+01$ \\
\hline B1LB08A & C5380 & 51.3 & $9.58 \mathrm{E}+03$ & $1.04 \mathrm{E}+03$ & $5.51 \mathrm{E}+03$ & $3.57 \mathrm{E}+01$ \\
\hline B1LB08B & C5380 & 50.8 & $8.64 \mathrm{E}+03$ & $1.03 \mathrm{E}+03$ & $5.50 \mathrm{E}+03$ & $3.41 \mathrm{E}+01$ \\
\hline B1LB08C & C5380 & 50.3 & $8.15 \mathrm{E}+03$ & $1.08 \mathrm{E}+03$ & $5.25 \mathrm{E}+03$ & $3.01 \mathrm{E}+01$ \\
\hline \hline
\end{tabular}


Table 4.26. Acid-Leachable Cations in the T Tank Farm Core Samples ( $\mu \mathrm{g} / \mathrm{g}$ dry sediment)

\begin{tabular}{||l|c|c|c|c|c|c||}
\hline $\begin{array}{c}\text { Sample } \\
\text { ID }\end{array}$ & $\begin{array}{c}\text { Probe Hole } \\
\text { ID }\end{array}$ & $\begin{array}{c}\text { Mid-Depth } \\
f t \text { bgs }\end{array}$ & $\begin{array}{c}\text { Aluminum } \\
\mu \mathrm{g} / \mathrm{g}\end{array}$ & $\begin{array}{c}\text { Iron } \\
\mu \mathrm{g} / \mathrm{g}\end{array}$ & $\begin{array}{c}\text { Phosphorus } \\
\mu \mathrm{g} / \mathrm{g}\end{array}$ & $\begin{array}{c}\text { Chromium } \\
\mu \mathrm{g} / \mathrm{g}\end{array}$ \\
\hline \hline B1KC35A & C4598 & 43.8 & $9.56 \mathrm{E}+03$ & $2.03 \mathrm{E}+04$ & $6.53 \mathrm{E}+02$ & $2.23 \mathrm{E}+01$ \\
\hline B1KC35B & C4598 & 43.3 & $9.46 \mathrm{E}+03$ & $2.57 \mathrm{E}+04$ & $7.73 \mathrm{E}+02$ & $7.68 \mathrm{E}+01$ \\
\hline B1KC36A & C4596 & 48.3 & $9.54 \mathrm{E}+03$ & $1.85 \mathrm{E}+04$ & $6.38 \mathrm{E}+02$ & $2.14 \mathrm{E}+01$ \\
\hline B1KC36B & C4596 & 47.8 & $7.97 \mathrm{E}+03$ & $1.72 \mathrm{E}+04$ & $5.33 \mathrm{E}+02$ & $2.29 \mathrm{E}+01$ \\
\hline B1KC36C & C4596 & 47.3 & $8.18 \mathrm{E}+03$ & $1.84 \mathrm{E}+04$ & $5.91 \mathrm{E}+02$ & $2.58 \mathrm{E}+01$ \\
\hline B1KC37A & C5378 & 46.3 & $7.08 \mathrm{E}+03$ & $1.69 \mathrm{E}+04$ & $5.96 \mathrm{E}+02$ & $1.20 \mathrm{E}+01$ \\
\hline B1KC37B & C5378 & 45.8 & $7.72 \mathrm{E}+03$ & $1.88 \mathrm{E}+04$ & $6.73 \mathrm{E}+02$ & $1.41 \mathrm{E}+01$ \\
\hline B1KC37C & C5378 & 45.3 & $1.10 \mathrm{E}+04$ & $2.09 \mathrm{E}+04$ & $5.71 \mathrm{E}+02$ & $2.97 \mathrm{E}+01$ \\
\hline B1KC38A & C5378 & 63.3 & $7.87 \mathrm{E}+03$ & $2.14 \mathrm{E}+04$ & $8.31 \mathrm{E}+02$ & $1.85 \mathrm{E}+01$ \\
\hline B1KC38B & C5378 & 62.8 & $7.38 \mathrm{E}+03$ & $2.24 \mathrm{E}+04$ & $9.59 \mathrm{E}+02$ & $1.70 \mathrm{E}+01$ \\
\hline B1KC38C & C5378 & 62.3 & $7.37 \mathrm{E}+03$ & $1.98 \mathrm{E}+04$ & $8.89 \mathrm{E}+02$ & $2.00 \mathrm{E}+01$ \\
\hline B1KC39A & C5384 & 45.3 & $7.58 \mathrm{E}+03$ & $1.72 \mathrm{E}+04$ & $6.02 \mathrm{E}+02$ & $1.68 \mathrm{E}+01$ \\
\hline B1KC39B & C5384 & 44.8 & $7.39 \mathrm{E}+03$ & $1.71 \mathrm{E}+04$ & $5.81 \mathrm{E}+02$ & $1.54 \mathrm{E}+01$ \\
\hline B1KC39C & C5384 & 44.3 & $8.97 \mathrm{E}+03$ & $2.05 \mathrm{E}+04$ & $6.89 \mathrm{E}+02$ & $2.34 \mathrm{E}+01$ \\
\hline B1KC40A & C5374 & 81.3 & $1.87 \mathrm{E}+04$ & $2.41 \mathrm{E}+04$ & $6.64 \mathrm{E}+02$ & $3.02 \mathrm{E}+01$ \\
\hline B1KC40B & C5374 & 80.8 & $1.24 \mathrm{E}+04$ & $1.93 \mathrm{E}+04$ & $7.78 \mathrm{E}+02$ & $3.27 \mathrm{E}+01$ \\
\hline B1KC40C & C5374 & 80.3 & $1.16 \mathrm{E}+04$ & $1.85 \mathrm{E}+04$ & $8.45 \mathrm{E}+02$ & $4.33 \mathrm{E}+01$ \\
\hline B1LB07A & C5382 & 79.3 & $1.18 \mathrm{E}+04$ & $1.91 \mathrm{E}+04$ & $6.90 \mathrm{E}+02$ & $2.04 \mathrm{E}+01$ \\
\hline B1LB07B & C5382 & 78.8 & $1.23 \mathrm{E}+04$ & $2.06 \mathrm{E}+04$ & $6.97 \mathrm{E}+02$ & $2.59 \mathrm{E}+01$ \\
\hline B1LB07C & C5382 & 78.3 & $7.38 \mathrm{E}+03$ & $1.96 \mathrm{E}+04$ & $7.31 \mathrm{E}+02$ & $1.58 \mathrm{E}+01$ \\
\hline B1LB08A & C5380 & 51.3 & $8.70 \mathrm{E}+03$ & $2.21 \mathrm{E}+04$ & $8.56 \mathrm{E}+02$ & $2.92 \mathrm{E}+01$ \\
\hline B1LB08B & C5380 & 50.8 & $7.88 \mathrm{E}+03$ & $1.80 \mathrm{E}+04$ & $6.05 \mathrm{E}+02$ & $2.90 \mathrm{E}+01$ \\
\hline B1LB08C & C5380 & 50.3 & $7.10 \mathrm{E}+03$ & $1.60 \mathrm{E}+04$ & $5.78 \mathrm{E}+02$ & $3.05 \mathrm{E}+01$ \\
\hline Indicates the information was not determined for the sample. & & & \\
\hline
\end{tabular}


Table 4.27. Acid-Extractable Mobile Metals in the T Tank Farm Direct Push Core and Grab Samples $(\mu \mathrm{g} / \mathrm{g}$ dry sediment)

\begin{tabular}{|c|c|c|c|c|c|c|c|}
\hline $\begin{array}{l}\text { Sample } \\
\text { ID }\end{array}$ & $\begin{array}{l}\text { Probe } \\
\text { Hole } \\
\text { ID }\end{array}$ & $\begin{array}{l}\text { Mid-Depth } \\
\mathrm{ft} \text { bgs }\end{array}$ & $\begin{array}{c}\text { Technetium- } \\
99 \\
\text { pCi/g } \\
\end{array}$ & $\begin{array}{c}\text { Uranium- } \\
238 \\
\mu \mathrm{g} / \mathrm{g}\end{array}$ & $\begin{array}{c}\text { Molybdenum- } \\
95 \\
\mu \mathrm{g} / \mathrm{g} \\
\end{array}$ & $\begin{array}{c}\text { Ruthenium- } \\
101 \\
\mu \mathrm{g} / \mathrm{g}\end{array}$ & $\begin{array}{c}\text { Ruthenium- } \\
102 \\
\mu \mathrm{g} / \mathrm{g}\end{array}$ \\
\hline B1KC35A & $\begin{array}{c}\mathrm{C} 4598 \\
\end{array}$ & 43.8 & $1.56 \mathrm{E}+01$ & $2.52 \mathrm{E}+00$ & $7.85 \mathrm{E}-01$ & (1.03E-02) & 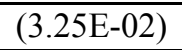 \\
\hline $\mathrm{B} 1 \mathrm{KC} 35 \mathrm{~B}$ & C4598 & 43.3 & $1.47 E+01$ & $2.07 \mathrm{E}+00$ & $8.94 \mathrm{E}+00$ & $(1.29 \mathrm{E}-02)$ & (3.59E-02) \\
\hline B1KC36A & C4596 & 48.3 & $1.32 \mathrm{E}+01$ & $7.67 \mathrm{E}-01$ & $3.59 \mathrm{E}-01$ & $(2.45 \mathrm{E}-02)$ & $(4.15 \mathrm{E}-02)$ \\
\hline B1KC36B & C4596 & 47.8 & $(6.93 \mathrm{E}+00)$ & $5.38 \mathrm{E}-01$ & $4.12 \mathrm{E}-01$ & (7.19E-03) & (3.29E-02) \\
\hline $\mathrm{B} 1 \mathrm{KC} 36 \mathrm{C}$ & C4596 & 47.3 & $(5.38 \mathrm{E}+00)$ & $5.58 \mathrm{E}-01$ & $4.80 \mathrm{E}-01$ & $(1.61 \mathrm{E}-02)$ & $(3.46 \mathrm{E}-02)$ \\
\hline B1KC37A & C5378 & 46.3 & $(2.64 \mathrm{E}+00)$ & $5.22 \mathrm{E}-01$ & $3.36 \mathrm{E}-01$ & $(5.47 \mathrm{E}-03)$ & $(3.28 \mathrm{E}-02)$ \\
\hline B1KC37B & C5378 & 45.8 & $(3.15 \mathrm{E}+00)$ & $6.71 \mathrm{E}-01$ & $3.77 \mathrm{E}-01$ & $(1.26 \mathrm{E}-02)$ & (3.47E-02) \\
\hline B1KC37C & C5378 & 45.3 & $(6.59 \mathrm{E}+00)$ & $2.06 \mathrm{E}+00$ & $9.06 \mathrm{E}-01$ & $(3.48 \mathrm{E}-02)$ & $(5.21 \mathrm{E}-02)$ \\
\hline B1KC38A & C5378 & 63.3 & $(5.80 \mathrm{E}+00)$ & $5.85 \mathrm{E}-01$ & $3.94 \mathrm{E}-01$ & $(6.77 \mathrm{E}-03)$ & (3.40E-02) \\
\hline B1KC38B & C5378 & 62.8 & $(4.45 \mathrm{E}+00)$ & $6.22 \mathrm{E}-01$ & $3.66 \mathrm{E}-01$ & $(7.88 \mathrm{E}-03)$ & (3.14E-02) \\
\hline $\mathrm{B} 1 \mathrm{KC} 38 \mathrm{C}$ & C5378 & 62.3 & $8.30 \mathrm{E}+00$ & $8.53 \mathrm{E}-01$ & $5.57 \mathrm{E}-01$ & $(2.15 \mathrm{E}-02)$ & $(4.35 \mathrm{E}-02)$ \\
\hline B1KC39A & C5384 & 45.3 & $(8.66 \mathrm{E}-01)$ & $4.61 \mathrm{E}-01$ & $2.91 \mathrm{E}-01$ & $<<5.06 \mathrm{E}-02$ & (2.99E-02) \\
\hline B1KC39B & C5384 & 44.8 & $<1.04 \mathrm{E}+01$ & 4.42E-01 & $(2.98 \mathrm{E}-01)$ & $(9.82 \mathrm{E}-04)$ & $(2.88 \mathrm{E}-02)$ \\
\hline B1KC39C & C5384 & 44.3 & $(5.31 \mathrm{E}-01)$ & $4.63 \mathrm{E}-01$ & $7.55 \mathrm{E}-01$ & $<4.97 \mathrm{E}-02$ & $(2.90 \mathrm{E}-02)$ \\
\hline B1KC40A & C5374 & 81.3 & $9.77 E+01$ & $8.80 \mathrm{E}-01$ & $3.07 \mathrm{E}-01$ & $(1.48 \mathrm{E}-02)$ & (5.07E-02) \\
\hline B1KC40B & C5374 & 80.8 & $1.00 \mathrm{E}+02$ & $6.97 \mathrm{E}-01$ & $3.59 \mathrm{E}-01$ & $(1.61 \mathrm{E}-02)$ & (4.32E-02) \\
\hline $\mathrm{B} 1 \mathrm{KC} 40 \mathrm{C}$ & C5374 & 80.3 & $1.34 \mathrm{E}+02$ & 7.89E-01 & $6.83 \mathrm{E}-01$ & $(2.77 \mathrm{E}-02)$ & (5.38E-02) \\
\hline B1LB07A & C5382 & 79.3 & $(2.70 \mathrm{E}+00)$ & $6.43 \mathrm{E}-01$ & $3.56 \mathrm{E}-01$ & $(9.71 \mathrm{E}-04)$ & $(4.28 \mathrm{E}-02)$ \\
\hline B1LB07B & C5382 & 78.8 & $(8.63 \mathrm{E}-01)$ & 6.90E-01 & $5.08 \mathrm{E}-01$ & (5.19E-05) & (5.29E-02) \\
\hline B1LB07C & C5382 & 78.3 & $(8.00 \mathrm{E}-01)$ & $4.45 \mathrm{E}-01$ & $7.56 \mathrm{E}-01$ & $<5.49 \mathrm{E}-02$ & $(3.27 \mathrm{E}-02)$ \\
\hline B1LB08A & C5380 & 51.3 & $(4.01 \mathrm{E}+00)$ & $6.02 \mathrm{E}-01$ & $5.35 \mathrm{E}-01$ & $(2.22 \mathrm{E}-02)$ & (3.43E-02) \\
\hline B1LB08B & C5380 & 50.8 & $(5.93 \mathrm{E}+00)$ & $7.65 \mathrm{E}-01$ & $5.31 \mathrm{E}-01$ & $(1.39 \mathrm{E}-02)$ & $(2.96 \mathrm{E}-02)$ \\
\hline B1LB08C & C5380 & 50.3 & $(8.83 \mathrm{E}+00)$ & $5.21 \mathrm{E}-01$ & $7.83 \mathrm{E}-01$ & $(1.75 \mathrm{E}-02)$ & (3.05E-02) \\
\hline
\end{tabular}

Comparison of the water to acid-extractable quantities of each constituent was performed by taking the data in Tables 4.19 through 4.21 and dividing them by the data in Tables 4.25 through 4.27. The data are not presented herein, but show that less than $0.1 \%$ of the acid-extractable quantities of the following elements were water leachable: aluminum, barium, cobalt, iron, manganese, titanium, and zirconium. Less than $1 \%$ of the acid-extractable quantities of the following elements were water leachable: calcium, copper, magnesium, nickel, phosphorous as phosphate, potassium, and zinc. Less than $5 \%$ of the acid-extractable molybdenum, silver, and strontium were water-extractable. Less than $10 \%$ of the acid-extractable chromium was water-extractable. Finally, less than $30 \%$ of the acid-extractable uranium was water-extractable. These results imply that some of the sediments collected as part of the T Tank Farm direct push campaign contain chromium and uranium contamination resulting from Hanford waste processes. These results imply that some of the sediments collected as part of the $\mathrm{T}$ farm direct push campaign contain chromium and uranium contamination resulting from Hanford waste processes. 


\subsubsection{Radionuclide Content in Vadose Zone Sediment from the TY Tank Farm Direct Push Holes}

Data from the gamma energy analysis of the samples are shown in Table 4.28 and Figures 4.17 and 4.18. The direct measurement of sediments for gamma-emitting radionuclides showed that the they contained natural potassium-40, the activation product cobalt-60, and the fission product isotopes cesium137, europium-152, europium-154, and europium-155. The samples that contained the man-made gamma-emitting radionuclides were from the four probe holes emplaced closest to tank 241-T-101. For comparison purposes, the highest europium-154 activity measured in these samples was $139 \mathrm{pCi} / \mathrm{g}$ vs. $2000 \mathrm{pCi} / \mathrm{g}$ at the 241-T-106 borehole (C4104) (Serne et al. 2004b). As much as $40 \mathrm{pCi} / \mathrm{g}$ cesium-137 was measured in borehole C4104 (Serne et al. 2004b), while the peak activity measured as part of this study was $16.8 \mathrm{pCi} / \mathrm{g}$. Given the mixed-depth sampling frequency that was performed during the direct push campaign, it is difficult to say anything about the relative mobility of the radionuclides; however, it appears that they may have migrated southeast from tank 241-T-101.

Table 4.28. Gamma-Emitting Radionuclides in the T Tank Farm Direct Push Sediments

\begin{tabular}{|c|c|c|c|c|c|c|c|c|}
\hline $\begin{array}{c}\text { Sample } \\
\text { ID }\end{array}$ & \begin{tabular}{|c|} 
Probe \\
Hole \\
ID \\
\end{tabular} & $\begin{array}{l}\text { Mid- } \\
\text { Depth } \\
\mathrm{ft} \text { bgs }\end{array}$ & $\begin{array}{c}\text { Potassium } \\
-40 \\
\mathrm{pCi} / \mathrm{g} \\
\end{array}$ & $\begin{array}{c}\text { Cobalt } \\
-60 \\
\mathrm{pCi} / \mathrm{g} \\
\end{array}$ & $\begin{array}{c}\text { Cesium } \\
-137 \\
\mathrm{pCi} / \mathrm{g} \\
\end{array}$ & \begin{tabular}{|c|} 
Europium- \\
152 \\
$\mathrm{pCi} / \mathrm{g}$ \\
\end{tabular} & \begin{tabular}{|c|} 
Europium- \\
154 \\
$\mathrm{pCi} / \mathrm{g}$ \\
\end{tabular} & \begin{tabular}{|c|} 
Europium- \\
155 \\
$\mathrm{pCi} / \mathrm{g}$ \\
\end{tabular} \\
\hline B1KC35A & C4598 & 43.8 & $1.55 \mathrm{E}+01$ & $5.49 \mathrm{E}+00$ & $<3.20 \mathrm{E}+00$ & $<2.97 \mathrm{E}+00$ & $9.41 \mathrm{E}+01$ & $9.21 \mathrm{E}+01$ \\
\hline B1KC35B & 4598 & 43.3 & $<1.08 \mathrm{E}+01$ & $<1.56 \mathrm{E}+00$ & $1.08 \mathrm{E}+01$ & $<4.59 \mathrm{E}+00$ & $8.41 \mathrm{E}+01$ & $7.32 \mathrm{E}+01$ \\
\hline B1KC36 & C4596 & 48.9 & $1.79 \mathrm{E}+01$ & $2.52 \mathrm{E}+00$ & $<1.45 \mathrm{E}+00$ & $<2.66 \mathrm{E}+00$ & $8.70 \mathrm{E}+01$ & $4.71 \mathrm{E}+01$ \\
\hline B1KC36A & C4596 & 48.3 & $1.68 \mathrm{E}+01$ & $2.71 \mathrm{E}+00$ & $6.37 \mathrm{E}+00$ & $<2.93 \mathrm{E}+00$ & $1.02 \mathrm{E}+02$ & $6.42 \mathrm{E}+01$ \\
\hline B1KC36B & 1596 & 47.8 & $<5.79 \mathrm{E}+00$ & & & $<2.27 \mathrm{E}+00$ & & \\
\hline B1KC36C & 596 & 47.3 & $1.57 \mathrm{E}+01$ & $1.26 \mathrm{E}+00$ & $<1.53 \mathrm{E}+00$ & $2.33 \mathrm{E}+00$ & $1.39 \mathrm{E}+02$ & $6.39 \mathrm{E}+01$ \\
\hline B1KC37A & 5378 & 46.3 & $1.93 \mathrm{E}+01$ & $<4.91 \mathrm{E}-01$ & \begin{tabular}{|c|}
$<45 \mathrm{E}-01$ \\
\end{tabular} & $<1.56 \mathrm{E}+00$ & $<9.25 \mathrm{E}-01$ & $<1.39 \mathrm{E}+00$ \\
\hline B1KC37B & C5378 & 45.8 & $<5.37 \mathrm{E}+00$ & $<<5.03 \mathrm{E}-01$ & $4.47 \mathrm{E}+00$ & $<1.84 \mathrm{E}+00$ & $4.27 \mathrm{E}+01$ & $\mathrm{E}+01$ \\
\hline B1KC37C & C5378 & 45.3 & $<6.27 \mathrm{E}+00$ & $<7.40 \mathrm{E}-01$ & $1.68 \mathrm{E}+01$ & $<2.56 \mathrm{E}+00$ & $9.11 \mathrm{E}+01$ & $\mathrm{E}+01$ \\
\hline B1KC38 & C5378 & 63.8 & $<6.86 \mathrm{E}+00$ & $<5.31 \mathrm{E}-01$ & \begin{tabular}{|c|} 
7.09E-01 \\
\end{tabular} & $<1.87 \mathrm{E}+00$ & $3.27 \mathrm{E}+01$ & $\mathrm{E}+01$ \\
\hline B1KC38A & C5378 & 63.3 & $<4.76 \mathrm{E}+00$ & $<4.28 \mathrm{E}-01$ & \begin{tabular}{|c|}
$<.32 \mathrm{E}-01$ \\
\end{tabular} & $<1.54 \mathrm{E}+00$ & $3.38 \mathrm{E}+01$ & $1.36 \mathrm{E}+01$ \\
\hline B1KC38B & C5378 & 62.8 & $1.27 \mathrm{E}+01$ & $8.66 \mathrm{E}-01$ & \begin{tabular}{|c|}
$<.96 \mathrm{E}-01$ \\
\end{tabular} & $<1.86 \mathrm{E}+00$ & $4.15 \mathrm{E}+01$ & $2.12 \mathrm{E}+01$ \\
\hline B1KC38C & C5378 & 62.3 & $<4.96 \mathrm{E}+00$ & $<7.70 \mathrm{E}-01$ & $<9.88 \mathrm{E}-01$ & $<2.49 \mathrm{E}+00$ & $1.33 \mathrm{E}+02$ & $5.80 \mathrm{E}+01$ \\
\hline B1KC39 & C5384 & 45.8 & $1.62 \mathrm{E}+01$ & $<2.16 \mathrm{E}-01$ & $<2.94 \mathrm{E}-01$ & $<1.08 \mathrm{E}+00$ & $<6.08 \mathrm{E}-01$ & $<1.03 \mathrm{E}+00$ \\
\hline B1KC39A & C5384 & 45.3 & $<4.95 \mathrm{E}+00$ & $<1.74 \mathrm{E}-01$ & \begin{tabular}{|c|}
$<24 \mathrm{E}-01$ \\
\end{tabular} & $<7.54 \mathrm{E}-01$ & $<4.58 \mathrm{E}-01$ & $<7.09 \mathrm{E}-01$ \\
\hline B1KC39B & C5384 & 44.8 & $1.78 \mathrm{E}+01$ & $<2.30 \mathrm{E}-01$ & $<2.68 \mathrm{E}-01$ & $<1.04 \mathrm{E}+00$ & $<5.87 \mathrm{E}-01$ & $<1.01 \mathrm{E}+00$ \\
\hline B1KC39C & C5384 & 44.3 & $<4.75 \mathrm{E}+00$ & $<1.69 \mathrm{E}-01$ & $<1.85 \mathrm{E}-01$ & $<6.55 \mathrm{E}-01$ & $<4.14 \mathrm{E}-01$ & $<6.51 \mathrm{E}-01$ \\
\hline B1KC40 & C5374 & 81.8 & $1.80 \mathrm{E}+01$ & $<3.13 \mathrm{E}-01$ & $<3.64 \mathrm{E}-01$ & $<1.42 \mathrm{E}+00$ & $<7.96 \mathrm{E}-01$ & $<1.34 \mathrm{E}+00$ \\
\hline B1KC40A & C5374 & 81.3 & $<5.90 \mathrm{E}+00$ & $<2.61 \mathrm{E}-01$ & \begin{tabular}{|c|}
$<2.73 \mathrm{E}-01$ \\
\end{tabular} & $<9.11 \mathrm{E}-01$ & $<$ <.44E-01 & $<9.19 \mathrm{E}-01$ \\
\hline B1KC40B & C5374 & 80.8 & $1.55 \mathrm{E}+01$ & $<2.78 \mathrm{E}-01$ & \begin{tabular}{|c|}
$<3.16 \mathrm{E}-01$ \\
\end{tabular} & $<1.30 \mathrm{E}+00$ & $<7.32 \mathrm{E}-01$ & $<1.29 \mathrm{E}+00$ \\
\hline B1KC40C & C5374 & 80.3 & $<5.68 \mathrm{E}+00$ & $<2.48 \mathrm{E}-01$ & \begin{tabular}{|c|}
$<2.65 \mathrm{E}-01$ \\
\end{tabular} & $<9.74 \mathrm{E}-01$ & $<<5.69 \mathrm{E}-01$ & $<9.52 \mathrm{E}-01$ \\
\hline & & & & $<2.5$ & $<3.2$ & $<1$. & $<7$ & $8+00$ \\
\hline B1LB07B & C5382 & 78.8 & $<5.74 \mathrm{E}+00$ & $<2.01 \mathrm{E}-01$ & $<2.66 \mathrm{E}-01$ & $<9.09 \mathrm{E}-01$ & $<5.64 \mathrm{E}-01$ & $<8.59 \mathrm{E}-01$ \\
\hline B1LB07C & C5382 & 78.3 & $1.36 \mathrm{E}+01$ & $<2.04 \mathrm{E}-01$ & \begin{tabular}{|c|}
$<2.60 \mathrm{E}-01$ \\
\end{tabular} & $<9.63 \mathrm{E}-01$ & $<5.43 \mathrm{E}-01$ & $<9.12 \mathrm{E}-01$ \\
\hline B1LB08 & C5380 & 51.8 & $1.37 \mathrm{E}+01$ & $1.33 \mathrm{E}+00$ & $<1.30 \mathrm{E}+00$ & $2.95 \mathrm{E}+00$ & $1.16 \mathrm{E}+02$ & $5.61 \mathrm{E}+01$ \\
\hline B1LB08A & C5380 & 51.3 & $<5.25 \mathrm{E}+00$ & $<5.74 \mathrm{E}-01$ & $1.30 \mathrm{E}+01$ & $<2.28 \mathrm{E}+00$ & $1.05 \mathrm{E}+02$ & $4.32 \mathrm{E}+01$ \\
\hline B1LB08B & C5380 & 50.8 & $<5.94 \mathrm{E}+00$ & $<6.11 \mathrm{E}-01$ & $1.98 \mathrm{E}+00$ & $<2.63 \mathrm{E}+00$ & $1.16 \mathrm{E}+02$ & $5.07 \mathrm{E}+01$ \\
\hline B1LB08C & C5380 & 50.3 & $1.73 \mathrm{E}+01$ & $1.44 \mathrm{E}+00$ & $<1.66 \mathrm{E}+00$ & $<2.87 \mathrm{E}+00$ & $1.15 \mathrm{E}+02$ & $6.19 \mathrm{E}+01$ \\
\hline
\end{tabular}




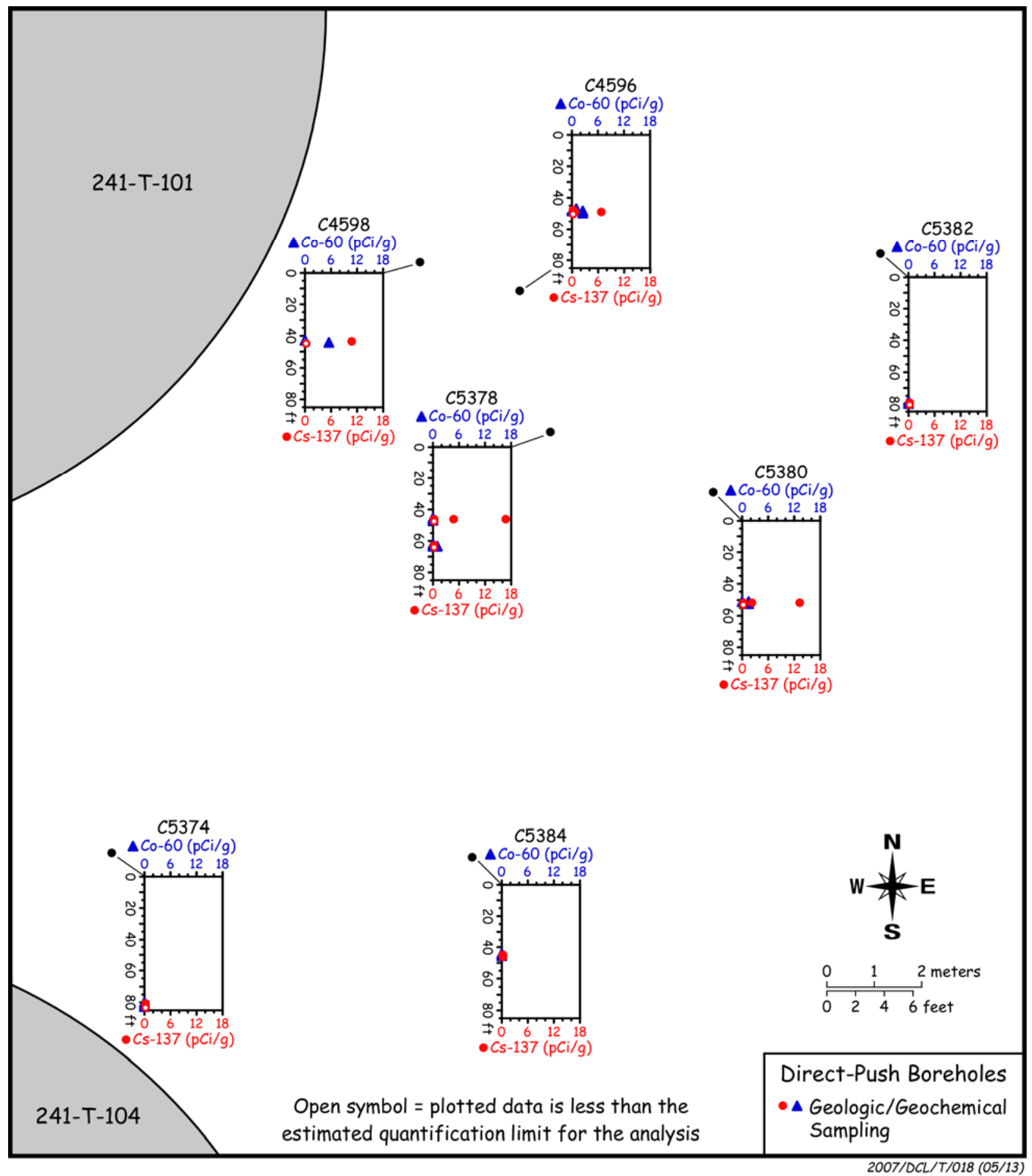

Figure 4.17. Gamma Energy Analysis Data (Cobalt-60 and Cesium-137) from the T Tank Farm Direct Push Samples 


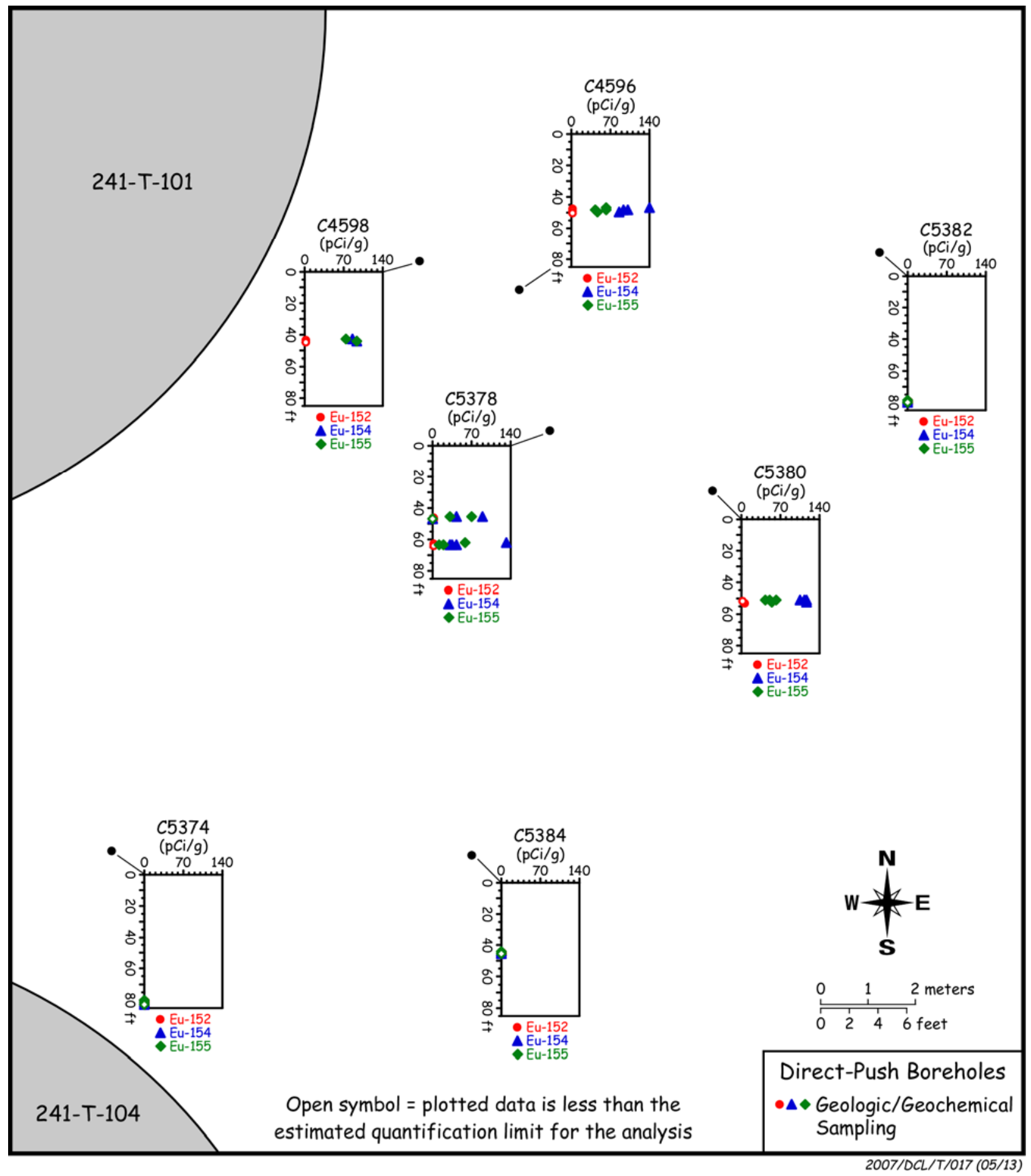

Figure 4.18. Gamma Energy Analysis Data (Europium Isotopes) from the T Tank Farm Direct Push Samples 


\subsubsection{Total Carbon, Calcium Carbonate, and Organic Carbon Content of Vadose Zone Sediment from the TY Tank Farm Direct Push Holes}

Data from the total carbon, inorganic carbon, and organic carbon (calculated by difference) contents of the T Tank Farm direct push sediments are shown in Table 4.29. The inorganic carbon was converted to the equivalent calcium carbonate content. In general, the sediments were low in organic carbon $\left(<0.15 \%\right.$ by weight), which is typical of Hanford Site sediments. Inorganic carbon, as $\mathrm{CaCO}_{3}$, was also present at concentrations that are typical for Hanford formation sediments $\left(0.5\right.$ to $3.34 \mathrm{wt} \%$ as $\left.\mathrm{CaCO}_{3}\right)$ and compare well with other samples from uncontaminated locations (Serne et al. 2004a,b).

Table 4.29. Carbon Content of the T Tank Farm Vadose Zone Samples

\begin{tabular}{|l|c|c|c|c|c|c||}
\hline $\begin{array}{c}\text { Sample } \\
\text { ID }\end{array}$ & $\begin{array}{c}\text { Probe Hole } \\
\text { ID }\end{array}$ & $\begin{array}{c}\text { Mid-Depth } \\
\text { ft bgs }\end{array}$ & $\begin{array}{c}\text { Total Carbon } \\
(\%)\end{array}$ & $\begin{array}{c}\text { Inorganic Carbon } \\
(\%)\end{array}$ & $\begin{array}{c}\text { Inorganic Carbon } \\
\text { as CaCO3 } \\
(\%)\end{array}$ & $\begin{array}{c}\text { Organic } \\
\text { Carbon } \\
(\%)\end{array}$ \\
\hline \hline B1KC35A & C4598 & 43.8 & $2.70 \mathrm{E}-01$ & $1.78 \mathrm{E}-01$ & $1.49 \mathrm{E}+00$ & $8.62 \mathrm{E}-02$ \\
\hline B1KC35B & C4598 & 43.3 & $2.58 \mathrm{E}-01$ & $1.44 \mathrm{E}-01$ & $1.20 \mathrm{E}+00$ & $1.14 \mathrm{E}-01$ \\
\hline B1KC36A & C4596 & 48.3 & $2.81 \mathrm{E}-01$ & $1.66 \mathrm{E}-01$ & $1.39 \mathrm{E}+00$ & $1.14 \mathrm{E}-01$ \\
\hline B1KC36B & C4596 & 47.8 & $2.42 \mathrm{E}-01$ & $1.51 \mathrm{E}-01$ & $1.26 \mathrm{E}+00$ & $9.17 \mathrm{E}-02$ \\
\hline B1KC36C & C4596 & 47.3 & $2.25 \mathrm{E}-01$ & $1.30 \mathrm{E}-01$ & $1.09 \mathrm{E}+00$ & $9.41 \mathrm{E}-02$ \\
\hline B1KC37A & C5378 & 46.3 & $2.70 \mathrm{E}-01$ & $1.97 \mathrm{E}-01$ & $1.65 \mathrm{E}+00$ & $7.24 \mathrm{E}-02$ \\
\hline B1KC37B & C5378 & 45.8 & $2.30 \mathrm{E}-01$ & $1.51 \mathrm{E}-01$ & $1.26 \mathrm{E}+00$ & $7.91 \mathrm{E}-02$ \\
\hline B1KC37C & C5378 & 45.3 & $3.06 \mathrm{E}-01$ & $2.40 \mathrm{E}-01$ & $2.00 \mathrm{E}+00$ & $6.63 \mathrm{E}-02$ \\
\hline B1KC38A & C5378 & 63.3 & $1.82 \mathrm{E}-01$ & $8.07 \mathrm{E}-02$ & $6.73 \mathrm{E}-01$ & $1.01 \mathrm{E}-01$ \\
\hline B1KC38B & C5378 & 62.8 & $2.49 \mathrm{E}-01$ & $1.71 \mathrm{E}-01$ & $1.43 \mathrm{E}+00$ & $7.78 \mathrm{E}-02$ \\
\hline B1KC38C & C5378 & 62.3 & $2.46 \mathrm{E}-01$ & $1.83 \mathrm{E}-01$ & $1.52 \mathrm{E}+00$ & $6.31 \mathrm{E}-02$ \\
\hline B1KC39A & C5384 & 45.3 & $3.15 \mathrm{E}-01$ & $2.42 \mathrm{E}-01$ & $2.01 \mathrm{E}+00$ & $7.30 \mathrm{E}-02$ \\
\hline B1KC39B & C5384 & 44.8 & $2.46 \mathrm{E}-01$ & $1.78 \mathrm{E}-01$ & $1.49 \mathrm{E}+00$ & $6.77 \mathrm{E}-02$ \\
\hline B1KC39C & C5384 & 44.3 & $2.69 \mathrm{E}-01$ & $1.88 \mathrm{E}-01$ & $1.56 \mathrm{E}+00$ & $8.13 \mathrm{E}-02$ \\
\hline B1KC40A & C5374 & 81.3 & $3.95 \mathrm{E}-01$ & $3.66 \mathrm{E}-01$ & $3.05 \mathrm{E}+00$ & $2.88 \mathrm{E}-02$ \\
\hline B1KC40B & C5374 & 80.8 & $3.86 \mathrm{E}-01$ & $3.40 \mathrm{E}-01$ & $2.83 \mathrm{E}+00$ & $4.65 \mathrm{E}-02$ \\
\hline B1KC40C & C5374 & 80.3 & $3.97 \mathrm{E}-01$ & $3.60 \mathrm{E}-01$ & $3.00 \mathrm{E}+00$ & $3.78 \mathrm{E}-02$ \\
\hline B1LB07A & C5382 & 79.3 & $4.47 \mathrm{E}-01$ & $4.01 \mathrm{E}-01$ & $3.34 \mathrm{E}+00$ & $4.63 \mathrm{E}-02$ \\
\hline B1LB07B & C5382 & 78.8 & $4.25 \mathrm{E}-01$ & $3.77 \mathrm{E}-01$ & $3.14 \mathrm{E}+00$ & $4.79 \mathrm{E}-02$ \\
\hline B1LB07C & C5382 & 78.3 & $2.51 \mathrm{E}-01$ & $2.15 \mathrm{E}-01$ & $1.79 \mathrm{E}+00$ & $3.66 \mathrm{E}-02$ \\
\hline B1LB08A & C5380 & 51.3 & $1.91 \mathrm{E}-01$ & $1.31 \mathrm{E}-01$ & $1.09 \mathrm{E}+00$ & $6.05 \mathrm{E}-02$ \\
\hline B1LB08B & C5380 & 50.8 & $2.08 \mathrm{E}-01$ & $1.43 \mathrm{E}-01$ & $1.19 \mathrm{E}+00$ & $6.55 \mathrm{E}-02$ \\
\hline B1LB08C & C5380 & 50.3 & $2.70 \mathrm{E}-01$ & $1.88 \mathrm{E}-01$ & $1.57 \mathrm{E}+00$ & $8.18 \mathrm{E}-02$ \\
\hline \hline
\end{tabular}

\subsection{Tier II Sample Investigations}

Upon completion of the Tier I testing, a subset of samples from the T Tank Farm direct push sampling campaign were subjected to Tier II analyses or interpretations. These additional efforts were performed to 1) further investigate the discrepancy between water-extractable and acid-leachable technetium-99 in the T direct push samples, 2) see if ruthenium isotopic analyses could be used to identify contaminant source terms, and 3) see if chloride data generated during the 1:1 sediment:water extraction process could be used to investigate the effect of the tank drip line on recharge. Results from Tier II tests and analyses are presented in the following sections. 


\subsubsection{Technetium-99 Extraction and Analysis}

The 1:1 sediment:water-extractable Tier II technetium-99 data pre- and post-resin treatment are presented in Tables 4.30 and 4.31 in units of $\mu \mathrm{g} / \mathrm{g}$. The data for the triplicate samples have been averaged, and the percent relative standard deviation (\%RSD), based on one standard deviation, for the triplicate samples has been calculated. Also contained in the tables are the total technetium- 99 recoveries for a blank spike and two matrix spikes that were prepared with each sample set. The \%RSDs for the 1:1 sediment:water extract samples that were not resin-treated (Table 4.30) were excellent. For the four sample sets that contained technetium-99 in excess of the limit of quantification for analysis, the \%RSDs ranged from 0.759 to $2.30 \%$. As expected, the background sediment collected from the Integrated Low Activity Waste (ILAW) borehole (C3177) did not contain a quantifiable amount of technetium-99. Spike recoveries performed as quality control for this data set had mixed results. Generally, recoveries in excess of $85 \%$ are considered acceptable, and two of the samples met this criterion: the blank spike and the background sediment matrix spike. However, the direct push sample matrix spike had a total recovery of only $62.8 \%$. The low recovery associated with this sample is surprising given the overall success of the two other spiked samples. The samples underwent minimal processing after being spiked; therefore, the most likely cause of the low technetium-99 recovery in the direct push matrix spike was due to improper addition of the spike. Although the data are reported in different units herein (mass instead of activity), comparison of the results in Table 4.30 to those generated during the Tier I sediment:water extracts also yielded mixed results. For two of the three samples where comparative data was available, the agreement was excellent; the relative percent difference between data sets was $1.96 \%$ for sample B1KC40A and $9.97 \%$ for sample B1KC40B. However, agreement for sample B1KC40C was poor, with a relative difference of $44 \%$. Given the internal agreement between triplicate sediment:water extracts performed on sediment from B1KC40C during Tier II testing, it appears that the $44 \%$ difference in technetium-99 concentrations between the two data sets was a result of heterogeneity of the sample (the sample was mixed well prior to Tier II testing).

Table 4.30. Water-Extractable Technetium-99 Concentrations in the T Tank Farm Vadose Zone Samples

\begin{tabular}{|c|c|c|c|c|c|}
\hline $\begin{array}{l}\text { Sample } \\
\text { ID }\end{array}$ & $\begin{array}{l}\text { Probe Hole } \\
\text { ID }\end{array}$ & $\begin{array}{l}\text { Mid-Depth } \\
\mathrm{ft} \text { bgs }\end{array}$ & $\begin{array}{c}\text { Technetium-99 } \\
\mu \mathrm{g} / \mathrm{g}\end{array}$ & $\begin{array}{l}\text { Relative Standard } \\
\text { Deviation (\%) }\end{array}$ & $\begin{array}{c}\text { Technetium-99 } \\
\text { Recovery (\%) }\end{array}$ \\
\hline B1KC40 & $\overline{C \text { C5374 }}$ & 81.8 & $1.10 \mathrm{E}-03$ & 2.30 & $\overline{\mathrm{NA}}$ \\
\hline $\mathrm{B} 1 \mathrm{KC} 40 \mathrm{~A}$ & C5374 & 81.3 & $4.57 \mathrm{E}-03$ & 1.89 & NA \\
\hline $\mathrm{B} 1 \mathrm{KC} 40 \mathrm{~B}$ & C5374 & 80.8 & $5.16 \mathrm{E}-03$ & 1.42 & NA \\
\hline B1KC40C & C5374 & 80.3 & $2.31 \mathrm{E}-03$ & 0.759 & NA \\
\hline B1KC40-MS & C5382 & 79.3 & NA & NA & 62.8 \\
\hline C3177 & C5382 & NA & $(4.92 \mathrm{E}-05)$ & 79.5 & NA \\
\hline C3177-MS & C5382 & NA & NA & NA & 90.1 \\
\hline Blank Spike & NA & NA & NA & NA & 86.6 \\
\hline
\end{tabular}


Table 4.31. Water-Extractable Technetium-99 Concentrations in the T Tank Farm Vadose Zone Samples After TEVA Resin Treatment

\begin{tabular}{|c|c|c|c|c|c|}
\hline $\begin{array}{l}\text { Sample } \\
\text { ID }\end{array}$ & $\begin{array}{l}\text { Probe Hole } \\
\text { ID }\end{array}$ & $\begin{array}{l}\text { Mid-Depth } \\
\text { ft bgs }\end{array}$ & $\begin{array}{c}\text { Technetium-99 } \\
\mu \mathrm{g} / \mathrm{g}\end{array}$ & $\begin{array}{c}\text { Relative Standard } \\
\text { Deviation (\%) }\end{array}$ & $\begin{array}{l}\text { Technetium-99 } \\
\text { Recovery (\%) }\end{array}$ \\
\hline$\overline{\mathrm{B} 1 \mathrm{KC} 40}$ & C5374 & 81.8 & $9.92 \mathrm{E}-04$ & 2.57 & NA \\
\hline $\mathrm{B} 1 \mathrm{KC} 40 \mathrm{~A}$ & C5374 & 81.3 & $4.64 \mathrm{E}-03$ & 4.08 & NA \\
\hline $\mathrm{B} 1 \mathrm{KC} 40 \mathrm{~B}$ & C5374 & 80.8 & $5.04 \mathrm{E}-03$ & 2.60 & NA \\
\hline B1KC40C & C5374 & 80.3 & $2.15 \mathrm{E}-03$ & 1.09 & NA \\
\hline B1KC40-MS & C5382 & 79.3 & NA & NA & 62.2 \\
\hline C3177 & C5382 & NA & $<1.42 \mathrm{E}-06$ & NA & NA \\
\hline C3177-MS & C5382 & NA & NA & NA & 90.0 \\
\hline Blank Spike & NA & NA & NA & NA & 84.9 \\
\hline \multicolumn{6}{|c|}{$\begin{array}{l}\text { Shaded cells indicate grab sample. } \\
\text { MS indicates matrix spike. } \\
\text { Less than values indicate the instrument returned a negative value. } \\
\text { NA indicates not applicable. }\end{array}$} \\
\hline
\end{tabular}

The \%RSDs for the 1:1 sediment:water extract samples that were treated with TEVA® resin (Table 4.31) were also excellent. For the four sample sets that contained technetium-99 in excess of the limit of quantification for analysis, the \%RSDs ranged from 1.09 to $4.08 \%$. Consistent with the nonresin-treated samples, the background sediment (C3177) did not contain a quantifiable amount of technetium-99. Spike recoveries for the aliquots of sample that were treated with the resin had the same mixed results as the non-treated aliquots. Once again, the blank spike and the background sediment matrix spike both had recoveries of $85 \%$ or greater. However, the direct push sample matrix spike had a total recovery of only $62.2 \%$ (which was identical to the matrix spike recovery of $62.8 \%$ for the nontreated samples). The fact that this sample had low recovery through two analytical processes lends support to the hypothesis that an inappropriate amount of technetium-99 was initially spiked into the sample prior to processing via the 1:1 sediment:water extraction technique (i.e. the laboratory technician spiked the sample with less technetium-99 than was recorded on their bench sheets). was initially spiked into the sample prior to processing via the 1:1 sediment:water extraction technique. Comparison of the data in Table 4.31 to the non-resin-treated data in Table 4.30 showed excellent agreement between the analyses. Relative differences between the two data sets for average concentrations of the samples from probe hole $\mathrm{C} 5374$ (as measured via the three replicate samples) ranged from $1.42 \%$ to $9.97 \%$. These results indicate that technetium-99 reported in the 1:1 sediment:water extracts is indeed technetium-99 (i.e., a matrix interference is not present in these samples). These results show that the additional step of treating the samples with TEVA ${ }^{\circledR}$ resin is not necessary when quantifying technetium-99 in water extract samples.

The $8 \mathrm{M}$ nitric acid extractable Tier II technetium- 99 data pre- and post-resin treatment are presented in Tables 4.32 and 4.33 in units of $\mu \mathrm{g} / \mathrm{g}$. Once again, the data for the triplicate samples has been averaged, and the percent relative standard deviation (\%RSD) based on one standard deviation for the triplicate samples has been calculated. Also contained in the tables are the total technetium-99 recoveries for the blank spike and two matrix spikes that were prepared with each sample set. The \%RSDs for the $8 \mathrm{M}$ nitric acid extract samples that were not resin-treated (Table 4.32) were acceptable, although they weren't as good as those for the water extract samples. For the three sample sets that contained technetium-99 in excess of the limit of quantification for analysis, the \%RSDs ranged from $6.39 \%$ to 12.5\%. As expected, the background sediment collected from the Integrated Low Activity Waste (ILAW) 
Table 4.32. Acid Extractable Technetium-99 Concentrations in the T Tank Farm Vadose Zone

\begin{tabular}{|c|c|c|c|c|c|}
\hline $\begin{array}{c}\text { Sample } \\
\text { ID }\end{array}$ & $\begin{array}{c}\text { Probe Hole } \\
\text { ID }\end{array}$ & $\begin{array}{l}\text { Mid-Depth } \\
\mathrm{ft} \text { bgs }\end{array}$ & $\begin{array}{c}\text { Technetium-99 } \\
\mu \mathrm{g} / \mathrm{g}\end{array}$ & $\begin{array}{l}\text { Relative Standard } \\
\text { Deviation }(\%)\end{array}$ & $\begin{array}{c}\text { Technetium-99 } \\
\text { Recovery (\%) }\end{array}$ \\
\hline $\mathrm{B} 1 \mathrm{KC} 40$ & C5374 & 81.8 & $(1.71 \mathrm{E}-03)$ & 4.27 & NA \\
\hline $\mathrm{B} 1 \mathrm{KC} 40 \mathrm{~A}$ & C5374 & 81.3 & $5.50 \mathrm{E}-03$ & 6.73 & NA \\
\hline B1KC40B & C5374 & 80.8 & $5.93 \mathrm{E}-03$ & 6.39 & NA \\
\hline B1KC40C & C5374 & 80.3 & $5.93 \mathrm{E}-03$ & 12.5 & NA \\
\hline B1KC40-MS & C5382 & 79.3 & NA & $\mathrm{NA}$ & 88.7 \\
\hline C3177 & C5382 & NA & $(1.15 \mathrm{E}-04)$ & 40.5 & $\mathrm{NA}$ \\
\hline C3177-MS & C5382 & NA & NA & NA & 89.5 \\
\hline Blank Spike & NA & NA & NA & NA & 87.5 \\
\hline \multicolumn{6}{|c|}{$\begin{array}{l}\text { Shaded cells indicate grab sample. } \\
\text { MS indicates matrix spike. } \\
\text { Parentheses indicate the reported value is below the limit of quantification for the analysis. } \\
\text { NA indicates not applicable. }\end{array}$} \\
\hline
\end{tabular}

Table 4.33. Acid Extractable Technetium-99 Concentrations in the T Tank Farm Vadose Zone After Resin Treatment

\begin{tabular}{|c|c|c|c|c|c|}
\hline $\begin{array}{c}\text { Sample } \\
\text { ID } \\
\end{array}$ & $\begin{array}{c}\text { Probe Hole } \\
\text { ID } \\
\end{array}$ & $\begin{array}{c}\text { Mid-Depth } \\
\mathrm{ft} \text { bgs } \\
\end{array}$ & $\begin{array}{c}\text { Technetium-99 } \\
\mu \mathrm{g} / \mathrm{g} \\
\end{array}$ & $\begin{array}{c}\text { Relative Standard } \\
\text { Deviation }(\%) \\
\end{array}$ & $\begin{array}{l}\text { Technetium-99 } \\
\text { Recovery (\%) } \\
\end{array}$ \\
\hline B1KC40 & C5374 & 81.8 & (1.38E-03) & 8.92 & NA \\
\hline $\mathrm{B} 1 \mathrm{KC} 40 \mathrm{~A}$ & C5374 & 81.3 & $4.81 \mathrm{E}-03$ & 3.44 & NA \\
\hline $\mathrm{B} 1 \mathrm{KC} 40 \mathrm{~B}$ & C5374 & 80.8 & $5.35 \mathrm{E}-03$ & 6.15 & NA \\
\hline $\mathrm{B} 1 \mathrm{KC} 40 \mathrm{C}$ & C5374 & 80.3 & $5.34 \mathrm{E}-03$ & 12.9 & $\mathrm{NA}$ \\
\hline B1KC40-MS & C5382 & 79.3 & $\mathrm{NA}$ & $\mathrm{NA}$ & 46.7 \\
\hline C3177 & C5382 & $\mathrm{NA}$ & $(1.45 \mathrm{E}-05)$ & 52.2 & $\mathrm{NA}$ \\
\hline C3177-MS & C5382 & NA & NA & NA & 72.8 \\
\hline Blank Spike & $\mathrm{NA}$ & NA & NA & NA & 80.5 \\
\hline \multicolumn{6}{|c|}{$\begin{array}{l}\text { Shaded cells indicate grab sample. } \\
\text { MS indicates matrix spike. } \\
\text { Parentheses indicate the reported value is below the limit of quantification for the analysis. } \\
\text { NA indicates not applicable. }\end{array}$} \\
\hline
\end{tabular}

borehole (C3177) did not contain a quantifiable amount of acid-extractable technetium-99. Spike recoveries performed as quality control for this data set worked quite well. All three spikes, the blank spike, the background sediment matrix spike, and the direct push sample matrix spike all had recoveries in excess of $85 \%$. These results indicate that technetium- 99 is stable throughout the $8 \mathrm{M}$ nitric acid extraction process. Although the data are reported in different units herein, comparison of the results in Table 4.32 to those generated during the Tier I 8M nitric acid extracts also yielded mixed results. For two of the three samples where comparative data was available, the agreement was excellent; the relative percent difference between data sets was $4.62 \%$ for sample $\mathrm{B} 1 \mathrm{KC} 40 \mathrm{~A}$ and $0.338 \%$ for sample $\mathrm{B} 1 \mathrm{KC} 40 \mathrm{~B}$. However, agreement for sample B1KC40C was poor, with a relative difference of $28.6 \%$. The fact that discrepancies arose between the water extract Tier I and Tier II data sets for this sample, combined with the differences measured here, implies that sample heterogeneity was the lead cause of the discrepancies.

The \%RSDs for the $8 \mathrm{M}$ nitric acid extract samples that were treated with TEVA ${ }^{\circledR}$ resin (Table 4.33) were slightly better than those for the non-treated samples. For the three sample sets that contained technetium-99 in excess of the limit of quantification for analysis, the \%RSDs ranged from $3.44 \%$ to $12.9 \%$. Consistent with the non-resin-treated samples, the background sediment (C3177) did not contain 
a quantifiable amount of technetium-99. Spike recoveries for the aliquots of sample that were treated with the resin were inadequate. None of the TEVA ${ }^{\circledR}$ resin-treated spikes had recoveries of $85 \%$ or greater. Additionally, the direct push matrix spike sample (B1KC40C-MS) only had a recovery of $46.7 \%$. The best spike recovery for the resin-treated nitric acid extracts occurred in the blank spike, which had a total technetium-99 recovery of $80.5 \%$. These results clearly indicate that technetium-99 was lost between the $8 \mathrm{M}$ nitric acid extraction step (which generated the data in Table 4.32) and analysis of the resin-treated samples. In other words, something that occurred during processing of the samples in preparation for the resin treatment step, or the resin treatment step itself, caused the poor recoveries measured with this data set. The two most probable steps that could have led to a deficiency in technetium-99 recoveries were heating of the samples to dryness once the $8 \mathrm{M}$ nitric acid extracts were complete (this step was performed to change the sample matrix prior to its addition to the TEVA columns), or fouling of the resin columns by the high concentrations of dissolved solids in the acid extract samples. Both of these potential issues could be corrected for through the addition of a tracer (such as technetium-95 m) to the extracts prior to processing them for resin treatment. Using this approach, recoveries for each sample could be measured, and the reported technetium-99 concentrations could be appropriately corrected for each sample.

Although there were issues with the total recovery of technetium-99 through the resin treatment process, the results of this test do allow for some conclusions to be drawn for the Tier II acid extract data (and subsequently to the Tier I acid extract data). Comparison of the acid extract data in Table 4.33 to the non-resin-treated data in Table 4.32 shows good agreement between the analyses. Relative differences between the two data sets for average concentrations of the samples from probe hole C5374 (as measured via the three replicate samples) ranged from $10.3 \%$ to $13.3 \%$ (the technetium-99 concentrations in the resin-treated acid extract samples were consistently lower than those in the untreated samples). There was exceptionally good agreement between the data sets given the low total recoveries measured after resin treatment of the samples. Additionally, it appears that a matrix effect is not the cause of the elevated technetium-99 in the acid extracts vs. the water extracts. These results imply that some credence should be given to the $8 \mathrm{M}$ acid extract technetium-99 data. However, before quantitative results are provided, the $8 \mathrm{M}$ nitric acid extracts should be taken through the resin treatment process again after the addition of a tracer to monitor recoveries through the treatment steps.

The microwave-digested Tier II technetium-99 results pre- and post-resin treatment are presented in Tables 4.34 and 4.35 in units of $\mu \mathrm{g} / \mathrm{g}$. Once again, the data for the triplicate samples has been averaged, and the percent relative standard deviation (\%RSD), based on one standard deviation, for the triplicate samples has been calculated. Also contained in the tables are the total technetium-99 recoveries for the blank spike and two matrix spikes that were prepared with each sample set. The \%RSDs for the microwave digests that were not resin-treated (Table 4.34) were not valid, given that technetium-99 was not measured above the limit of quantification for the analysis. Microwave digestion generates greater sample dilution due to a higher solution to solid ratio (100:1 vs. approximately $6: 1$ for the nitric acid extracts and 1:1 for the sediment:water extracts). On a positive note, spike recoveries performed as quality control for this data set worked quite well. All three spikes - the blank spike, the background sediment matrix spike, and the direct push sample matrix spike — had recoveries in excess of $85 \%$. These results indicate that technetium-99 is stable throughout the microwave digestion process, but higher sample concentrations are necessary to alleviate detection limit issues associated with the technique. Given the lack of quantitative data, results in Table 4.34 cannot be compared with total technetium- 99 concentrations measured via the other two extraction techniques. 
Table 4.34. Microwave Digestible Technetium-99 Concentrations in the T Tank Farm Vadose Zone

\begin{tabular}{|c|c|c|c|c|c|}
\hline $\begin{array}{c}\text { Sample } \\
\text { ID }\end{array}$ & $\begin{array}{c}\text { Probe Hole } \\
\text { ID }\end{array}$ & $\begin{array}{l}\text { Mid-Depth } \\
\mathrm{ft} \text { bgs }\end{array}$ & $\begin{array}{c}\text { Technetium-99 } \\
\mu \mathrm{g} / \mathrm{g}\end{array}$ & $\begin{array}{c}\text { Relative Standard } \\
\text { Deviation }(\%)\end{array}$ & $\begin{array}{c}\text { Technetium-99 } \\
\text { Recovery }(\%) \\
\end{array}$ \\
\hline $\mathrm{B} 1 \mathrm{KC} 40$ & C5374 & 81.8 & (1.31E-03) & 15.5 & NA \\
\hline $\mathrm{B} 1 \mathrm{KC} 40 \mathrm{~A}$ & C5374 & 81.3 & $(3.63 \mathrm{E}-03)$ & 46.0 & $\mathrm{NA}$ \\
\hline $\mathrm{B} 1 \mathrm{KC} 40 \mathrm{~B}$ & C5374 & 80.8 & $(3.10 \mathrm{E}-03)$ & 18.2 & NA \\
\hline $\mathrm{B} 1 \mathrm{KC} 40 \mathrm{C}$ & C5374 & 80.3 & (5.27E-03) & 63.2 & NA \\
\hline B1KC40-MS & C5382 & 79.3 & NA & NA & 91.7 \\
\hline C3177 & C5382 & NA & $<2.18 \mathrm{E}-02$ & NA & NA \\
\hline C3177-MS & C5382 & NA & NA & $\mathrm{NA}$ & 85.6 \\
\hline Blank Spike & NA & NA & NA & NA & 86.5 \\
\hline \multicolumn{6}{|c|}{$\begin{array}{l}\text { Shaded cells indicate grab sample. } \\
\text { MS indicates matrix spike. } \\
\text { Parentheses indicate the reported value is below the limit of quantification for the analysis. } \\
\text { Less than values indicate the instrument returned a negative value. } \\
\text { NA indicates not applicable. }\end{array}$} \\
\hline
\end{tabular}

Table 4.35. Microwave Digestible Technetium-99 Concentrations in the T Tank Farm Vadose Zone After Resin Treatment

\begin{tabular}{|c|c|c|c|c|c|}
\hline $\begin{array}{l}\text { Sample } \\
\text { ID }\end{array}$ & $\begin{array}{c}\text { Probe Hole } \\
\text { ID }\end{array}$ & $\begin{array}{l}\text { Mid-Depth } \\
\text { ft bgs }\end{array}$ & $\begin{array}{c}\text { Technetium-99 } \\
\mu \mathrm{g} / \mathrm{g}\end{array}$ & $\begin{array}{c}\text { Relative Standard } \\
\text { Deviation }(\%)\end{array}$ & $\begin{array}{c}\text { Technetium-99 } \\
\text { Recovery (\%) }\end{array}$ \\
\hline B1KC40 & "C5374 & 81.8 & $\begin{array}{c}1.50 \mathrm{E}-03 \\
\end{array}$ & 12.1 & NA \\
\hline $\mathrm{B} 1 \mathrm{KC} 40 \mathrm{~A}$ & C5374 & 81.3 & $4.15 \mathrm{E}-03$ & 3.82 & NA \\
\hline B1KC40B & $\begin{array}{l}\mathrm{C} 5374 \\
\end{array}$ & 80.8 & $4.73 \mathrm{E}-03$ & 28.5 & NA \\
\hline B1KC40C & C5374 & 80.3 & $6.76 \mathrm{E}-03$ & 42.0 & NA \\
\hline B1KC40-MS & C5382 & 79.3 & NA & NA & 73.1 \\
\hline C3177 & C5382 & NA & $<8.71 \mathrm{E}-05$ & NA & NA \\
\hline C3177-MS & C5382 & NA & NA & NA & 86.5 \\
\hline Blank Spike & NA & NA & NA & NA & 39.1 \\
\hline \multicolumn{6}{|c|}{$\begin{array}{l}\text { Less than values indicate the instrument returned a negative value. } \\
\text { Shaded cells indicate grab sample. } \\
\text { MS indicates matrix spike. } \\
\text { NA indicates not applicable. }\end{array}$} \\
\hline
\end{tabular}

Treatment of the microwave-digested samples with TEVA ${ }^{\circledR}$ resin (Table 4.35) resulted in quantitative technetium-99 data for all of the direct push samples from probe hole C5374. However, the $\%$ RSDs for the microwave digested samples varied considerably. The \%RSDs for the four direct push sample sets ranged from $15.5 \%$ to $63.2 \%$. Consistent with the non-resin-treated samples, the background sediment (C3177) did not contain a quantifiable amount of technetium-99. Spike recoveries for the aliquots of sample that were treated with the resin were sporadic. One of the TEVA ${ }^{\circledR}$ resin-treated spikes (the background matrix spike) had a recovery of greater than $85 \%$. The T Tank Farm direct push sample matrix spike had a recovery of 73.1 and ironically, the blank spike had the poorest recovery at just $39.1 \%$. As with the acid extract data, these results clearly indicate that technetium-99 was lost between the microwave digestion step (which generated the data in Table 4.34) and analysis of the resin-treated samples. The same two steps that could have led to a deficiency in technetium-99 recoveries in the $8 \mathrm{M}$ nitric acid extracts are suspected as being the primary culprits with these poor recoveries on these samples as well. Again, both of these potential issues, heating of the samples to dryness or fouling of the resin 
columns, could be accounted for through the addition of a tracer to the extracts prior to processing them for resin treatment. Using this approach, recoveries for each sample could be measured, and the reported technetium-99 concentrations could be appropriately corrected for each sample.

Even though there were issues with the total recovery of technetium-99 with this data set, these results can be used to qualitatively assess the thoroughness of the Tier I water and acid extraction techniques. Comparison of the data in Table 4.35 to water and acid extract results contained in Tables 4.30 through 4.33 shows that significantly more technetium-99 can be extracted via nitric acid or with the aid of microwave digestion than was released using water as the leachant. For example, the two Tier II water extraction tests leached an average of $2.23 \mathrm{E}-03 \mu \mathrm{g} / \mathrm{g}$ technetium- 99 from samples B1KC40C. These results were approximately a factor of two higher than the amount leached from this sample material during Tier I testing of the direct push samples. Comparatively, 7.91E- $03 \mu \mathrm{g} / \mathrm{g}$ technetium-99 was acid leached from this sample during Tier I testing. Tier II acid extraction of this sample resulted in 5.93E-03 $\mu \mathrm{g} / \mathrm{g}$ and 5.34E-03 $\mu \mathrm{g} / \mathrm{g}$ technetium-99 in the non-treated and resin-treated samples, respectively. Additionally, the resin-treated technetium-99 could be biased low due to loss of technetium through the treatment process. Finally, resin-treated microwave digests of this sample resulted in an average technetium- 99 concentration of $6.76 \mathrm{E}-03 \mu \mathrm{g} / \mathrm{g}$. Again, this result could be biased low due to loss of technetium-99 through the separation process. It is difficult to assign quantitative numbers to the Tier II resin-treated data given the poor recoveries and less-than-optimal reproducibility of the data. However, given that large discrepancies in total technetium-99 concentrations among the various extraction techniques (with water extraction consistently being lowest), still existed after resin treatment of the acid extracts and microwave digests, serious thought must be given to the validity of using water-extractable technetium-99 data as the basis for determining total technetium-99 in the sediments.

\subsubsection{Stable Ruthenium Isotopic Analysis}

Two samples from borehole C4104 (emplaced near tank 241-T-106) (Serne et al. 2004b) were processed in conjunction with similar sediments from probe hole C5374 and analyzed for stable ruthenium isotopes via ICP-MS. Ruthenium results from the various aliquots of samples post-resin treatment are presented in Figure 4.19. The data are plotted as the isotopic ratios of ruthenium102:ruthenium-104 vs. ruthenium-101:ruthenium-104. Also contained in the plot are the isotopic ratio data for natural ruthenium standards that were analyzed as part of the quality control associated with this data set. The plot is a triangle, with each end point of the triangle representing a different source of ruthenium. The three sources include natural ruthenium, ruthenium produced during uranium-235 fission, and ruthenium produced during plutonium-239 fission. The dashed lines contained within the figure represent mixing lines between the respective end members. If ruthenium measured in the samples is present from a single source, the data will plot at the appropriate end member, as was the case for the natural ruthenium standards. However, when samples contain multiple sources of ruthenium, they will plot on one of the mixing lines if their source is a mixture of two components or within the triangle if their source is a mixture of the three components. The data selected for plotting were only those results that had percent relative standard deviations of $7.5 \%$ or less based on three replicate analyses. Error bars contained within the plot represent one standard deviation.

All of the sediment water extract data analyzed plot on or near the mixing line between uranium-235 fission and plutonium-239 fission. Further, there appears to be two discrete "groups" of isotopic ratios associated with this data set. The upper group consists primarily of sediment samples collected from 
borehole C4104 at depths of approximately 76 and $81 \mathrm{ft}$ bgs. These specific samples from borehole C4104 were chosen for comparison because they bracket the depth of the T Tank Farm direct push samples processed and intercept the same stratigraphic unit (the Cold Creek Unit). Photographs of the samples are presented in Figures 4.20 through 4.24. The lower group contains all of the samples from probe hole $\mathrm{C} 5374$ that met the reporting criteria (which were only the $8 \mathrm{M} \mathrm{HNO}_{3}$ column elutions), as well as one of the column elutions from the $\mathrm{C} 4104$ borehole sample collected at $76 \mathrm{ft}$ bgs. As discussed in Section 3.3.4, several column fractions were collected as part of the resin treatment process, and each of these fractions were analyzed as discrete samples. As discussed in Section 3.3.4, several of the eluent fractions exiting the ion exchange column were collected as part of the resin treatment process, and each of these fractions were analyzed as discrete samples. This was performed to 1) monitor the samples for ruthenium existing in multiple valence states, 2) investigate isotopic fraction of ruthenium, 3) monitor the samples for mass interferences, which could bias isotopic ratios measured in select fractions.

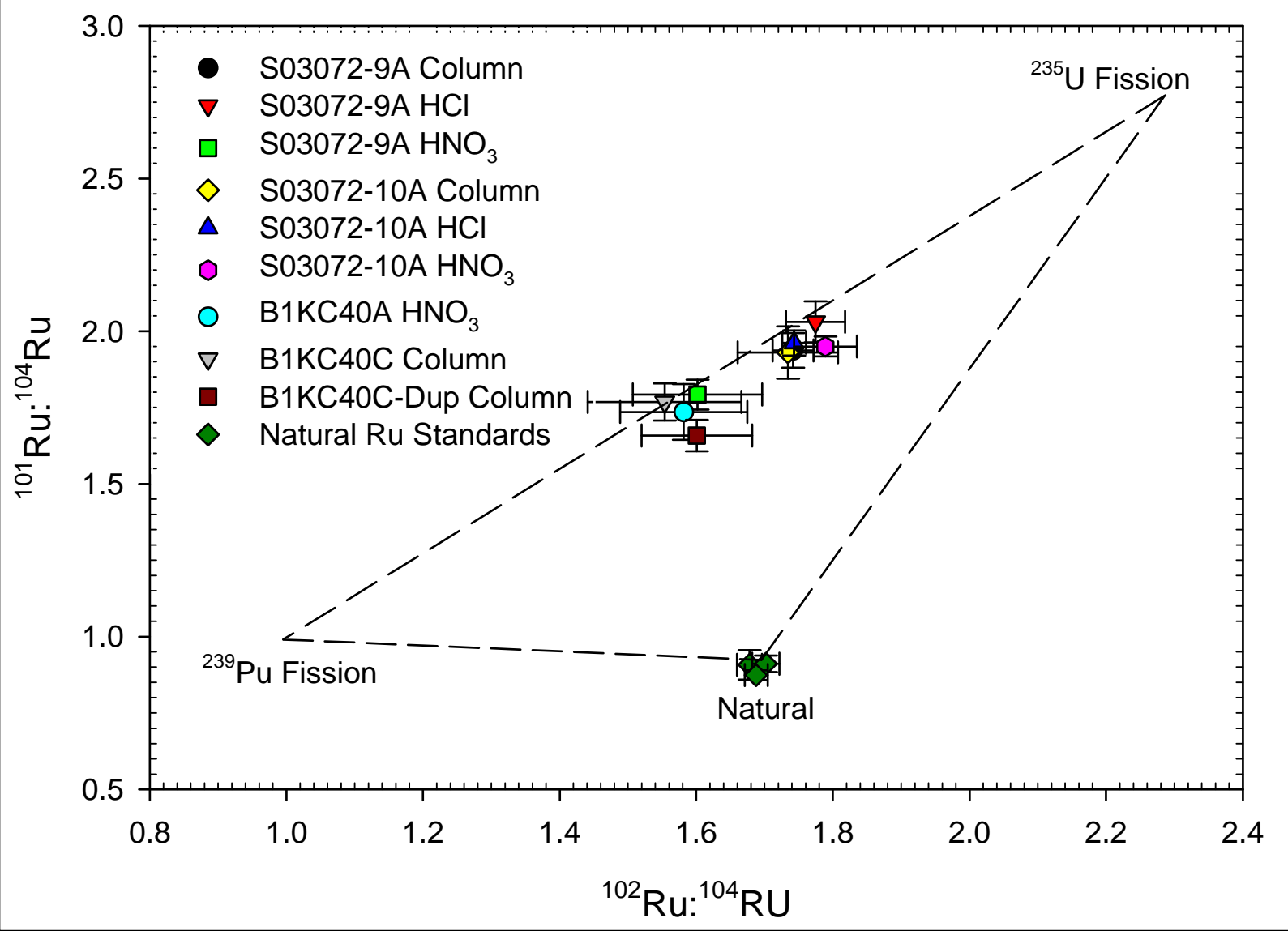

Figure 4.19. Ruthenium Isotopic Data from the T Tank Farm Direct Push Samples and Samples from Borehole C4104 


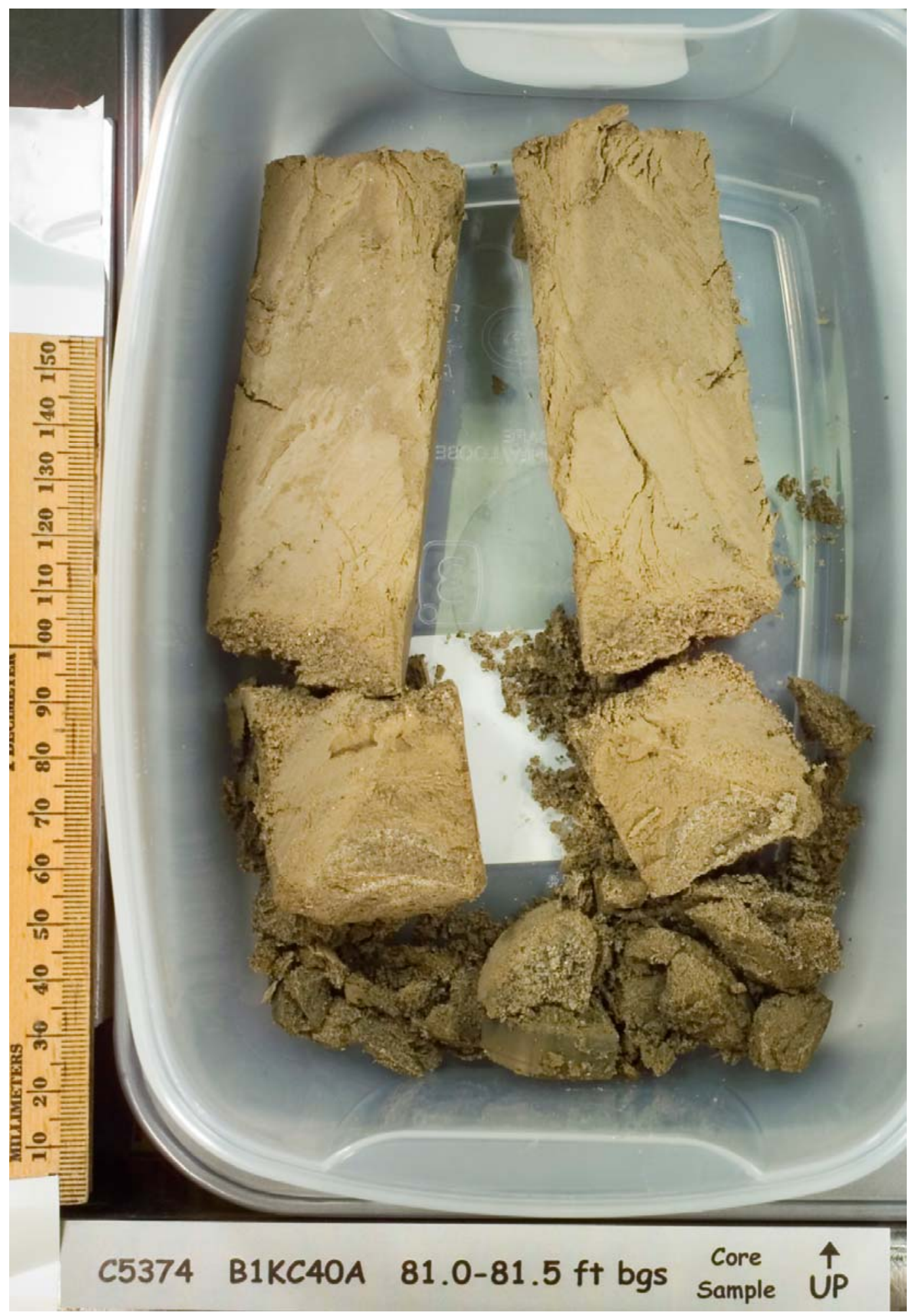

Figure 4.20. Photograph of Fine-Grained Upper Cold Creek Unit Sediment Recovered from 81.0 to $81.5 \mathrm{ft}$ bgs in Probe Hole C5374 


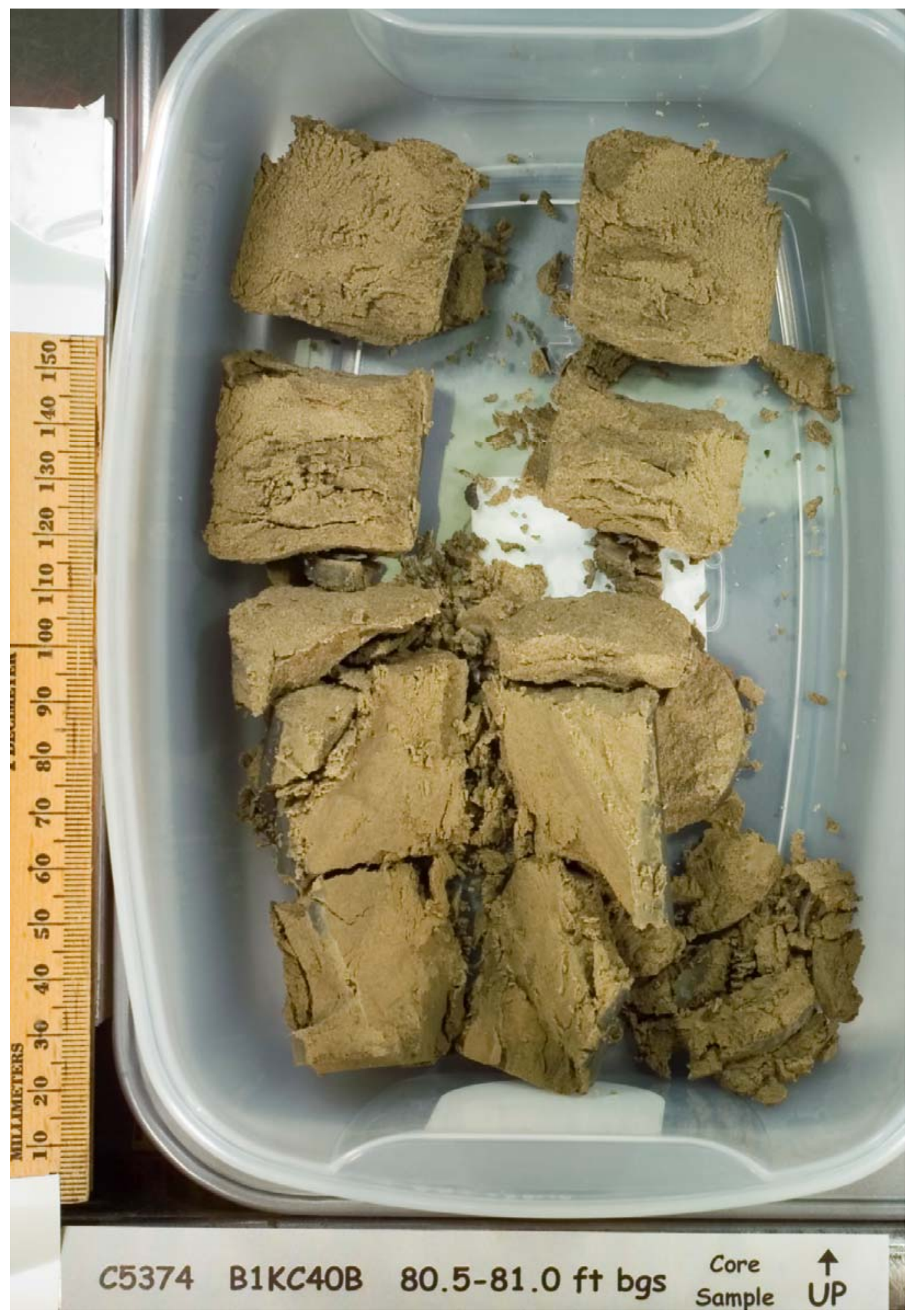

Figure 4.21. Photograph of Fine-Grained Upper Cold Creek Unit Sediment Recovered from 80.5 to $81.0 \mathrm{ft}$ bgs in Probe Hole C5374 


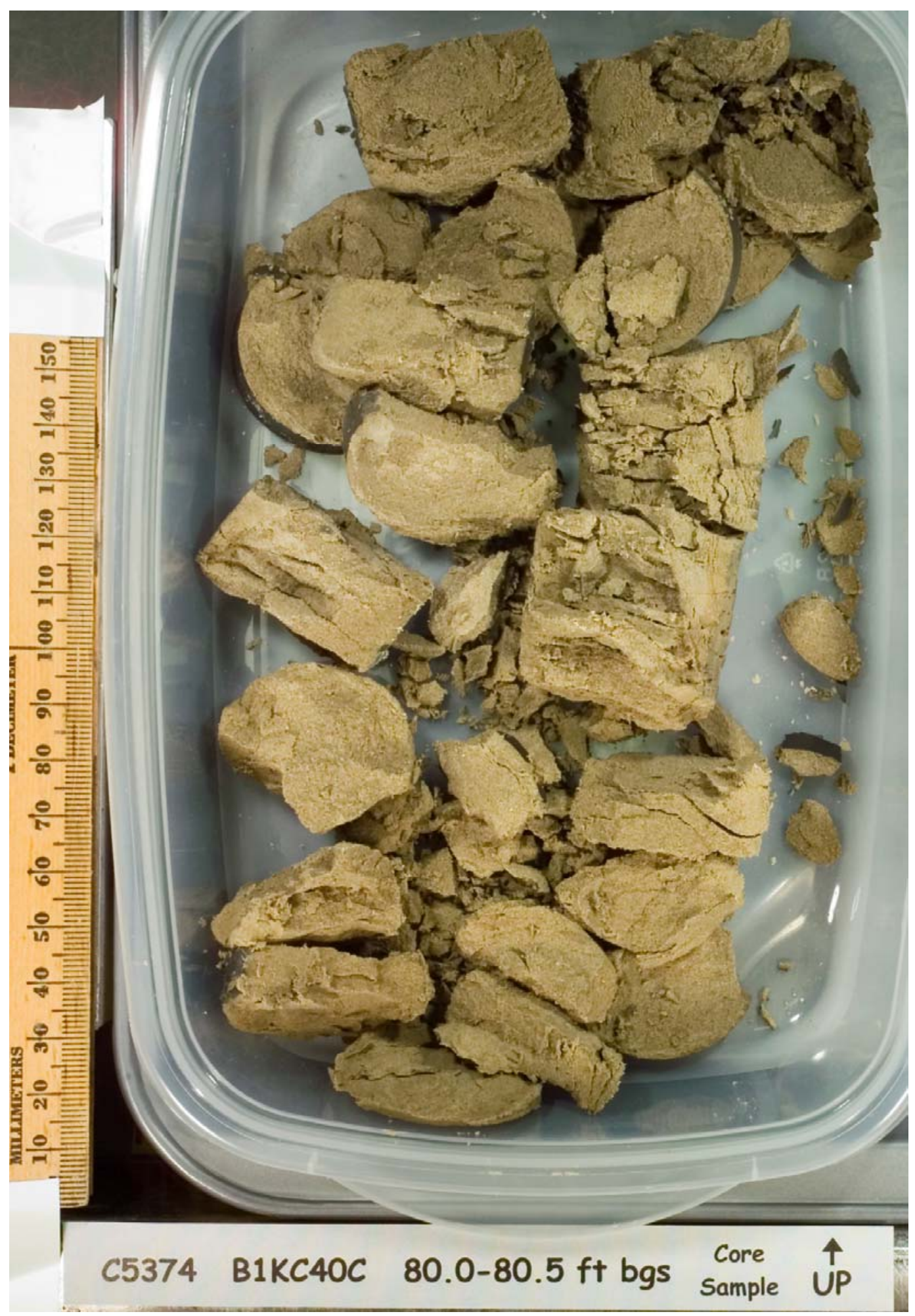

Figure 4.22. Photograph of Fine-Grained Upper Cold Creek Unit Sediment Recovered from 80.0 to $80.5 \mathrm{ft}$ bgs in Probe Hole C5374 


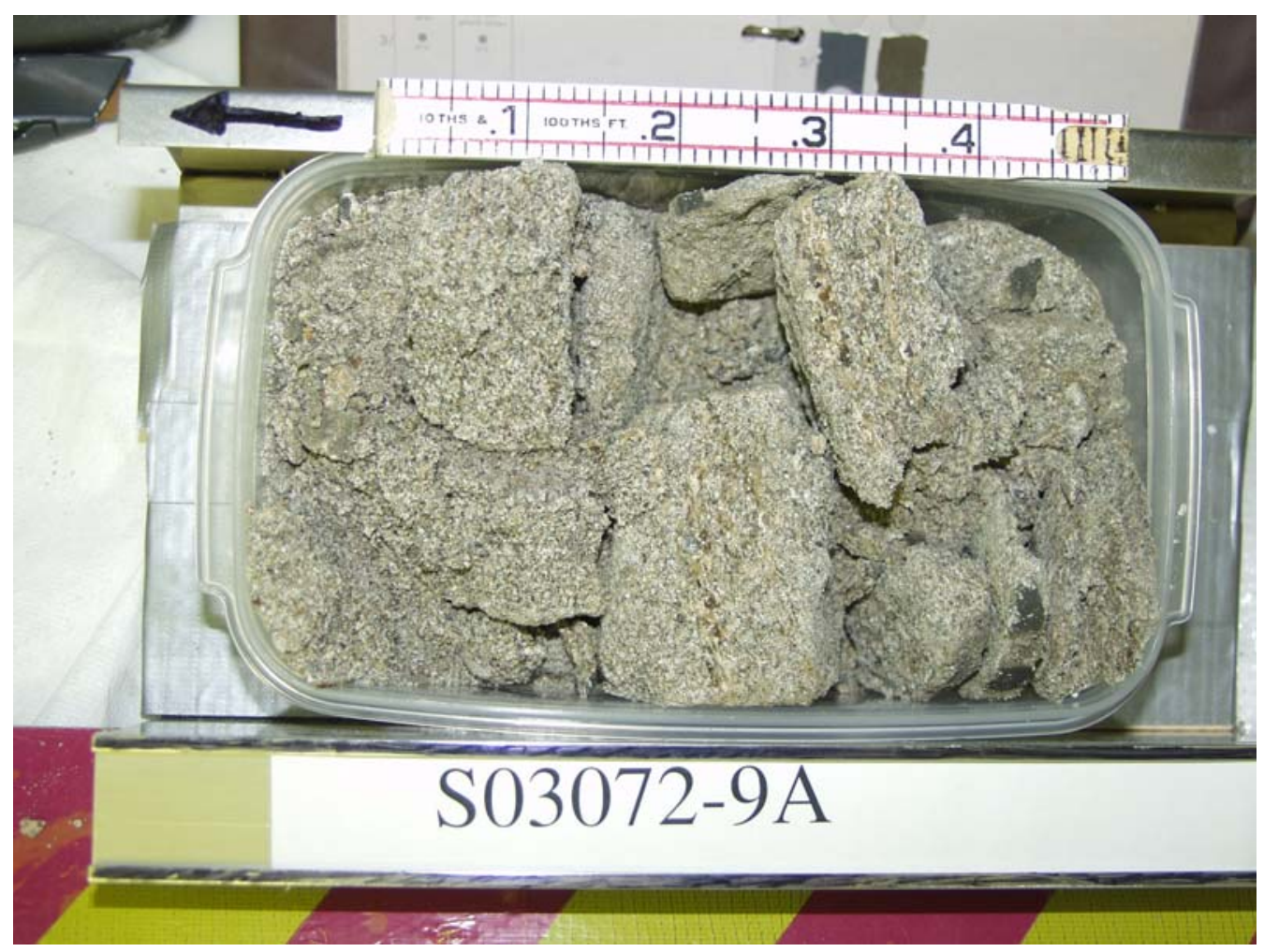

Figure 4.23. Photograph of Sediment Recovered from 75.1 to $75.7 \mathrm{ft}$ bgs in Borehole C4104

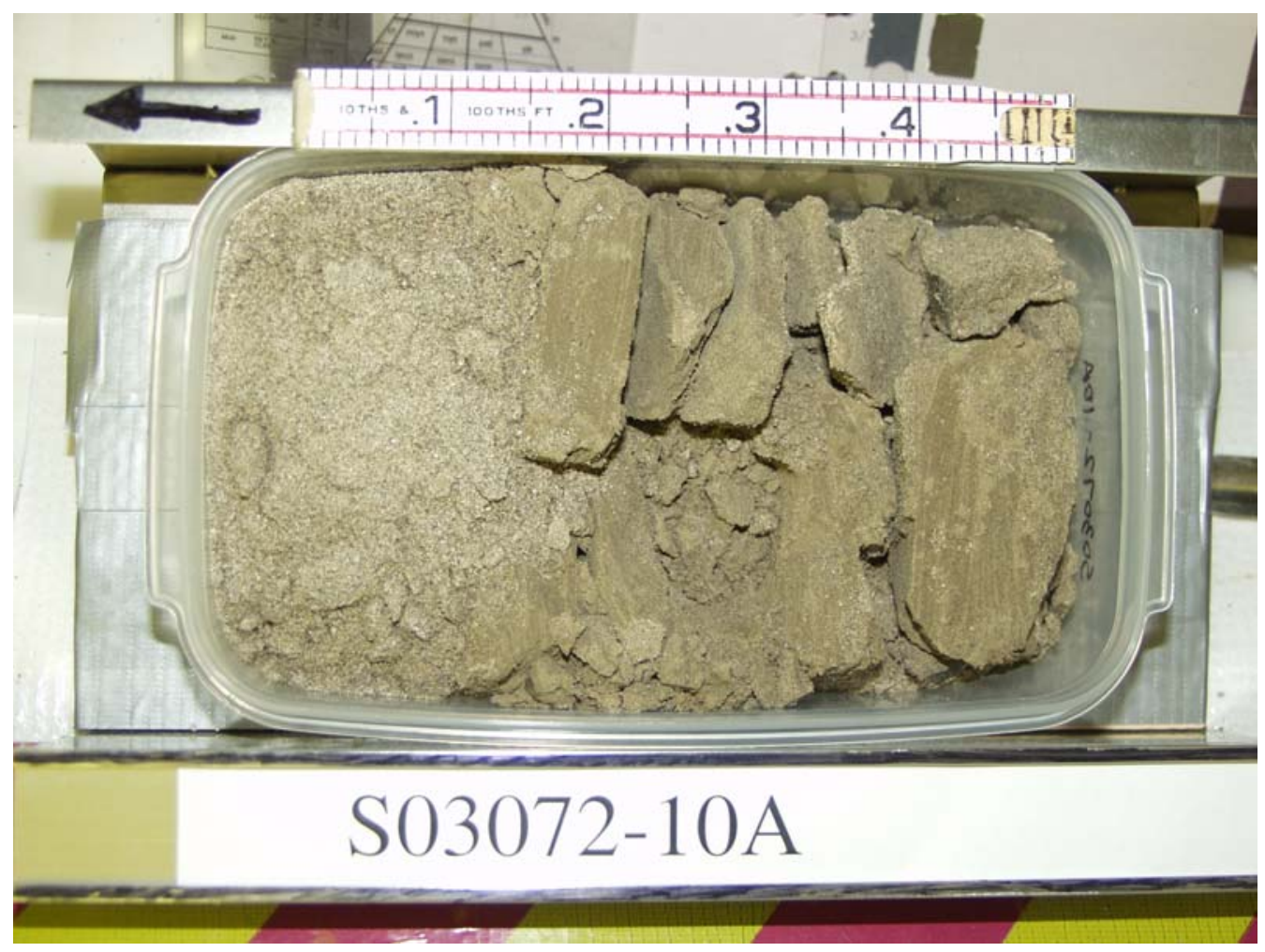

Figure 4.24. Photograph of Sediment Recovered from 80.1 to $80.7 \mathrm{ft}$ bgs in Borehole C4104 
It is interesting that the data set that plots lower on the uranium-plutonium mixing line contains all the water extracts that were further treated through the anion exchange resin for the $\mathrm{T}$ direct push samples from $\mathrm{B} 1 \mathrm{KC} 40$ and one of the $\mathrm{C} 4104$ borehole elutants, the nitric acid rinse of the anion exchange column for sample S03072-(A (from $76 \mathrm{ft} \mathrm{bgs).} \mathrm{However,} \mathrm{it} \mathrm{does} \mathrm{not} \mathrm{contain} \mathrm{all} \mathrm{of} \mathrm{the} 8 \mathrm{M} \mathrm{HNO}_{3}$ data; the upper group contains data for all of the elutions for the $\mathrm{C} 4104$ borehole sample collected from $81 \mathrm{ft}$ bgs (including the $8 \mathrm{M} \mathrm{HNO}_{3}$ elution). This indicates that the isotopic ratios measured in the lower plotting data set have not been biased low due to matrix interferences caused by the $8 \mathrm{M} \mathrm{HNO}_{3}$. Unfortunately, the total amount of ruthenium present in the $\mathrm{T}$ Tank Farm direct push samples was too low for any of the other elutions to contain sufficient ruthenium to provide data that met the reporting requirements (i.e., less than $7.5 \%$ relative standard deviation). Quantitative measurement of the column and $5 \% \mathrm{HCl}$ elutions from the direct push samples would be the best way to show that the lower ruthenium ratios present in these samples are indeed a result of the waste source term and are not associated with sample concentrations or matrices. One way to increase the total amount of ruthenium available for analysis would be to perform 1:1 sediment:water extracts using more sample mass; however, given that these samples were collected using the direct push technique, total sample mass is limited.

Given the shortcomings of the datasets, it is difficult to interpret the results with a high degree of confidence. However, based on the data, it does appear that multiple source terms (at least two) could be present in the $\mathrm{C} 4104$ borehole at the interface of the Hanford formation and the Cold Creek Unit. Additionally, one of the sources present at this location has a similar ruthenium isotopic ratio to those measured in the direct push samples collected from probe hole C5374. Since these samples were all collected at the interface of the Hanford formation and the Cold Creek Unit, it is possible that waste from the 241-T-101 tank leak migrated laterally to the southwest and can be observed in the C4104 borehole (Serne et al. [2004b] showed that the strata dip to the southwest in the T Tank Farm). Again, it is difficult to place an exact level of confidence on the interpretation of this data; however, it is supported by the stratigraphy in the area and certainly warrants further investigation.

\subsubsection{Estimating Recharge Using 1:1 Sediment:Water Extract Chloride Data}

The existing chloride data from the pushes at $\mathrm{T}$ Tank Farm are unsatisfactory for use in estimating recharge using the chloride mass balance (CMB) method. Part of what makes the data problematic for $\mathrm{CMB}$ is that the chloride profile is incomplete with much of the data being between 43 and $50 \mathrm{ft}$ bgs. Without some knowledge about the chloride profile, it can't be said if the chloride concentrations represent steady-state conditions, whether other transport processes are dominating (i.e., preferential flow), and if the chloride concentrations represent past or current recharge conditions. Another potential complicating factor is if a waste stream such as that resulting from a tank leak or overfill event resides at the sampling depths, the waste could alter the chloride concentration from what would otherwise be considered natural conditions. Obviously, the chemistry data associated with these samples indicates that tank waste constituents are present at the zones sampled by the direct push campaign.

Because the available chloride data is from multiple locations within T Tank Farm, an assumption must be made that conditions that would change recharge, such as evaporation and transpiration conditions, are the same at all vertical and horizontal locations. This is probably a safe assumption in this instance because push locations look to be relatively close to one another $(\sim 60 \mathrm{ft})$ and because the pushes are within a tank farm where the near surface sediment is homogenized backfill and vegetation is kept off. Outside of the tank farms in undisturbed areas, this assumption is not as plausible given that evapotranspiration conditions can vary over small distances. One other assumption that must be made to 
make this argument valid (homogeneous backfill material and not vegetated) is that the chloride data from the pushes represents chloride deposited on the soil surface under the current surface conditions. In other words, it represents current recharge conditions.

The CMB method cannot provide insight pertaining to the umbrella or shedding effect of tanks. Assuming the same chloride deposition and evapotranspiration conditions, the concentration of chloride next to the sides of a tank should not be different than the chloride some distance away from the tank. Divergence of water around the tanks will increase the water flux, but the concentration of chloride will not change.

Chloride-36 measurements on these push samples would not provide beneficial information for estimating recharge because the method relies on establishing the chloride-36 peak concentration, meaning that the chloride- 36 profile is needed. It is entirely possible that if one were to measure the chloride-36 profile next to the sidewall of a tank and away from the tank, the difference in water flux would be captured. This assumes that the peak chloride-36 deposition (from atmospheric bomb testing) in the mid-1950s post-dates construction of T Tank Farm.

The following types and quantity of samples are necessary in order to obtain a useful CMB dataset:

The collection of many depth-discrete undisturbed core samples is needed so that field moisture content conditions are captured. It's important that field moisture content be accurately determined in order to calculate pore water chloride concentrations.

Continuous, or near continuous, cores collected from near the ground surface to an appropriate depth to capture the chloride peak is necessary. Based on previous Hanford CMB studies, the chloride peak can range from $6 \mathrm{ft}$ to over $30 \mathrm{ft}$ bgs. The majority of the studies identified the chloride peak to be shallower than $30 \mathrm{ft}$ bgs. A helpful guide is to collect cores to a depth of $50 \mathrm{ft}$, with continuous cores being collected from near the surface to a depth of $30 \mathrm{ft}$ and cores collected every $3 \mathrm{ft}$ from 30 to $50 \mathrm{ft}$ bgs. 


\subsection{Summary and Observations}

In this section, summary information about the characterization of the T and TY Tank Farm direct push sediments is presented. Interpretation of the data has been included to aid in making decisions on what interim actions and future studies are needed to make sound remediation decisions at the T and TY Tank Farms.

\subsection{T and TX-TY Tank Farms Physical Geology Model}

Assessment of data from nearby boreholes coupled with analysis of material recovered from the direct push holes has led to the interpretation that the deposits beneath the T and TX-TY Tank Farms consist predominantly of the gravel-dominated Hanford formation $\mathrm{H} 1$ unit and sand-dominated Hanford formation $\mathrm{H} 2$ unit. These facies were deposited onto the giant Cold Creek bar during repeated Pleistocene cataclysmic floods. Beneath the Hanford formation is the Cold Creek unit, which consists of an upper fine sand to silt unit and a lower unit of variably cemented caliche, representing a buried paleosol sequence. Combined, the Cold Creek unit may be up to $40 \mathrm{ft}$ thick and its upper surface has a pronounced dip to the south. Below the Cold Creek unit is a discontinuous layer of Ringold Formation sand (Rtf) underlain by a thick sequence of variably cemented Ringold fluvial gravel (Rwi).

\subsection{TY Tank Farm Characterization Activities and Data}

The next several sections summarize geochemical and physical characterization data collected on sediment from the direct push holes emplaced within the TY Tank Farm. These characterization activities emphasized tests that provided basic characterization data and were fundamental to determining the distribution of mobile contaminants in the vadose zone sediments. Such information on the direct push sediments included moisture content, total and inorganic carbon content, $\mathrm{pH}$, electrical conductivity (EC), and measurements of major cations, anions, and trace metals (including technetium-99 and uranium-238) in 1:1 sediment:water extracts. Gamma energy analysis (GEA) of the sediments was also performed to search for any detectable man-made gamma-emitting radionuclides. In addition major cations, anions, and trace metals (including technetium-99 and uranium-238) were measured in $8 \mathrm{M}$ nitric acid extracts of the sediments to allow qualitative measurements of constituent mobility by comparing the water leachable to the acid extractable masses for each sample.

\subsubsection{Sampling Summary at the TY Tank Farm}

A geochemical investigation in the vicinity of tanks 241-TY-105 (UPR 200-W-152) and 241-TY-106 (UPR 200-W-153) was performed using pairs of direct push probe holes. A total of 31 direct-pushes were driven within the TY Tank Farm; 25 of these holes were logged for geophysical parameters and six were driven for the purpose of retrieving vadose zone sediment for characterization and analysis. The samples were collected around tank 241-TY-105, which was estimated to have leaked 35,000 gal of tributyl phosphate (TBP) waste from the uranium recovery process to the vadose zone in 1960 (Wood et al. 2001), and tank 241-TY-106, which was estimated to have leaked 20,000 gal of the TBP-uranium recovery waste to the vadose zone in 1959 . 


\subsubsection{Moisture Content}

Elevated moisture was observed in two of the samples analyzed as part of this study. One of the samples was collected directly south of tank 241-TY-105 (C4624) and the other samples were collected directly south of tank 241-TY-106 (C4604). However, the TY direct samples were collected at the interface between the backfill and Hanford formation; therefore, the elevated moisture measured in these samples could be an artifact of the compaction that occurred at this interface during construction of the tank farm and likely does not indicate the presence of tank-related waste fluids.

\subsubsection{Contamination Profile around tanks 241-TY-105 and 241-TY-106}

Several parameters, including $\mathrm{pH}$, electrical conductivity, nitrate, technetium-99, sodium, and uranium concentrations in water and acid extracts, and direct GEA of sediment samples were used as indicators to determine the subsurface regions contacted by tank waste that presumably leaked from tanks 241-TY-105 and 241-TY-106. The following paragraphs present the highlights from these tests.

The first parameter measured was the $\mathrm{pH}$ of water extracts of the vadose zone sediment. Based on the assumption that tank-related waste fluids are generally caustic and often very caustic ( $>1 \mathrm{M}$ free hydroxide), elevated $\mathrm{pH}$ profiles should be indicative of the near-field region close to the source where the caustic fluid entered the sediments. Nearly all of the samples tested had $\mathrm{pH}$ values in the normal range for Hanford sediments (between 7.5 and 8.5). In fact, only one sample (S06001-1A) collected from probe hole $\mathrm{C} 4604$ contained slightly elevated soil $\mathrm{pH}$ of 8.63 . While a soil $\mathrm{pH}$ of 8.63 is clearly elevated, it is not indicative of a major tank waste impact zone. Vadose zone sediments collected in close proximity to tank waste discharge points typically have soil pHs well above 9 . Therefore, it does not appear that these samples were collected from a location close in proximity to where waste from tank 241-TY-106 entered the vadose zone.

The second parameter that was assessed to investigate proposed tank leaks was the dilution-corrected water extract electrical conductivity (EC) of the sediment samples. The pore water-corrected EC data for all of the samples were dilute and varied little, with a range of 1.71 to $4.62 \mathrm{mS} / \mathrm{cm}$. Based on this, it appears that 1) there is little indication of residual tank waste in the sediments analyzed as part of this study based on elevated dissolved salts and 2) sufficient recharge has likely occurred to drive the bulk of the contamination deeper into the vadose zone. The latter possibility could be evaluated if deeper vadose zone samples were collected.

The third parameter that was used to investigate the extent of tank waste-related contamination in the vadose zone was sodium. Sodium was the dominant water-extractable cation in four out of the five probe holes analyzed (all but probe hole C4604). In the case of probe hole C4604, it is surprising to see a slightly elevated soil $\mathrm{pH}$ while still maintaining calcium as the dominant water-extractable cation. Again, this could be an artifact of the sampling technique and the associated poor sample recovery. For the remaining samples, the fact that they did not contain calcium as the dominant cation indicates that the samples have been impacted by a sodium-bearing waste fluid. The source(s) appears to be a moderately concentrated sodium-bearing waste solution that has displaced the natural divalent cations from the sediment cation exchange sites in the sediments. The TBP waste composition that leaked from tanks TY-105 and TY-106 are estimated to contain $4 \mathrm{M}$ sodium, which is adequately high to be readily observed in vadose zone pore waters. The pore water sodium concentrations in the direct push sediment samples is not as high as would be expected if the sediments were significantly contacted with TBP 
waste. Thus, the sample locations do not appear to be in the region where most of the leaked fluids percolated. The total vertical extent of the ion exchange front is unknown due to the lack of sediment samples from deeper in the vadose zone.

Mobile constituents, such as water-extractable uranium, technetium-99, and nitrate, are three additional parameters that can be used to investigate subsurface contamination. Naturally occurring uranium is present in a crystalline form that is very recalcitrant to leaching. Therefore, elevated amounts of uranium in the 1:1 sediment:water extracts are typically indicative of contaminant uranium.

Technetium-99 and nitrate are both considered highly mobile in the subsurface; therefore, their presence in samples can often be used to estimate the total extent of contaminant plume migration. Of the twelve samples analyzed as part of this study, only one of them contained marginally elevated water-extractable uranium. This sample, which was collected from the shoe at probe hole C4604, contained approximately seven times more uranium (7.20E-03 $\mu \mathrm{g} / \mathrm{g}$ ) than the background borehole (299-W10-27). The sample collected directly shallower, S06001-1A, did not contain a quantifiable amount of water-extractable uranium. Therefore, the uranium present in the shoe material from probe hole $\mathrm{C} 4604$ may be natural uranium that has been leached from the shallower sediment and pushed deeper into the vadose zone. An alternate hypothesis is that the uranium present in this sample was tank related and has been incorporated into soluble calcite precipitates. Quantifiable concentrations of technetium-99 were not measured in any of the TY direct push samples. The relative technetium-99 detection limit for the extraction and analysis of these samples was approximately $0.17 \mathrm{pCi} / \mathrm{g}$. Although the water-extractable nitrate values measured in the TY direct push samples were in general higher than the average water-extractable nitrate from borehole 299-W10-27 (1.51 $\mathrm{g} / \mathrm{g})$, significantly elevated concentrations of nitrate were not measured. The highest water-extractable nitrate concentration measured $(6.15 \mu \mathrm{g} / \mathrm{g})$ was in the shoe material from probe hole $\mathrm{C} 4606$. While this sample was elevated with respect to the background borehole, it contained significantly less nitrate than the highest concentration samples from boreholes C3830 (near TX-105), C3831 (near TX-107), and C3832 (near TX-104), which contained 84.1, 847, and $97.4 \mu \mathrm{g} / \mathrm{g}$ nitrate, respectively.

The final indicator used to define the presence of tank-related waste in these samples was direct measurement of sediments for gamma-emitting radionuclides. Only the fission product isotope cesium137 was detected during gamma analysis of the samples, and it was only observed in one (C4604) of the five direct push sample sets. The shoe material from probe hole $\mathrm{C} 4604$ contained $1.5 \mathrm{pCi} / \mathrm{g}$ cesium-137, while the A-sleeve sample contained $0.6 \mathrm{pCi} / \mathrm{g}$ cesium-137. The A-sleeve sediment from probe hole C4604 was the only sample with an elevated soil pH. Based on this, it seems likely that the slightly elevated $\mathrm{pH}$ in this sample, coupled with the cesium-137 contamination, is a result of contamination from a tank-related waste source. The most probable source of the contamination is the proposed leak from tank 241-TY-106.

\subsubsection{Source of Contamination around Tanks 241-TY-105 and 241-TY-106}

After evaluating all the characterization and analytical data, there is no question that the vadose zone surrounding tank 241-TY-106 has been contaminated by tank-related waste; however, the concentrations of waste constituents found are generally very low, suggesting that the sample locations are not near the bulk of the waste fluid released. The direct observance of elevated soil $\mathrm{pH}$ and cesium-137 in close proximity to tank 241-TY-106 indicates that the tank or infrastructure associated with the tank is responsible for the contamination. The poor recovery associated with the direct push technique has made it difficult to estimate the lateral spread of the contamination, while the nature of the direct push technique 
has made it impossible to discuss the vertical extent of the contamination. However, based on characterization of the three probe holes that were emplaced south of tank 241-TY-106, it does not appear that a significant amount of lateral migration has occurred at the depth sampled. Interpretation of the water extract data associated with these samples suggests that the mobile constituents associated with this leak event reside deeper in the vadose zone at this location; however, the lack of depth discrete samples does not enable the confirmation of this hypothesis.

The vadose zone south tank 241-TY-105 has also been affected by a tank-related waste solution. The presence of sodium as the dominant water-extractable cation indicates that a high sodium-bearing waste stream has created a cation exchange front in this region that has pushed the naturally present divalent cations (calcium and magnesium) off the surface exchange sites. The lack of 1) elevated soil $\mathrm{pH}$ or 2) direct measurement of gamma-emitting radionuclides indicates that the point source of contamination is not in the direct vicinity of the only probe hole emplaced near tank 241-TY-105. The lack of direct evidence of a point source waste signature near tank 241-TY-105 does not mean the tank did not leak; rather, the vadose zone sample set collected as part of this investigation was not sufficient to either confirm or rebut the supposition that a leak from tank 241-TY-105 led to UPR 200-W-152.

\subsection{T Tank Farm Characterization Activities and Data}

The next several sections summarize geochemical and physical characterization data collected on sediment from the direct push holes emplaced within the T Tank Farm. Again, these characterization activities emphasized tests that provided basic characterization data and were fundamental to determining the distribution of mobile contaminants in the vadose zone sediments. Such information on the direct push sediments included moisture content, total and inorganic carbon content, $\mathrm{pH}$, electrical conductivity (EC), and measurements of major cations, anions, and trace metals (including technetium-99 and uranium-238) in 1:1 sediment:water and measurement of major cations, anions, and trace metals (including technetium-99 and uranium-238) in $8 \mathrm{M}$ nitric acid extracts. Gamma energy analysis (GEA) of the sediments was also performed to search for any detectable man-made gamma-emitting radionuclides.

\subsubsection{Sampling Summary at the T Tank Farm}

A geochemical investigation in the vicinity of tanks 241-T-101 and 241-T-104 was performed using pairs of direct push probe holes. A total of 19 direct-pushes were driven within the T Tank Farm; 14 of these holes were logged for gross gamma using calibrated probes and five were driven for the purpose of retrieving vadose zone sediment for characterization and analysis. The samples were collected around tank 241-T-101, which was estimated to have leaked 7,500 gal of REDOX cladding waste to the vadose zone in 1992.

\subsubsection{Moisture Content}

Elevated moisture was observed in several of the samples analyzed as part of this study. The average gravimetric moisture content of all of the samples measured in this study was $7.9 \mathrm{wt} \%$, which was slightly higher than the average moisture content in core samples collected within the Hanford formation $\mathrm{H} 2$ unit (3.9\%) at the nearby TX Tank Farm characterization site (background borehole 299-W10-27 just east of the TY Tank Farm). However, the Cold Creek Unit was intercepted by several of the T Tank Farm direct push samples, which caused the average moisture content for all of the samples to be biased high when compared to the coarse-grained materials comprising the Hanford formation $\mathrm{H} 2$ unit. Therefore, the 
elevated moisture measured in these samples was an artifact of the stratigraphic unit (the Cold Creek unit) encountered and does not necessarily indicate the presence of tank-related waste fluids.

\subsubsection{Contamination Profile around Tank 241-T-101}

Several parameters, including $\mathrm{pH}$, electrical conductivity, nitrate, technetium-99, sodium, and uranium concentrations in water and acid extracts, and direct GEA of sediment samples were used as indicators to determine the subsurface regions contacted by tank waste that presumably leaked from tank 241-T-101. The following paragraphs present the highlights from these tests.

The first parameter measured was the $\mathrm{pH}$ of water extracts of the vadose zone sediment. Based on the assumption that tank-related waste fluids are generally caustic and often very caustic ( $>1 \mathrm{M}$ free hydroxide), elevated $\mathrm{pH}$ profiles should be indicative of the near-field region close to the source where the caustic fluid entered the sediments. Nearly one-third of the samples tested had $\mathrm{pH}$ values above the normal range for Hanford sediments $(>8.5)$. The sediments characterized as having an elevated $\mathrm{pH}$ were collected from probe holes C4598, C4596, and C5378 at depths ranging from approximately 43 to $63 \mathrm{ft}$ bgs. As mentioned previously, vadose zone sediments collected in close proximity to tank waste discharge points typically have soil pHs well above 9 . The three probe holes containing sediments with an elevated $\mathrm{pH}$ were the three sample probe holes emplaced closest to tank 241-T-101. Therefore, it appears that waste released from tank 241-T-101 migrated to the southeast in this region of the vadose zone.

The second parameter that was assessed to investigate the proposed tank leak was the dilutioncorrected water extract electrical conductivity (EC) of the sediment samples. The pore water-corrected EC data for many of the samples ranged from dilute $(1.26 \mathrm{mS} / \mathrm{cm})$ to mildly saline $(21.1 \mathrm{mS} / \mathrm{cm})$. All of the samples that exhibited elevated sediment $\mathrm{pHs}$ also had elevated porewater conductivities. Not surprisingly, the samples with the highest porewater-corrected conductivities were collected from probe hole C4598, which was the closest sampling hole in proximity to tank 241-T-101. The next highest conductivity was found in samples from probe hole C5378, which was located approximately $5 \mathrm{~m}$ to the southeast of tank 241-T-101. These samples were collected at a depth of approximately $63 \mathrm{ft} \mathrm{bgs,} \mathrm{which}$ was $20 \mathrm{ft}$ deeper than the depth of the $\mathrm{C} 4598$ samples. These results again indicate that the initial impact zone from waste released from tank 241-T-101 migrated to the southeast of the tank to at least the location intercepted by probe hole C5378.

The third parameter that was used to investigate the extent of tank waste-related contamination in the vadose zone was sodium. Sodium was the dominant water-extractable cation in all but one of the sample strings (all of the samples except those from probe hole C5374). All three cores from probe hole C5374 contained elevated concentrations of calcium, potassium, magnesium, strontium, and sodium. It was surprising to find elevated calcium, magnesium, and sodium together in the same sample, since the sodium would typically drive the divalent cations off the exchange sites; this phenomenon could indicate that the samples were collected near the leading edge of the ion exchange front. However, it is impossible to confirm this hypothesis given the lack of sample coverage (particularly with respect to depth) in the area.

Water-extractable technetium-99 was found in most of the direct push core samples analyzed; however, it was only significantly elevated in the sediments collected from probe hole C5374. Not surprisingly, these were some of the deepest direct push samples collected as part of the T Tank Farm 
sampling campaign. Technetium-99 is generally considered quite mobile in the subsurface, and as such, peak concentrations in the vadose zone are often found well below $115 \mathrm{ft}$ bgs in regions that have been contaminated by tank loss events. Water-leachable uranium-238 was all less than $0.2 \mu \mathrm{g} / \mathrm{g}$, indicating that there was not a significant amount of contaminant uranium in the vadose zone at these sampling locations. This is compatible with the fact that Tank T-101 released less than a kg of uranium. Waterextractable nitrate was significantly elevated (in excess of $250 \mu \mathrm{g} / \mathrm{g}$ ) in the string of cores collected from probe hole C5374 from approximately $80 \mathrm{ft}$ bgs. Probe hole C5374 was emplaced to the south of tank 241-T-101 and adjacent to tank 241-T-104. It is obvious that tank waste has impacted the vadose zone at this location; however, this single set of data does not permit the source of the contamination to be identified.

The final indicator species used to define the presence of tank-related waste in the T direct push samples was direct measurement of sediments for gamma-emitting radionuclides. Direct measurement of sediment samples for gamma-emitting radionuclides showed that the sediments contained natural potassium-40, the activation product cobalt-60, and the fission product isotopes cesium-137, europium152, europium-154, and europium-155. The samples that contained the manmade gamma-emitting radionuclides were from the four probe holes emplaced closest to tank 241-T-101. Significantly lower activities of gamma-emitting radionuclides were found at these locations than from the previous characterization study performed in the T Tank Farm (Serne et al. 2004b). As much as $40 \mathrm{pCi} / \mathrm{g}$ cesium137 was measured by Serne et al. (2004b) in borehole C4104, while the peak activity measured as part of this study was $16.8 \mathrm{pCi} / \mathrm{g}$. Given the mixed depth sampling frequency that was performed during the direct push campaign, it is difficult to say anything about the relative mobility of the radionuclides; however, it appears that they may have migrated southeast from tank 241-T-101.

\subsubsection{Tier II Activites Associated with the T Tank Farm Direct Push Samples}

Tier II characterization activities were performed on a subset of the T Tank Farm direct push samples to 1) further investigate the discrepancy between water-extractable and acid-leachable technetium-99 in the direct push samples, 2) see if ruthenium isotopic analyses could be used to identify contaminant source terms, and 3) see if chloride data generated during the 1:1 sediment:water extraction process could be used to investigate the effect of the tank drip line on recharge. Summaries of the results from Tier II tests and analyses are presented in the following sections.

\subsubsection{Total Extractable Technetium-99}

Extraction of technetium-99 from vadose zone sediments using deionized water, $8 \mathrm{M} \mathrm{HNO}_{3}$, and microwave-assisted digestion provided mixed results. The \%RSDs for the 1:1 sediment:water extract samples that were not resin-treated were excellent, with a range from $0.759 \%$ to $2.30 \%$ based on one standard deviation of samples analyzed in triplicate. The total technetium- 99 analyzed in these samples compared quite well with the total technetium-99 measured in resin-treated sample aliquots. Relative differences between the two data sets for average concentrations of the samples from probe hole C5374 (as measured via the three replicate samples) ranged from $1.42 \%$ to $9.97 \%$. These results indicate that technetium-99 reported in the 1:1 sediment:water extracts is indeed technetium-99 (i.e., a matrix interference is not present in these samples). These results show that the additional step of treating the samples with TEVA ${ }^{\circledR}$ resin is not necessary when quantifying technetium- 99 in water extract samples. 
The \%RSDs for the $8 \mathrm{M}$ nitric acid extract samples that were not resin-treated were acceptable, although they weren't as good as those for the water extract samples. For the three sample sets that contained technetium-99 in excess of the limit of quantification for analysis, the \%RSDs ranged from $6.39 \%$ to $12.5 \%$. Spike recoveries performed as quality control for this data set worked quite well. All three spikes, the blank spike, the background sediment matrix spike, and the direct push sample matrix spike all had recoveries in excess of $85 \%$. These results indicate that technetium-99 is stable throughout the $8 \mathrm{M}$ nitric acid extraction process. The $\%$ RSDs for the $8 \mathrm{M}$ nitric acid extract samples that were treated with TEVA ${ }^{\circledR}$ resin were slightly better than those for the non-treated samples. For the three sample sets that contained technetium-99 in excess of the limit of quantification for analysis, the \%RSDs ranged from $3.44 \%$ to $12.9 \%$. Unfortunately, spike recoveries for the aliquots of samples that were treated with the resin were quite variable and inadequately low. None of the TEVA ${ }^{\circledR}$ resin-treated spikes had recoveries of $85 \%$ or greater. These low recoveries clearly indicate that technetium-99 was lost between the $8 \mathrm{M}$ nitric acid extraction step and analysis of the resin-treated eluents. The two most probable steps that could have led to a deficiency in technetium-99 recoveries were heating of the samples to dryness once the $8 \mathrm{M}$ nitric acid extracts were complete (this step was performed to change the sample matrix prior to its addition to the TEVA columns), or fouling of the resin columns by the high concentrations of dissolved solids in the acid extract samples.

Although there were issues with the total recovery of technetium-99 through the resin treatment process, the results of this test do allow for some qualifications to be made to the Tier II acid extract data (and subsequently to the Tier I acid extract data). Comparison of the non-resin-treated sample data with the resin-treated data showed good agreement between the analyses. Relative differences between the two data sets for average concentrations of the samples from probe hole C5374 (as measured via the three replicate samples) ranged from $10.3 \%$ to $13.3 \%$ (the technetium-99 concentrations in the resin-treated samples were consistently lower than those in the untreated samples). There was exceptionally good agreement between the data sets given the low total recoveries measured after resin treatment of the samples. Additionally, it appears that a matrix effect is not the cause of the elevated technetium-99 in the acid extracts vs. the water extracts. These results imply that some credence should be given to the $8 \mathrm{M}$ acid extract technetium-99 data. However, before quantitative results are provided, the $8 \mathrm{M}$ nitric acid extracts should be taken through the resin treatment process again after the addition of a tracer to monitor recoveries through the purification steps.

The \%RSDs for the microwave digests that were not resin-treated were not acceptable, given that technetium-99 was not measured above the limit of quantification for the analysis. Microwave digestion generates greater sample dilution due to a higher solution to solid ratio (100:1 vs. approximately 6:1 for the nitric acid extracts and 1:1 for the sediment:water extracts). On a positive note, spike recoveries performed as quality control for this data set worked quite well. All three spikes - the blank spike, the background sediment matrix spike, and the direct push sample matrix spike- had recoveries in excess of $85 \%$. These results indicate that technetium-99 is stable throughout the microwave digestion process, but higher sample concentrations are necessary to alleviate detection limit issues associated with the technique.

Treatment of the microwave-digested samples with TEVA® resin resulted in quantitative technetium99 data for all of the direct push samples from probe hole C5374. However, the \%RSDs for the microwave-digested samples varied considerably. The \%RSDs for the four direct push sample sets ranged from $15.5 \%$ to $63.2 \%$. Spike recoveries for the aliquots of sample that were treated with the resin were sporadic. Only one of the TEVA ${ }^{\circledR}$ resin-treated spikes (the background matrix spike) had a recovery 
of greater than $85 \%$. As with the acid extract data, these results clearly indicate that technetium-99 was lost between the microwave digestion step and analysis of the resin-treated samples. The same two steps that could have led to a deficiency in technetium-99 recoveries in the $8 \mathrm{M}$ nitric acid extracts were the primary culprits with these samples as well.

Although there were issues with the total recovery of technetium-99 with the acid and microwave digestion data sets and no direct method of assuring that all the technetium-99 present in the sediment was water extractable is data set, these results can be used to qualitatively assess the thoroughness of the Tier I water and acid extraction techniques. Comparison of the resin-treated microwave-assisted digestion data to the water and acid extract results shows that significantly more technetium-99 can be extracted via nitric acid or with the aid of microwave digestion than was released using water as the leachant. For example, the two Tier II water extraction tests leached an average of $2.23 \mathrm{E}-03 \mu \mathrm{g} / \mathrm{g}$ technetium-99 from samples B1KC40C. These results were approximately a factor of two higher than the amount leached from this sample material during Tier I testing of the direct push samples. Comparatively, 7.91E-03 $\mu \mathrm{g} / \mathrm{g}$ technetium-99 was acid leached from this sample during Tier I testing. Tier II acid extraction of this sample resulted in 5.93E- $03 \mu \mathrm{g} / \mathrm{g}$ and $5.34 \mathrm{E}-03 \mu \mathrm{g} / \mathrm{g}$ technetium-99 in the non-treated and resin-treated samples, respectively. Additionally, the resin-treated technetium-99 could be biased low due to loss of technetium through the treatment process. Finally, resin-treated microwave digests of this sample resulted in an average technetium-99 concentration of $6.76 \mathrm{E}-03 \mu \mathrm{g} / \mathrm{g}$. Again, this result could be biased low due to loss of technetium-99 through the purification process. It is difficult to assign quantitative numbers to the Tier II resin-treated acid extract and microwave digest data given the poor recoveries and less-than-optimal reproducibility of the data. However, given that large discrepancies in total technetium99 concentrations amongst the various extraction techniques (with water extraction consistently being lowest) still existed after resin treatment of the acid extracts and microwave digests, serious thought must be given to the validity of using water-extractable technetium- 99 data as the basis for determining total technetium-99 in the sediments.

\subsubsection{Analysis of Isotopic Ruthenium}

Several samples from borehole C4104 (emplaced near tank 241-T-106) (Serne et al. 2004b) were processed in conjunction with sediments from probe hole C5374 and analyzed for stable ruthenium isotopes via ICP-MS. The data were plotted as the isotopic ratios of ruthenium-102:ruthenium-104 vs. ruthenium-101:ruthenium-104. All of the sediment extract data analyzed plot on or near the mixing line between uranium-235 fission and plutonium-239 fission. Further, there appears to be two discrete "groups" of isotopic ratios associated with this data set. The upper group (a cluster of data points closer to the U-235 fission end member) consists primarily of sediment samples collected from borehole C4104 at depths of approximately 76 and $81 \mathrm{ft}$ bgs. These specific samples from borehole $\mathrm{C} 4104$ were chosen for comparison because they bracket the depth of the T Tank Farm direct push samples processed and intercept the same stratigraphic unit (the Cold Creek Unit). The lower group (a cluster of data points closer to the Pu-239 fission end member) contains all of the samples from probe hole C5374 that met the reporting criteria (which were only the $8 \mathrm{M} \mathrm{HNO}_{3}$ column elutions), as well as one of the $8 \mathrm{M} \mathrm{HNO}_{3}$ column elutions from the $\mathrm{C} 4104$ borehole sample collected at $76 \mathrm{ft}$ bgs. Earlier preliminary data indicated that a mass interferent or matrix effect could be biasing the isotopic ratio low (i.e. towards the plutonium-239 fission end member). However, results from these tests indicate that the isotopic ratios measured in the lower cluster of data have not been biased low due to matrix interferences caused by the $8 \mathrm{M} \mathrm{HNO}_{3}$, suggesting that the isotopic differences measured between the two data clusters could represent isotopic ruthenium from different waste source terms. 
Given that there were some analytical shortcomings/challenges associated with this dataset, it is difficult to interpret the results with a high degree of confidence. However, based on the data, it does appear that multiple source terms (at least two) could be present in the C4104 borehole at the interface of the Hanford formation and the Cold Creek Unit. Additionally, one of the sources present at this location has a similar ruthenium isotopic ratio to those measured in the direct push samples collected from probe hole C5374. Since these samples were all collected at the interface of the Hanford formation and the Cold Creek Unit, it is possible that waste from the 241-T-101 tank leak migrated laterally to the southwest and can be observed in the C4104 borehole (Serne et al. [2004b] showed that the strata dip to the southwest in the T Tank Farm). Again, it is difficult to place an exact level of confidence on the interpretation of this data; however, it is supported by the stratigraphy in the area and certainly warrants further investigation.

\subsubsection{Recharge Estimates}

The existing chloride data from the pushes at the $\mathrm{T}$ Tank Farm were unsatisfactory for use in estimating recharge using the chloride mass balance (CMB) method. Part of what makes the data problematic for $\mathrm{CMB}$ is that the chloride profile is incomplete with much of the data being between 43 and $50 \mathrm{ft}$ bgs. Without some knowledge about the chloride profile over a much larger depth interval, it can't be said if the chloride concentrations represent steady-state conditions, whether other transport processes are dominating (i.e., preferential flow), and if the chloride concentrations represent past or current recharge conditions.

\subsubsection{Source of Contamination around tanks 241-T-101 and 241-T-104}

After evaluating all the characterization and analytical data, there is no question that the vadose zone in the vicinity of tank 241-T-101 has been contaminated by tank-related waste. The direct observance of elevated soil $\mathrm{pH}$, porewater-corrected electrical conductivity, nitrate, technetium-99, elevated water-extractable sodium, and fission product isotopes of europium as well as cesium-137 in close proximity to tank 241-T-101 indicates that the tank or infrastructure associated with the tank is responsible for the contamination. The sparse sample coverage associated with the direct push technique has made it difficult to estimate the lateral spread of the contamination, while the depth limitation of the direct push technique has made it impossible to discuss the vertical extent of the contamination. However, based on characterization of the probe holes that were emplaced to the southeast of tank 241-T-101, it appears that waste from tank 241-T-101 migrated laterally several meters away from the tank. Interpretation of the water extract data associated with these samples indicates that the mobile constituents associated with this leak event reside deeper in the vadose zone at this location; however, the lack of depth-discrete samples does not enable the confirmation of this hypothesis.

The vadose zone directly northeast of tank 241-T-104 also has been found to be contaminated with

tank waste constituents. It is not possible at this time to directly attribute the source of this contamination to a particular tank. Sufficient data does not exist to determine if the contamination observed in this region is a result of a loss from tank 241-T-104 or if it is a result of lateral spreading from tank 241-T-101. 


\subsection{Detailed Characterization to Elucidate Controlling Geochemical Processes at the T and TY Tank Farms}

Characterization activities of the direct push samples added some insight as to 1) the processes that control the observed distribution of contaminants and 2) the migration potential of key contaminants in the future. The pore waters, calculated by dilution correction of the 1:1 water extracts in the sediment from the direct push samples, were dominated by sodium and bicarbonate for sediments with obvious signs of tank fluids. The most concentrated pore water is shown in Table 5.1 in units of meq/L. Also included in the table for comparison are the maximum pore water concentrations found in other characterization work previously reported for the T, TX, and SX Tank Farms.

For the TY Tank Farm direct push samples, the most saline calculated pore water resided in the H2 unit and had a chemical composition of $80.5 \mathrm{meq} / \mathrm{L}$ calcium, $67.2 \mathrm{meq} / \mathrm{L}$ sodium, $10.6 \mathrm{meq} / \mathrm{L}$ potassium, and trace amounts of magnesium $(0.02 \mathrm{meq} / \mathrm{L})$. The cations were balanced primarily by bicarbonate $(113 \mathrm{meq} / \mathrm{L})$, with lesser amounts of sulfate $(38.6 \mathrm{meq} / \mathrm{L})$, chloride $(2.12 \mathrm{meq} / \mathrm{L})$, nitrate $(0.999 \mathrm{meq} / \mathrm{L})$, and phosphate $(0.422 \mathrm{meq} / \mathrm{L})$. As shown in Table 5.1, the most concentrated calculated pore water from the TY Tank Farm direct push sampling campaign was less concentrated, and in some cases much less concentrated, than pore waters found in the vadose zone sediments from the T, TX, or SX Tank Farms.

For the T Tank Farm direct push samples, the most saline calculated pore water also resided in the $\mathrm{H} 2$ unit and had a chemical composition of $193 \mathrm{meq} / \mathrm{L}$ sodium with a trace amount of calcium $(0.576 \mathrm{meq} / \mathrm{L})$. The cations were balanced almost exclusively by bicarbonate $(192 \mathrm{meq} / \mathrm{L})$, with lesser amounts of sulfate (3.05 meq/L), nitrate $(1.82 \mathrm{meq} / \mathrm{L})$, and phosphate $(1.65 \mathrm{meq} / \mathrm{L})$.

The distribution of the water-extractable major cations in the direct push sediment samples indicates that an ion-exchange process dominates the pore water/sediment interactions where tank fluid has passed by or currently exists. The depth profiles for the divalent alkaline earth cations (calcium, magnesium, and strontium) versus sodium show depleted alkaline earth cation concentrations in the shallow Hanford formation sediments at both locations to depths of up to $80 \mathrm{ft}$ bgs (the terminal depth of the deepest sample emplaced as part of the characterization campaign). Conversely, the water-extractable sodium concentrations in these zones were elevated. These trends suggest that tank fluids that are high in sodium are present at these locations. The lack of a significant amount of nitrate in the TY Tank Farm direct push holes indicates that the contamination has been present for a sufficiently long period of time to facilitate the migration of more mobile contaminants (i.e., nitrate and technetium-99) deeper into the vadose zone. The observance of significantly elevated nitrate in the deepest direct push samples collected as part of the $\mathrm{T}$ Tank Farm campaign further supports the premise that mobile contaminants reside much deeper in the vadose zone at both of these locations. 
Table 5.1. Maximum Pore Water Concentrations in Sediments from the Hanford Formation Unit (reported in units of $\mathrm{mN}$ )

\begin{tabular}{|c|c|c|c|c|c|c|c|}
\hline \multirow{2}{*}{ Tank } & \multicolumn{7}{|c|}{ Closest Single-Shell Tank and Borehole or Borehole Number } \\
\hline & TY-106 & T-101 & TX-107 & T-106 & SX-115 & SX-109 & SX-108 \\
\hline \begin{tabular}{|l|} 
Borehole/Probe Hole \\
\end{tabular} & $\mathrm{C} 4604$ & C4598 & C3831 & C4104 & W23-19 & 41-09-39 & W23-64 \\
\hline $\mathrm{Na}$ & 67.2 & 193 & 418 & 150 & 35.6 & 6066 & 16900 \\
\hline $\mathrm{Ca}$ & 80.5 & 0.576 & 1.2 & 0.7 & 281 & 619 & 90 \\
\hline $\mathrm{Mg}$ & 0.02 & 0 & 0.2 & 0.6 & 94.6 & 24 & 10 \\
\hline $\mathrm{K}$ & 10.6 & 0 & 4.7 & 1.2 & 3.6 & 42 & 92 \\
\hline $\mathrm{Sr}$ & 0 & 0 & 0 & 0 & 1.5 & 4.4 & 1 \\
\hline $\mathrm{UO}_{2}$ & 0 & 0 & 0 & 0 & 0 & 0 & 0 \\
\hline Total Cations & 158 & 194 & 424 & 153 & 416 & 6755 & 17093 \\
\hline $\mathrm{NO}_{3}$ & 0.999 & 1.82 & 202 & 9.2 & 420 & 6710 & 15677 \\
\hline $\mathrm{NO}_{2}$ & 0 & 0 & 0 & 0 & 0 & 28 & 32 \\
\hline $\mathrm{SO}_{4}$ & 38.6 & 3.05 & 15.2 & 5.6 & 3.3 & 95 & 500 \\
\hline $\mathrm{CrO}_{4}$ & 0 & 0 & 0 & 0 & 100 & 0 & 0 \\
\hline $\mathrm{PO}_{4}$ & 0.422 & 1.65 & 8.4 & 1.8 & 0 & 0 & 0 \\
\hline $\mathrm{Cl}$ & 2.12 & 0 & 6.4 & 3.0 & 6 & 119 & 147 \\
\hline $\mathrm{F}$ & 0.635 & 0 & 0.8 & 6.4 & 0 & 0 & 0 \\
\hline $\mathrm{HCO}_{3} / \mathrm{CO}_{3}$ & 113 & 192 & 191 & $220 *$ & 7 & 0 & 666 \\
\hline Total Anions & 155 & 199 & 424 & $246^{*}$ & 536 & 6952 & 17022 \\
\hline $\begin{array}{l}\text { Dilution Corrected EC } \\
(\mathrm{mS} / \mathrm{cm})\end{array}$ & 3.12 & 21.1 & 43.3 & 24.3 & 33.1 & 524 & 1772 \\
\hline
\end{tabular}





\subsection{Interim Measures Support}

Two sets of direct push samples were delivered to the laboratory for rapid turnaround analysis of key constituents. The samples were collected north of the T Tank Farm using the direct push sampling technique; Table 6.1 contains a list of the samples. All eight samples were broken down in the laboratory, characterized by a geologist, digitally photographed, and processed for moisture content. Upon completion of the sample break-down activities, one sample from each probe hole was processed using the 1:1 sediment:water extraction technique described in Section 3.3.2 and analyzed for technetium-99 and nitrate. Results of these analyses, as well as all of the information gathered during sample breakdown, were provided to CH2M HILL Hanford Group, Inc. within 24 hours of receipt of the last sample by the laboratory. Photographs of the samples are contained in Appendix E and geological logs of the samples are presented in Appendix F. Results of the moisture content analysis of select samples from each probe hole are presented in Table 6.2. The 1:1 sediment:water extract nitrate and technetium-99 data are contained in Tables 6.3 and 6.4, respectively.

Table 6.1. Sample Inventory from the T Tank Farm Interim Measures Samples

\begin{tabular}{|l|c|l|c||}
\hline $\begin{array}{c}\text { Sample } \\
\text { Number }\end{array}$ & $\begin{array}{c}\text { Probe Hole } \\
\text { Number }\end{array}$ & $\begin{array}{c}\text { Sample } \\
\text { Number }\end{array}$ & $\begin{array}{c}\text { Probe Hole } \\
\text { Number }\end{array}$ \\
\hline \hline B1NP87C & C5692 & B1NP90C & C5694 \\
\hline B1NP87B & C5692 & B1NP90B & C5694 \\
\hline B1NP87A & C5692 & B1NP90A & C5694 \\
\hline B1NP87 & C5692 & B1NP90 & C5694 \\
\hline \multicolumn{2}{|l|}{ Shaded cells indicate grab samples. } \\
\hline
\end{tabular}

Table 6.2. Gravimetric Moisture Content of Samples Obtained from the T Tank Farm Interim Measures Activites

\begin{tabular}{||l|c|c|c||}
\hline $\begin{array}{c}\text { Sample } \\
\text { ID }\end{array}$ & $\begin{array}{c}\text { Probe Hole } \\
\text { ID }\end{array}$ & $\begin{array}{c}\text { Mid-Depth } \\
\mathrm{ft} \text { bgs }\end{array}$ & $\begin{array}{c}\text { Moisture } \\
(\%)\end{array}$ \\
\hline \hline B1NP87C & C5692 & 45.75 & $4.11 \%$ \\
\hline B1NP87B & C5692 & 46.25 & $4.68 \%$ \\
\hline B1NP87A & C5692 & 46.75 & $7.41 \%$ \\
\hline B1NP87 & C5692 & 47.25 & $4.25 \%$ \\
\hline B1NP90C & C4624 & 53.25 & $4.94 \%$ \\
\hline B1NP90B & C4610 & 53.75 & $6.96 \%$ \\
\hline B1NP90A & C4610 & 54.25 & $8.58 \%$ \\
\hline B1NP90 & C4606 & 54.75 & $4.88 \%$ \\
\hline Shaded cells indicate grab samples. \\
\hline
\end{tabular}

Table 6.3. Sediment:Water-Extractable Nitrate Data for Samples Obtained from the T Tank Farm Interim Measures Activities

\begin{tabular}{||l|c|c|c||}
\hline $\begin{array}{c}\text { Sample } \\
\text { ID }\end{array}$ & $\begin{array}{c}\text { Probe Hole } \\
\text { ID }\end{array}$ & $\begin{array}{c}\text { Mid-Depth } \\
\mathrm{ft} \text { bgs }\end{array}$ & $\begin{array}{c}\text { Nitrate } \\
(\mu \mathrm{g} / \mathrm{g})\end{array}$ \\
\hline \hline B1NP87A & C5692 & 46.75 & $2.56 \mathrm{E}+00$ \\
\hline B1NP90A & C4610 & 54.25 & $1.26 \mathrm{E}+00$ \\
\hline $\begin{array}{l}\text { The values for nitrate are considered estimates. The measured value for nitrate in the analytical } \\
\text { preparation blank was greater than 5\% of the concentration measured in the sample. }\end{array}$ \\
\hline
\end{tabular}


Table 6.4. 1:1 Sediment:Water-Extractable Technetium-99 Data for Samples Obtained from the T Tank Farm Interim Measures Activities

\begin{tabular}{||c|c|c|c||}
\hline $\begin{array}{c}\text { Sample } \\
\text { ID }\end{array}$ & $\begin{array}{c}\text { Probe Hole } \\
\text { ID }\end{array}$ & $\begin{array}{c}\text { Mid-Depth } \\
\text { ft bgs }\end{array}$ & $\begin{array}{c}\text { Technetium-99 } \\
\text { (pCi/g) }\end{array}$ \\
\hline \hline B1NP87A & C5692 & 46.75 & $<3.56 \mathrm{E}-01$ \\
\hline B1NP90A & C4610 & 54.25 & $<3.66 \mathrm{E}-01$ \\
\hline Less than symbol indicates the instrument returned a negative value. \\
\hline
\end{tabular}




\subsection{References}

American Society for Testing and Materials (ASTM) D2216-98. 1998. Test Method for Laboratory Determination of Water (Moisture) Content of Soil and Rock by Mass. American Society for Testing and Materials, West Conshohocken, Pennsylvania.

American Society for Testing and Materials (ASTM) D2488-93. 1993. Standard Practice for Description and Identification of Soils (Visual-Manual Procedure). American Society for Testing and Materials, West Conshohocken, Pennsylvania.

American Society for Testing and Materials (ASTM) E1915-01. 2001. Standard Test Methods for Analysis of Metal Bearing Ores and Related Materials by Combustion Infrared Absorption Spectrometry. American Society for Testing and Materials, West Conshohocken, Pennsylvania.

American Society of Agronomy (ASA). 1996. Methods of Soil Analysis-Part 3, Chemical Methods, SSSA Book Series 5, ed. DL Sparks, Soil Science Society of America, Madison, Wisconsin.

Bjornstad BN. 1984. Suprabasalt Stratigraphy Within and Adjacent to the Reference Repository Location. SD-BWI-DP-039, Rockwell Hanford Operations, Richland, Washington.

Bjornstad BN. 2006. On the Trail of the Ice Age Floods: A Geological Field Guide to the Mid-Columbia Basin, Keokee Co. Publishing, Inc., Sandpoint, Idaho.

Brown CF, RJ Serne, BN Bjornstad, DG Horton, DC Lanigan, RE Clayton, MM Valenta, TS Vickerman, IV Kutynakov, KN Geiszler, SR Baum, KE Parker, and MJ Lindberg. 2006. Characterization of Vadose Zone Sediments Below the C Tank Farm: Borehole C4297 and RCRA Borehole 299-E27-22. PNNL15503, Pacific Northwest National Laboratory, Richland, Washington.

Brown CF, RJ Serne, BN Bjornstad, MM Valenta, DC Lanigan, TS Vickerman, RE Clayton, KN Geiszler, C Iovin, ET Clayton, IV Kutynakov, SR Baum, MJ Lindberg, and RD Orr. 2007. Characterization of Vadose Zone Sediments from C Waste Management Area: Investigation of the C-152 Transfer Line Leak. PNNL-15617, Pacific Northwest National Laboratory, Richland, Washington.

Brown D.J. 1959. Subsurface Geology of the Hanford Separation Areas. HW-61780, General Electric Company, Richland, Washington.

Brown RE. 1970. Interrelationships of Geologic Formations and Processes Affecting Ecology as Exposed at Rattlesnake Springs. BNWL-B-29, Battelle Northwest Laboratory, Richland, Washington.

Cantrell KJ, RJ Serne, JM Zachara, PE Dresel, KM Krupka, and CF Brown. 2007. Geochemistry Data Package for the Vadose Zone in the Single-Shell Tank Waste Management Areas at the Hanford Site. PNNL-16663 (in press), Pacific Northwest National Laboratory, Richland, Washington.

Connelly MP, JV Borghese, CD Delaney, BH Ford, JW Lindberg, and SJ Trent. 1992. Hydrogeologic Model for the 200 East Groundwater Aggregate Area. WHC-SD-EN-TI-019, Westinghouse Hanford Company, Richland, Washington. 
Crumpler JD. 2002. Site Specific SST Phase 1 RFI/CMS Work Plan Addendum for WMAs T and TX-TY. RPP-7578, Rev. 2, CH2M HILL Hanford Group, Inc., Richland, Washington.

EPA Method 300.0A. 1984. Test Method for the Determination of Inorganic Anions in Water by Ion Chromatography. EPA-600/4-84-017, U.S. Environmental Protection Agency, Washington, D.C.

EPA Method 3050B. 2000a. “Acid Digestion of Sediments, Sludges, and Soils.” Test Methods for Evaluating Solid Waste, Physical/Chemical Methods. EPA Publication SW-846 [Online manual]. Available URL: http://www.epa.gov/epaoswer/hazwaste/test/sw846.htm

EPA Method 6010B. 2000b. "Inductively Coupled Plasma-Atomic Emission Spectrometry." Test Methods for Evaluating Solid Waste, Physical/Chemical Methods. EPA Publication SW-846 [Online manual]. Available URL: http://www.epa.gov/epaoswer/hazwaste/test/sw846.htm

EPA Method 6020. 2000c. "Inductively Coupled Plasma-Mass Spectrometry." Test Methods for Evaluating Solid Waste, Physical/Chemical Methods. EPA Publication SW-846 [Online manual]. Available URL: http://www.epa.gov/epaoswer/hazwaste/test/sw846.htm

Folk RL. 1968. Petrology of Sedimentary Rocks. Hemphill, Austin, Texas.

Freeman-Pollard JR, JA Caggiano, and SJ Trent. 1994. Engineering Evaluation of the GAO/RCED-89157, Tank 241-T-106 Vadose Zone Investigation. BHI-00061, Bechtel Hanford Inc., Richland, Washington.

Johnson VG, TE Jones, SP Reidel, and MI Wood. 1999. Subsurface Physical Conditions of the S-SX Waste Management Area. HNF-4936, Lockheed Martin Hanford Corporation, Richland, Washington.

Last GV, BN Bjornstad, MP Bergeron, DW Wallace, DR Newcomer, JA Schramke, MA Chamness, CS Cline, SP Airhart, and JS Wilbur. 1989. Hydrogeology for the 200 Areas Low-Level Burial Grounds An Interim Report. PNL-6820, Pacific Northwest Laboratory, Richland, Washington.

Lindsey KA, MP Connelly, and BN Bjornstad. 1992. Geologic Setting of the 200 West Area - An Update. WHC-SD-EN-TI-008, Westinghouse Hanford Company, Richland, Washington.

Lindsey KA, SE Kos, and KD Reynolds. 2001. Vadose Zone Geology of Boreholes 299-W10-27 and 299-E11-39 T-TX-TY Waste Management Area Hanford Site, South-Central Washington. RPP-8531, CH2M HILL Hanford Group, Inc., Richland, Washington

Myers DA. 2005. Field Investigation Report for Waste Management Areas T and TY. RPP-23752, CH2M HILL Hanford Group, Inc., Richland, Washington.

Pacific Northwest Laboratory (PNL). 1990. Procedures for Groundwater Investigations. PNL-MA-567, Pacific Northwest Laboratory, Richland, Washington.

Pacific Northwest National Laboratory (PNNL). 1997. Gamma Energy Analysis Operation and Instrument Verification Using the Genie2000 ${ }^{T M}$ Support Software. PNNL-RRL-01, Pacific Northwest National Laboratory, Richland, Washington. 
Pacific Northwest National Laboratory (PNNL). 1998. Inductively Coupled Plasma Mass Spectrometric (ICP-MS) Analysis. PNNL-AGG-415, Pacific Northwest National Laboratory, Richland, Washington.

Pacific Northwest National Laboratory (PNNL). 2005. Soil Water Content. PNNL-AGG-WC-001 Rev.0, Pacific Northwest National Laboratory, Richland, Washington.

Price WH and KR Fecht. 1976. Geology of the 241-TY Tank Farm. ARH-LD-137, Atlantic Richfield Hanford Company, Richland, Washington.

Randall R, R Price, and JA Caggiano. 2000. Analysis and summary report of historical dry well gamma logs for 241-T Tank Farm - 200 West. RPP-6088, CH2M HILL Hanford Group, Inc., Richland, Washington.

Reidel SP and KR Fecht. 1994. Geologic Map of Priest Rapids 1:100,000 Quadrangle, Washington. Open-File Report 94-13, Washington Division of Geology and Earth Resources, Washington State Department of Natural Resources, Olympia, Washington.

Reidel SP and MA Chamness. 2007. Geology Data Package for the Single-Shell Tank Waste Management Areas at the Hanford Site. PNNL-15955, Pacific Northwest National Laboratory, Richland, Washington.

Rhoades JD. 1996. "Salinity: Electrical Conductivity and Total Dissolved Solids.” In Methods of Soil Analysis Part 3, ed. JM Bigham, pp. 417-435. American Society of Agronomy, Madison, Wisconsin.

Serne RJ, HT Schaef, BN Bjornstad, BA Williams, DC Lanigan, DG Horton, RE Clayton, VL LeGore, MJ O’Hara, CF Brown, KE Parker, IV Kutnyakov, JN Serne, AV Mitroshkov, GV Last, SC Smith, CW Lindenmeier, JM Zachara, and DS Burke. 2002a. Characterization of Vadose Zone Sediment: Uncontaminated RCRA Borehole Core Samples and Composite Samples. PNNL-13757-1, Pacific Northwest National Laboratory, Richland, Washington.

Serne RJ, HT Schaef, BN Bjornstad, DC Lanigan, GW Gee, CW Lindenmeier, RE Clayton, VL LeGore, MJ O’Hara, CF Brown, RD Orr, G.V Last, IV Kutnyakov, DS Burke, TC Wilson, and BA Williams. 2002b. Characterization of Vadose Zone Sediment: Borehole 299-W23-19 [SX-115] in the S-SX Waste Management Area. PNNL-13757-2, Pacific Northwest National Laboratory, Richland, Washington.

Serne RJ, GV Last, HT Schaef, DC Lanigan, CW Lindenmeier, CC Ainsworth, RE Clayton, VL LeGore, MJ O'Hara, CF Brown, RD Orr, IV Kutnyakov, TC Wilson, KB Wagnon, BA Williams, and DB Burke. 2002c. Characterization of Vadose Zone Sediment, Part 4: Slant Borehole SX-108 in the S-SX Waste Management Area. PNNL-13757-4, Pacific Northwest National Laboratory, Richland, Washington.

Serne RJ, GV Last, GW Gee, HT Schaef, DC Lanigan, CW Lindenmeier, RE Clayton, VL LeGore, RD Orr, MJ O'Hara, CF Brown, DS Burke, AT Owen, IV Kutnyakov, and TC Wilson. 2002d. Characterization of Vadose Zone Sediment: Borehole 41-09-39 in the S-SX Waste Management Area. PNNL-13757-3, Pacific Northwest National Laboratory, Richland, Washington.

Serne RJ, GV Last, GW Gee, HT Schaef, DC Lanigan, CW Lindenmeier, MJ Lindberg, RE Clayton, VL LeGore, RD Orr, IV Kutnyakov, SR Baum, KN Geiszler, CF Brown, MM Valenta, and TS Vickerman. 
2002e. Characterization of Vadose Zone Sediment: Borehole 299-E33-45 Near BX-102 in the B-BX-BY Waste Management Area. PNNL-14083, Pacific Northwest National Laboratory, Richland, Washington.

Serne RJ, BN Bjornstad, GW Gee, HT Schaef, DC Lanigan, CW Lindenmeier, RD Orr, VL LeGore, RE Clayton, MJ Lindberg, IV Kutnyakov, SR Baum, KN Geiszler, MM Valenta, TS Vickerman, and LJ Royack. 2002f. Characterization of Vadose Zone Sediment: Borehole 299-E33-46 Near B-110 in the B-BX-BY Waste Management Area. PNNL-14119, Pacific Northwest National Laboratory, Richland, Washington.

Serne RJ, BN Bjornstad, DG Horton, DC Lanigan, CW Lindenmeier, MJ Lindberg, RE Clayton, VL LeGore, RD Orr, IV Kutnyakov, SR Baum, KN Geiszler, MM Valenta, and TS Vickerman. 2004a. Characterization of Vadose Zone Sediments Below the TX Tank Farm: Boreholes C3830, C3831, C3832 and RCRA Borehole 299-W10-27. PNNL-14594, Pacific Northwest National Laboratory, Richland, Washington.

Serne RJ, BN Bjornstad, DG Horton, DC Lanigan, HT Schaef, CW Lindenmeier, MJ Lindberg, RE Clayton, VL LeGore, KN Geiszler, SR Baum, MM Valenta, IV Kutnyakov, TS Vickerman, RD Orr, and CF Brown. 2004b. Characterization of Vadose Zone Sediments Below the T Tank Farm: Boreholes C4104, C4105, 299-W10-196, and RCRA Borehole 299-W11-39. PNNL-14849, Pacific Northwest National Laboratory, Richland, Washington.

Sobczyk SM. 2001. Subsurface interpretation of the T Tank Farm Hanford Site, Washington, based on gamma-ray logging. Nez Perce Tribe, Environmental Restoration, Lapwai, Idaho.

Slate JL. 2000. Nature and Variability of the Plio-Pleistocene Unit in the 200 West Area of the Hanford Site. BHI-01203, Bechtel Hanford, Inc., Richland, Washington.

Tallman AM, KR Fecht, MC Marratt, and GV Last. 1979. Geology of the Separations Areas, Hanford Site, South-Central Washington. RHO-ST-23, Rockwell Hanford Operations, Richland, Washington.

U.S. Department of Energy (DOE). 1992. T Plant Aggregate Area Management Study Report. DOE/RL91-61, U.S. Department of Energy, Richland Operations Office, Richland Washington.

U.S. Department of Energy (DOE). 1997. Hanford Tank Farms Vadose Zone, TX Tank Farm Report. GJO-HAN-11, prepared by U.S. Department of Energy Grand Junction Office for U.S. Department of Energy, Richland Operations Office, Richland, Washington.

U.S. Department of Energy (DOE). 1998. Consultation Draft Site Characterization Plan, Reference Repository Location, Hanford Site, Washington. RW-0164, U.S. Department of Energy, Office of Civilian Radioactive Waste Management, Washington, D.C.

U.S. Department of Energy (DOE). 1999. Phase 1 RCRA Facility Investigation/Corrective Measures Study Work Plan for the SST Waste Management Areas. DOE/RL-99-36, Rev. 0, U.S. Department of Energy, Richland Operations Office, Richland, Washington.

U.S. Department of Energy (DOE). 2002. Standardized Stratigraphic Nomenclature for Post-RingoldFormation Sediments Within the Pasco Basin. DOE/RL-2002-39, U.S. Department of Energy, Richland Operations Office, Richland, Washington. 
U.S. Geological Survey (USGS). 2001. "Alkalinity and Acid Neutralizing Capacity.” National Field Manual for the Collection of Water-Quality Data, $2^{\text {nd }}$ ed., eds. SA Rounds and FD Wilde. March 23, 2004 Available URL: http://water.usgs.gov/owq/FieldManual/Chapter6/section6.6/html/section6.6.htm

Wentworth CK. 1922. "A Grade Scale and Class Terms for Clastic Sediments." Journal of Geology 30:377-392.

Wood MI, R Schalla, BN Bjornstad, and FN Hodges. 2001. Subsurface Conditions Description of the T and TX-TY Waste Management Areas. RPP-7123, Rev. 0, CH2M HILL Hanford Group, Inc., Richland, Washington. 



\section{Appendix A}

Photographs of Core and Grab Samples from the Direct Push Boreholes in the Vicinity of Single-Shell Tanks 241-TY-105 and 241-TY-106 



\section{Appendix A}

\section{Photographs of Core and Grab Samples from the Direct Push Boreholes in the Vicinity of Single-Shell Tanks 241-TY-105 and 241-TY-106}

A.1 Sample S06001-1A from Direct-Push Vertical Borehole C4604 ….................................... A.2

A.2 Sample S06001-1 from Direct-Push Vertical Borehole C4604 …........................................ A.3

A.3 Sample S06001-4C from Direct-Push Vertical Borehole C4606 ............................................ A.4

A.4 Sample S06001-4B from Direct-Push Vertical Borehole C4606 ............................................ A.5

A.5 Sample S06001-4A from Direct-Push Vertical Borehole C4606 ........................................ A.6

A.6 Sample S06001-4 from Direct-Push Vertical Borehole C4606 .......................................... A.7

A.7 Sample S06001-3A from Direct-Push Vertical Borehole C4610 ….................................... A.8

A.8 Sample S06001-3 from Direct-Push Vertical Borehole C4610 …......................................... A.9

A.9 Sample S06001-5 from Direct-Push Vertical Borehole C4622 …....................................... A.10

A.10 Sample S06001-2B from Direct-Push Vertical Borehole C4624 ........................................ A.11

A.11 Sample S06001-2A from Direct-Push Vertical Borehole C4624 ........................................ A.12

A.12 Sample S06001-2 from Direct-Push Vertical Borehole C4624 ............................................. A.13 


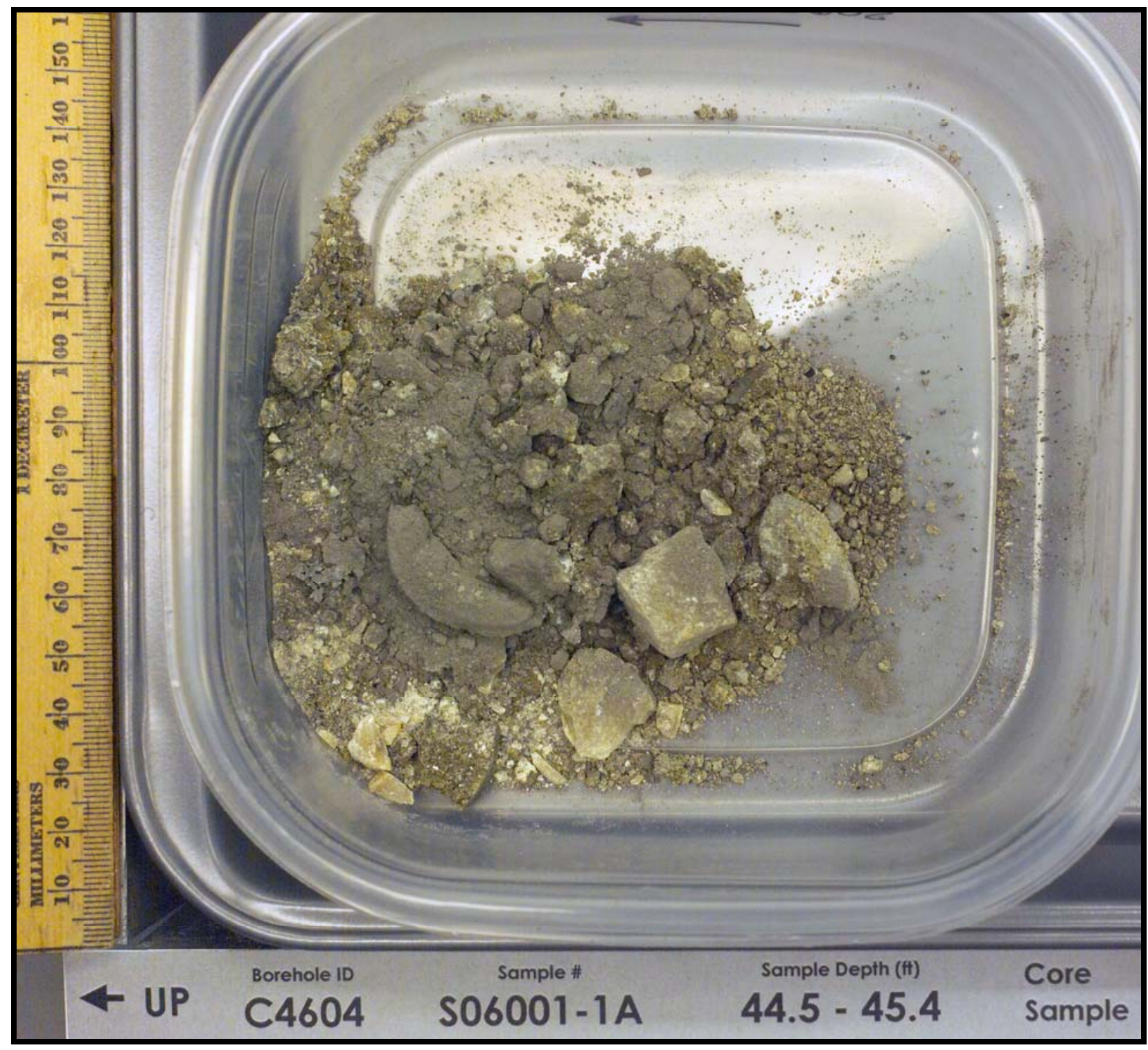

Figure A.1. Sample S06001-1A from Direct-Push Vertical Borehole C4604 


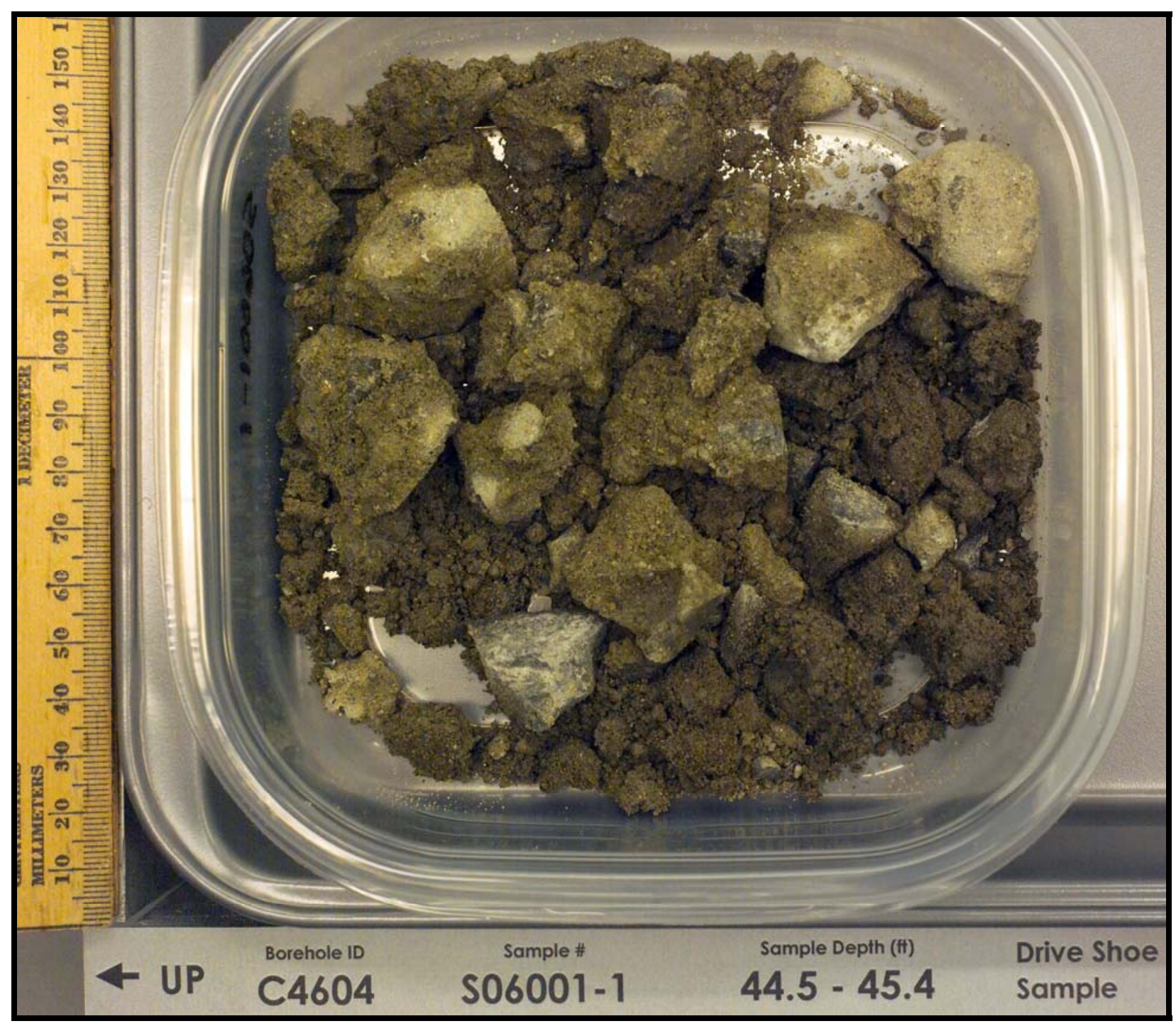

Figure A.2. Sample S06001-1 from Direct-Push Vertical Borehole C4604 


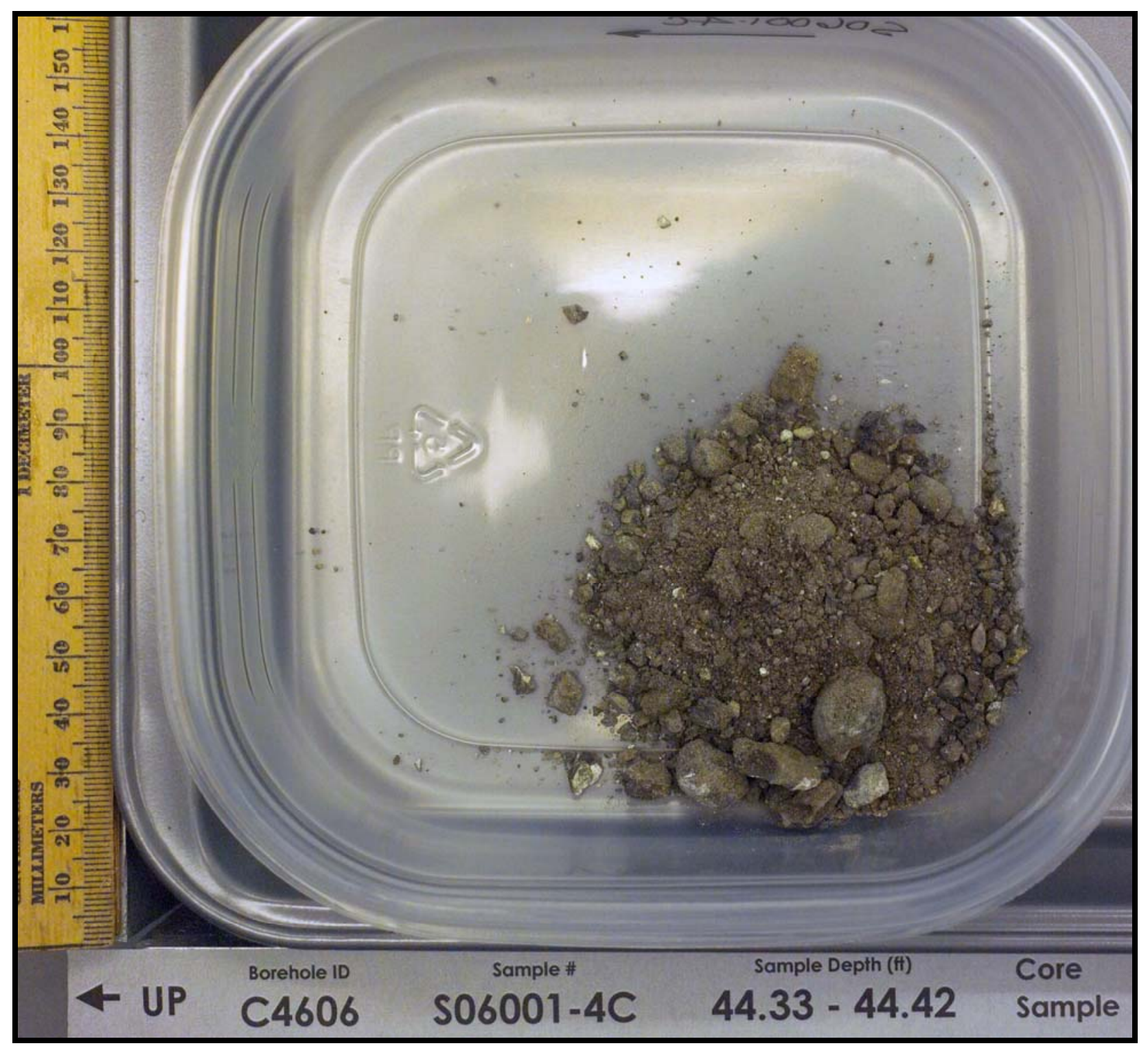

Figure A.3. Sample S06001-4C from Direct-Push Vertical Borehole C4606 


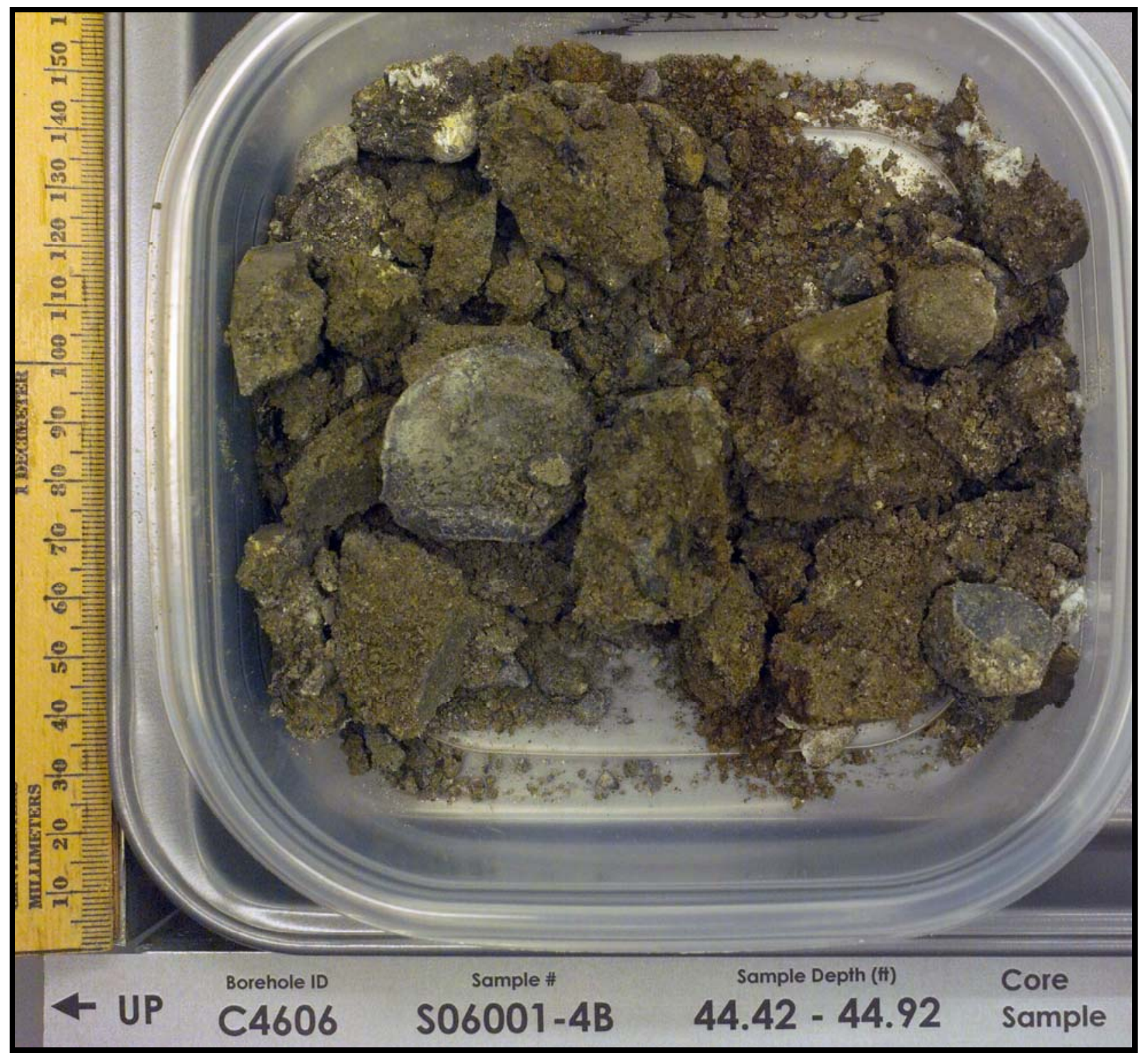

Figure A.4. Sample S06001-4B from Direct-Push Vertical Borehole C4606 


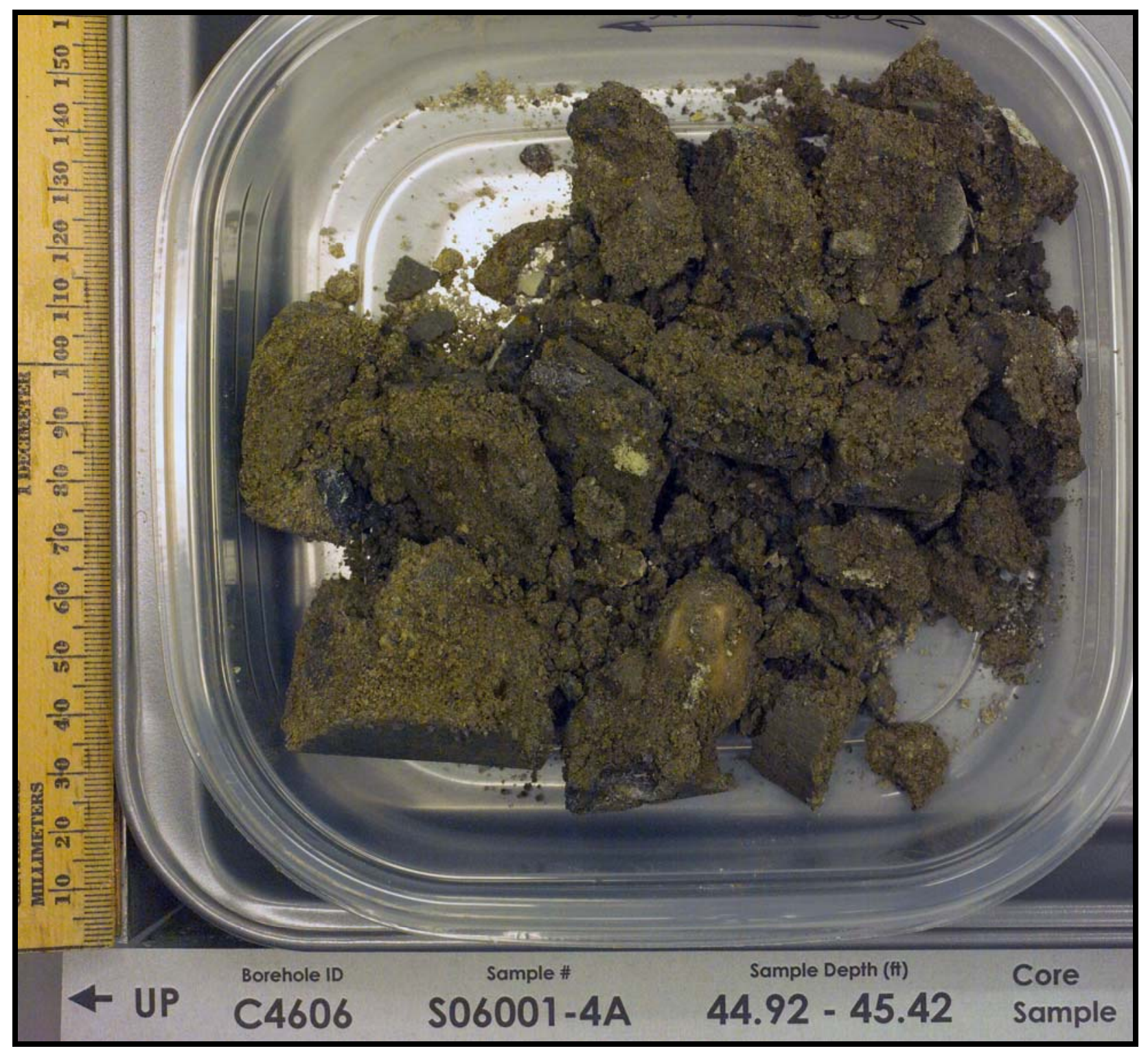

Figure A.5. Sample S06001-4A from Direct-Push Vertical Borehole C4606 


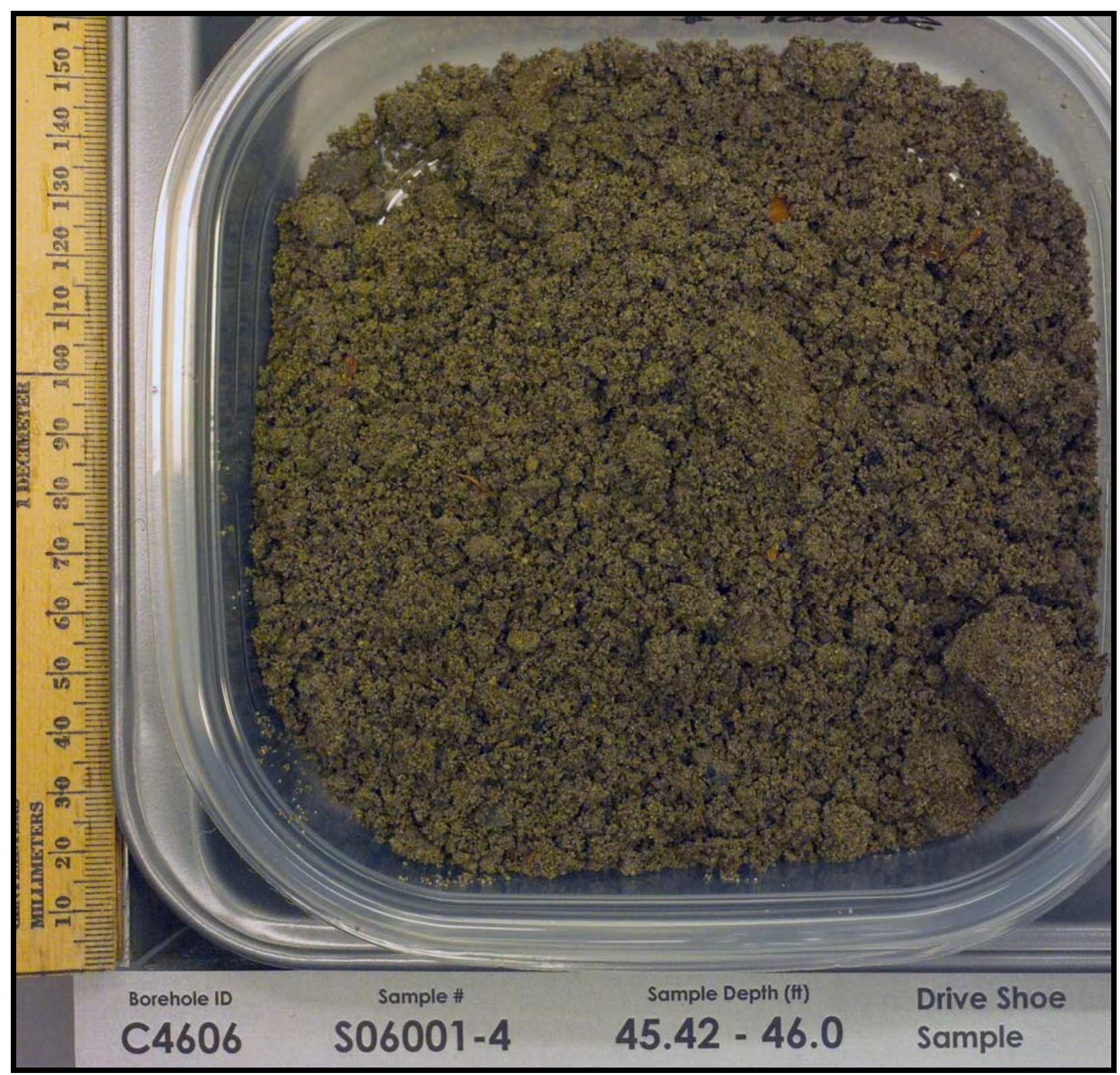

Figure A.6. Sample S06001-4 from Direct-Push Vertical Borehole C4606 


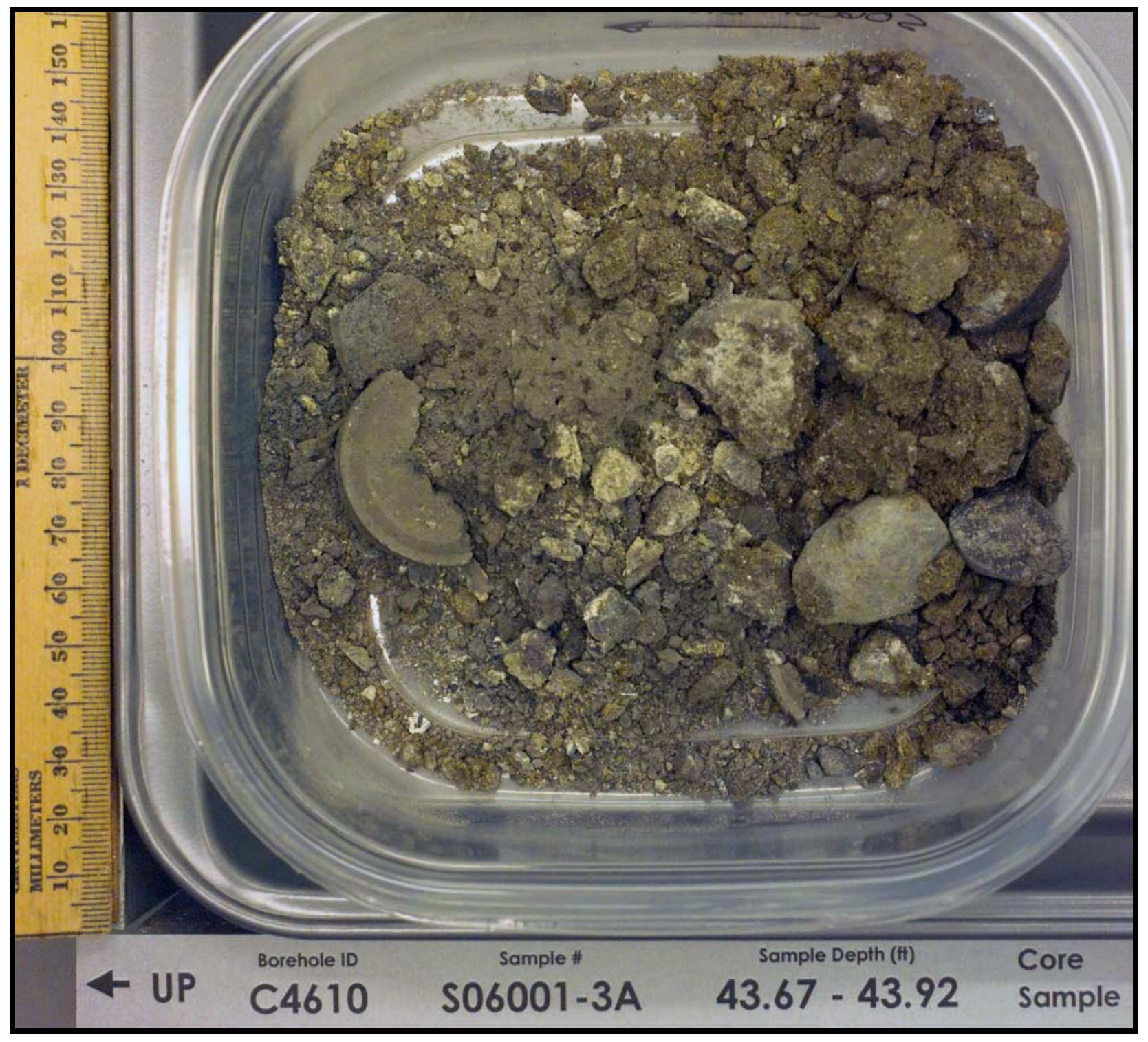

Figure A.7. Sample S06001-3A from Direct-Push Vertical Borehole C4610 


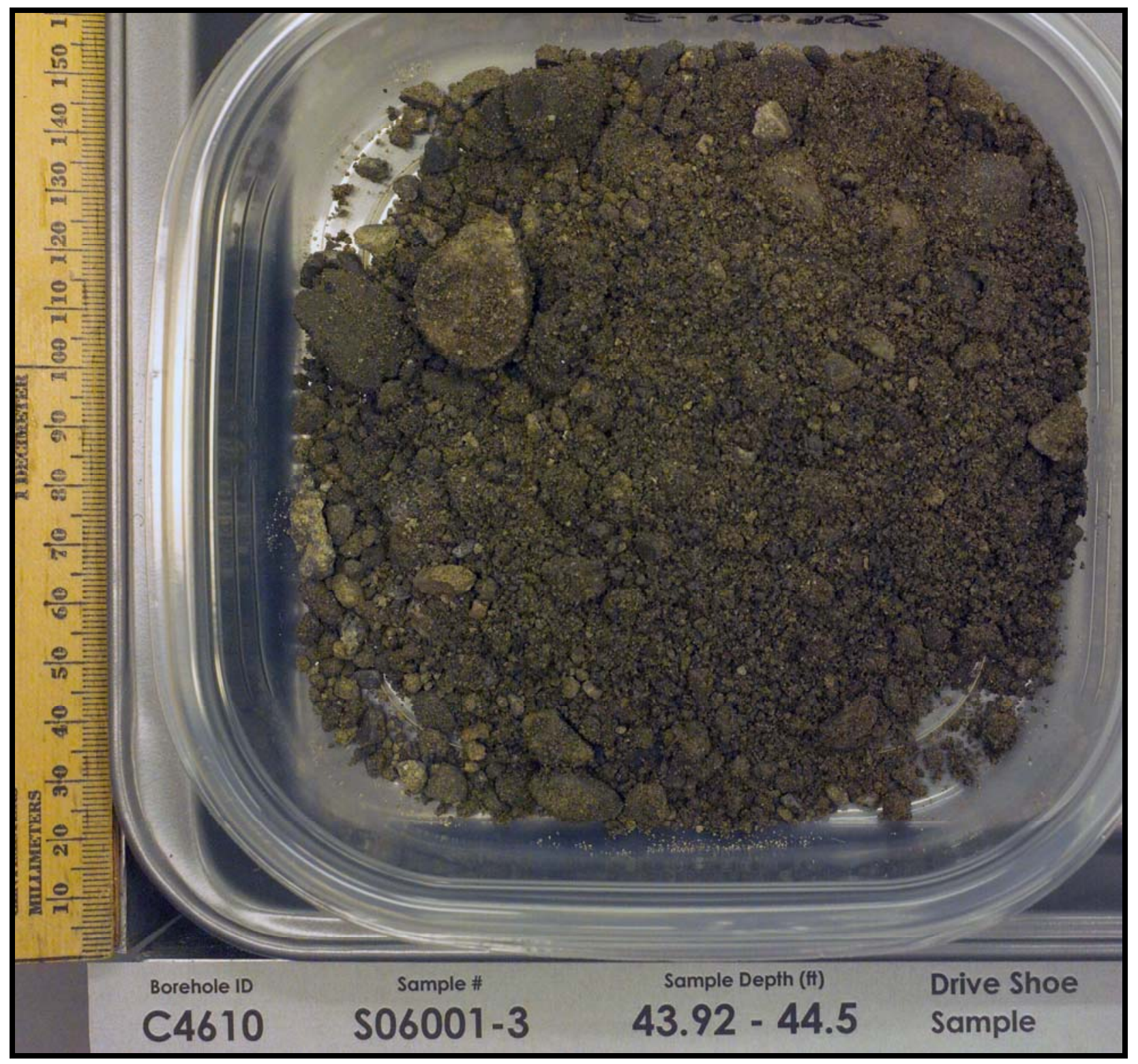

Figure A.8. Sample S06001-3 from Direct-Push Vertical Borehole C4610 


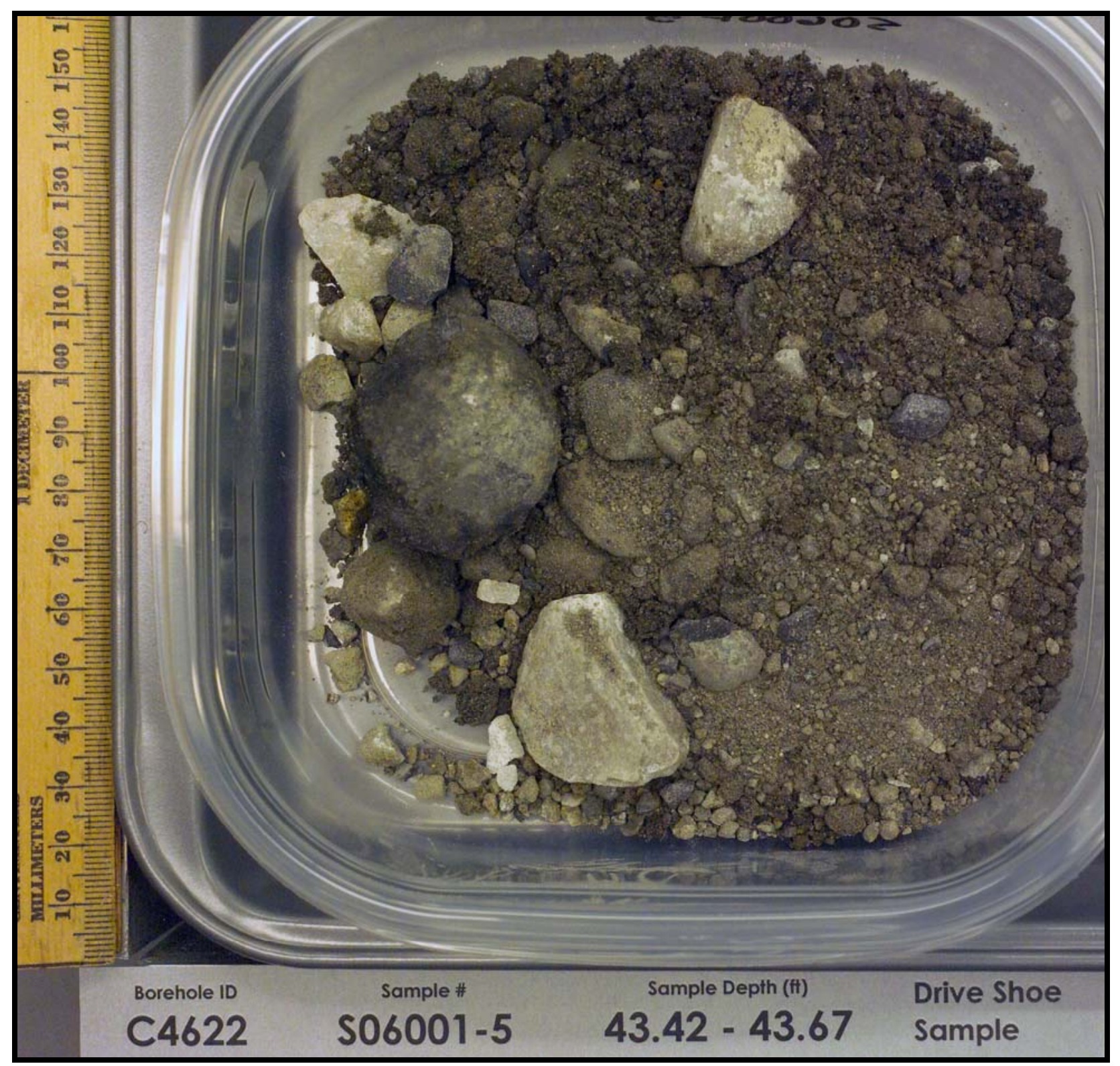

Figure A.9. Sample S06001-5 from Direct-Push Vertical Borehole C4622 


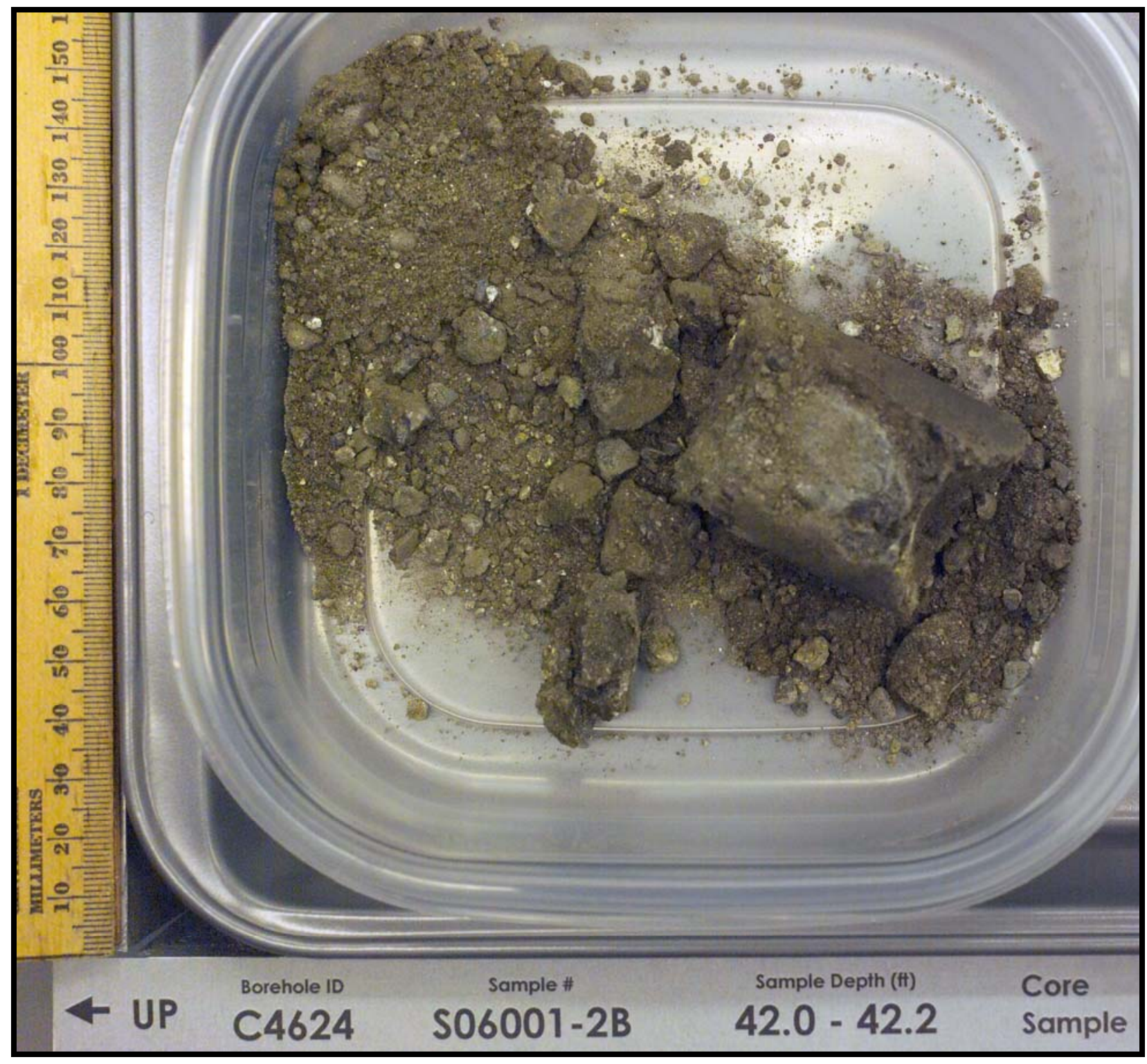

Figure A.10. Sample S06001-2B from Direct-Push Vertical Borehole C4624 


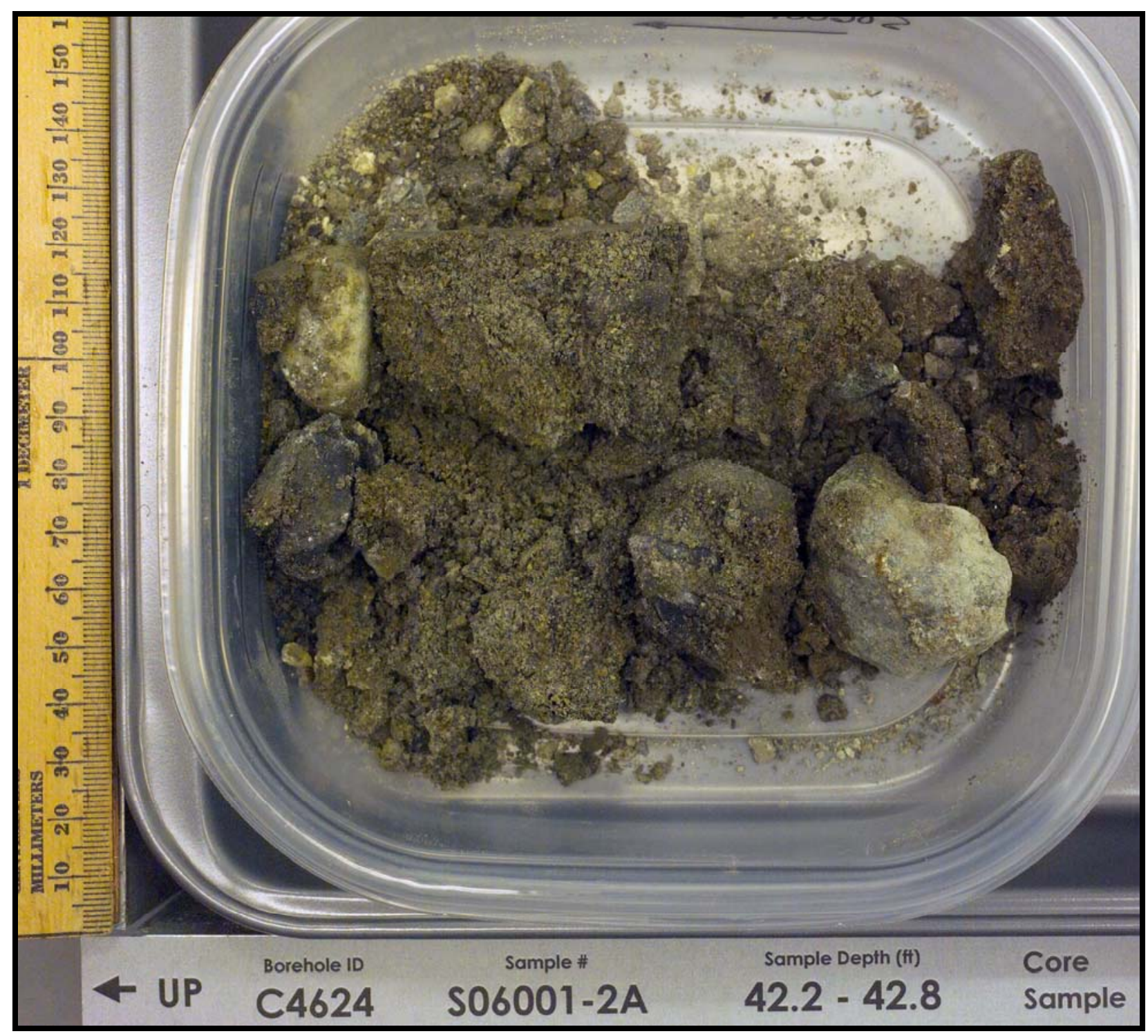

Figure A.11. Sample S06001-2A from Direct-Push Vertical Borehole C4624 


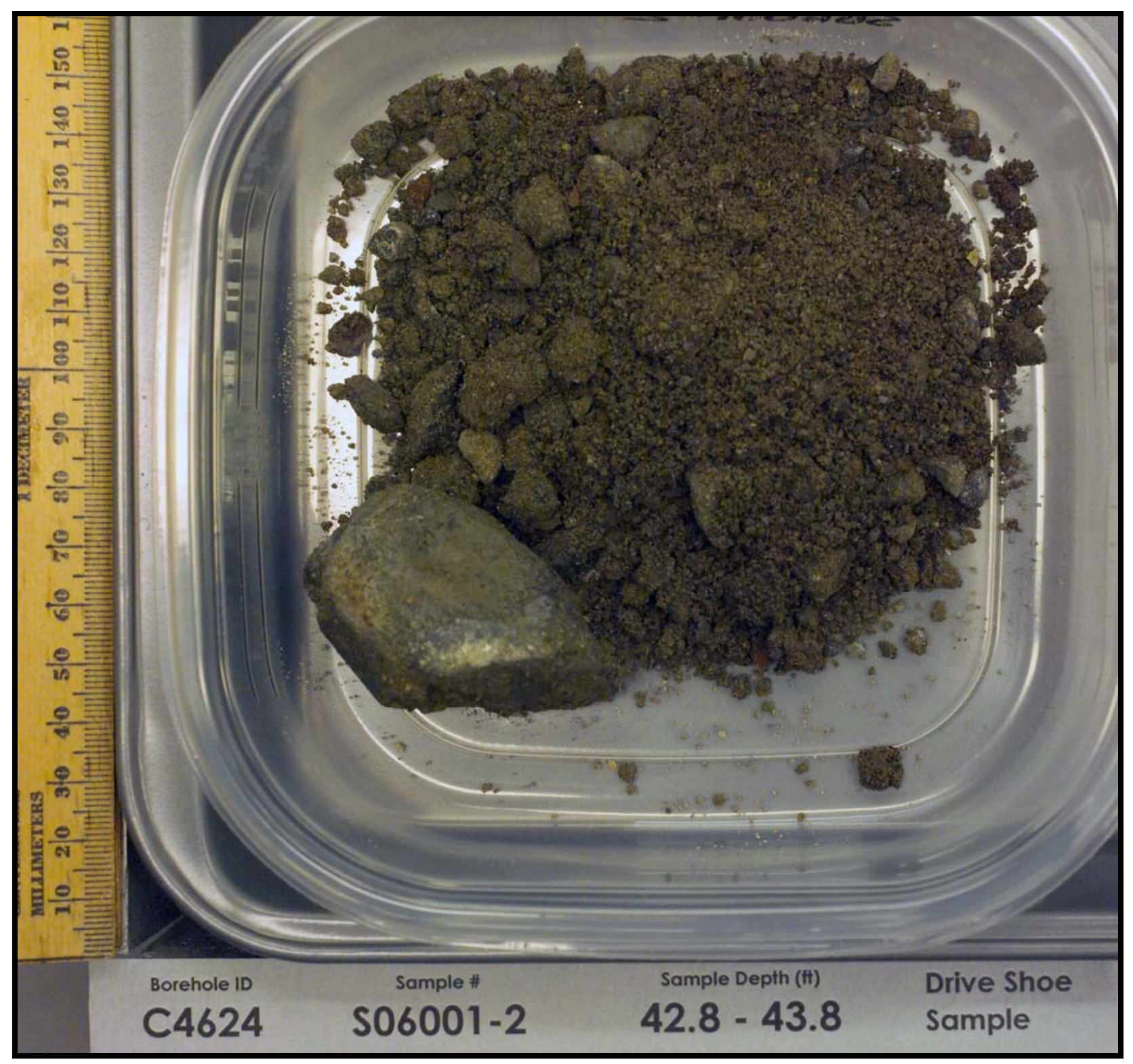

Figure A.12. Sample S06001-2 from Direct-Push Vertical Borehole C4624 



\section{Appendix B}

Logs of Core and Grab Samples from the Direct Push Boreholes in the Vicinity of Single-Shell Tanks 241-TY-105 and 241-TY-106 



\section{Appendix B}

\section{Logs of Core and Grab Samples from the Direct Push Boreholes in the Vicinity of Single-Shell Tanks 241-TY-105 and 241-TY-106}

B.1 Core Log for Direct-Push Vertical Borehole C4604 …................................................ B.2

B.2 Core Log for Direct-Push Vertical Borehole C4606 ........................................................ B.3

B.3 Core Log for Direct-Push Vertical Borehole C4610 ........................................................ B.4

B.4 Core Log for Direct-Push Vertical Borehole C4622 …..................................................... B...

B.5 Core Log for Direct-Push Vertical Borehole C4624 ........................................................ B.. B. 


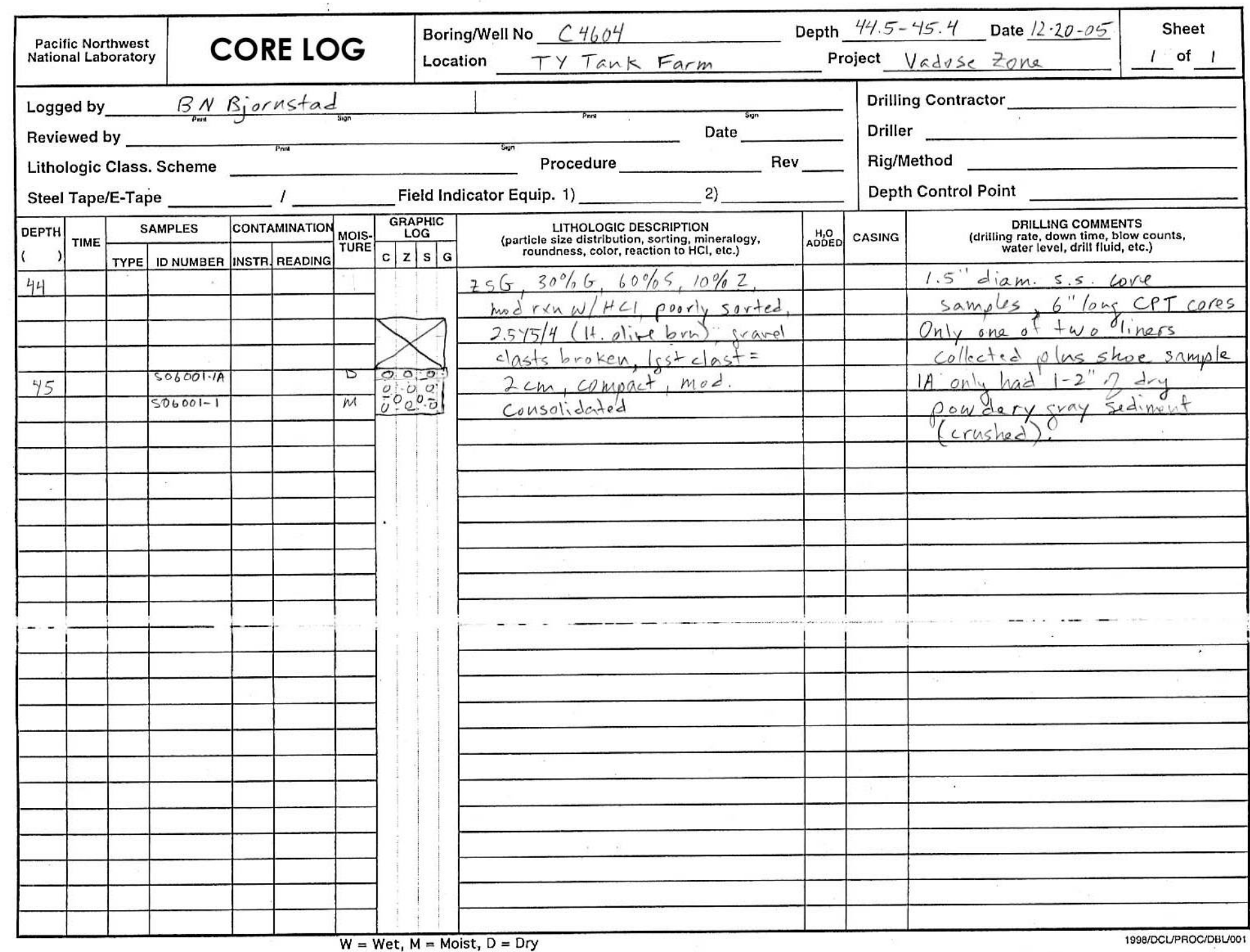

Figure B.1. Core Log for Direct-Push Vertical Borehole C4604 


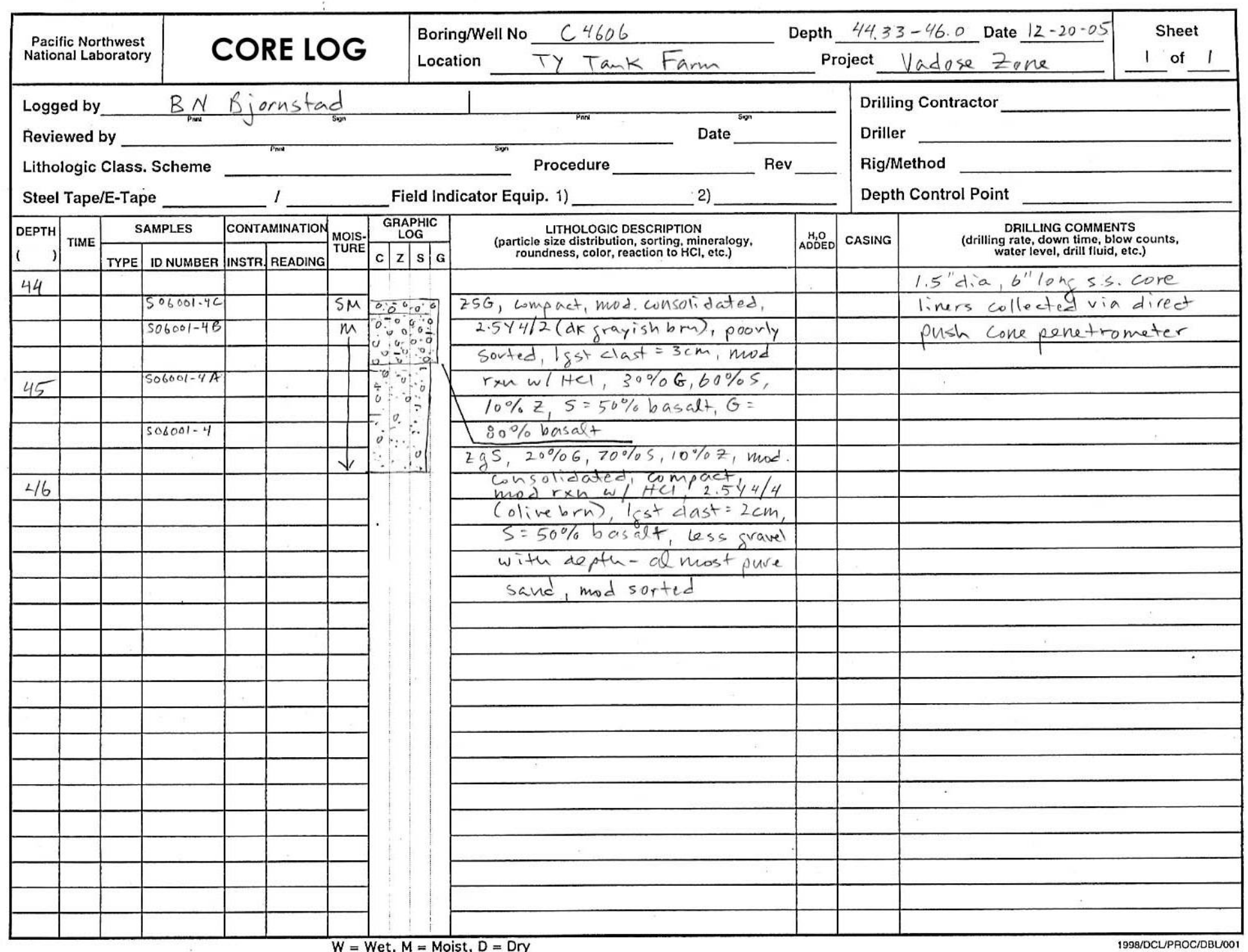

Figure B.2. Core Log for Direct-Push Vertical Borehole C4606 


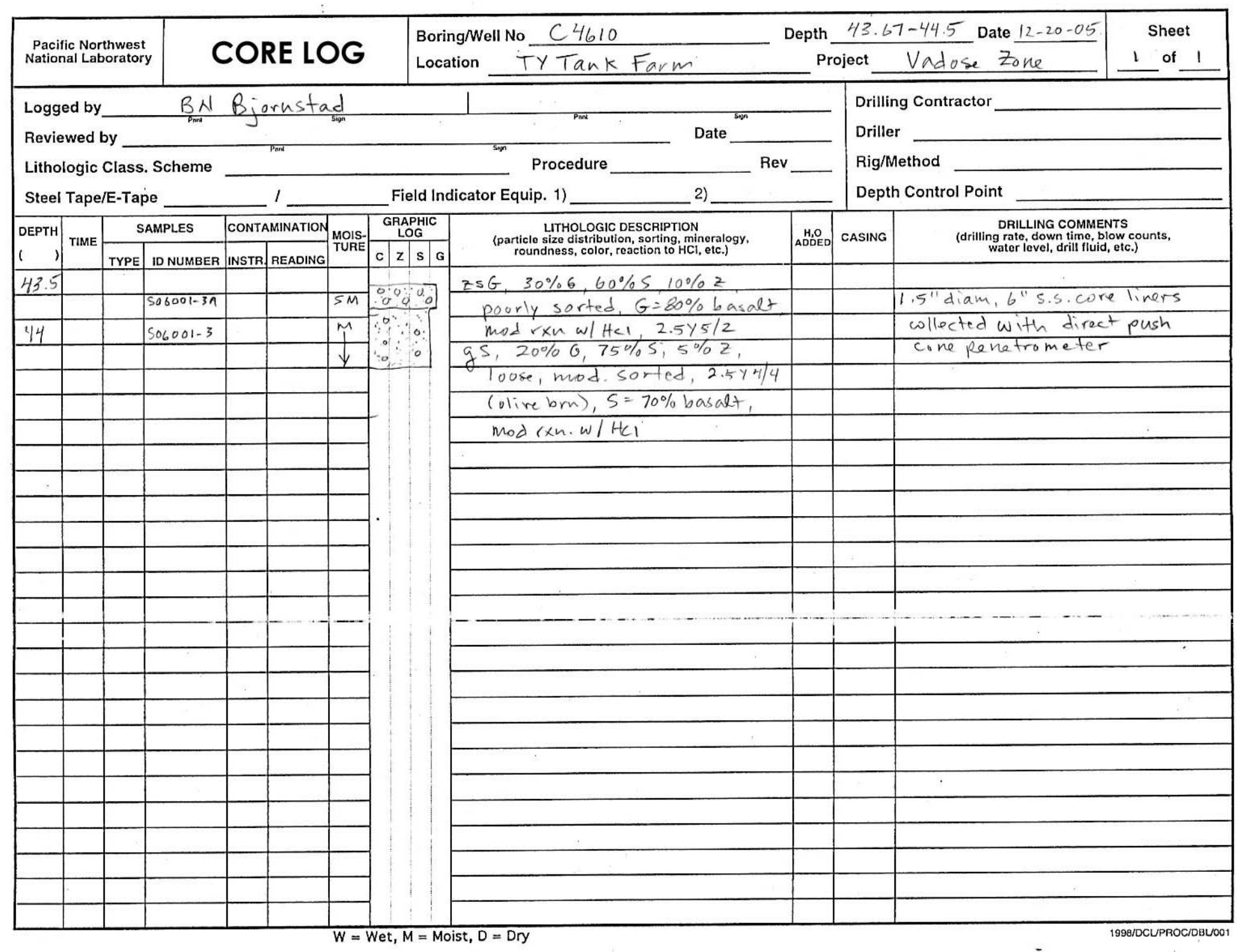

Figure B.3. Core Log for Direct-Push Vertical Borehole C4610 


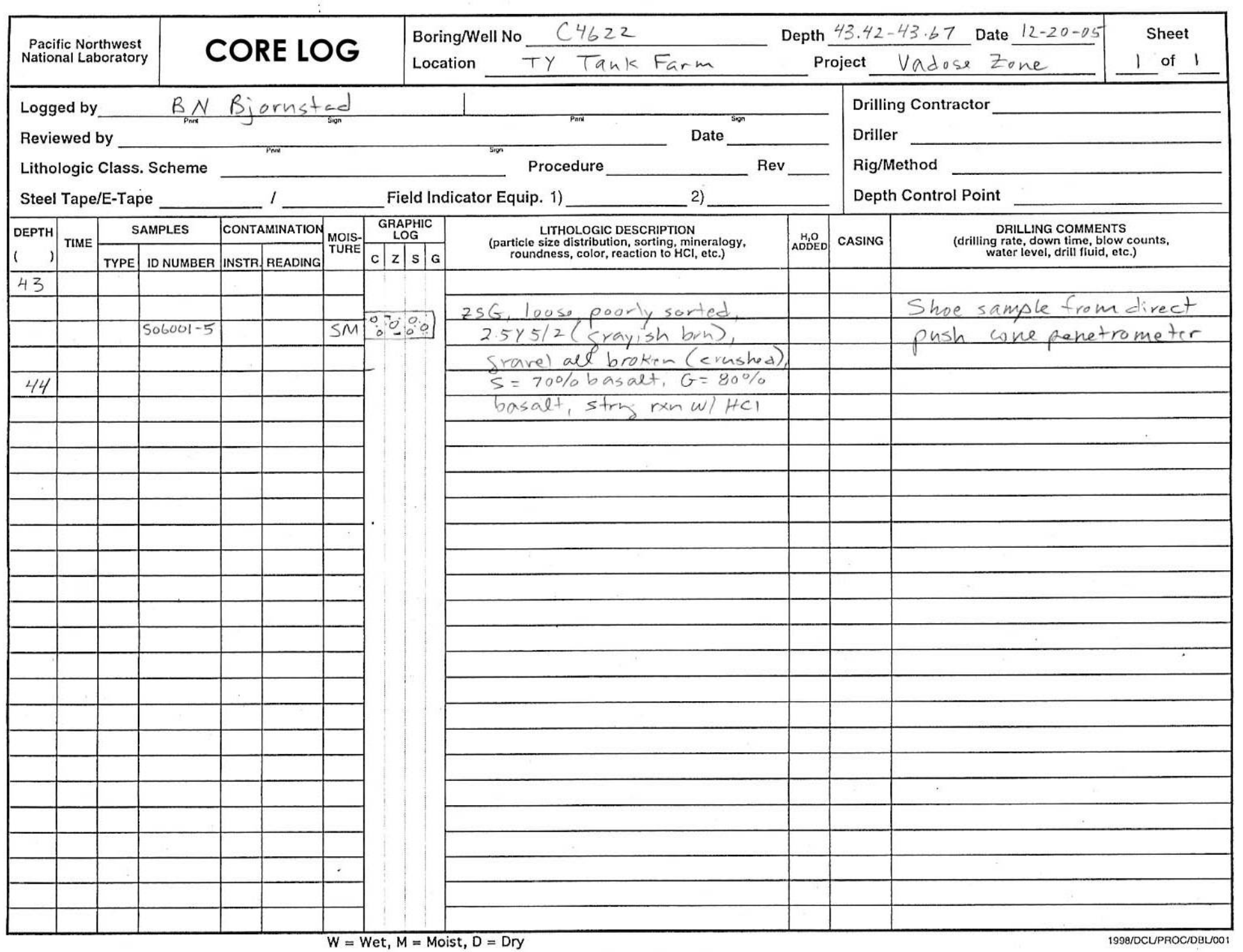

Figure B.4. Core Log for Direct-Push Vertical Borehole C4622 


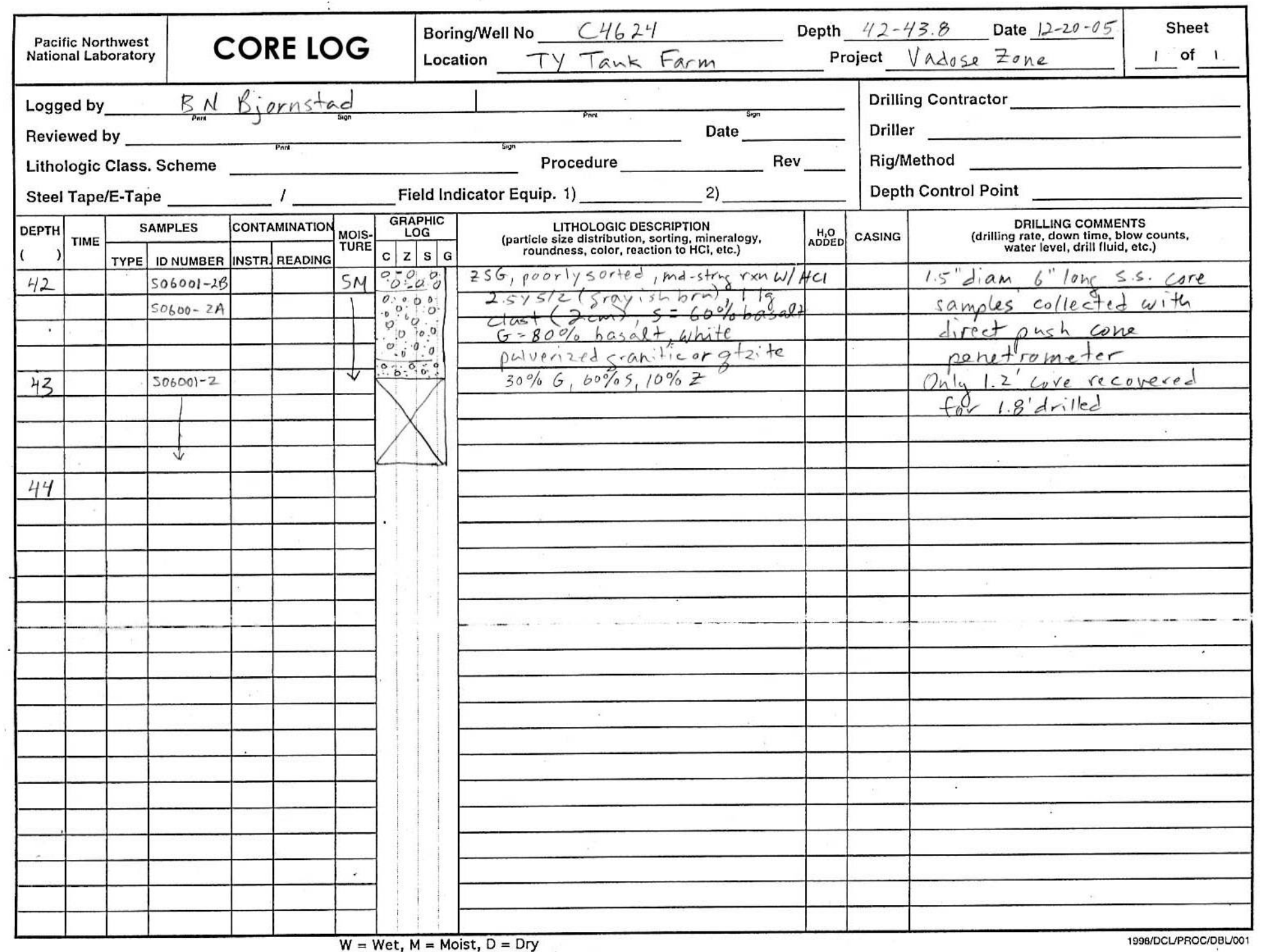

Figure B.5. Core Log for Direct-Push Vertical Borehole C4624 


\section{Appendix C}

Photographs of Core and Grab Samples from the Direct Push Boreholes in the Vicinity of Single Shell Tanks 241-T-101 and 241-T-104 



\section{Appendix C}

\section{Photographs of Core and Grab Samples from the Direct Push Boreholes in the Vicinity of Single Shell Tanks 241-T-101 and 241-T-104}

C.1 Sample B1KC36C from Direct-Push Vertical Borehole C4596 .......................................... C.2

C.2 Sample B1KC36B from Direct-Push Vertical Borehole C4596 …........................................ C.3

C.3 Sample B1KC36A from Direct-Push Vertical Borehole C4596 …......................................... C.4

C.4 Sample B1KC36 from Direct-Push Vertical Borehole C4596............................................ C.5

C.5 Sample B1KC35B from Direct-Push Vertical Borehole C4598 …...................................... C.6

C.6 Sample B1KC35A from Direct-Push Vertical Borehole C4598 _.......................................... C.7

C.7 Sample B1KC40C from Direct-Push Vertical Borehole C5374 …...................................... C.8

C.8 Sample B1KC40B from Direct-Push Vertical Borehole C5374 …....................................... C.9

C.9 Sample B1KC40A from Direct-Push Vertical Borehole C5374 …...................................... C.. C.10

C.10 Sample B1KC40 from Direct-Push Vertical Borehole C5374 ............................................ C.11

C.11 Sample B1KC37C from Direct-Push Vertical Borehole C5378 …...................................... C.12

C.12 Sample B1KC37B from Direct-Push Vertical Borehole C5378 .......................................... C.13

C.13 Sample B1KC37A from Direct-Push Vertical Borehole C5378 _.......................................... C.. C.14

C.14 Sample B1KC38B from Direct-Push Vertical Borehole C5378 …...................................... C.15

C.15 Sample B1KC38B from Direct-Push Vertical Borehole C5378 …...................................... C.. C.16

C.16 Sample B1KC38A from Direct-Push Vertical Borehole C5378 …........................................ C.17

C.17 Sample B1KC38 from Direct-Push Vertical Borehole C5378 .............................................. C.. 18

C.18 Sample B1LB08C from Direct-Push Vertical Borehole C5380 ........................................ C.19

C.19 Sample B1LB08B from Direct-Push Vertical Borehole C5380 …..................................... C.20

C.20 Sample B1LB08A from Direct-Push Vertical Borehole C5380 …..................................... C.21

C.21 Sample B1LB08 from Direct-Push Vertical Borehole C5380 …......................................... C.22

C.22 Sample B1LB07C from Direct-Push Vertical Borehole C5382 …...................................... C. 23

C.23 Sample B1LB07B from Direct-Push Vertical Borehole C5382 …..................................... C.24

C.24 Sample B1LB07A from Direct-Push Vertical Borehole C5382 …...................................... C.25

C.25 Sample B1KC39C from Direct-Push Vertical Borehole C5384 …......................................... C.26

C.26 Sample B1KC39B from Direct-Push Vertical Borehole C5384 …....................................... C... C.

C.27 Sample B1KC39A from Direct-Push Vertical Borehole C5384 …...................................... C.28

C.28 Sample B1KC39 from Direct-Push Vertical Borehole C5384 .............................................. C.29 


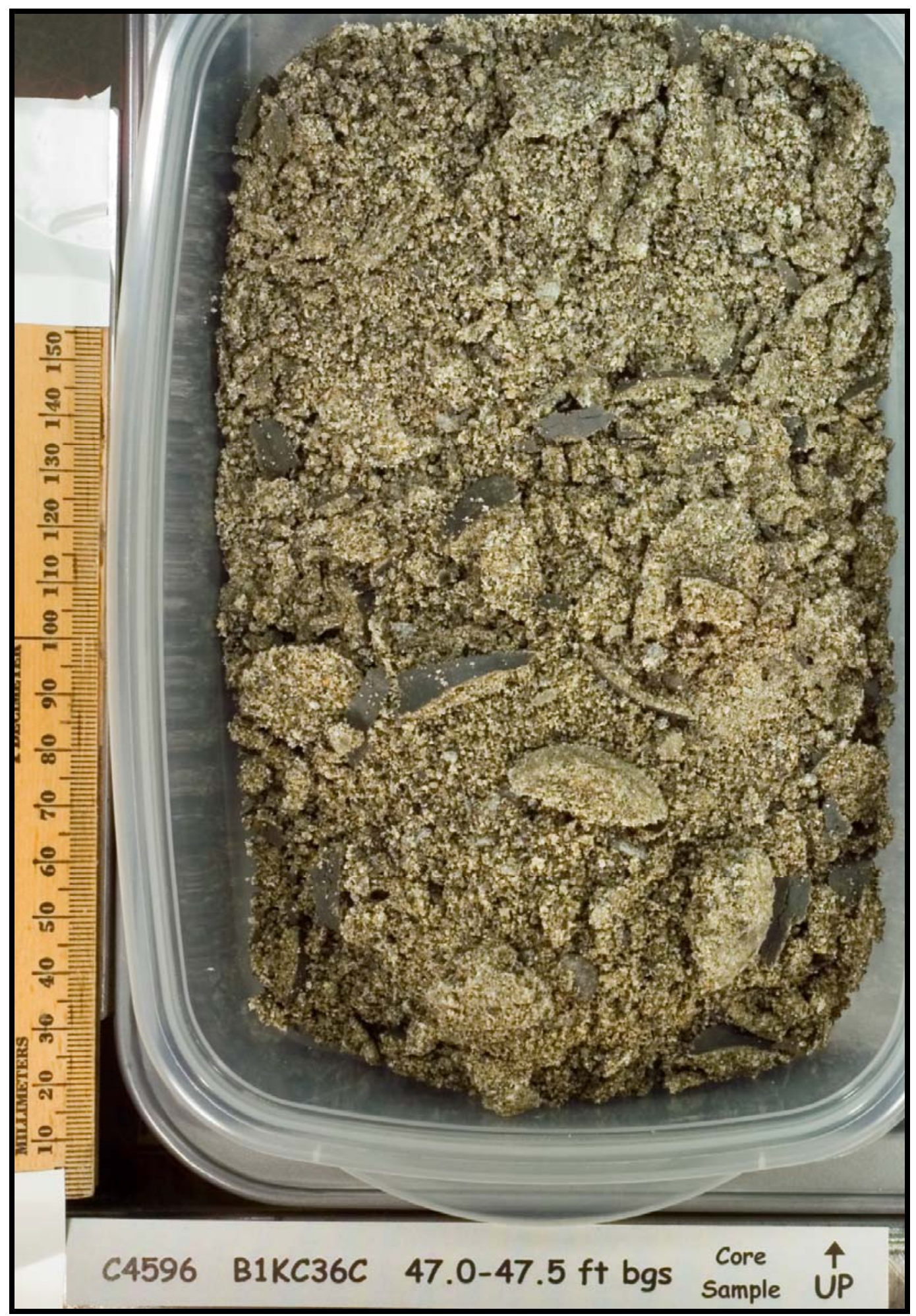

Figure C.1. Sample B1KC36C from Direct-Push Vertical Borehole C4596 


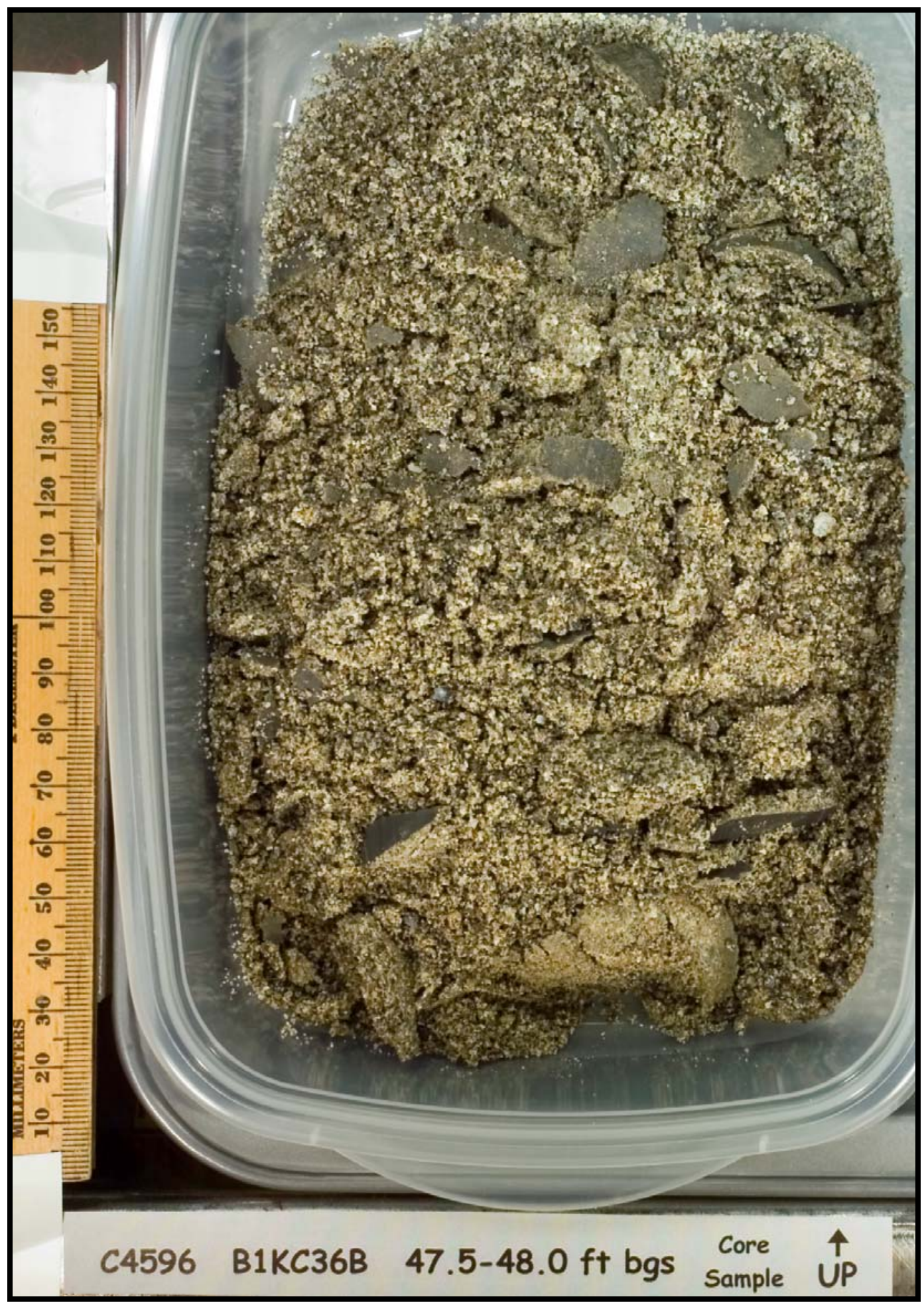

Figure C.2. Sample B1KC36B from Direct-Push Vertical Borehole C4596 


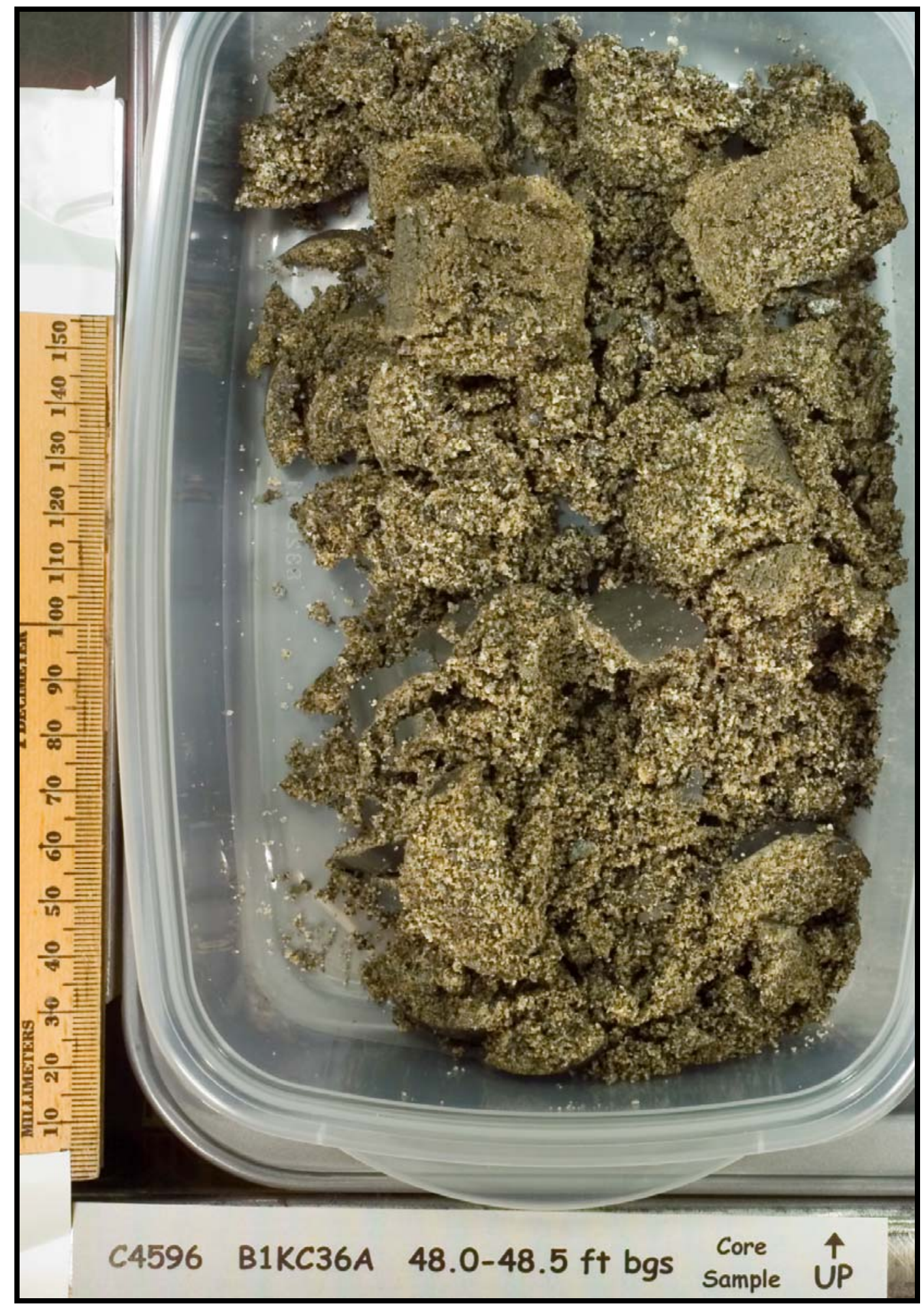

Figure C.3. Sample B1KC36A from Direct-Push Vertical Borehole C4596 


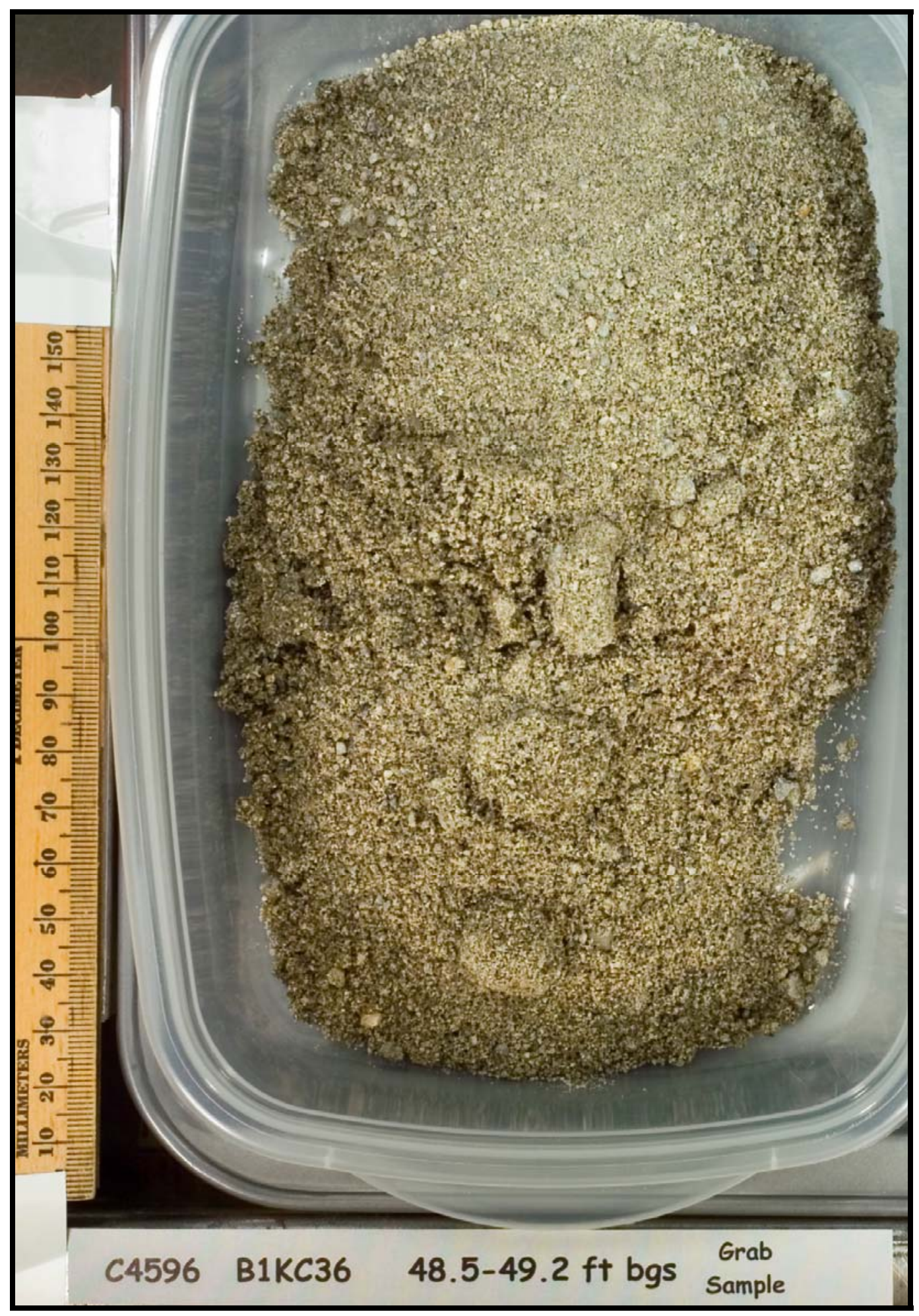

Figure C.4. Sample B1KC36 from Direct-Push Vertical Borehole C4596 


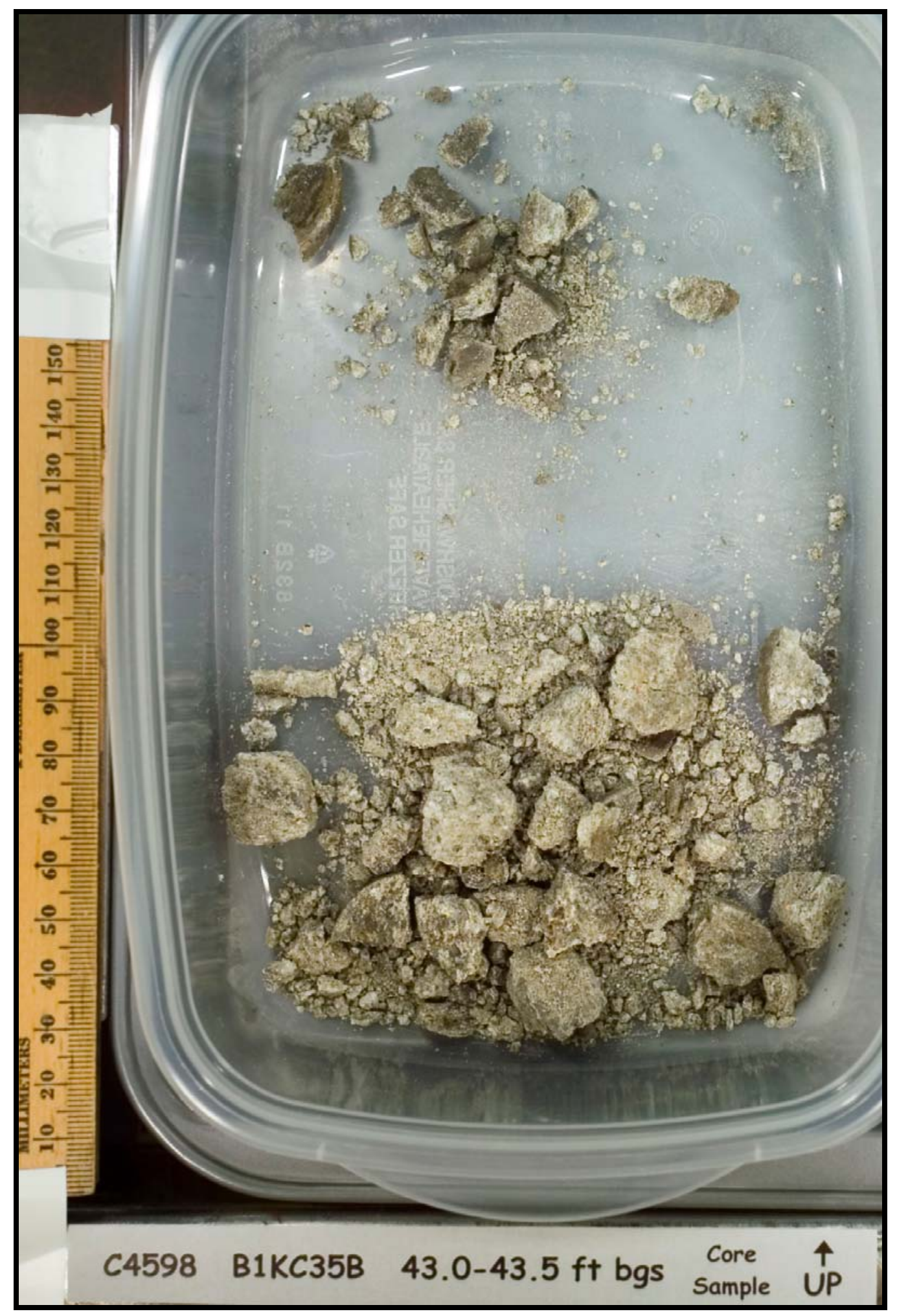

Figure C.5. Sample B1KC35B from Direct-Push Vertical Borehole C4598 


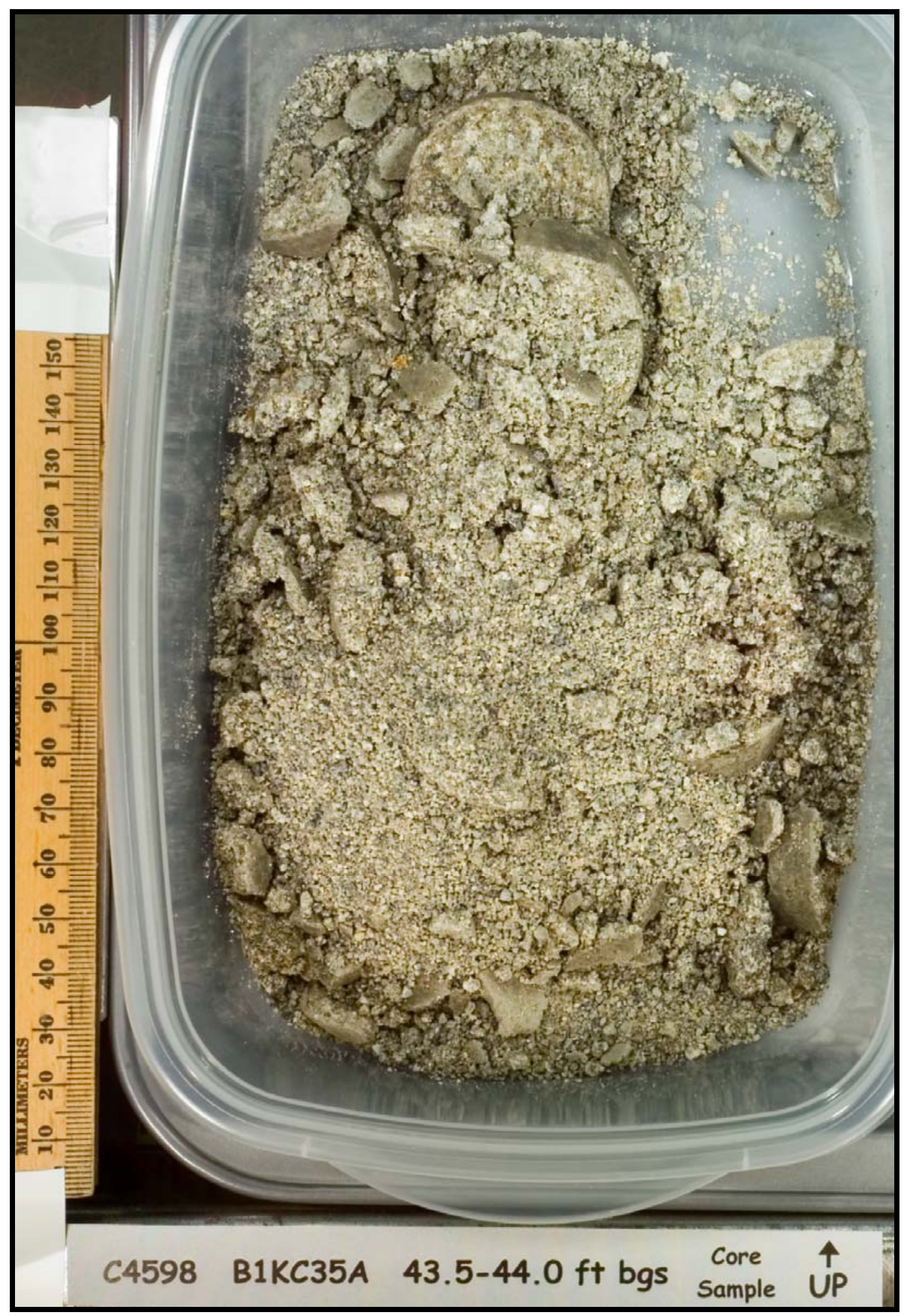

Figure C.6. Sample B1KC35A from Direct-Push Vertical Borehole C4598 


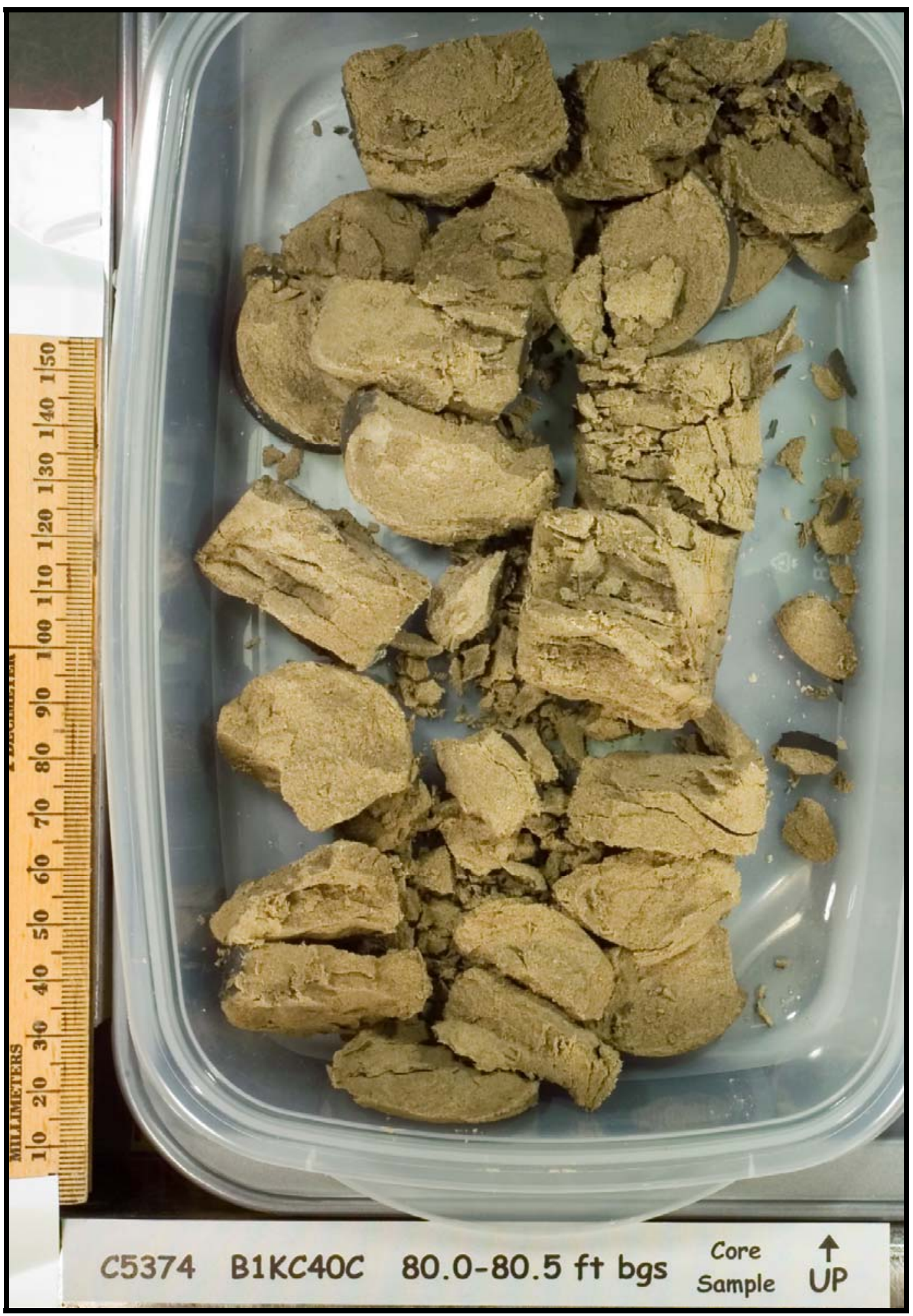

Figure C.7. Sample B1KC40C from Direct-Push Vertical Borehole C5374 


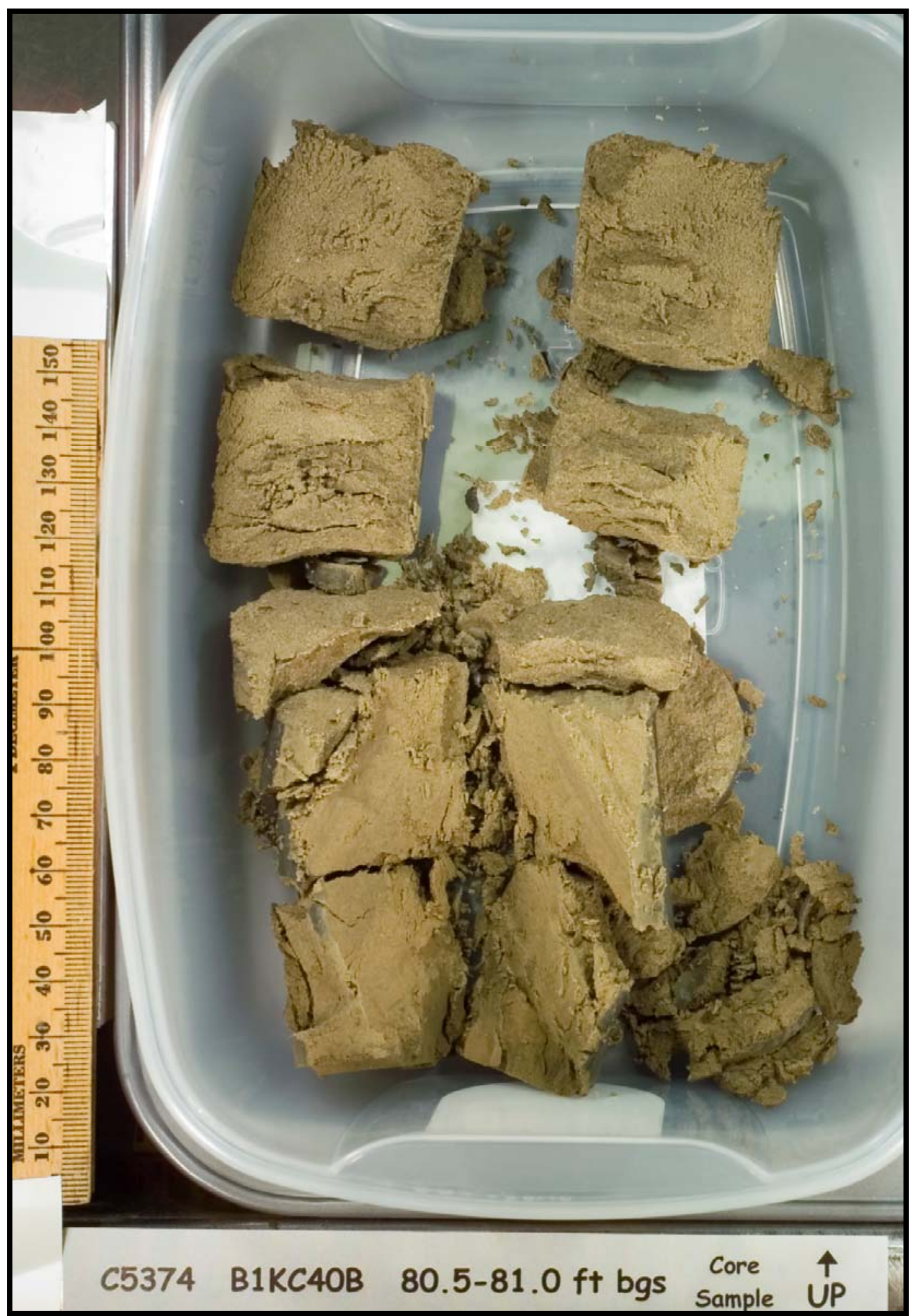

Figure C.8. Sample B1KC40B from Direct-Push Vertical Borehole C5374 


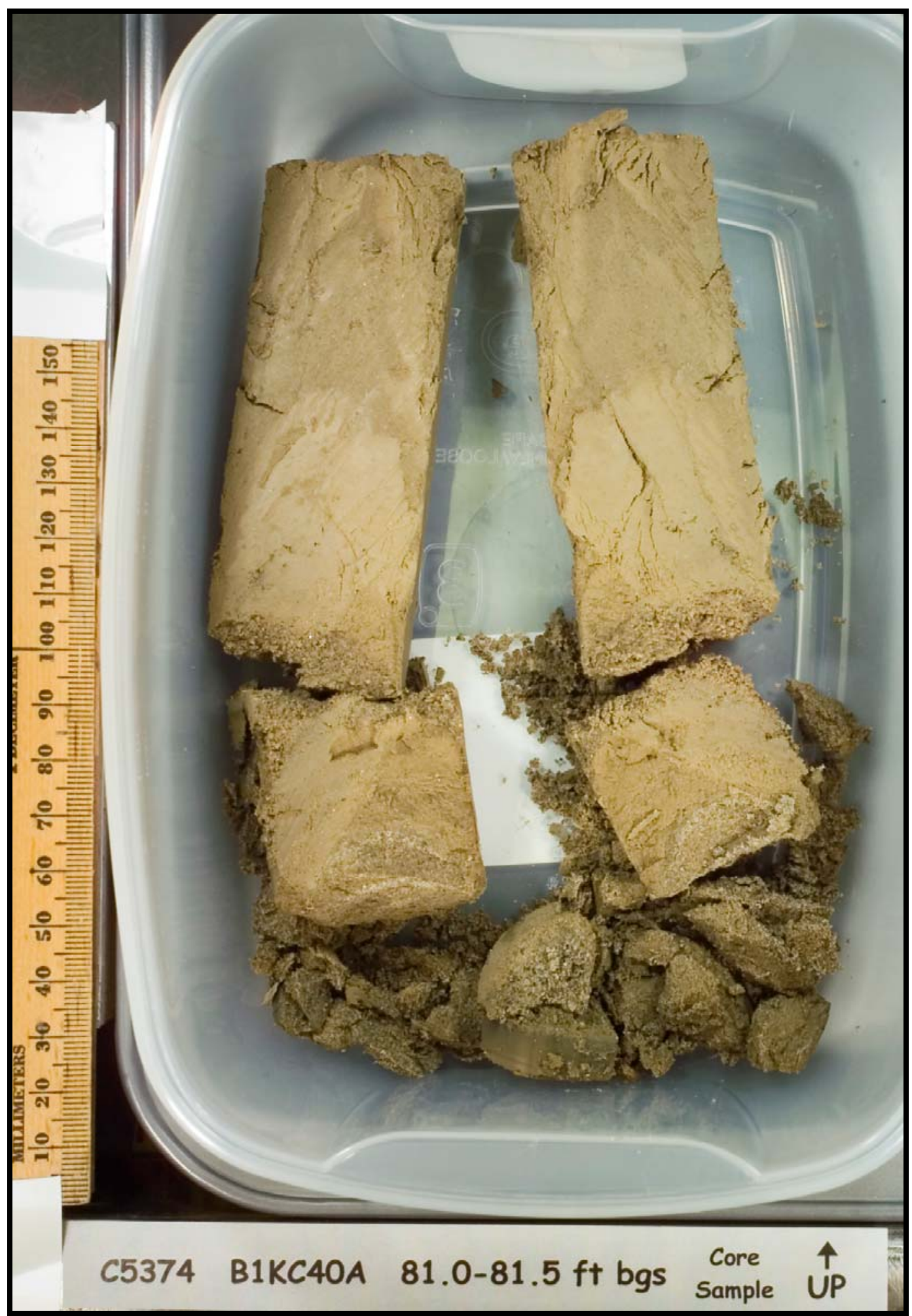

Figure C.9. Sample B1KC40A from Direct-Push Vertical Borehole C5374 


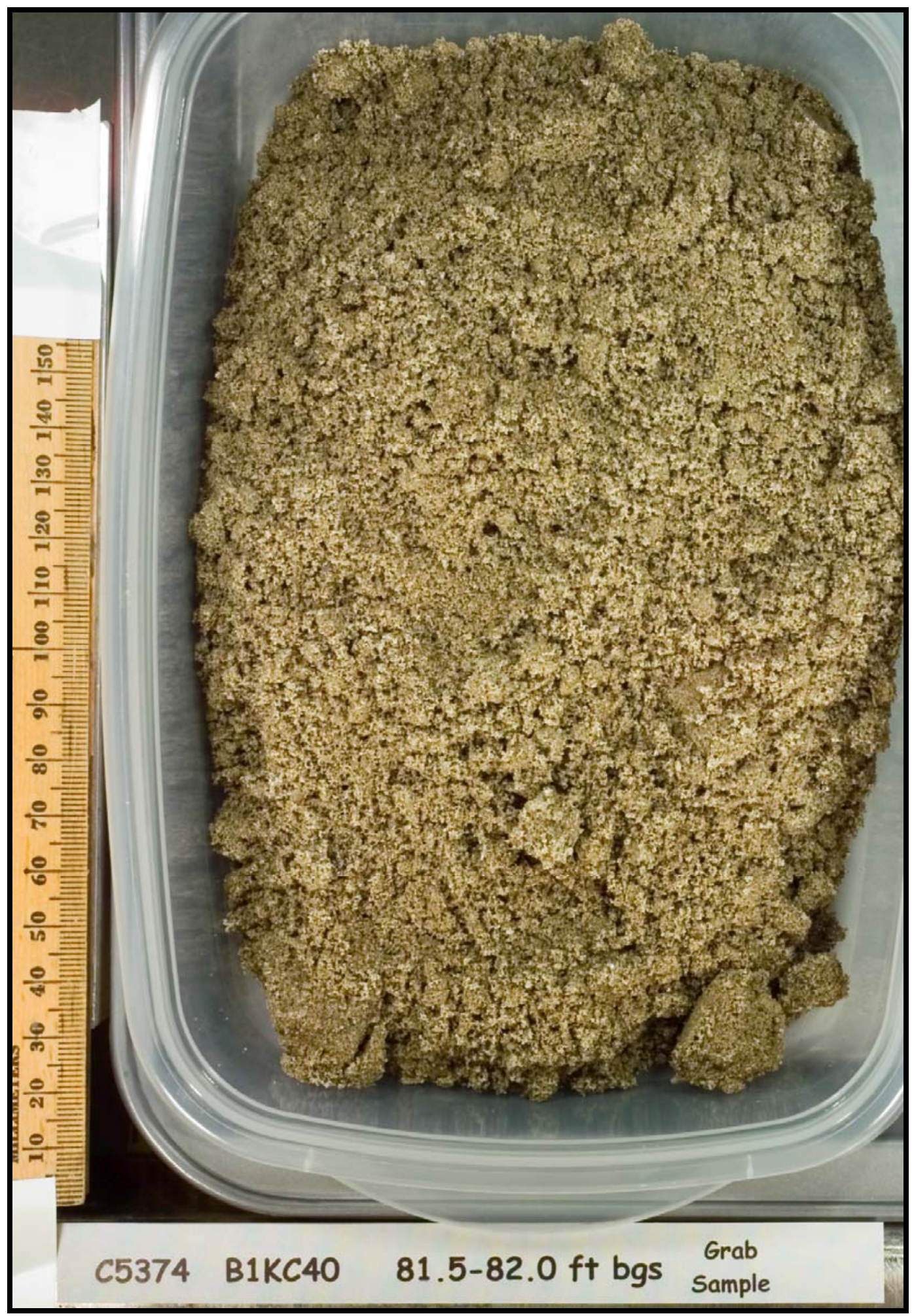

Figure C.10. Sample B1KC40 from Direct-Push Vertical Borehole C5374 


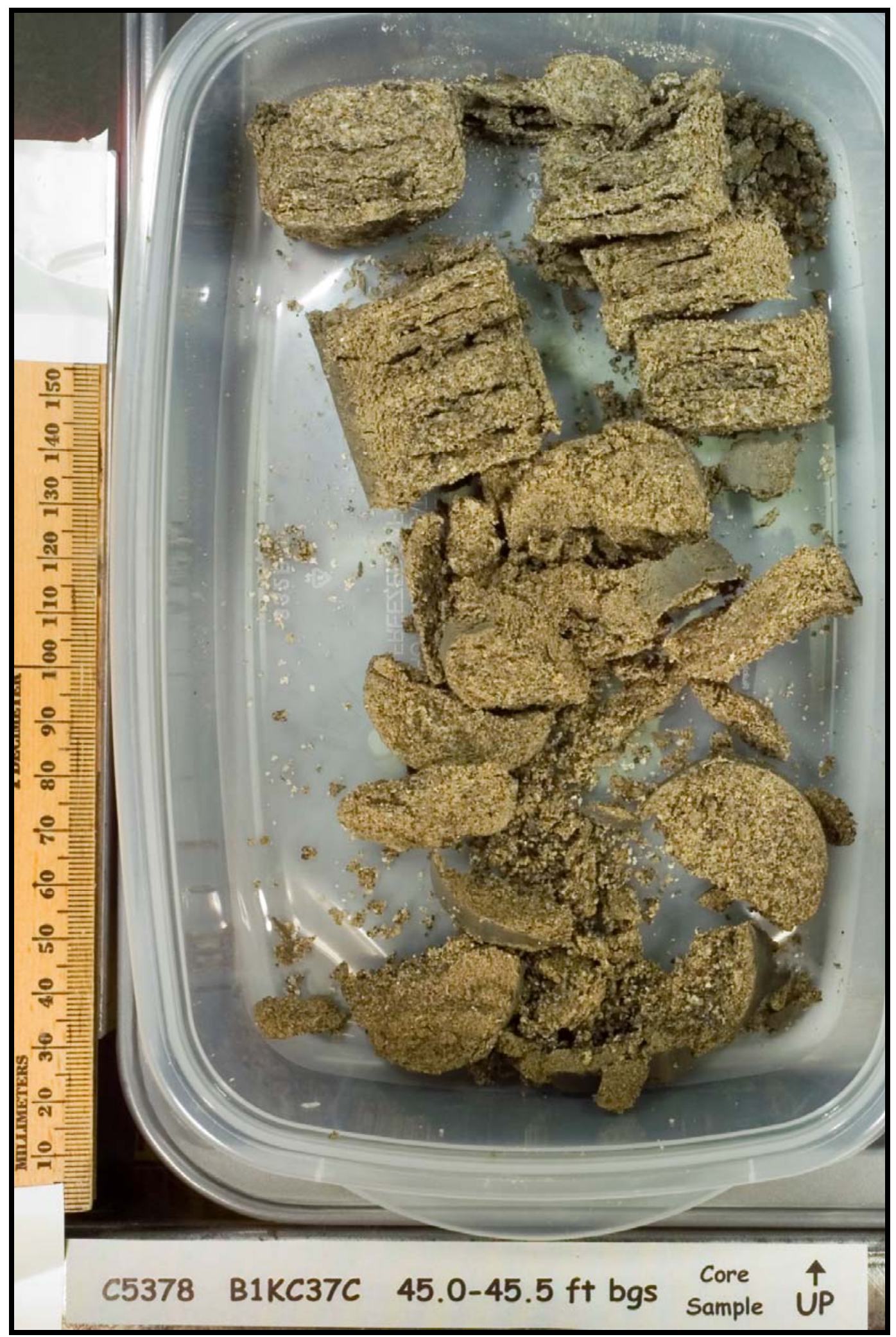

Figure C.11. Sample B1KC37C from Direct-Push Vertical Borehole C5378 


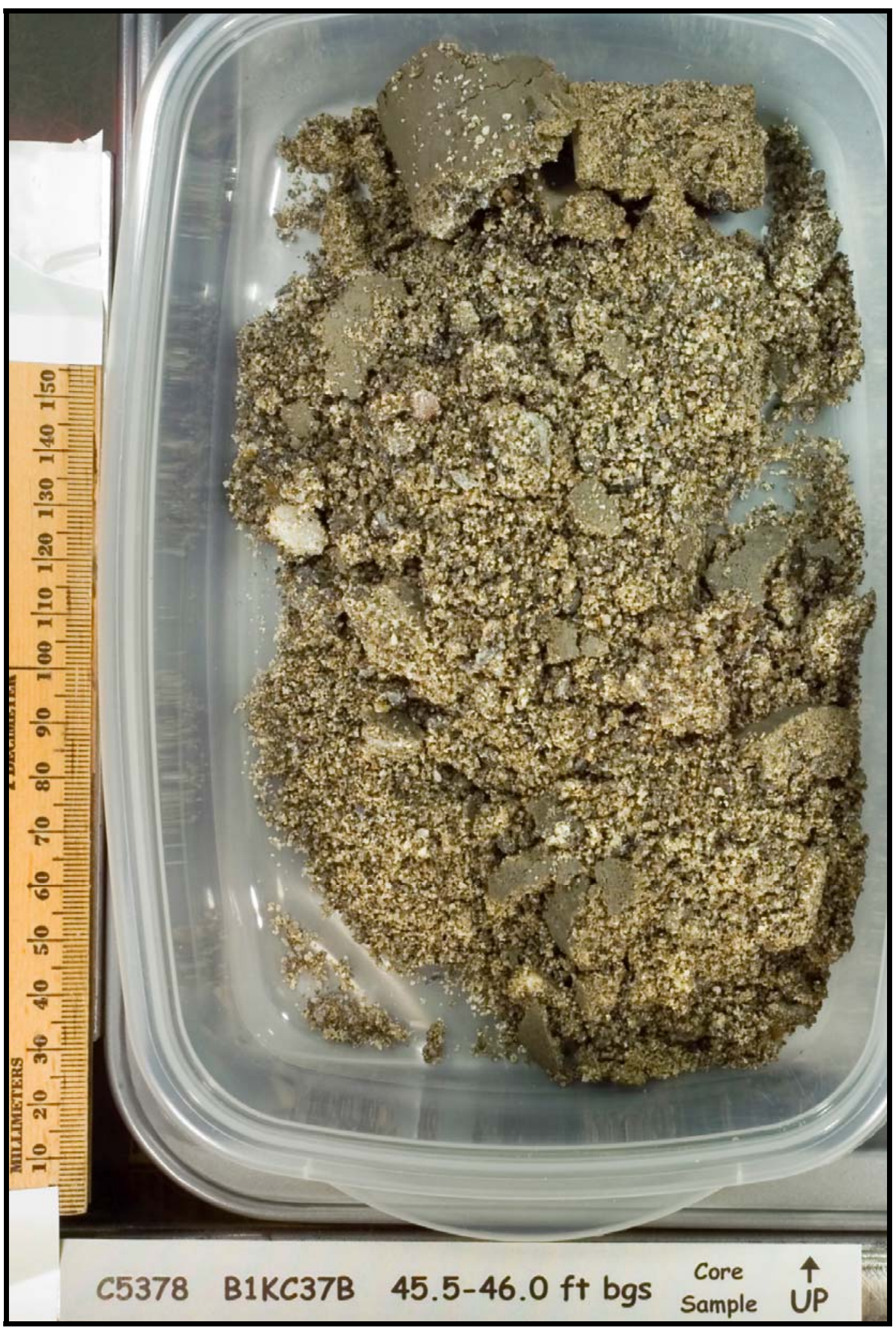

Figure C.12. Sample B1KC37B from Direct-Push Vertical Borehole C5378 


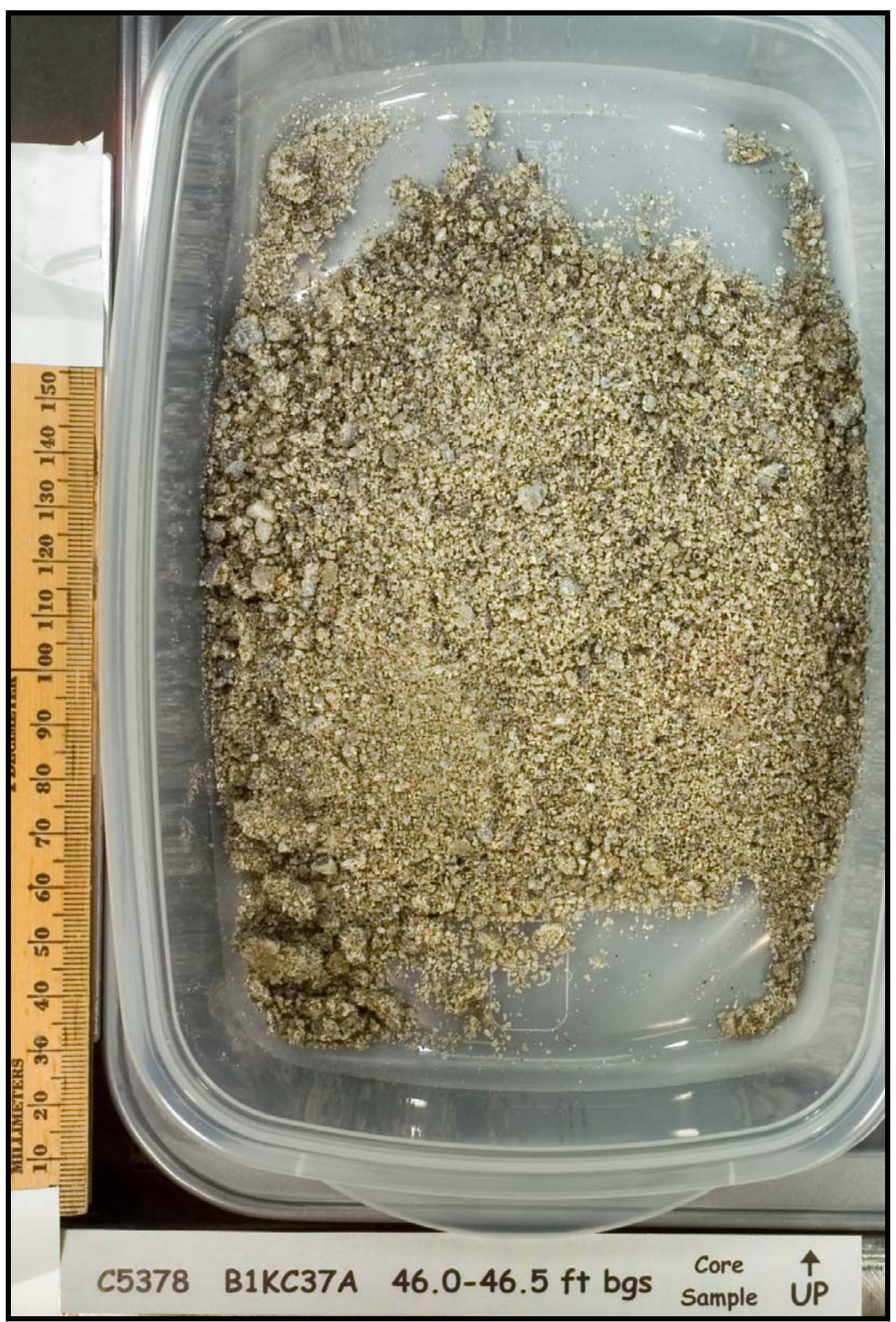

Figure C.13. Sample B1KC37A from Direct-Push Vertical Borehole C5378 


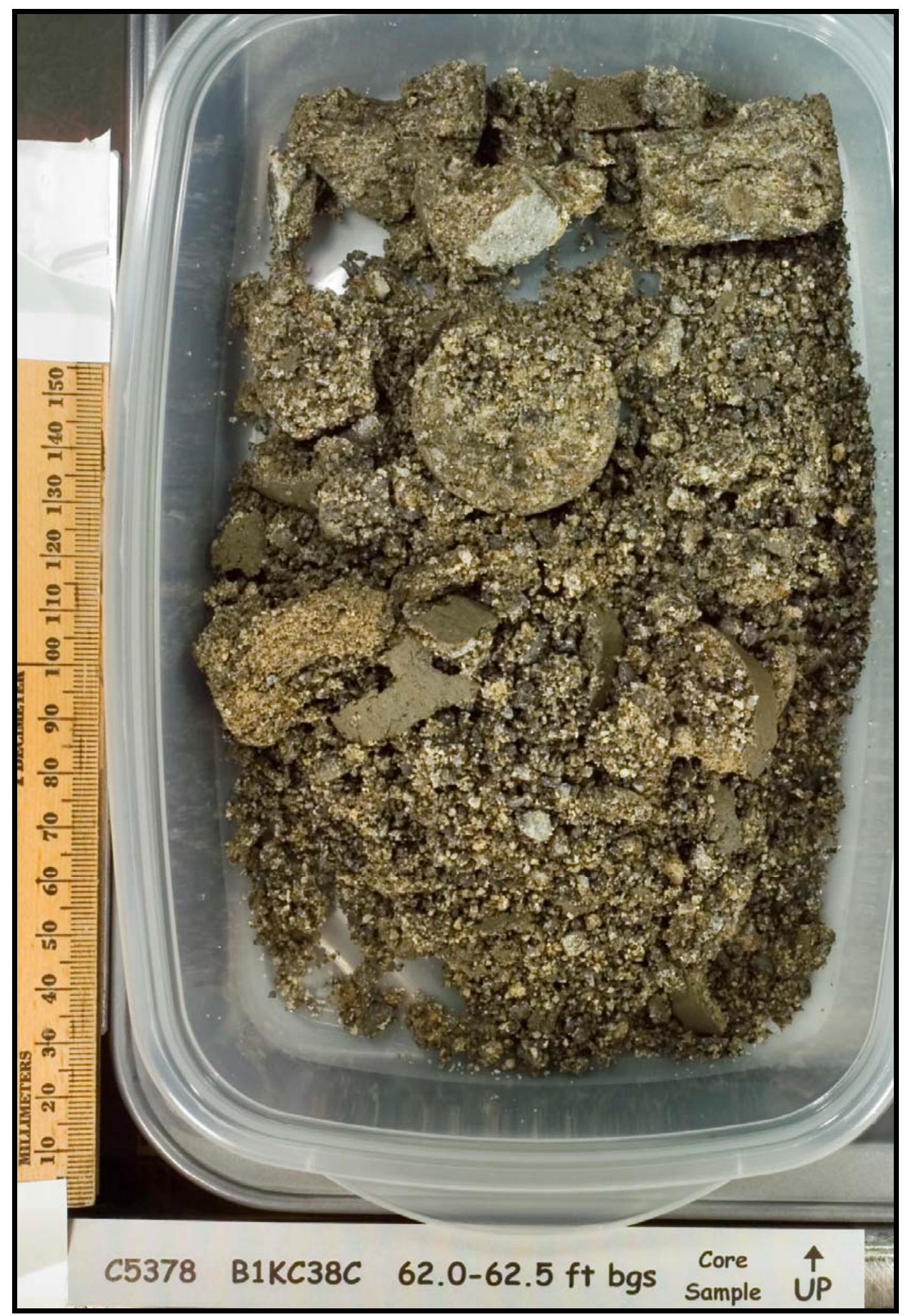

Figure C.14. Sample B1KC38B from Direct-Push Vertical Borehole C5378 


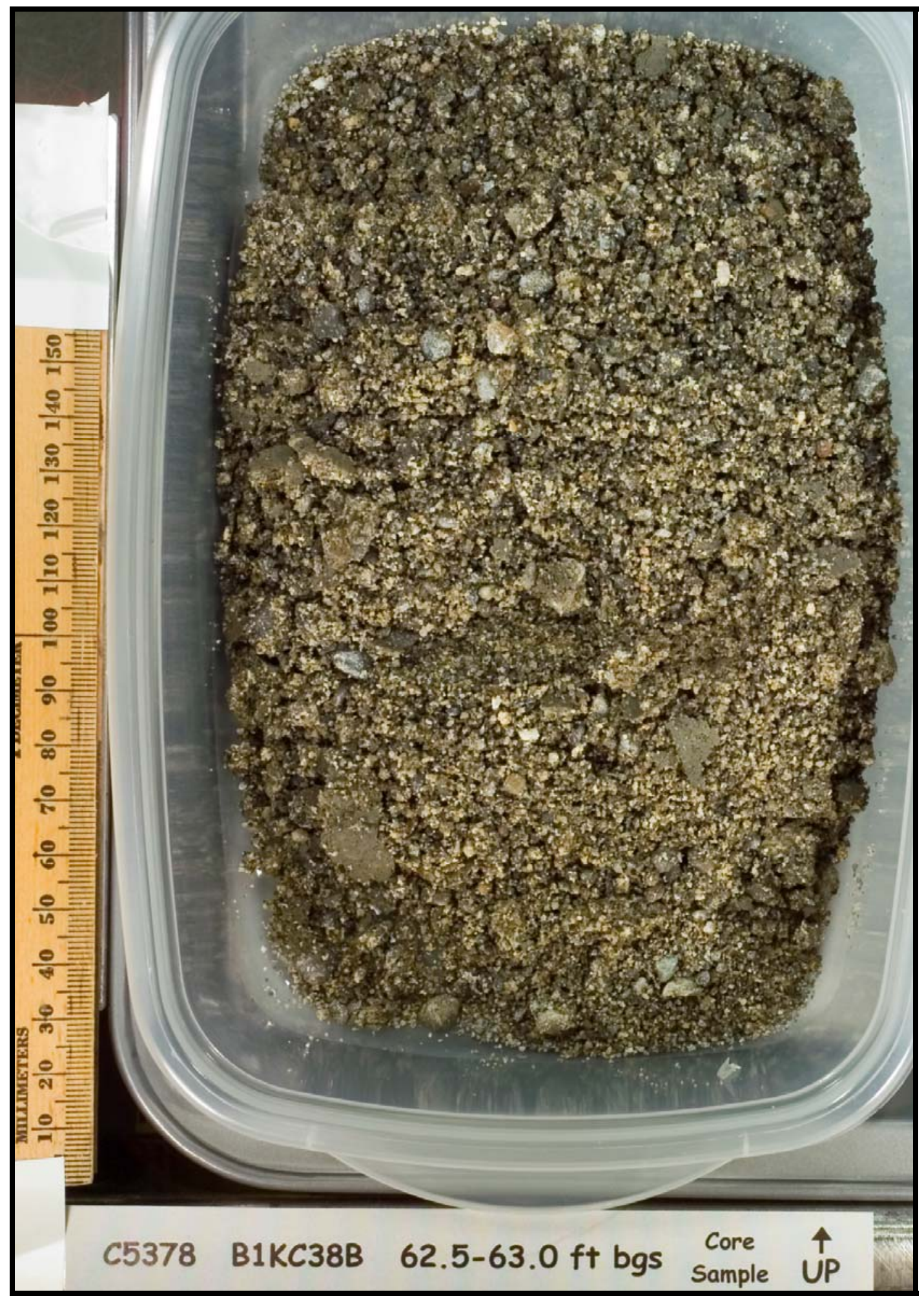

Figure C.15. Sample B1KC38B from Direct-Push Vertical Borehole C5378 


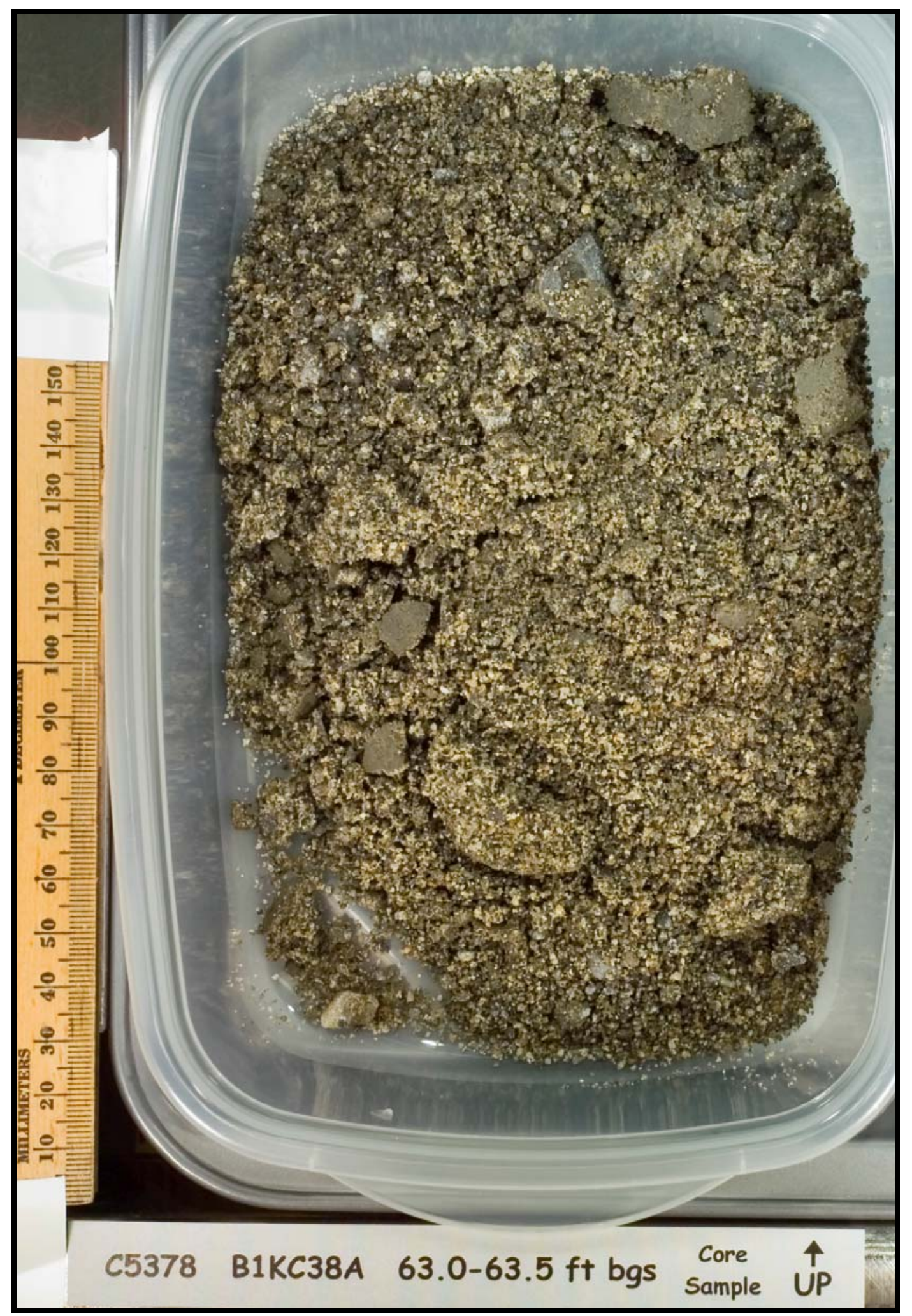

Figure C.16. Sample B1KC38A from Direct-Push Vertical Borehole C5378 


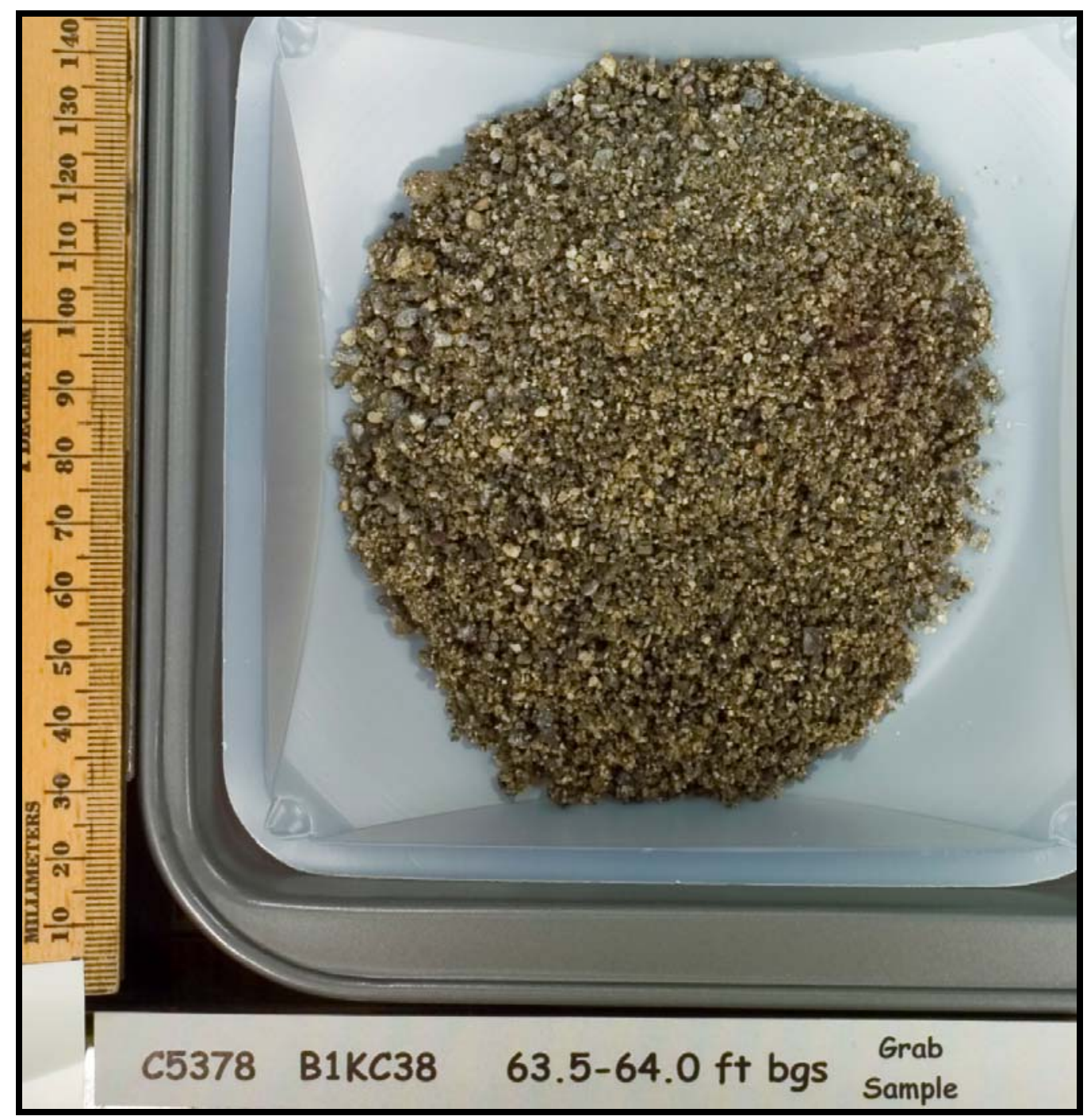

Figure C.17. Sample B1KC38 from Direct-Push Vertical Borehole C5378 


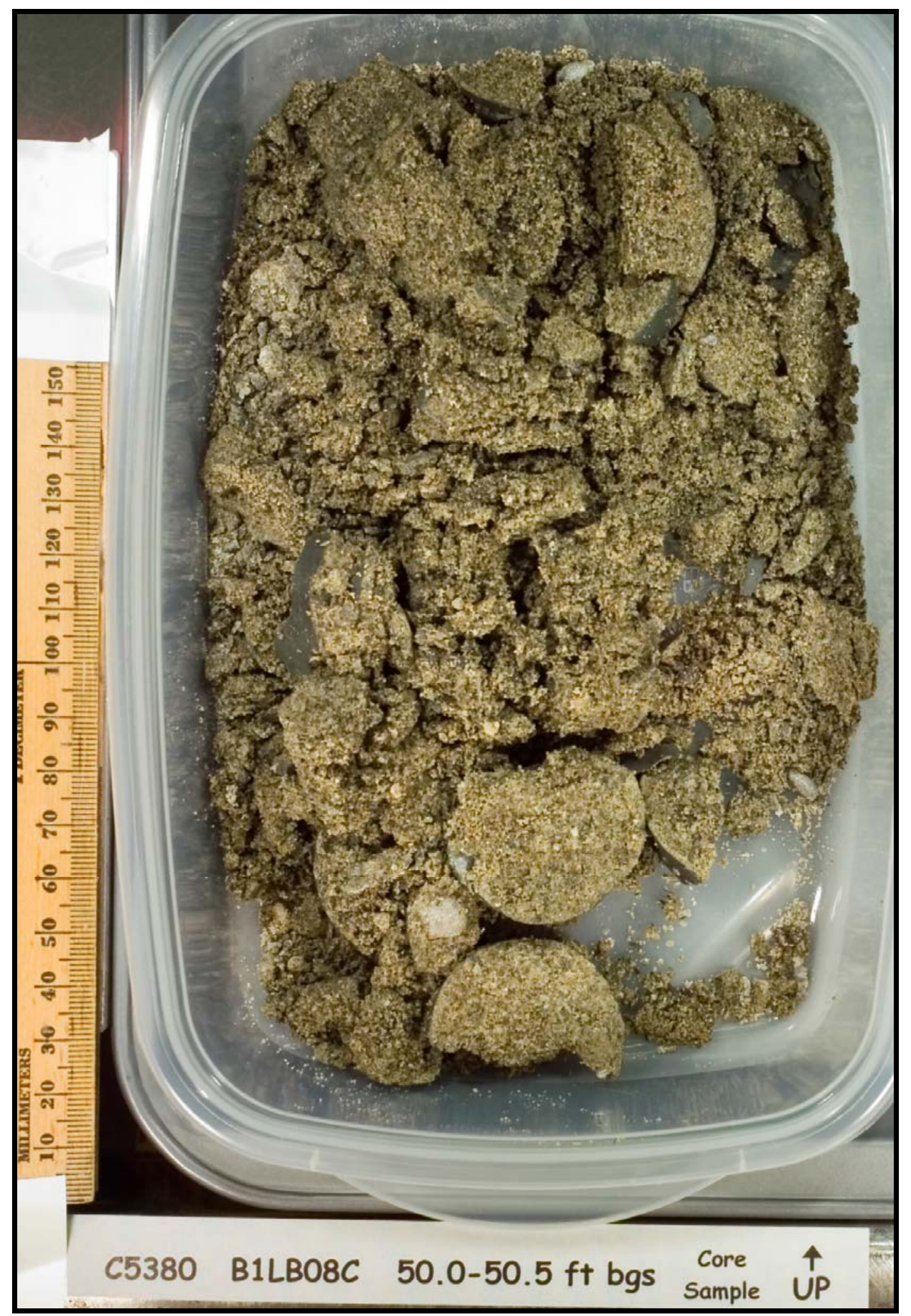

Figure C.18. Sample B1LB08C from Direct-Push Vertical Borehole C5380 


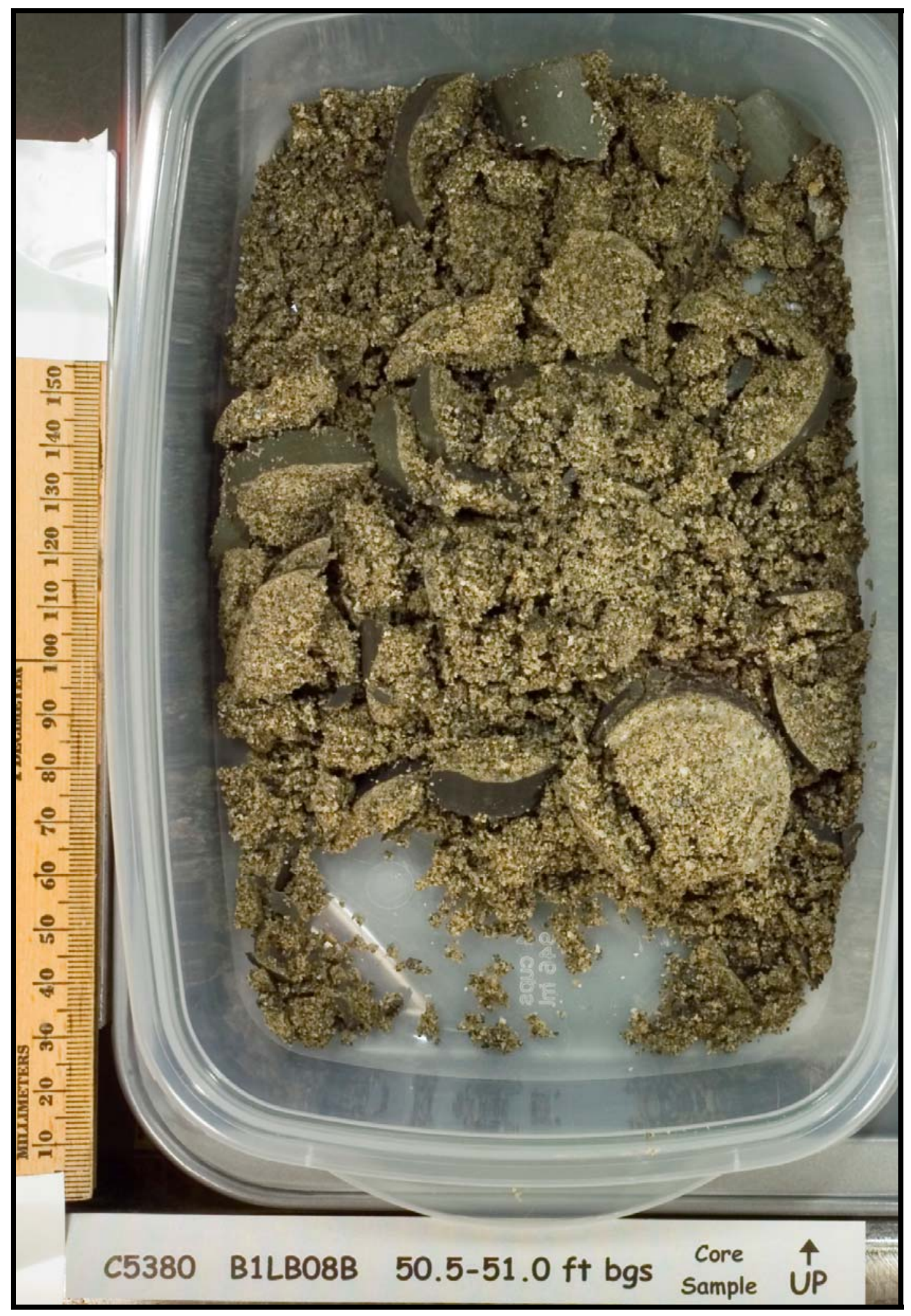

Figure C.19. Sample B1LB08B from Direct-Push Vertical Borehole C5380 


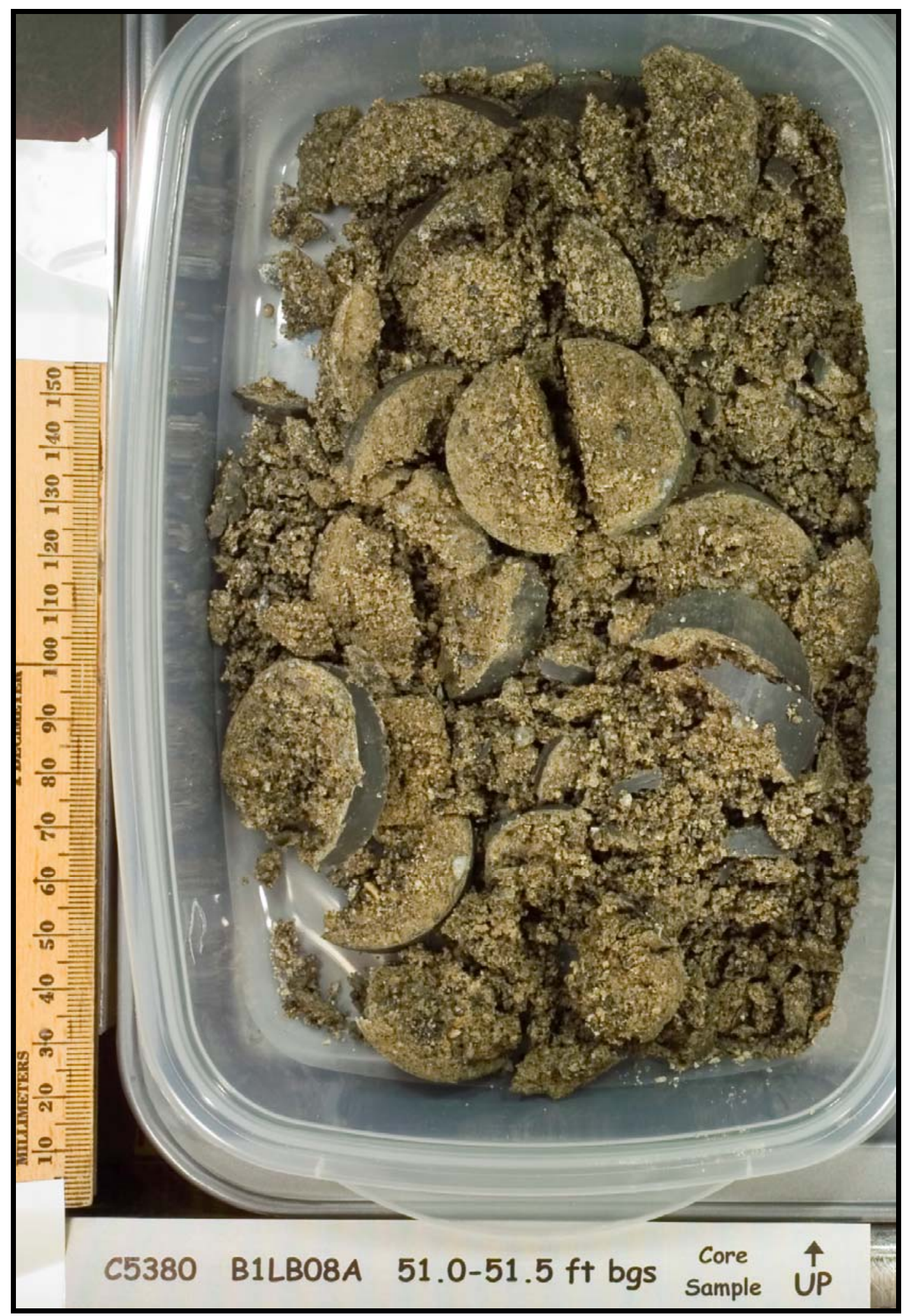

Figure C.20. Sample B1LB08A from Direct-Push Vertical Borehole C5380 


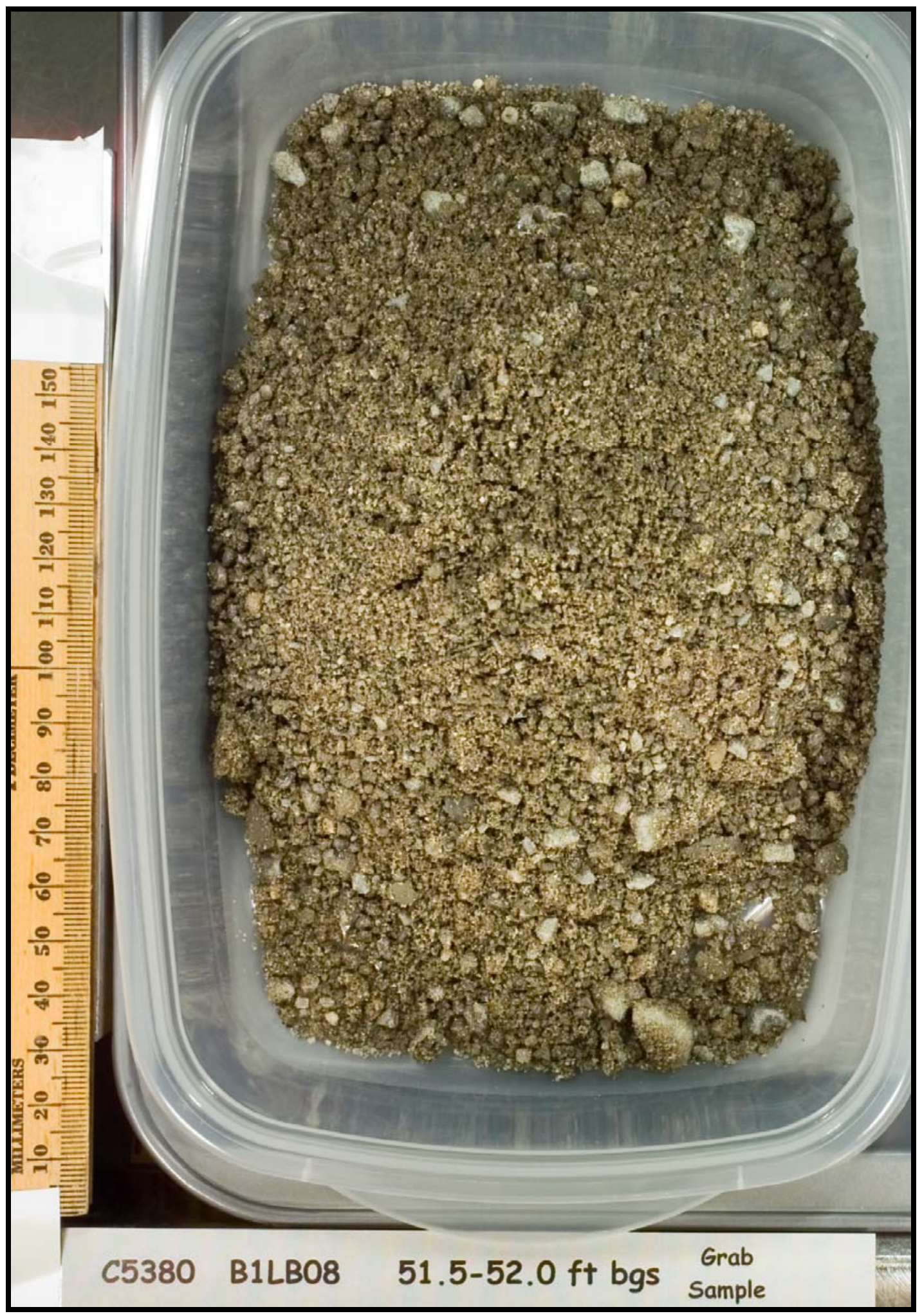

Figure C.21. Sample B1LB08 from Direct-Push Vertical Borehole C5380 


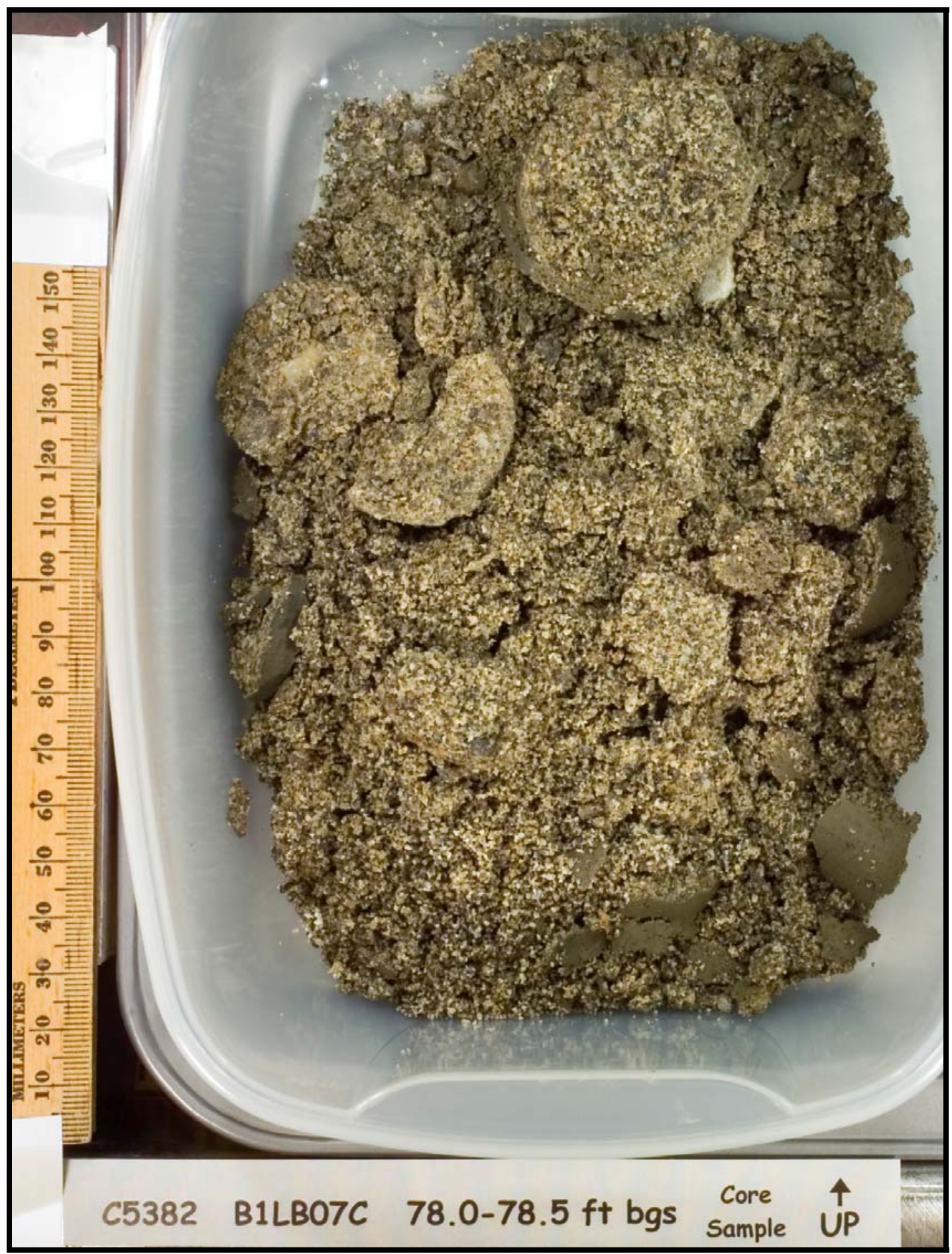

Figure C.22. Sample B1LB07C from Direct-Push Vertical Borehole C5382 


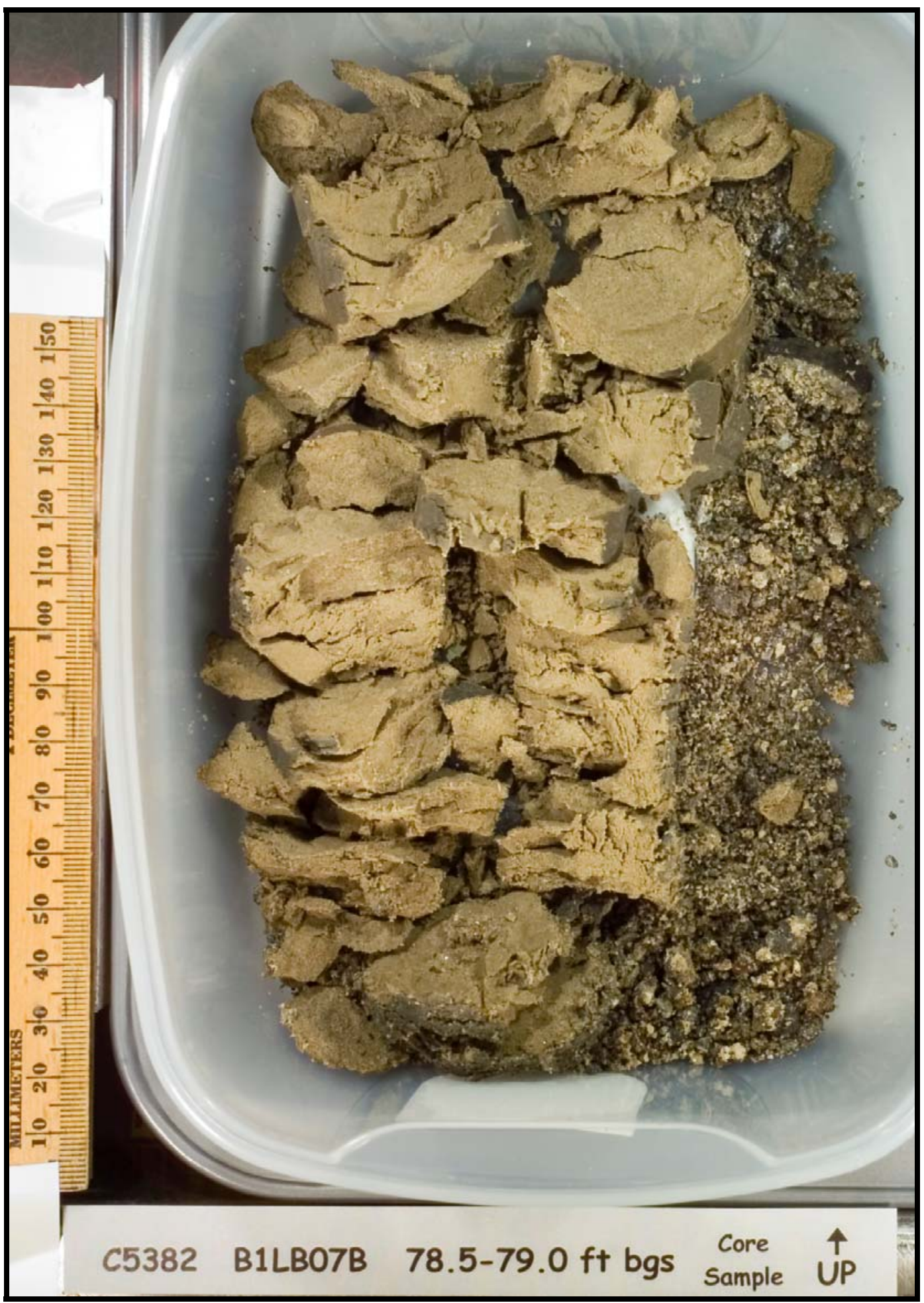

Figure C.23. Sample B1LB07B from Direct-Push Vertical Borehole C5382 


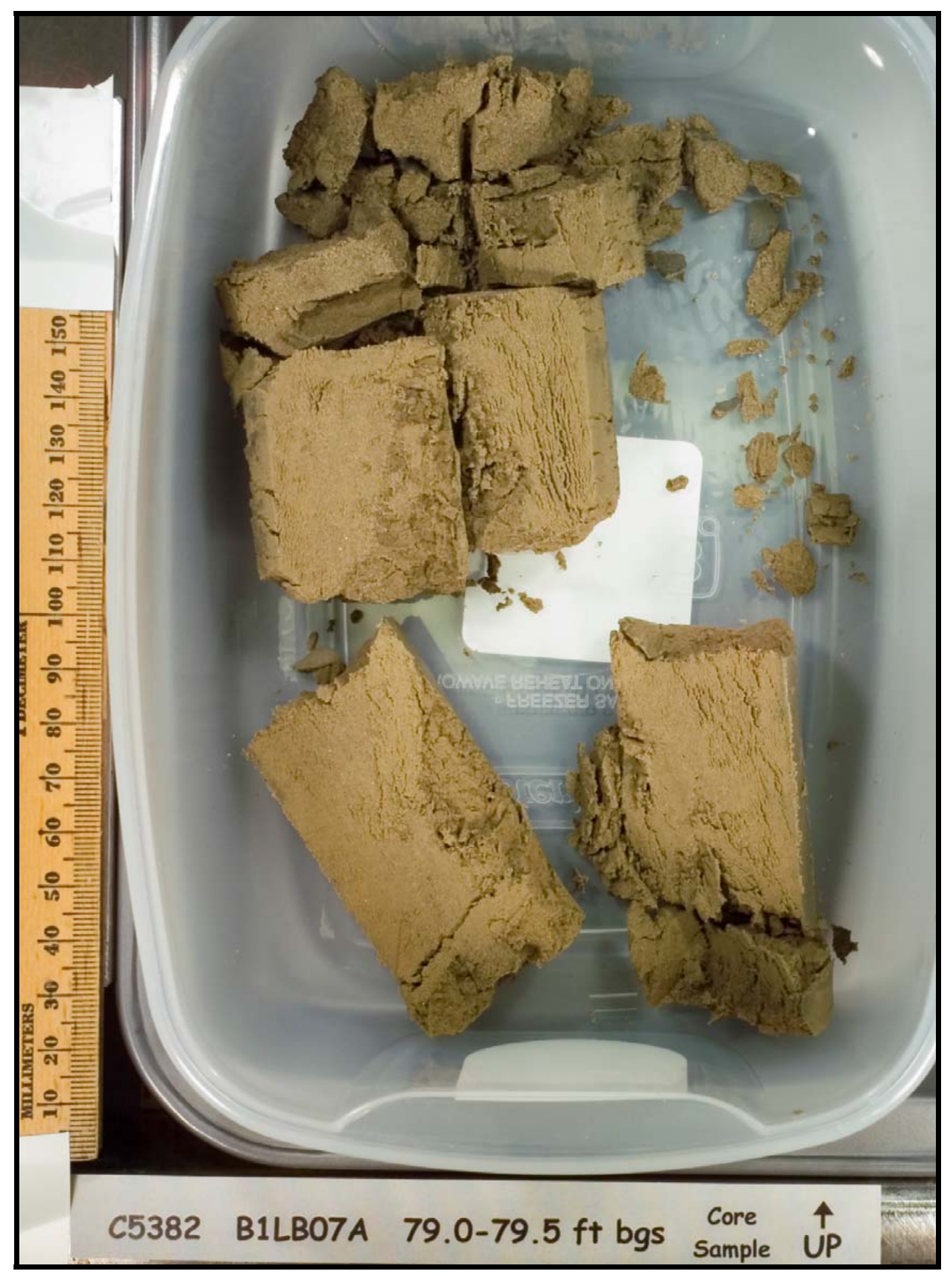

Figure C.24. Sample B1LB07A from Direct-Push Vertical Borehole C5382 


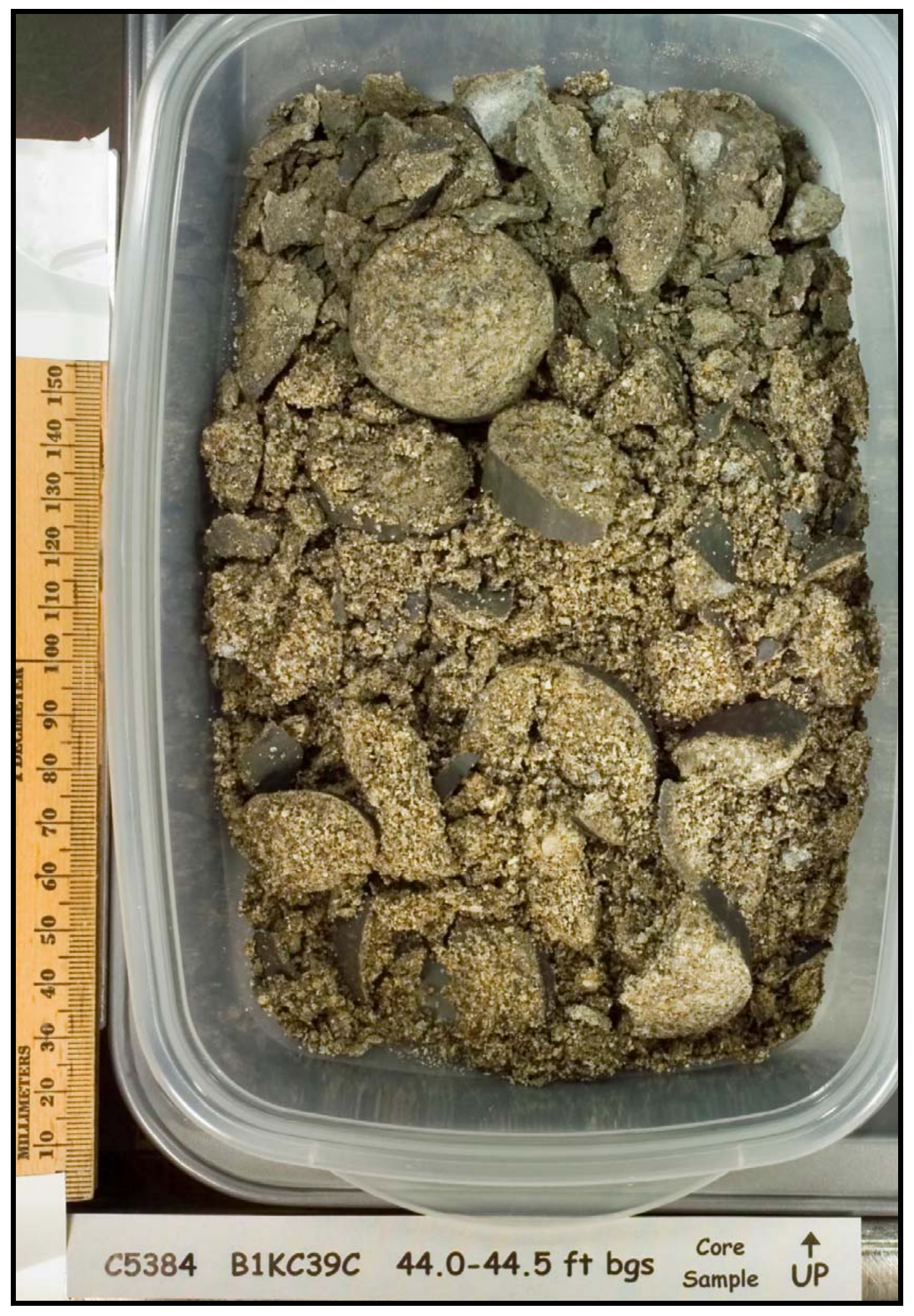

Figure C.25. Sample B1KC39C from Direct-Push Vertical Borehole C5384 


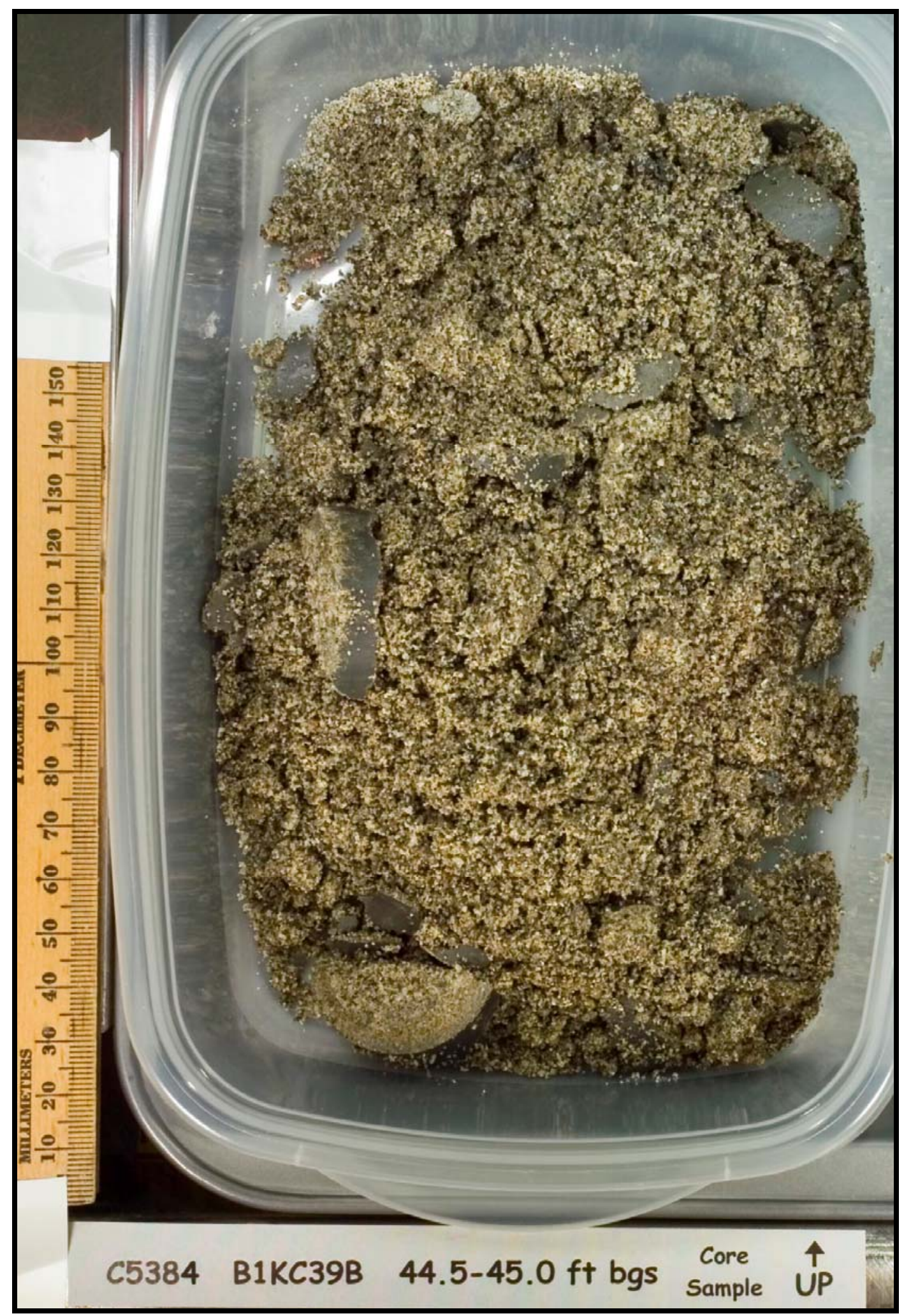

Figure C.26. Sample B1KC39B from Direct-Push Vertical Borehole C5384 


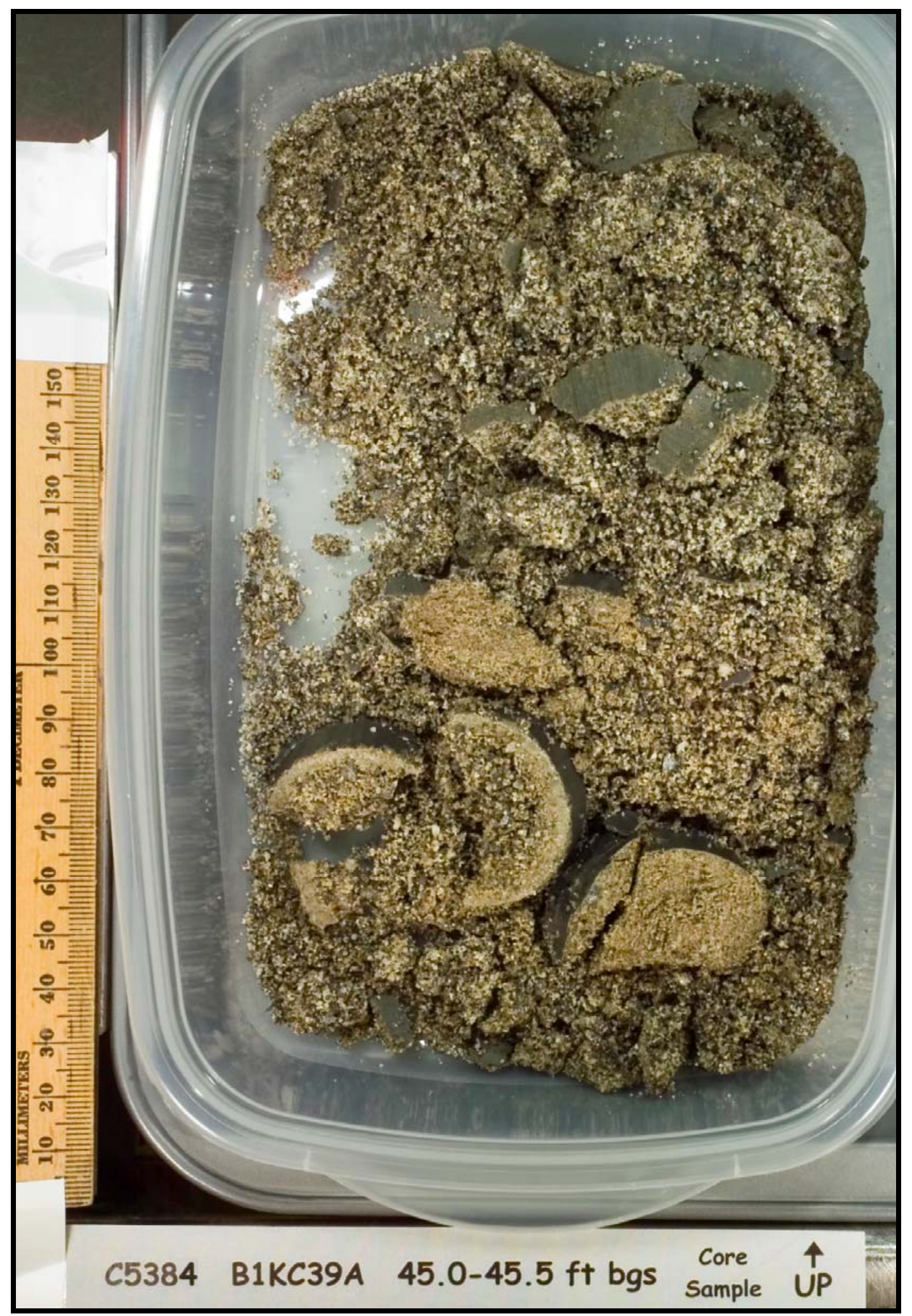

Figure C.27. Sample B1KC39A from Direct-Push Vertical Borehole C5384 


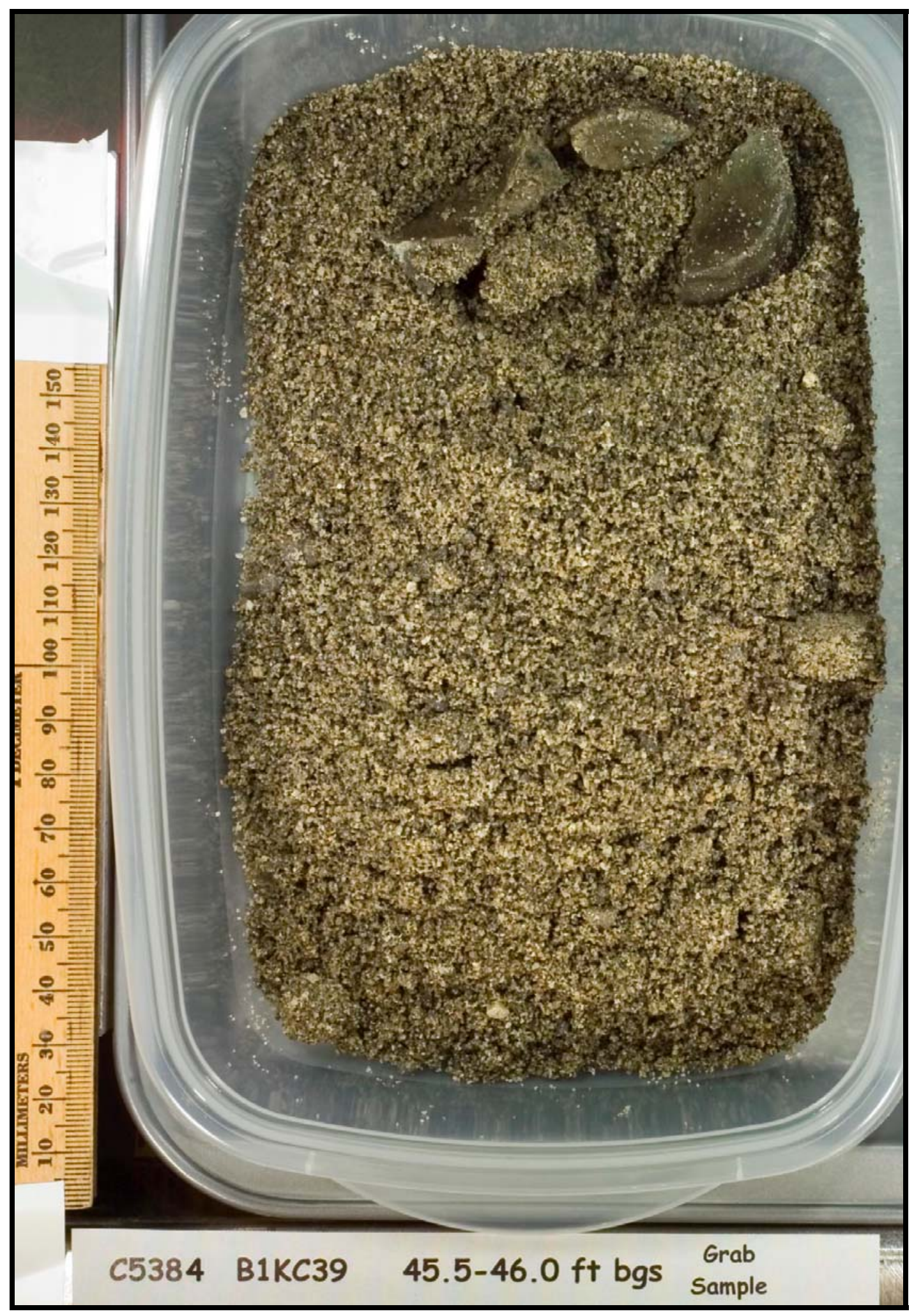

Figure C.28. Sample B1KC39 from Direct-Push Vertical Borehole C5384 



\section{Appendix D}

Logs of Core and Grab Samples from the Direct Push Boreholes in the Vicinity of Single Shell Tanks 241-T-101 and 241-T-104 



\section{Appendix D}

\section{Logs of Core and Grab Samples from the Direct Push Boreholes in the Vicinity of Single Shell Tanks 241-T-101 and 241-T-104}

D.1 Core Log for Direct-Push Vertical Borehole C4596.................................................... D.2

D.2 Core Log for Direct-Push Vertical Borehole C4598 …................................................... D.

D.3 Core Log for Direct-Push Vertical Borehole C5374 ....................................................... D.4

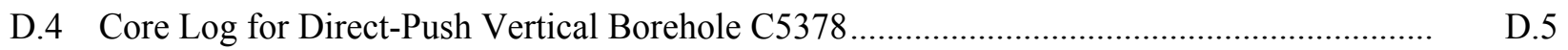

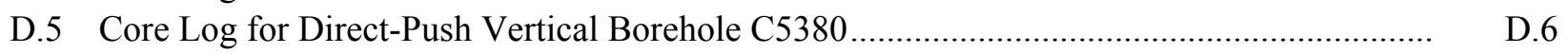

D.6 Core Log for Direct-Push Vertical Borehole C5382 …...................................................... D.

D.7 Core Log for Direct-Push Vertical Borehole C5384 .......................................................... D.8 


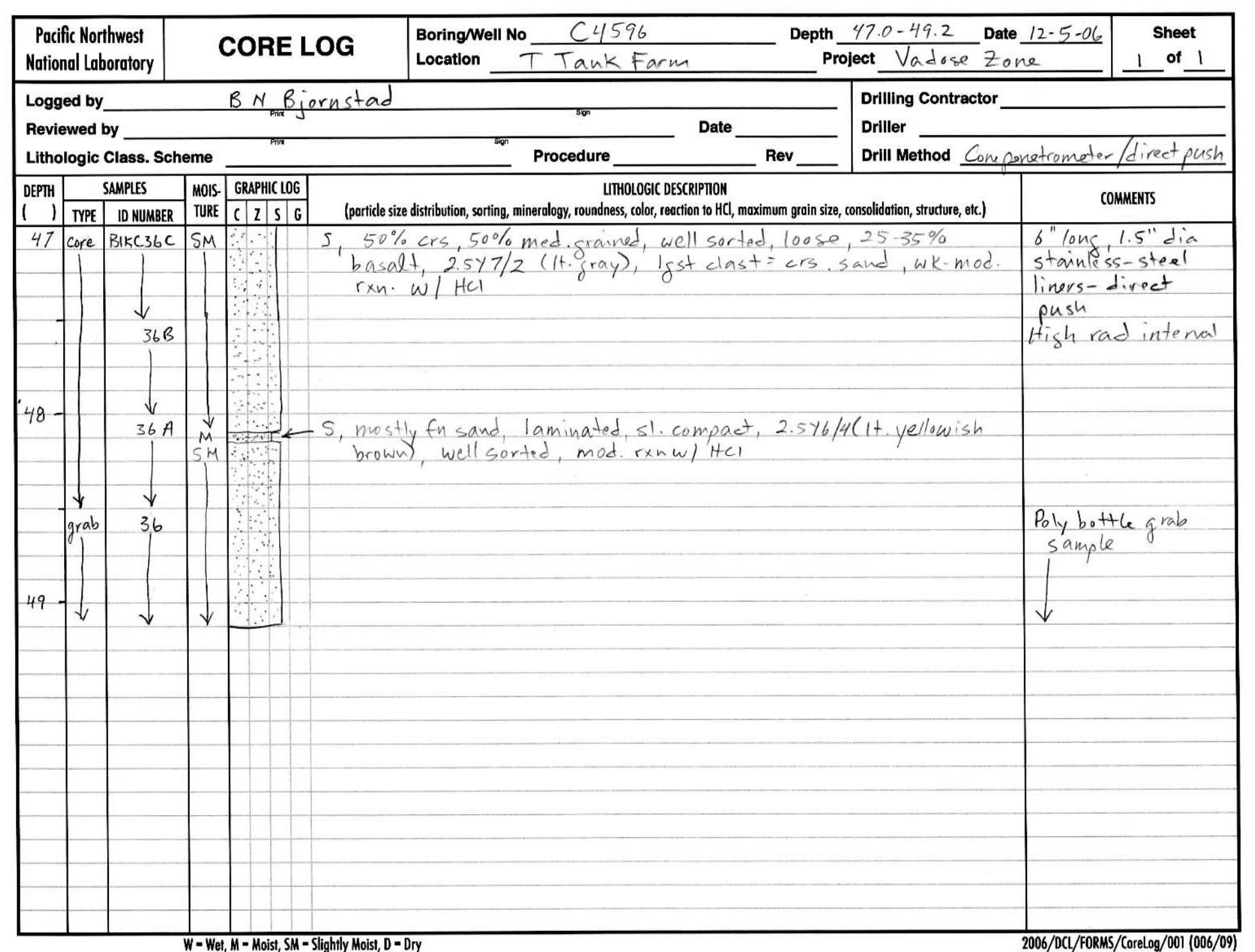

Figure D.1. Core Log for Direct-Push Vertical Borehole C4596 


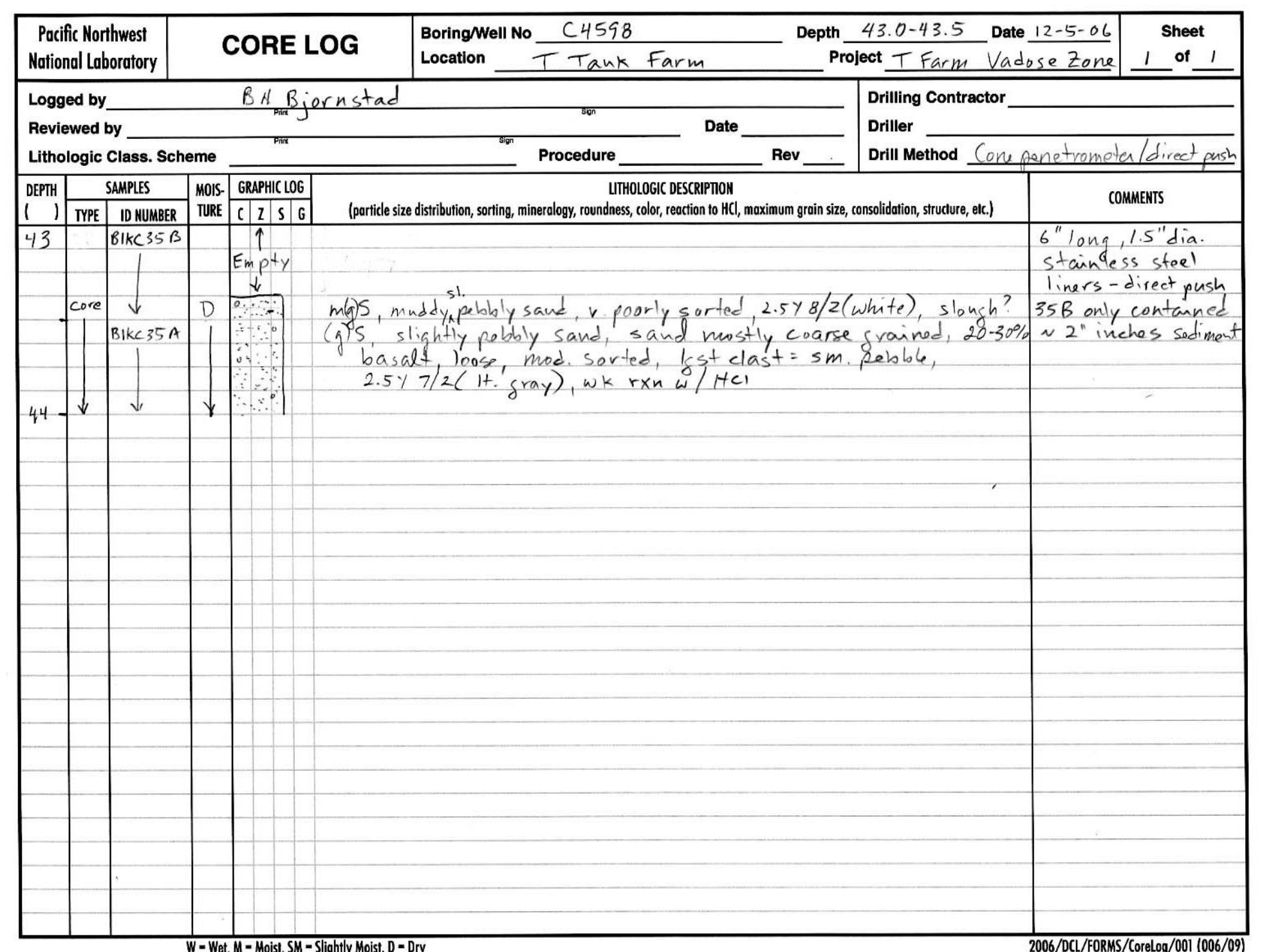

Figure D.2. Core Log for Direct-Push Vertical Borehole C4598 


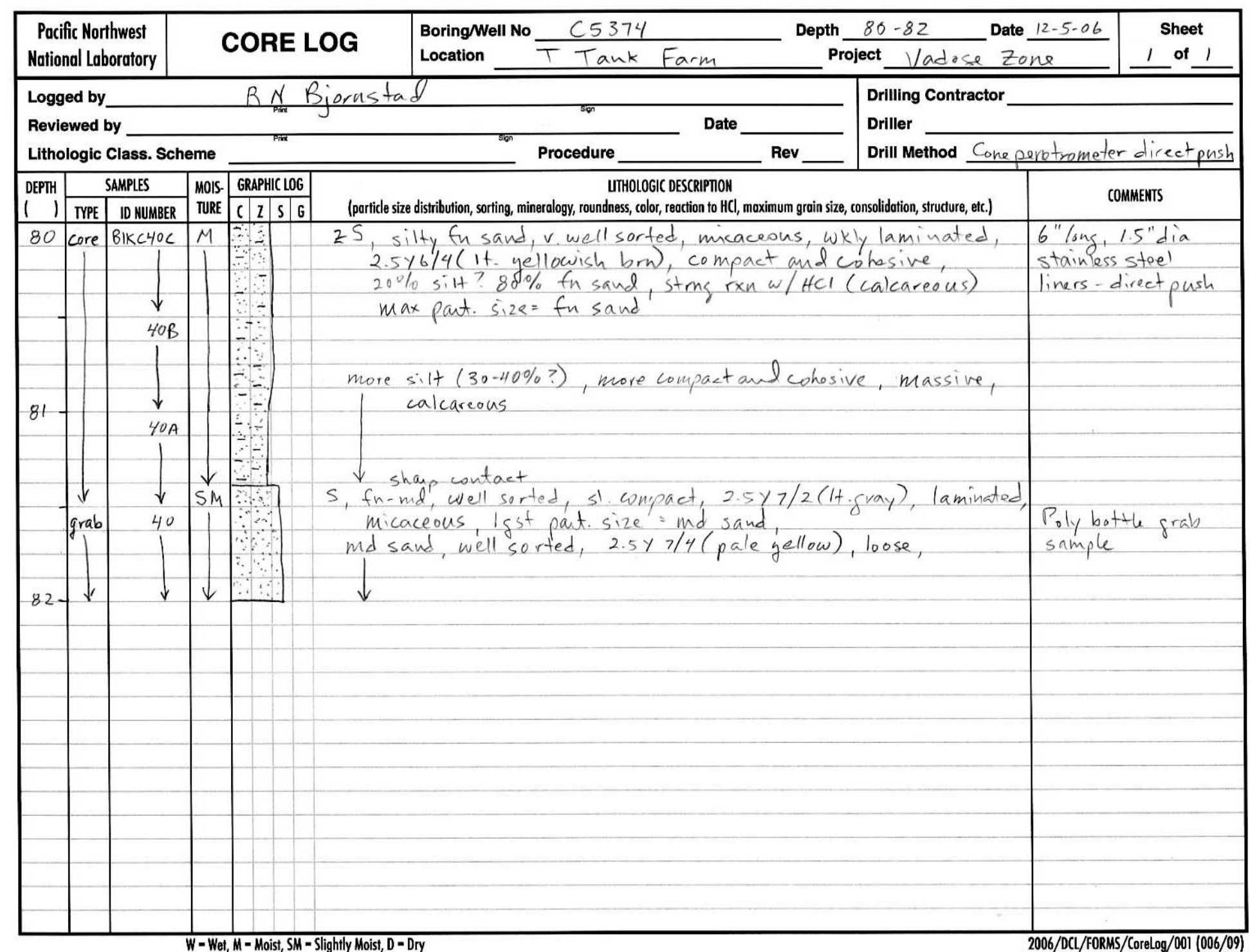

Figure D.3. Core Log for Direct-Push Vertical Borehole C5374 


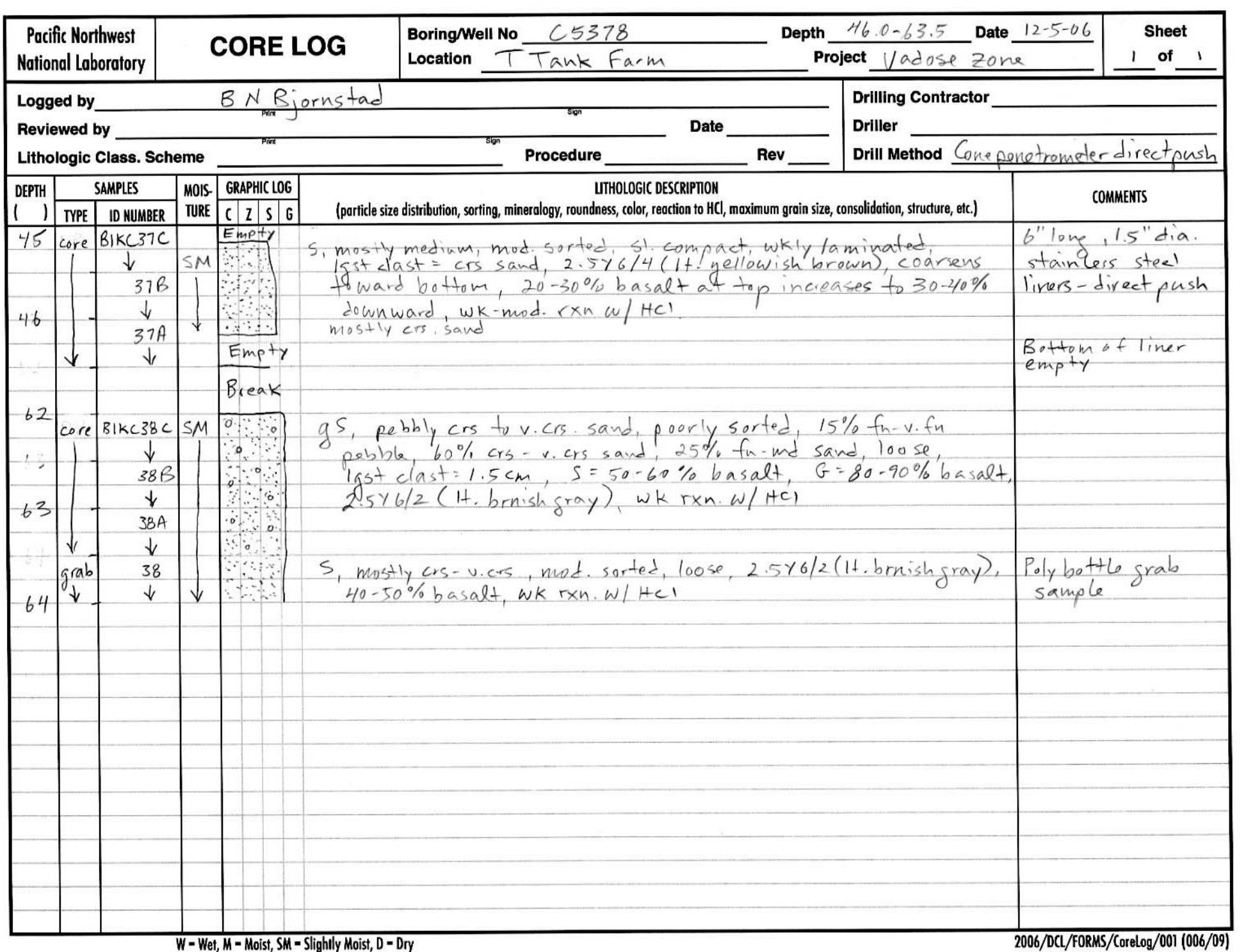

Figure D.4. Core Log for Direct-Push Vertical Borehole C5378 


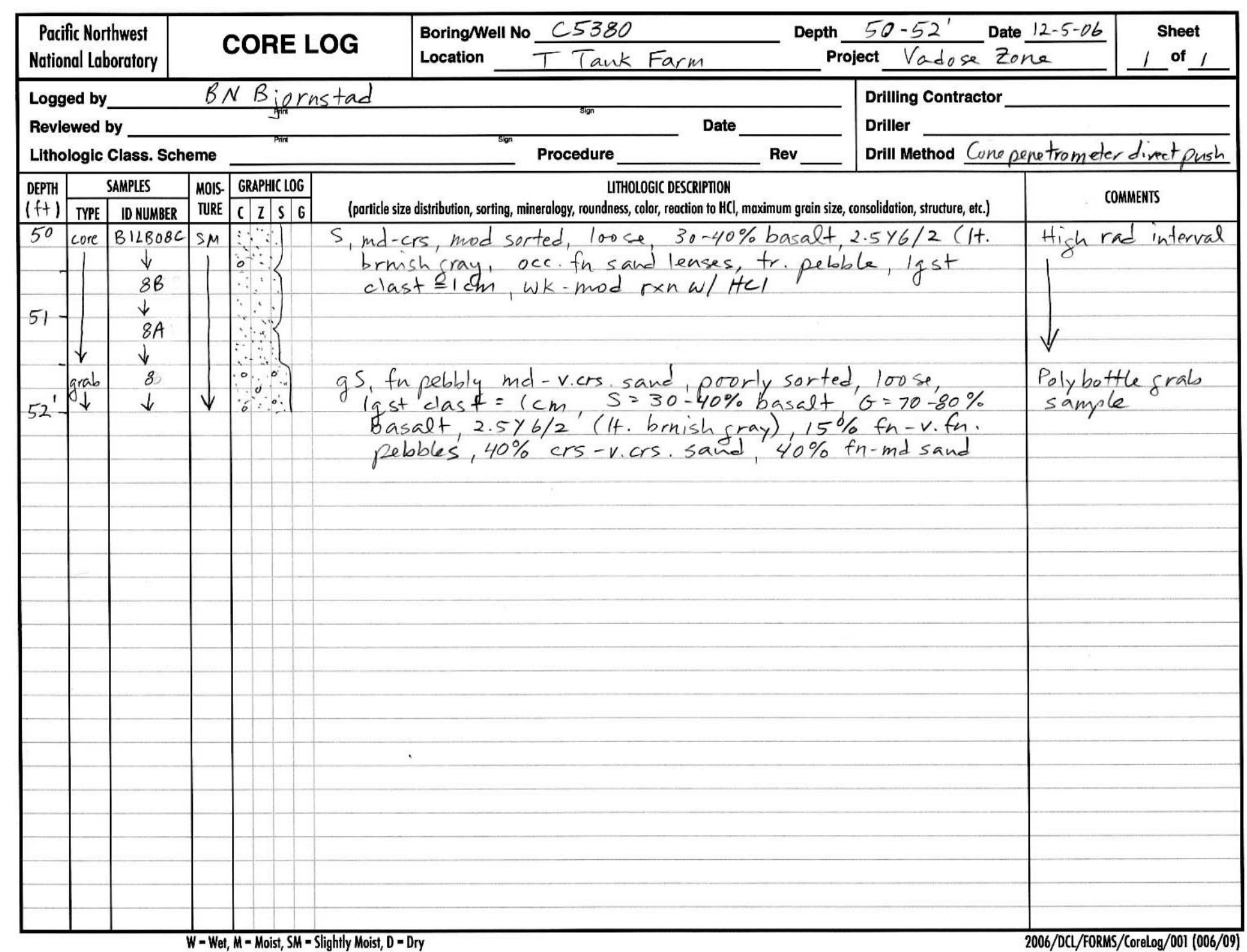

Figure D.5. Core Log for Direct-Push Vertical Borehole C5380 


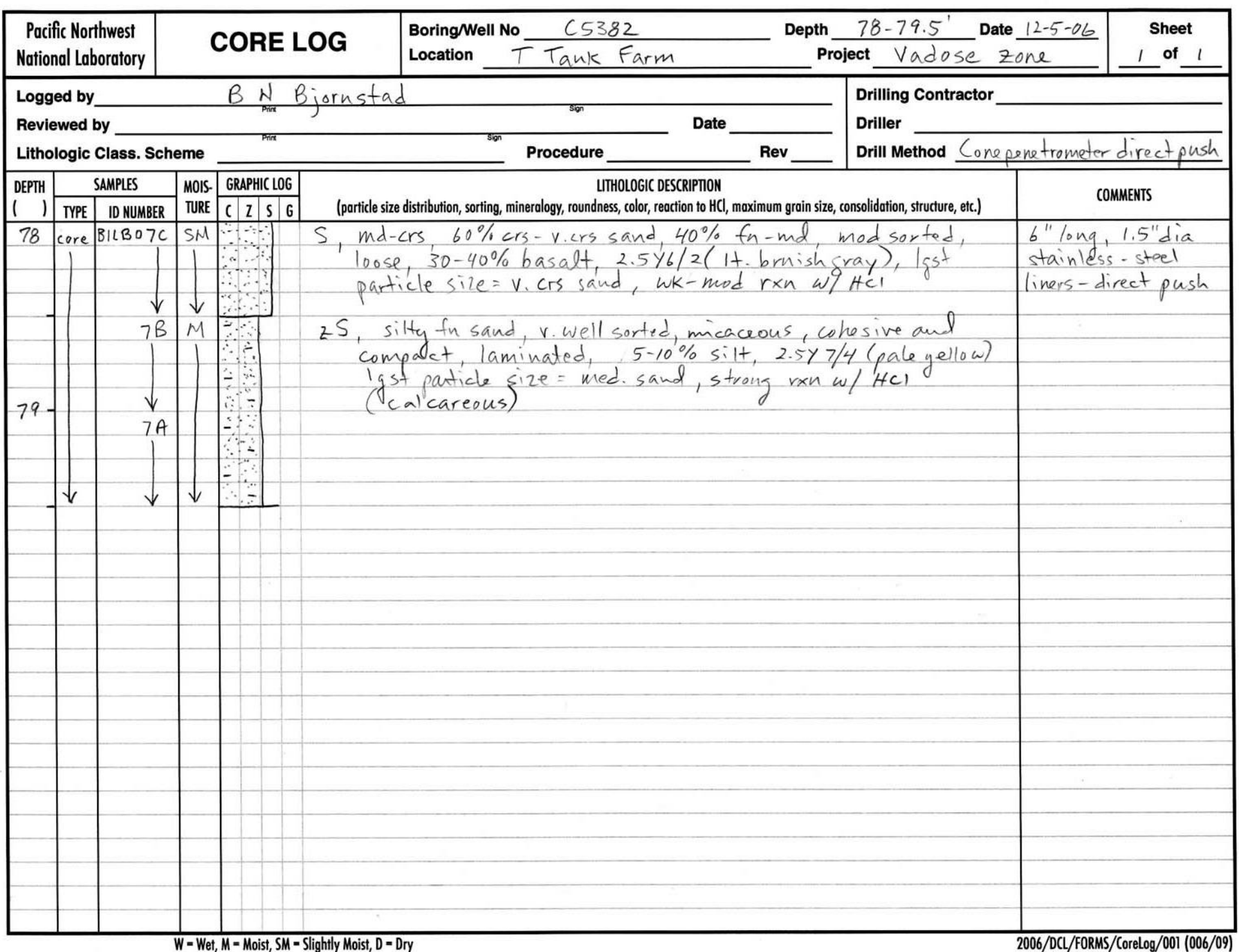

Figure D.6. Core Log for Direct-Push Vertical Borehole C5382 


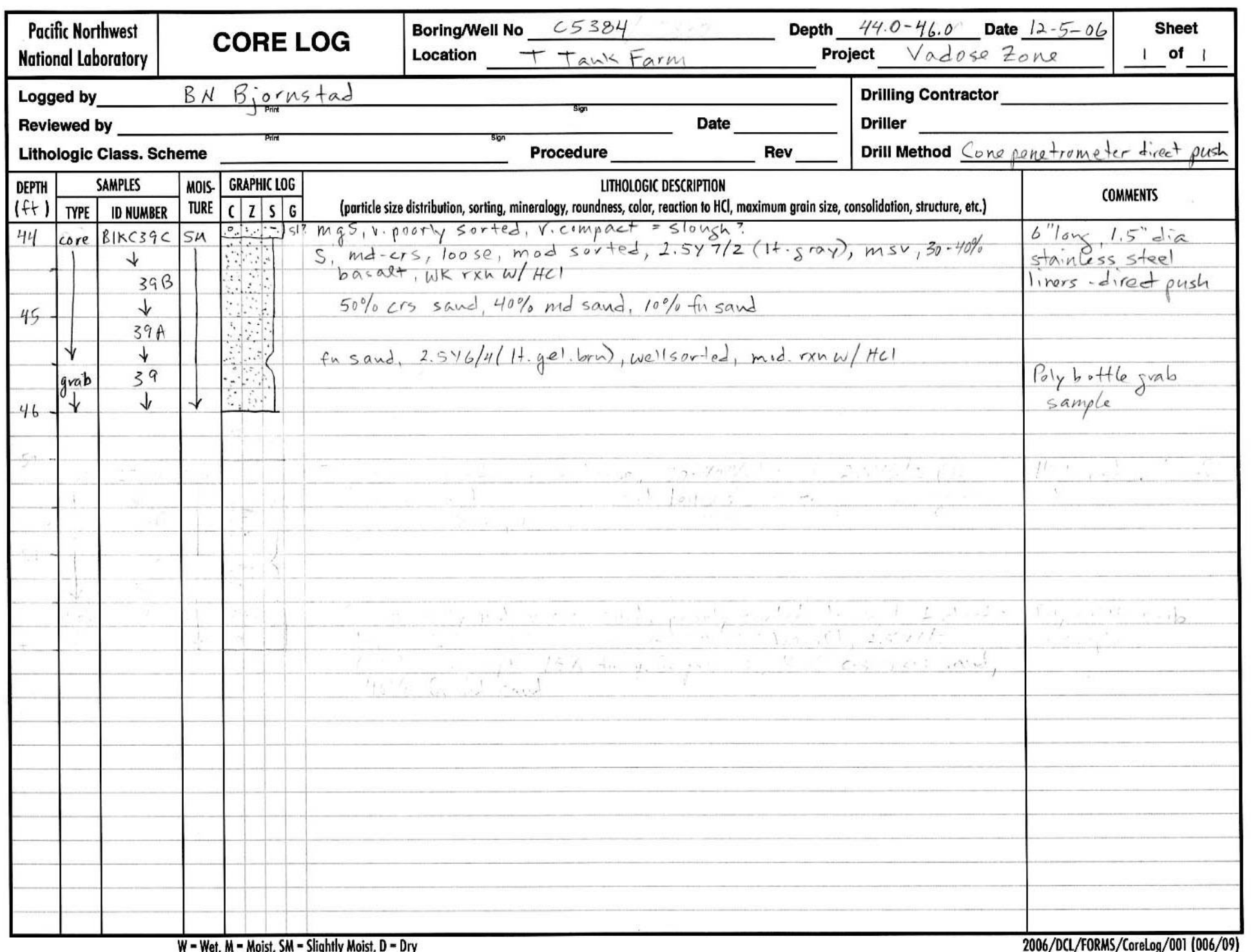

Figure D.7. Core Log for Direct-Push Vertical Borehole C5384 


\section{Appendix E}

Photographs of Core and Grab Samples from the Interim Measures Direct Push Boreholes Collected North of the T Tank Farm 



\section{Appendix E}

\section{Photographs of Core and Grab Samples from the Interim Measures Direct Push Boreholes Collected North of the T Tank Farm}

E.1 Sample B1NP87 from Direct-Push Vertical Borehole C5692 ......................................... E.2

E.2 Sample B1NP87A from Direct-Push Vertical Borehole C5692 ….................................... E.

E.3 Sample B1NP87B from Direct-Push Vertical Borehole C5692 …....................................... E. 4

E.4 Sample B1NP87C from Direct-Push Vertical Borehole C5692 …........................................ E.

E.5 Sample B1NP90 from Direct-Push Vertical Borehole C5694 ............................................ E. 6

E.6 Sample B1NP90A from Direct-Push Vertical Borehole C5694 …....................................... E.

E.7 Sample B1NP90B from Direct-Push Vertical Borehole C5694 _......................................... E.

E.8 Sample B1NP90C from Direct-Push Vertical Borehole C5694 …..................................... E.9 


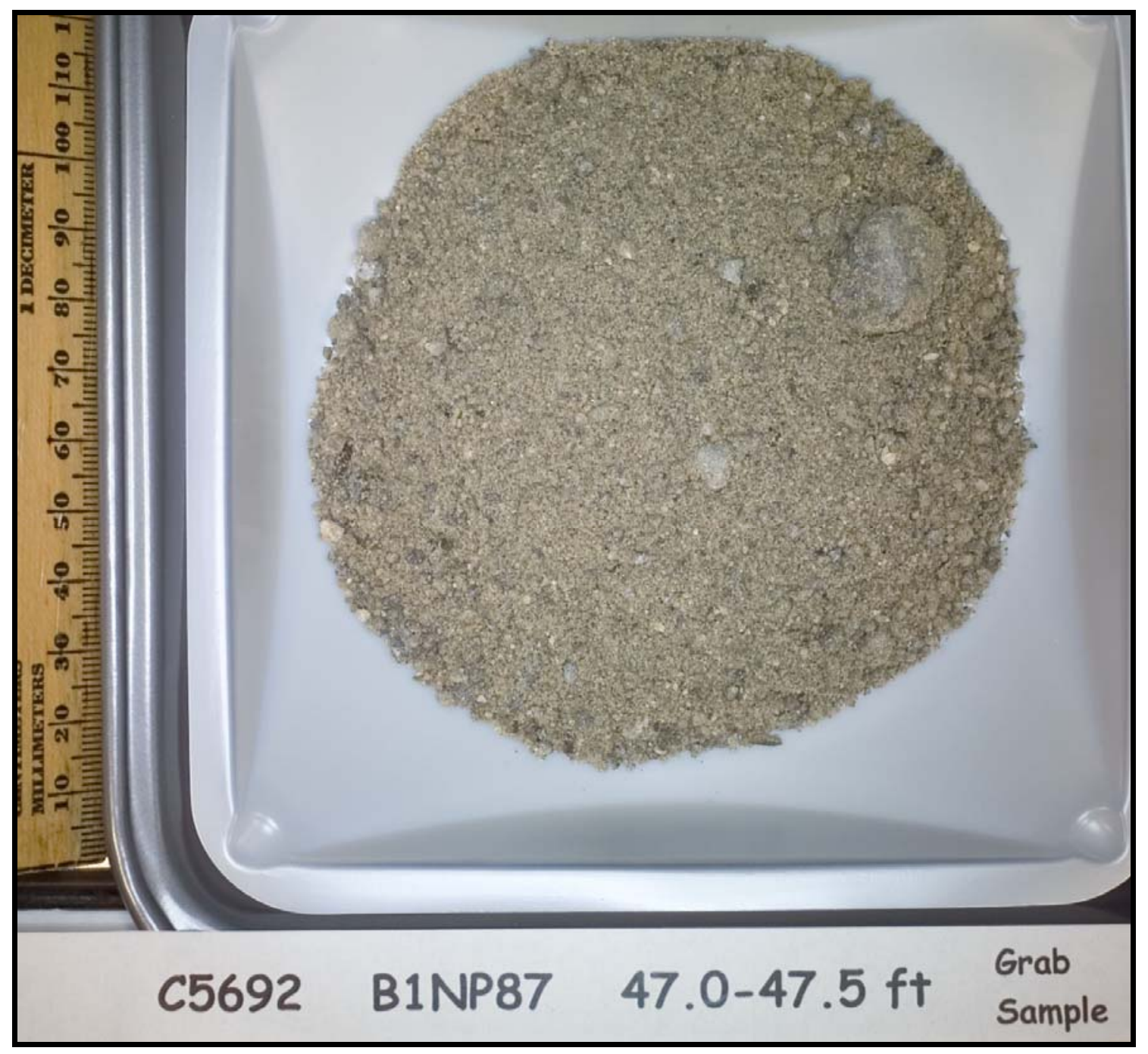

Figure E.1. Sample B1NP87 from Direct-Push Vertical Borehole C5692 


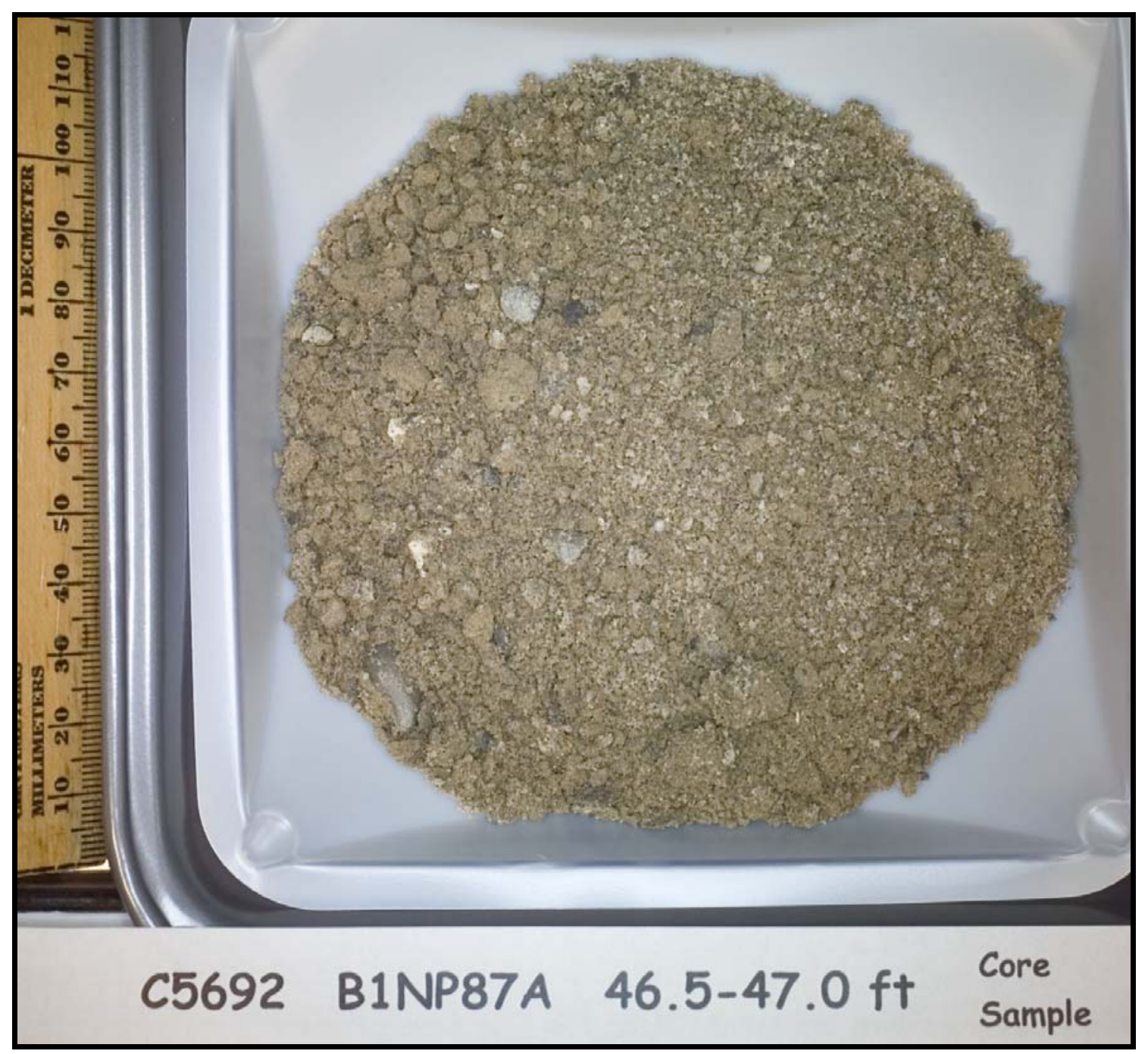

Figure E.2. Sample B1NP87A from Direct-Push Vertical Borehole C5692 


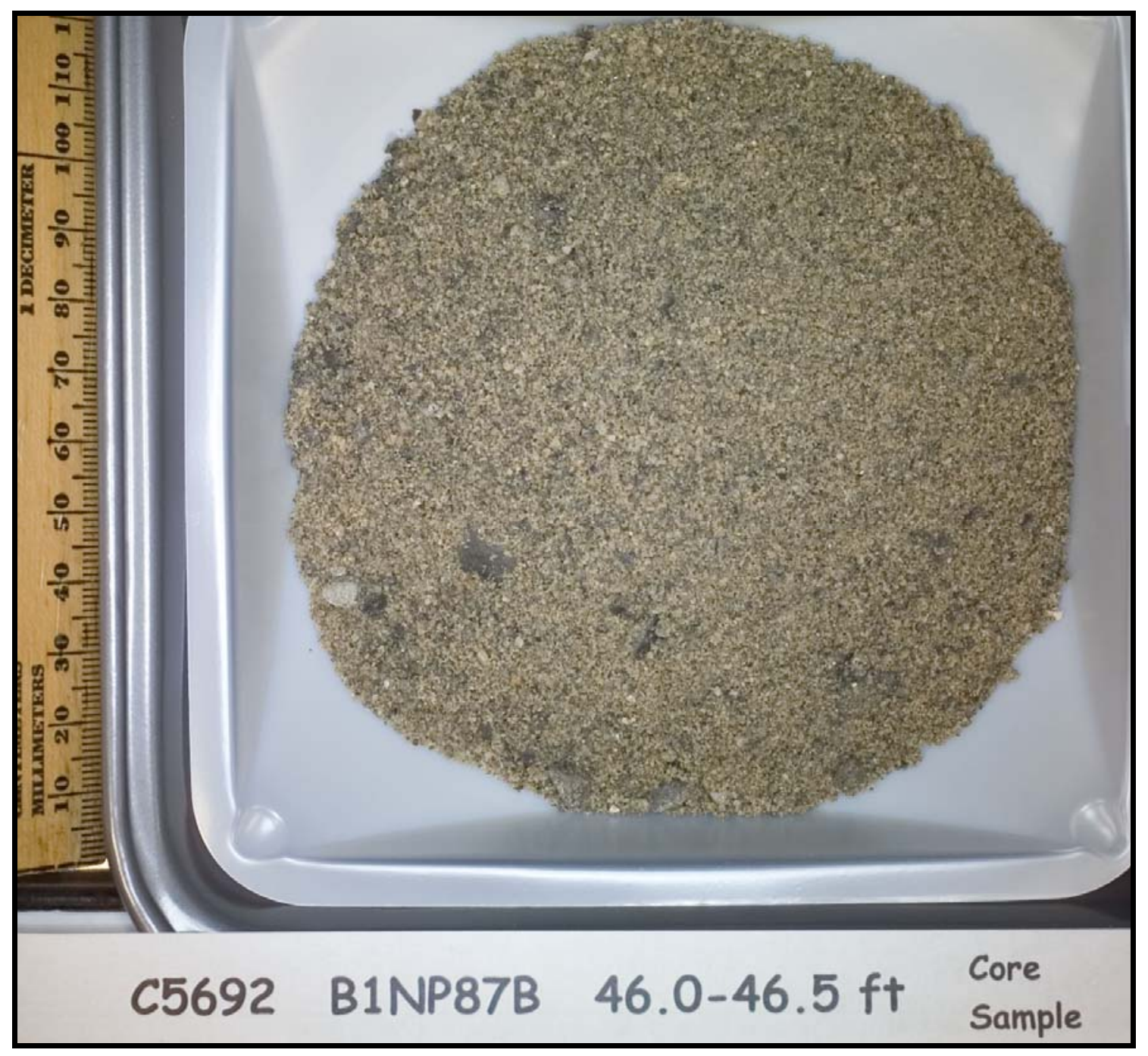

Figure E.3. Sample B1NP87B from Direct-Push Vertical Borehole C5692 


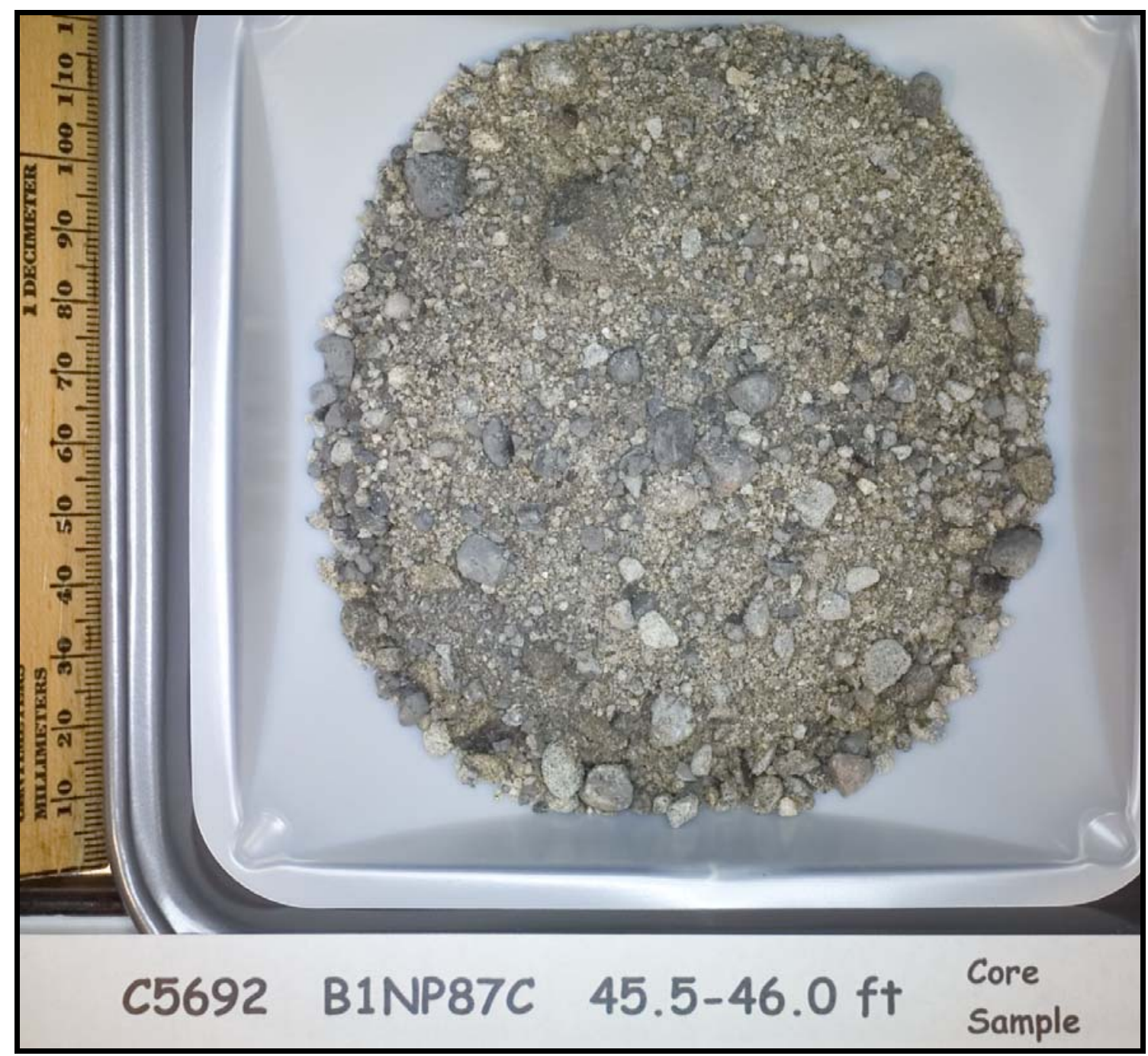

Figure E.4. Sample B1NP87C from Direct-Push Vertical Borehole C5692 


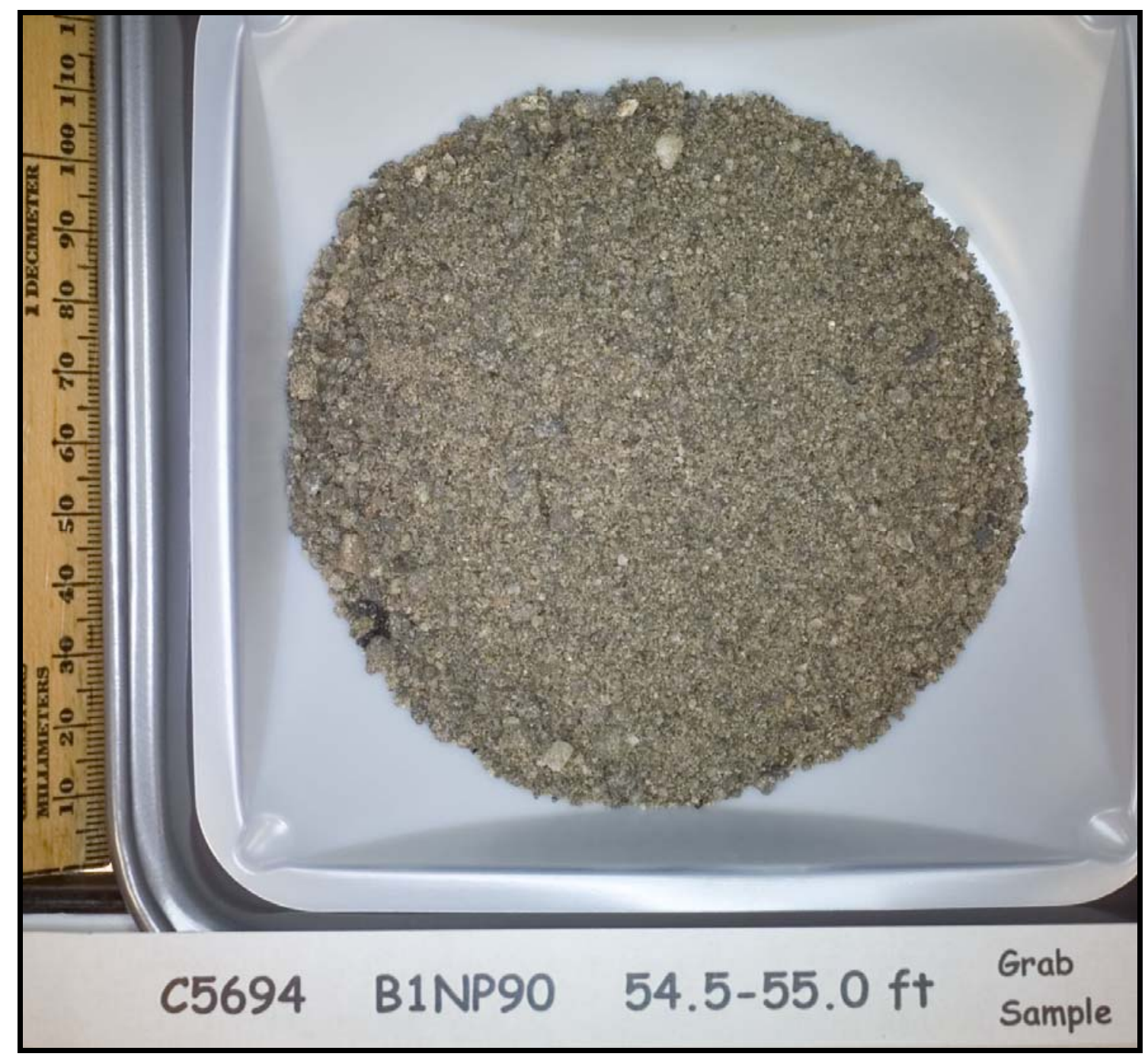

Figure E.5. Sample B1NP90 from Direct-Push Vertical Borehole C5694 


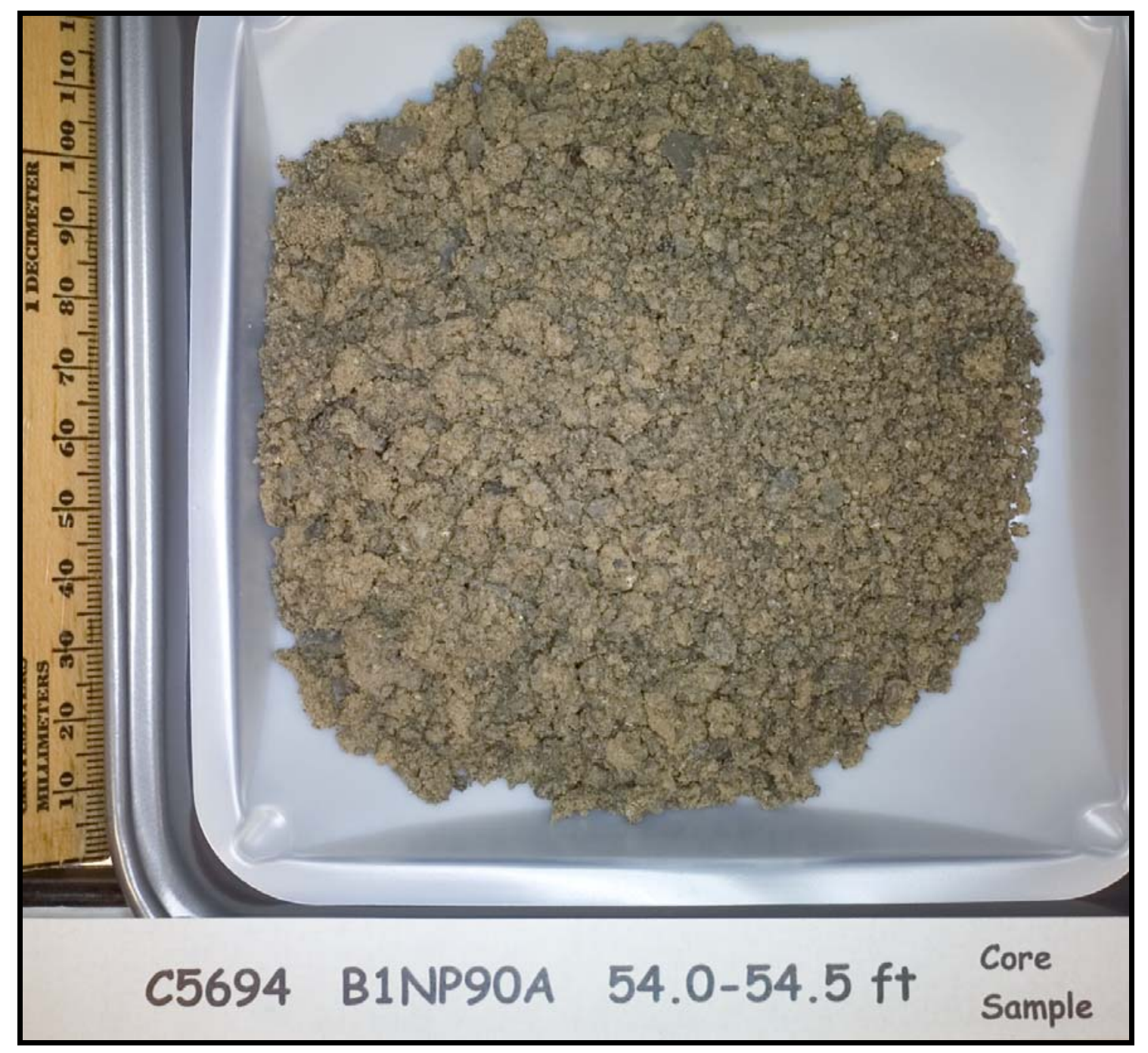

Figure E.6. Sample B1NP90A from Direct-Push Vertical Borehole C5694 


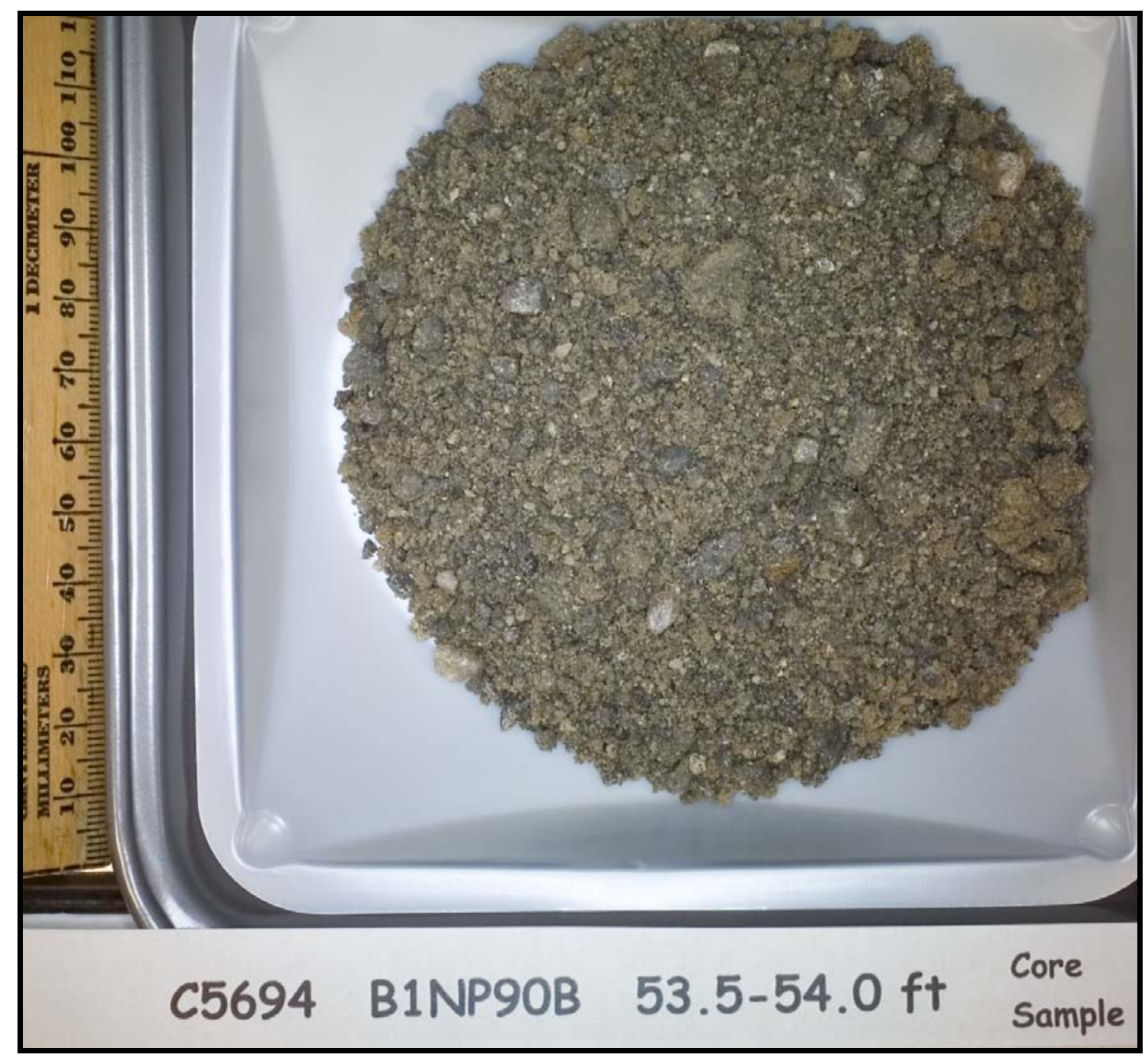

Figure E.7. Sample B1NP90B from Direct-Push Vertical Borehole C5694 


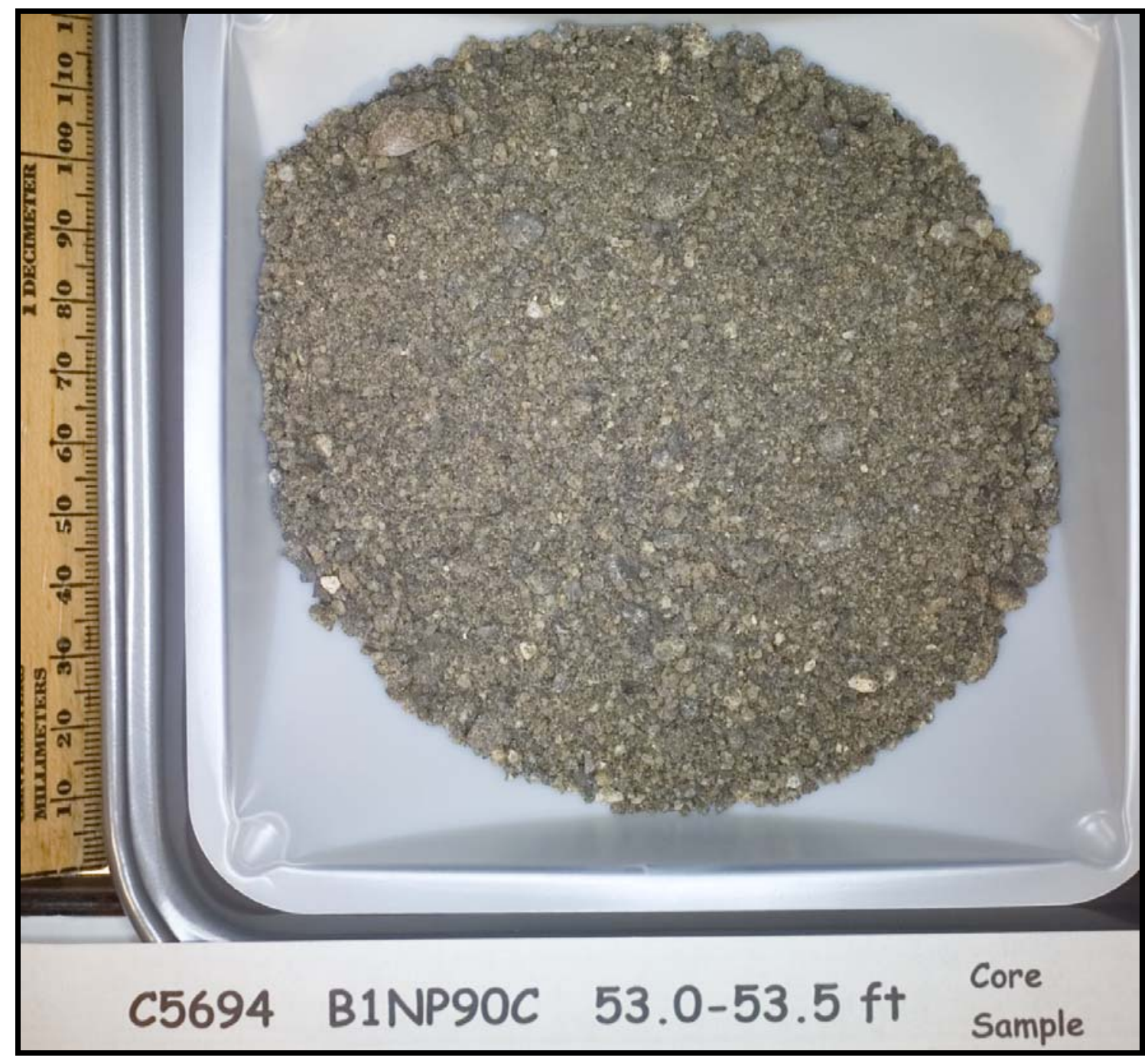

Figure E.8. Sample B1NP90C from Direct-Push Vertical Borehole C5694 



\section{Appendix F}

Logs of Core and Grab Samples from the Interim Measures Direct Push Boreholes Emplaced North of the T Tank Farm 



\section{Appendix F}

\section{Logs of Core and Grab Samples from the Interim Measures Direct Push Boreholes Emplaced North of the T Tank Farm}

F.1 Core Log for Direct-Push Vertical Borehole C5692 _..................................................... F.2

F.2 Core Log for Direct-Push Vertical Borehole C5694 …........................................................ F. 


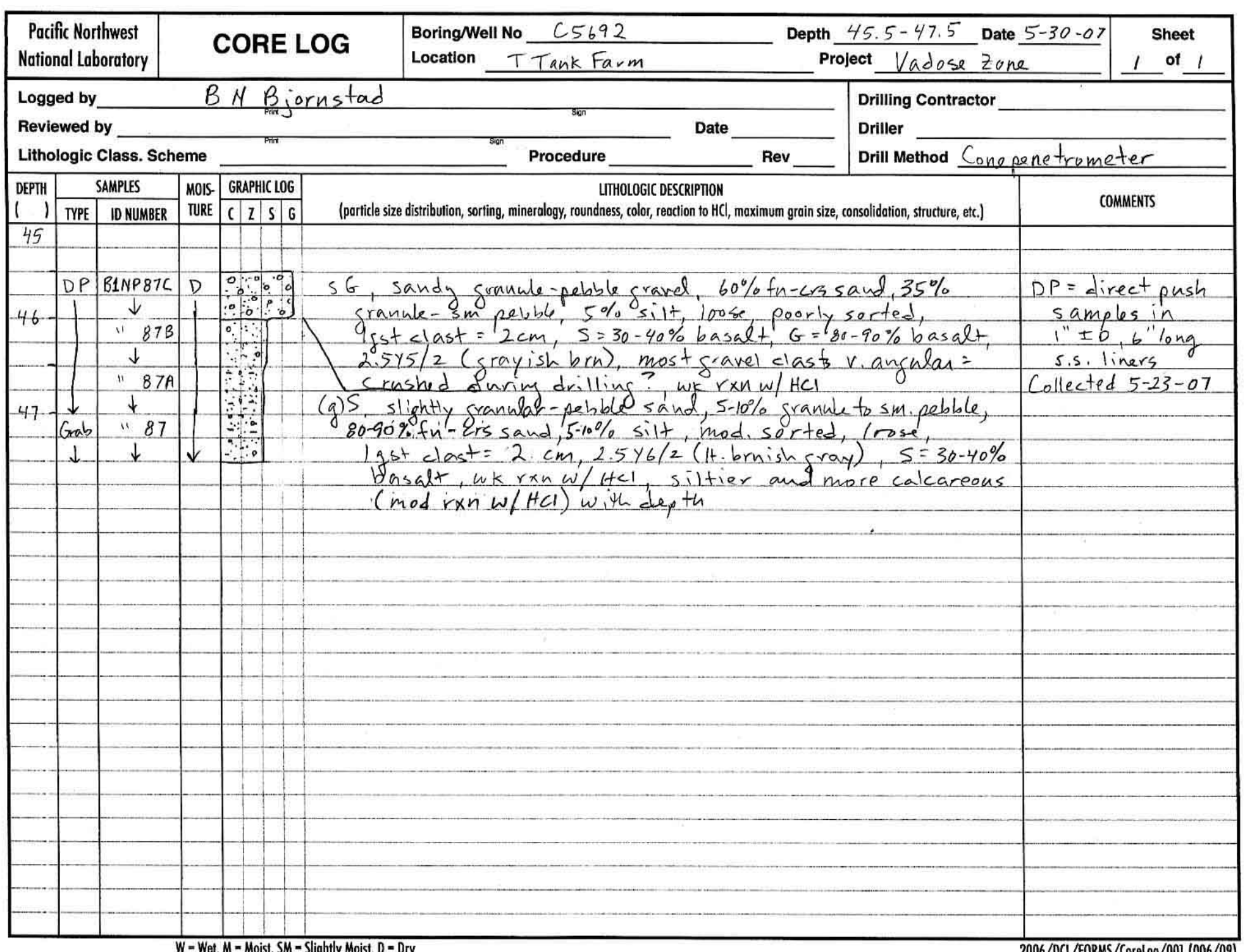

Figure F.1. Core Log for Direct-Push Vertical Borehole C5692 


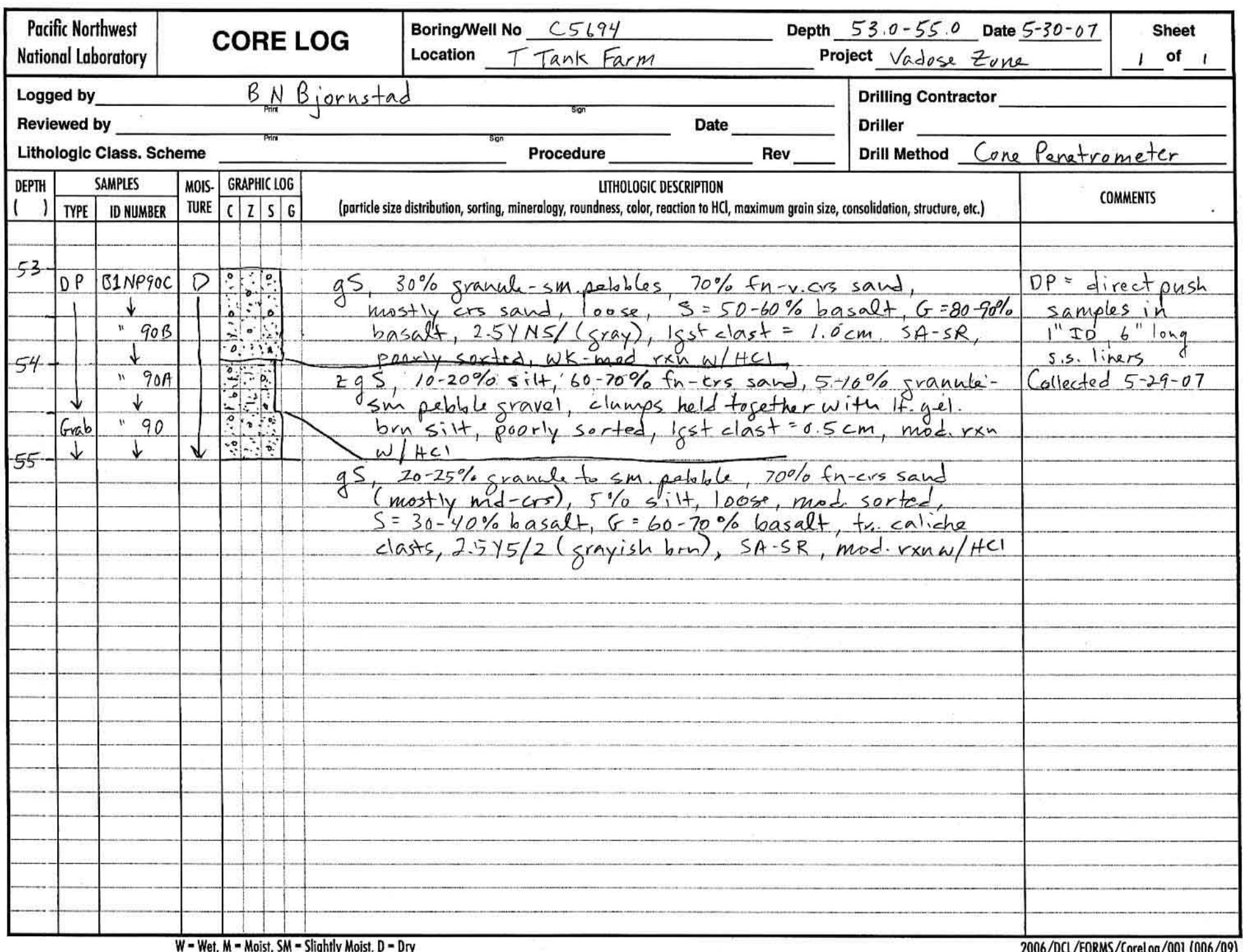

Figure F.2. Core Log for Direct-Push Vertical Borehole C5694 



\section{Distribution}

No. of

Copies

\section{OFFSITE}

Dr. Harry Babad

2540 Cordoba Court

Richland, WA 99352-1609

Dirk A. Dunning

Oregon Office of Energy

625 Marion Street NE

Salem, OR 97301-3742

Dr. Daniel I. Kaplan

Westinghouse Savannah River Company

Building 774-43A, Room 215

Aiken, SC 29808

Phil Reed

U.S. Nuclear Regulatory Commission

Office of Nuclear Regulatory Research

Division of Systems Analysis and

Regulatory Effectiveness

Radiation Protection, Environmental

Risk, and Waste Management Branch

Mail Stop: T9-F31

Washington, DC 20555-0001

Tom Stoops, LPG

Oregon Office of Energy

Nuclear Safety Division

625 Marion Street NE

Salem, OR 97303

Mr. Ronald G. Wilhelm

Office of Radiation and Indoor Air

401 M Street, S.W.

Mail Code 6603J

Washington, DC 20460
No. of

Copies

W. Alexander Williams

U.S. Department of Energy

Office of Environmental Restoration

EM-33

19901 Germantown Road

Germantown, MD 20874-1290

ONSITE

8 DOE Richland Operations Office
B. L. Foley
A6-38
J. P. Hanson
A5-13
R. D. Hildebrand
A6-38
K. A. Kapsi
A5-13
J. G. Morse
A6-38
K. M. Thompson
A6-38
DOE Public Reading Room (2) H2-53

\section{DOE Office of River Protection}
R. W. Lober
H6-60
S. A. Wiegman
H6-60

15 CH2M HILL Hanford Group, Inc.

$\begin{array}{lr}\text { R. Calmus } & \mathrm{S} 7-75 \\ \text { M. P. Connelly } & \mathrm{H} 6-03 \\ \text { J. G. Field } & \mathrm{H} 6-03 \\ \text { M. Jaraysi } & \mathrm{H} 6-03 \\ \text { J. G. Kristofzski } & \mathrm{H} 6-03 \\ \text { F. M. Mann (5) } & \mathrm{H} 6-03 \\ \text { W. J. McMahon } & \mathrm{H} 6-03 \\ \text { D. A. Myers } & \mathrm{H} 6-03 \\ \text { G. Parsons } & \mathrm{T} 6-04 \\ \text { H. A. Sydnor } & \mathrm{H} 6-03 \\ \text { D. J. Watson } & \mathrm{H} 6-03\end{array}$

\section{Fluor Federal Services}

R. Khaleel

E6-17 
No. of

Copies

12 Fluor Hanford, Inc.

M. W. Benecke

E6-44

T. W. Fogwell

E6-35

B. H. Ford

J. G. Hogan

D. G. Horton

S. M. Narbutovskih

V. J. Rohay

L. C. Swanson

G. S. Thomas

B. A. Williams

M. I. Wood

C. Wright

\section{S.M. Stoller}

R. G. McCain

B2-62

3 U.S. Environmental Protection Agency
N. Ceto
B1-46
D. A. Faulk
B1-46
R. Lobos
B1-46

\section{Washington State Department of Ecology}
S. Dahl-Crumpler
H0-57
J. A. Caggiano
H0-57
J.A. Hedges
H0-57
J. Lyon
$\mathrm{H} 0-57$
B. Rochette
H0-57
J. Yokel
$\mathrm{H} 0-57$
D. Goswami
H0-57

No. of

Copies

41 Pacific Northwest National Laboratory

S. R. Baum

P7-22

B. N. Bjornstad

K6-81

C. A. Brandt

K9-04

T. M. Brouns

K9-69

C. F. Brown (10)

P7-22

K. J. Cantrell

K6-81

E. T. Clayton

P7-22

W. J. Deutsch

K6-81

P. E. Dresel

K6-96

K. N. Geiszler

P7-22

M. J. Fayer

K9-33

M. D. Freshley

K9-33

J. S. Fruchter

K6-96

J. P. Icenhower

K6-81

C. Iovin

P7-22

J. M. Keller

BPO

K. M. Krupka

K6-81

I. V. Kutnyakov

P7-22

D. C. Lanigan

K6-75

G. V. Last

M. J. Lindberg

K6-81

$\mathrm{P} 7-22$

W. J. Martin

K6-81

C. J. Murray

K6-81

E. M. Pierce

K3-62

N. Qafoku

P7-54

R. J. Serne

$\mathrm{P} 7-22$

M. B. Triplett

K6-52

W. Um

$\mathrm{P} 7-22$

M. M. Valenta

P7-22

J. M. Zachara

K8-96

Hanford Technical Library (2)

P8-55 